\title{
Pd/Cu-Catalyzed Vinylation of Terminal Alkynes with (2-Bromoethyl)diphenylsulfonium Triflate
}

\author{
Xiao-Xia Ming, Shuai Wu, Ze-Yu Tian, Jia-Wei Song, Cheng-Pan Zhang* \\ School of Chemistry, Chemical Engineering and Life Science, Wuhan University of \\ Technology, Wuhan 430070, China. \\ E-mail: cpzhang@whut.edu.cn, zhangchengpan1982@hotmail.com.
}

\section{Table of contents}

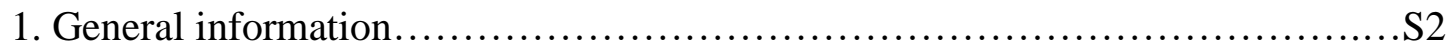

2. Screening of the optimal reaction conditions for vinylation of ethynylbenzene (1a)

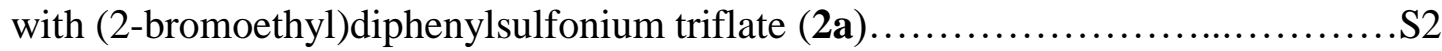

3. Screening of the optimal reaction conditions for vinylation of ethynylbenzene (1a)

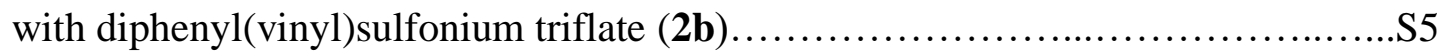

4. Procedures for the synthesis of (2-haloethyl)sulfonium salts, diphenyl(vinyl) sulfonium triflate, and (2-(tosyloxy)ethyl)sulfonium triflate....................S8

5. Procedures for the synthesis of terminal alkynes............................ 14

6. General procedures for vinylation of terminal alkyne (1) with (2-bromoethyl)

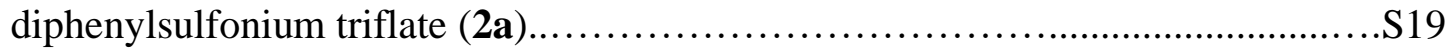

7. General procedures for vinylation of terminal alkyne (1) with diphenyl(vinyl)

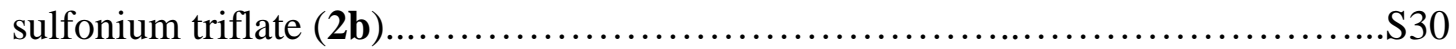

8. Vinylation of 1-ethynyl-4-nitrobenzene (1f) with $\mathbf{2 b}$ in the presence of different

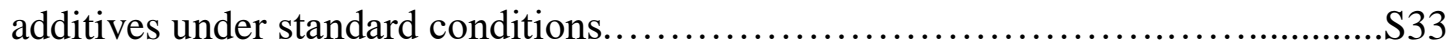

9. Reactions of different (2-haloethyl)sulfonium triflates or (2-(tosyloxy)ethyl) sulfonium triflate with $\mathrm{KHCO}_{3}$

10. ${ }^{1} \mathrm{H}$ NMR analysis of the reaction mixtures of (2-haloethyl)sulfonium triflates or (2-(tosyloxy)ethyl)sulfonium triflate with $\mathrm{K}_{3} \mathrm{PO}_{4}$ in THF- $d_{8}$ S42

11. NMR spectra of the products. .S48 


\section{General information.}

All reactions were carried out under a nitrogen atmosphere. Unless otherwise specified, NMR spectra were recorded in $\mathrm{CDCl}_{3}$ on a $500 \mathrm{MHz}$ (for ${ }^{1} \mathrm{H}$ ), $471 \mathrm{MHz}$ (for ${ }^{19} \mathrm{~F}$ ), and $126 \mathrm{MHz}$ (for ${ }^{13} \mathrm{C}$ ) spectrometer. All chemical shifts were reported in ppm relative to TMS (0 ppm for $\left.{ }^{1} \mathrm{H} \mathrm{NMR}\right)$ or $\mathrm{PhCF}_{3}$ (-63.5 ppm for ${ }^{19} \mathrm{~F} \mathrm{NMR}$ ) as an internal or external standard, respectively. The HPLC experiments were carried out on a Wufeng LC-100 II instrument (column: Shodex, C18, $5 \mu \mathrm{m}, 4.6 \times 250 \mathrm{~mm}$ ), and the yields of products were determined by using the corresponding pure compounds as the external standards, respectively. The coupling constants were reported in Hertz $(\mathrm{Hz})$. The following abbreviations were used to explain the multiplicities: $\mathrm{s}=$ singlet, $\mathrm{d}=$ doublet, $\mathrm{t}=$ triplet, $\mathrm{q}=$ quartet, $\mathrm{m}=$ multiplet, brs = broad singlet. Melting points were measured and uncorrected. MS experiments were performed on a TOF-Q ESI or EI instrument. (2-Fluoroethyl)diphenylsulfonium triflate (2c) was prepared according to the literature. ${ }^{1}$ The solvents were dried before use according to the literature. ${ }^{2}$ Other reagents in the reactions were all purchased from the commercial sources and used without further purification.

\section{Screening of the optimal reaction conditions for vinylation of ethynylbenzene}

(1a) with (2-bromoethyl)diphenylsulfonium triflates (2a).

Table S1. Vinylation of $\mathbf{1 a}$ with $\mathbf{2 a}$ in the presence of different $[\mathrm{Pd}] /[\mathrm{Cu}]$ catalysts. $^{a}$

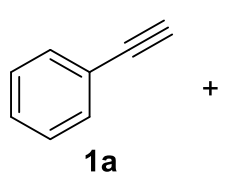

$1 \mathrm{a}$

$0.2 \mathrm{mmol}$

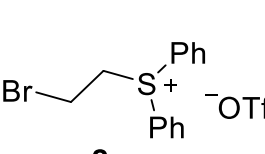

$2 \mathbf{a}$

$0.2 \mathrm{mmol}$

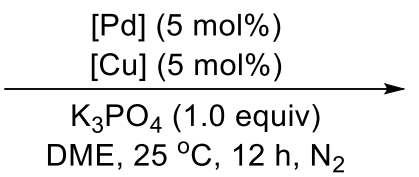

DME, $25^{\circ} \mathrm{C}, 12 \mathrm{~h}, \mathrm{~N}_{2}$

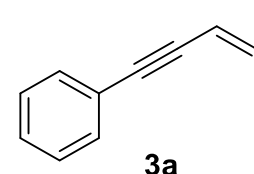

$3 a$

\begin{tabular}{cccc}
\hline Entry & {$[\mathrm{Pd}]$} & {$[\mathrm{Cu}]$} & Yield $(\mathbf{3 a}, \%)$ \\
\hline 1 & $\mathrm{Pd}_{2}(\mathrm{dba})_{3}$ & $\mathrm{CuI}$ & trace \\
2 & $\mathrm{Pd}(\mathrm{OAc})_{2}$ & $\mathrm{CuI}$ & trace \\
3 & $\mathrm{Pd}\left(\mathrm{PPh}_{3}\right)_{4}$ & $\mathrm{CuBr}$ & 29 \\
4 & $\mathrm{Pd}\left[\mathrm{P}(t-\mathrm{Bu})_{3}\right]_{2}$ & $\mathrm{CuI}$ & 4 \\
5 & $\mathrm{Pd}\left(\mathrm{PPh}_{3}\right)_{4}$ & $\mathrm{CuI}$ & 35 \\
6 & $\mathrm{Pd}\left(\mathrm{PPh}_{3}\right)_{4}$ & - & trace \\
7 & - & $\mathrm{CuI}$ & trace
\end{tabular}


${ }^{a}$ Reaction conditions: [Pd] (0.01 mmol), [Cu] (0.01 mmol), 1a $(0.2 \mathrm{mmol}), \mathbf{2 a}(0.2$ $\mathrm{mmol}), \mathrm{K}_{3} \mathrm{PO}_{4}(0.2 \mathrm{mmol}), \operatorname{DME}(2 \mathrm{~mL}), 25{ }^{\circ} \mathrm{C}, \mathrm{N}_{2}$, and $12 \mathrm{~h}$. The yields were determined by HPLC using 3a as an external standard $\left(\mathrm{t}_{\mathrm{R}}=4.890 \mathrm{~min}, \lambda_{\max }=267 \mathrm{~nm}\right.$, water / methanol $=20 / 80(\mathrm{v} / \mathrm{v}))$.

Table S2. $\mathrm{Pd}\left(\mathrm{PPh}_{3}\right)_{4} / \mathrm{CuI}$-Catalyzed vinylation of 1a with $\mathbf{2 a}$ in the presence of different bases. $^{a}$

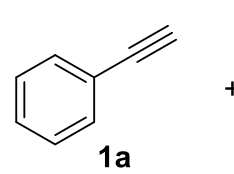

$0.2 \mathrm{mmol}$

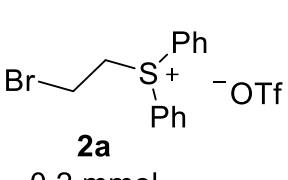

$0.2 \mathrm{mmol}$

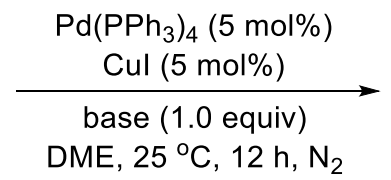

DME, $25^{\circ} \mathrm{C}, 12 \mathrm{~h}, \mathrm{~N}_{2}$

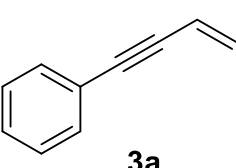

$3 a$

\begin{tabular}{ccc}
\hline Entry & Base & Yield (3a, \%) \\
\hline 1 & $\mathrm{NaHCO}_{3}$ & trace \\
2 & $\mathrm{~K}_{2} \mathrm{CO}_{3}$ & 56 \\
3 & $\mathrm{~K}_{3} \mathrm{PO}_{4}$ & 35 \\
4 & $\mathrm{Et}_{3} \mathrm{~N}$ & trace
\end{tabular}

${ }^{a}$ Reaction conditions: $\mathrm{Pd}\left(\mathrm{PPh}_{3}\right)_{4}(0.01 \mathrm{mmol}), \mathrm{CuI}(0.01 \mathrm{mmol}), \mathbf{1 a}(0.2 \mathrm{mmol}), \mathbf{2 a}$ (0.2 mmol), base $(0.2 \mathrm{mmol}), \mathrm{DME}(2 \mathrm{~mL}), 25{ }^{\circ} \mathrm{C}, \mathrm{N}_{2}$, and $12 \mathrm{~h}$. The yields were determined by HPLC using 3a as an external standard $\left(t_{R}=4.890 \min , \lambda_{\max }=267 \mathrm{~nm}\right.$, water / methanol $=20 / 80(\mathrm{v} / \mathrm{v}))$.

Table S3. The solvent effects on $\mathrm{Pd}\left(\mathrm{PPh}_{3}\right)_{4} / \mathrm{CuI}$-catalyzed vinylation of 1a with 2a in the presence of $\mathrm{K}_{2} \mathrm{CO}_{3}$ or $\mathrm{K}_{3} \mathrm{PO}_{4}{ }^{a}$

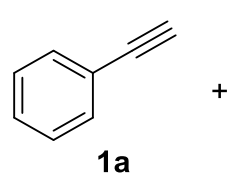

$0.2 \mathrm{mmol}$

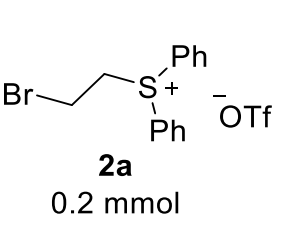

Base

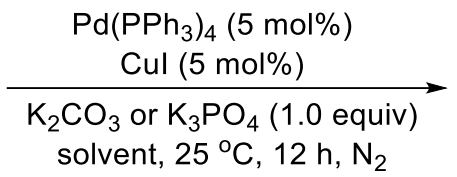

solvent, $25^{\circ} \mathrm{C}, 12 \mathrm{~h}, \mathrm{~N}_{2}$

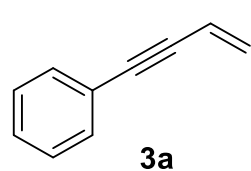

$3 a$

\begin{tabular}{cccc}
\hline Entry & Base & Solvent & Yield (3a, \%) \\
\hline 1 & $\mathrm{~K}_{3} \mathrm{PO}_{4}$ & DCM & 55 \\
2 & $\mathrm{~K}_{3} \mathrm{PO}_{4}$ & MeCN & 27 \\
3 & $\mathrm{~K}_{3} \mathrm{PO}_{4}$ & acetone & 50 \\
4 & $\mathrm{~K}_{3} \mathrm{PO}_{4}$ & THF & 52 \\
5 & $\mathrm{~K}_{3} \mathrm{PO}_{4}$ & DME & 35
\end{tabular}




$\begin{array}{cccc}6 & \mathrm{~K}_{2} \mathrm{CO}_{3} & \text { DME } & 56,70^{b} \\ 7 & \mathrm{~K}_{2} \mathrm{CO}_{3} & \text { DCM } & 17 \\ 8 & \mathrm{~K}_{2} \mathrm{CO}_{3} & \text { THF } & 37 \\ 9 & \mathrm{~K}_{2} \mathrm{CO}_{3} & \text { acetone } & 48\end{array}$

${ }^{a}$ Reaction conditions: $\mathrm{Pd}\left(\mathrm{PPh}_{3}\right)_{4}(0.01 \mathrm{mmol}), \mathrm{CuI}(0.01 \mathrm{mmol}), \mathbf{1 a}(0.2 \mathrm{mmol}), \mathbf{2 a}$ (0.2 mmol), $\mathrm{K}_{2} \mathrm{CO}_{3}$ or $\mathrm{K}_{3} \mathrm{PO}_{4}(0.2 \mathrm{mmol})$, solvent $(2 \mathrm{~mL}), 25{ }^{\circ} \mathrm{C}, \mathrm{N}_{2}$, and $12 \mathrm{~h}$. The yields were determined by HPLC using 3a as an external standard $\left(t_{R}=4.890 \mathrm{~min}\right.$, $\lambda_{\max }=267 \mathrm{~nm}$, water $/$ methanol $\left.=20 / 80(\mathrm{v} / \mathrm{v})\right) . \quad{ }^{b} \mathbf{1 a}(0.2 \mathrm{mmol}), \mathbf{2 a}(0.3 \mathrm{mmol})$, $\mathrm{K}_{2} \mathrm{CO}_{3}(0.3 \mathrm{mmol})$.

Table S4. $\mathrm{Pd}\left(\mathrm{PPh}_{3}\right)_{4} / \mathrm{CuI}-$ Catalyzed vinylation of $\mathbf{1 a}$ with $\mathbf{2 a}$ in different solvents and with different reactant ratios. ${ }^{a}$

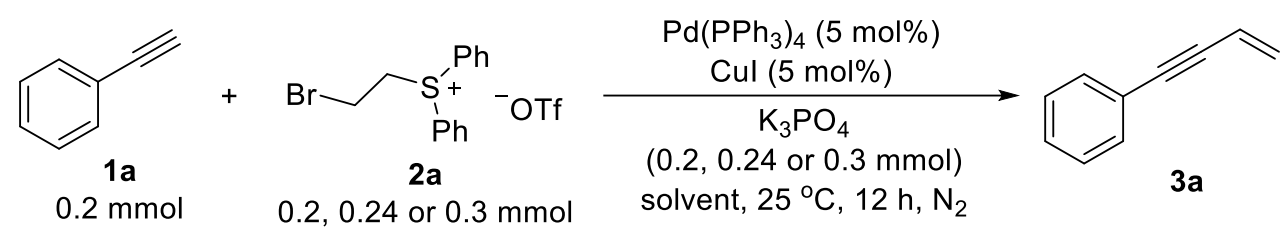

\begin{tabular}{cccc}
\hline Entry & Solvent & $\mathbf{1 a}: \mathbf{2 a}: \mathrm{K}_{3} \mathrm{PO}_{4}$ & Yield (3a, \%) \\
\hline 1 & DCM & $1: 1: 1$ & 55 \\
2 & acetone & $1: 1: 1$ & 50 \\
3 & THF & $1: 1: 1$ & 52 \\
4 & DME & $1: 1: 1$ & 35 \\
5 & DME & $1: 1: 1$ & $56^{b}$ \\
6 & DME & $1: 1.2: 1.2$ & 57 \\
7 & DME & $1: 1.5: 1.5$ & $74(48)$ \\
8 & THF & $1: 1.5: 1.5$ & 81 \\
9 & DCM & $1: 1.5: 1.5$ & 49 \\
10 & acetone & $1: 1.5: 1.5$ & 75 \\
11 & DME & $1: 1.5: 1.5$ & $70^{b}$ \\
\hline
\end{tabular}

${ }^{a}$ Reaction conditions: $\mathrm{Pd}\left(\mathrm{PPh}_{3}\right)_{4}(0.01 \mathrm{mmol}), \mathrm{CuI}(0.01 \mathrm{mmol}), \mathbf{1 a}(0.2 \mathrm{mmol}), \mathbf{2 a}$ (0.2, 0.24, or $0.3 \mathrm{mmol}), \mathrm{K}_{3} \mathrm{PO}_{4}(0.2,0.24$, or $0.3 \mathrm{mmol})$, solvent $(2 \mathrm{~mL}), 25{ }^{\circ} \mathrm{C}, \mathrm{N}_{2}$, and $12 \mathrm{~h}$. The yields were determined by HPLC using 3a as an external standard $\left(\mathrm{t}_{\mathrm{R}}=\right.$ $4.890 \mathrm{~min}, \lambda_{\max }=267 \mathrm{~nm}$, water $/$ methanol $=20 / 80(\mathrm{v} / \mathrm{v})$ ). Isolated yield was 
depicted in the parenthesis (The product is volatile and easily evaporated under reduced pressure during removal of the solvents). $\quad{ }^{b}$ Using $\mathrm{K}_{2} \mathrm{CO}_{3}$ as a base.

Table S5. $\mathrm{Pd}\left(\mathrm{PPh}_{3}\right)_{4} / \mathrm{CuI}-\mathrm{Catalyzed}$ vinylation of 1a with 2a in DME or THF at different temperatures and with different reaction times. ${ }^{a}$

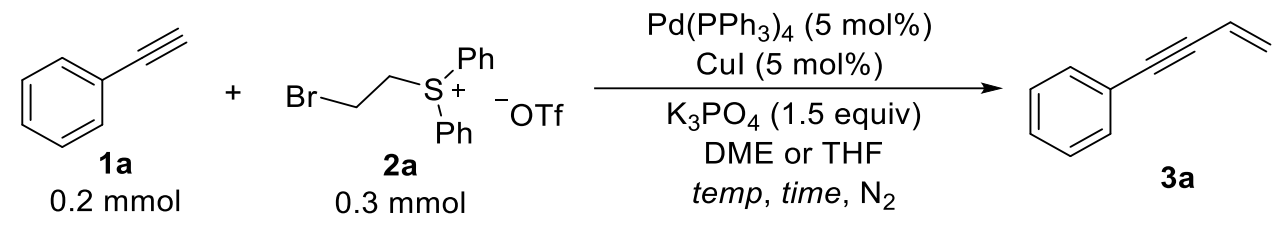

\begin{tabular}{ccccc}
\hline Entry & Solvent & Temp $\left({ }^{\circ} \mathrm{C}\right)$ & Time $(\mathrm{h})$ & Yield $(\mathbf{3 a}, \%)$ \\
\hline 1 & DME & 0 & 12 & trace \\
2 & DME & 25 & 6 & 43 \\
3 & DME & 25 & 12 & 74 \\
4 & DME & 25 & 24 & 64 \\
5 & DME & 40 & 12 & 73 \\
6 & DME & 40 & 24 & 70 \\
7 & THF & 25 & 12 & 81 \\
8 & THF & 25 & 24 & 82
\end{tabular}

${ }^{a}$ Reaction conditions: $\mathrm{Pd}\left(\mathrm{PPh}_{3}\right)_{4}(0.01 \mathrm{mmol}), \mathrm{CuI}(0.01 \mathrm{mmol}), \mathbf{1 a}(0.2 \mathrm{mmol}), \mathbf{2 a}$ (0.3 mmol), $\mathrm{K}_{3} \mathrm{PO}_{4}(0.3 \mathrm{mmol})$, and DME or THF $(2 \mathrm{~mL})$ at different temperatures under $\mathrm{N}_{2}$ for 6-24 h. The yields were determined by HPLC using 3a as an external standard $\left(\mathrm{t}_{\mathrm{R}}=4.890 \mathrm{~min}, \lambda_{\max }=267 \mathrm{~nm}\right.$, water $/$ methanol $\left.=20 / 80(\mathrm{v} / \mathrm{v})\right)$.

\section{Screening of the optimal reaction conditions for vinylation of ethynylbenzene} (1a) with diphenyl(vinyl)sulfonium triflate (2b).

Table S6. The solvent effects on $\mathrm{Pd}\left(\mathrm{PPh}_{3}\right)_{4} / \mathrm{CuI}$-catalyzed vinylation of $\mathbf{1 a}$ with $\mathbf{2 b}$ at room temperature. ${ }^{a}$

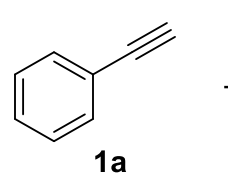

$0.2 \mathrm{mmol}$

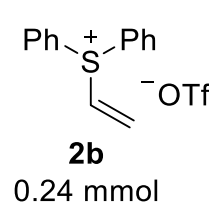

$0.24 \mathrm{mmol}$

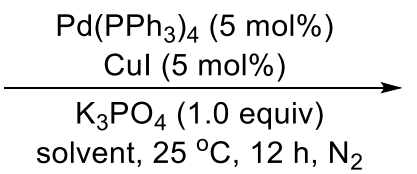

solvent, $25^{\circ} \mathrm{C}, 12 \mathrm{~h}, \mathrm{~N}_{2}$<smiles>C=CC#Cc1ccccc1</smiles> 


\begin{tabular}{ccc}
\hline Entry & Solvent & Yield (3a, \%) \\
\hline 1 & DME & 99 \\
2 & THF & 96 \\
3 & DMSO & 82 \\
4 & $1,4-$ dioxane & 77 \\
5 & MeCN & 38 \\
6 & DCM & 45 \\
7 & DCE & 59
\end{tabular}

${ }^{a}$ Reaction conditions: $\mathrm{Pd}\left(\mathrm{PPh}_{3}\right)_{4}(0.01 \mathrm{mmol}), \mathrm{CuI}(0.01 \mathrm{mmol}), \mathbf{1 a}(0.2 \mathrm{mmol}), \mathbf{2 b}$ (0.24 mmol), $\mathrm{K}_{3} \mathrm{PO}_{4}(0.2 \mathrm{mmol})$, solvent $(2 \mathrm{~mL}), 25{ }^{\circ} \mathrm{C}, \mathrm{N}_{2}$, and $12 \mathrm{~h}$. The yields were determined by HPLC using 3a as an external standard $\left(t_{R}=4.890 \min , \lambda_{\max }=267 \mathrm{~nm}\right.$, water / methanol $=20 / 80(\mathrm{v} / \mathrm{v}))$.

Table S7. $\mathrm{Pd}\left(\mathrm{PPh}_{3}\right)_{4} / \mathrm{CuI}$-Catalyzed vinylation of $\mathbf{1 a}$ with $\mathbf{2} \mathbf{b}$ in the presence of

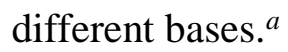

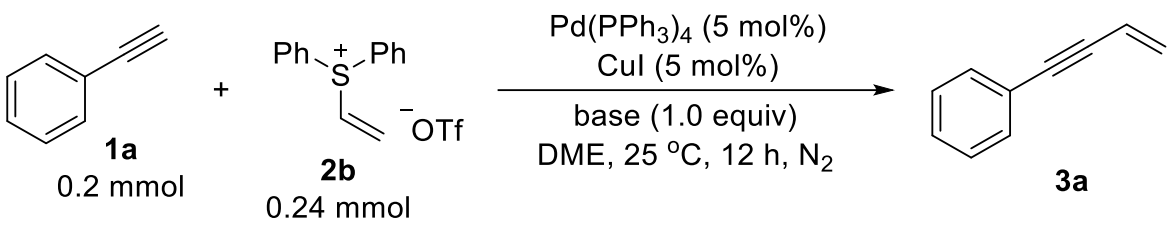

\begin{tabular}{ccc}
\hline Entry & Base & Yield (3a, \%) \\
\hline 1 & $\mathrm{~K}_{3} \mathrm{PO}_{4}$ & 99 \\
2 & $\mathrm{Na}_{2} \mathrm{CO}_{3}$ & 85 \\
3 & $\mathrm{Cs}_{2} \mathrm{CO}_{3}$ & 25 \\
4 & $\mathrm{NaHCO}_{3}$ & 20 \\
5 & $\mathrm{~K}_{2} \mathrm{CO}_{3}$ & 92 \\
6 & $\mathrm{~K}_{2} \mathrm{HPO}_{4}$ & 26 \\
7 & $\mathrm{Et}_{3} \mathrm{~N}$ & 74 \\
8 & $\mathrm{DBU}$ & 6
\end{tabular}

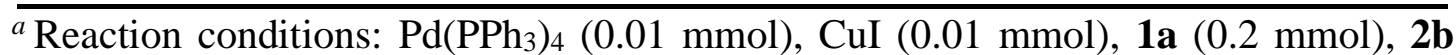
(0.24 mmol), base (0.2 mmol), DME $(2 \mathrm{~mL}), 25{ }^{\circ} \mathrm{C}, \mathrm{N}_{2}$, and $12 \mathrm{~h}$. The yields were determined by HPLC using 3a as an external standard $\left(t_{R}=4.890 \min , \lambda_{\max }=267 \mathrm{~nm}\right.$, water / methanol $=20 / 80(\mathrm{v} / \mathrm{v}))$. 
Table S8. $\mathrm{Pd}\left(\mathrm{PPh}_{3}\right)_{4} / \mathrm{CuI}-\mathrm{Catalyzed}$ vinylation of $\mathbf{1 a}$ with $\mathbf{2 b}$ in the presence of different $[\mathrm{Pd}] /[\mathrm{Cu}]$ catalysts. $^{a}$

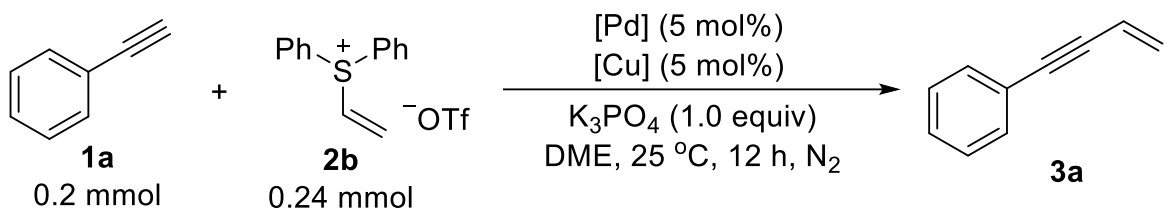

\begin{tabular}{cccc}
\hline Entry & {$[\mathrm{Pd}]$} & {$[\mathrm{Cu}]$} & Yield $(\mathbf{3 a}, \%)$ \\
\hline 1 & $\mathrm{Pd}\left(\mathrm{PPh}_{3}\right)_{4}$ & $\mathrm{CuI}$ & 99 \\
2 & $\mathrm{Pd}_{2}(\mathrm{dba})_{3}$ & $\mathrm{CuI}$ & $<1$ \\
3 & $\mathrm{Pd}\left[\mathrm{P}(\mathrm{t}-\mathrm{Bu})_{3}\right]_{2}$ & $\mathrm{CuI}$ & 66 \\
4 & $\mathrm{Pd}(\mathrm{OAc})_{2}$ & $\mathrm{CuI}$ & 19 \\
5 & $\mathrm{Pd}\left(\mathrm{PPh}_{3}\right)_{2} \mathrm{Cl}_{2}$ & $\mathrm{CuI}$ & 18 \\
6 & $\mathrm{PdCl}_{2}$ & $\mathrm{CuI}$ & 2 \\
7 & $\mathrm{Pd}_{2}\left(\mathrm{PPh}_{3}\right)_{4}$ & $\mathrm{CuBr}$ & 73 \\
8 & $\mathrm{Pd}_{\left(\mathrm{PPh}_{3}\right)_{4}}$ & $\mathrm{CuBr} 2$ & 56 \\
9 & $\mathrm{Pd}_{2}\left(\mathrm{PPh}_{3}\right)_{4}$ & $\mathrm{CuCl}$ & 47
\end{tabular}

${ }^{a}$ Reaction conditions: [Pd] $(0.01 \mathrm{mmol}),[\mathrm{Cu}](0.01 \mathrm{mmol}), \mathbf{1 a}(0.2 \mathrm{mmol}), \mathbf{2 b}(0.24$ $\mathrm{mmol}), \mathrm{K}_{3} \mathrm{PO}_{4}(0.2 \mathrm{mmol}), \mathrm{DME}(2 \mathrm{~mL}), 25{ }^{\circ} \mathrm{C}, \mathrm{N}_{2}$, and $12 \mathrm{~h}$. The yields were determined by HPLC using 3a as an external standard $\left(t_{R}=4.890 \min , \lambda_{\max }=267 \mathrm{~nm}\right.$, water / methanol $=20 / 80(\mathrm{v} / \mathrm{v}))$.

Table S9. $\mathrm{Pd}\left(\mathrm{PPh}_{3}\right)_{4} / \mathrm{CuI}$-Catalyzed vinylation of $\mathbf{1 a}$ with $\mathbf{2 b}$ in DME at different temperatures and with different reaction times. ${ }^{a}$

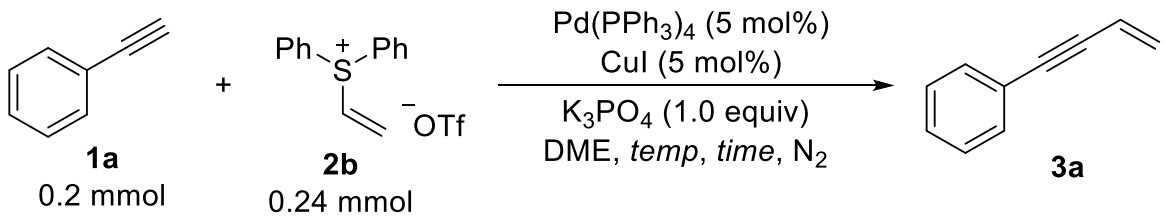

\begin{tabular}{cccc}
\hline Entry & $\operatorname{Temp}\left({ }^{\circ} \mathrm{C}\right)$ & Time $(\mathrm{h})$ & Yield $(\mathbf{3 a}, \%)$ \\
\hline 1 & 22 & 3 & 38 \\
2 & 22 & 6 & 60 \\
3 & 22 & 9 & 83 \\
4 & 22 & 12 & 84
\end{tabular}




$\begin{array}{cccc}5 & 22 & 24 & 85 \\ 6 & 25 & 6 & 68 \\ 7 & 25 & 9 & 75 \\ 8 & 25 & 12 & 99 \\ 9 & 25 & 24 & 99 \\ 10 & 30 & 3 & 76 \\ 11 & 30 & 6 & 99\end{array}$

${ }^{a}$ Reaction conditions: $\mathrm{Pd}\left(\mathrm{PPh}_{3}\right)_{4}(0.01 \mathrm{mmol})$, CuI $(0.01 \mathrm{mmol}), \mathbf{1 a}(0.2 \mathrm{mmol}), \mathbf{2 b}$ $(0.24 \mathrm{mmol}), \mathrm{K}_{3} \mathrm{PO}_{4}(0.2 \mathrm{mmol})$, and DME $(2 \mathrm{~mL})$ at 22,25 , or $30{ }^{\circ} \mathrm{C}$ under $\mathrm{N}_{2}$ for 3-24 $\mathrm{h}$. The yields were determined by HPLC using 3a as an external standard $\left(\mathrm{t}_{\mathrm{R}}=\right.$ $4.890 \mathrm{~min}, \lambda_{\max }=267 \mathrm{~nm}$, water $/$ methanol $=20 / 80(\mathrm{v} / \mathrm{v})$ ).

\section{Procedures for the synthesis of (2-haloethyl)sulfonium salts, diphenyl(vinyl) sulfonium triflate, and (2-(tosyloxy)ethyl)sulfonium triflate.}

\subsection{Procedures for the synthesis of $2 a$ and $2 b .^{3}$}

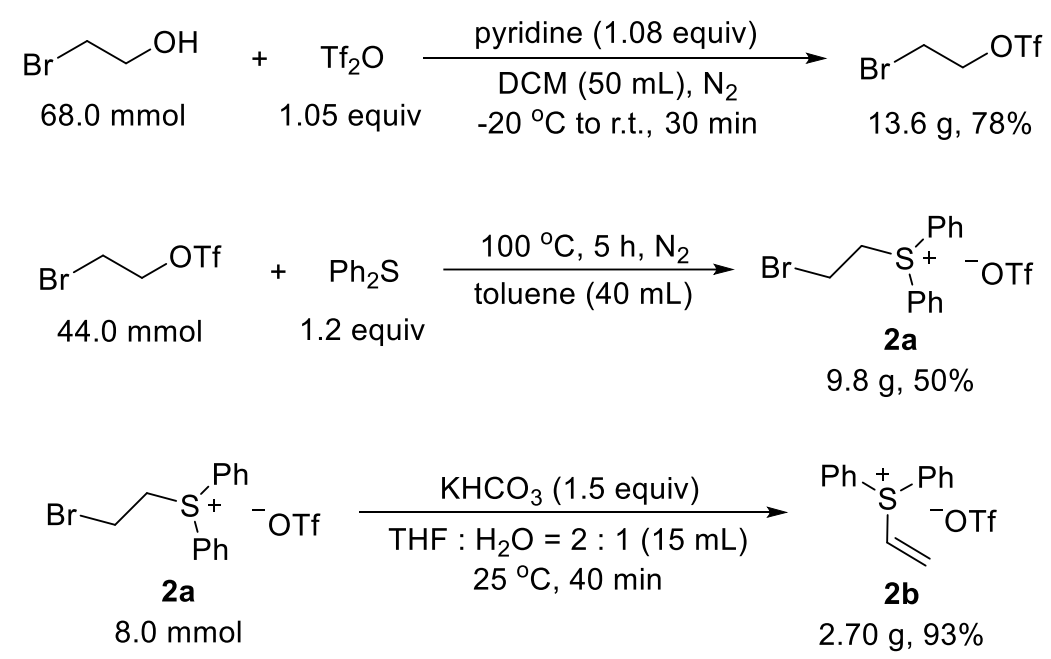

Step 1: Under a nitrogen atmosphere, $\mathrm{Tf}_{2} \mathrm{O}(11.9 \mathrm{~mL}, 70.8 \mathrm{mmol})$ was added dropwise to a solution of pyridine $(5.82 \mathrm{~g}, 73.6 \mathrm{mmol})$ in dry DCM $(50 \mathrm{~mL})$ at $-20{ }^{\circ} \mathrm{C}$ with vigorous stirring. After 10 minutes, 2-bromoethanol $(8.50 \mathrm{~g}, 68.0 \mathrm{mmol})$ was added dropwise to the mixture. The cooling bath was removed and the mixture was reacted for another 20 minutes. The resulting suspension was concentrated under reduced pressure and diluted with DCM/hexane $(1 / 1(\mathrm{v} / \mathrm{v}), 40 \mathrm{~mL})$. The suspension was filtered through a silica gel pad $(5 \mathrm{~cm}$ length) on a column using DCM/hexane 
$(1 / 1, \mathrm{v} / \mathrm{v})$ as eluents to afford 2-bromoethyl trifluoromethanesulfonate (13.6 g, 78\%) as a light brown oil.

Step 2: A heavy-walled pressure tube $(100 \mathrm{~mL})$ with a teflon screwcap was charged with 2-bromoethyl trifluoromethanesulfonate (11.3 g, $44.0 \mathrm{mmol})$, diphenylsulfane $(9.82 \mathrm{~g}, 52.8 \mathrm{mmol})$ and toluene $(40 \mathrm{~mL})$ with vigorous stirring. The tube was sealed and immersed in an oil bath at $100{ }^{\circ} \mathrm{C}$ for $5 \mathrm{~h}$. The reaction mixture was cooled to room temperature and concentrated to ca. $7 \mathrm{~mL}$ under reduced pressure. Diethyl ether $(60 \mathrm{~mL})$ was added to the mixture for crystallization. The precipitates were filtered, washed with diethyl ether $(3 \times 2 \mathrm{~mL})$, and dried in vacuum to afford (2-bromoethyl) diphenylsulfonium triflate (2a) as a white solid (9.8 g, 50\%). M.p.: 86.1-87.4 ${ }^{\circ} \mathrm{C} .{ }^{1} \mathrm{H}$ NMR $\left(500 \mathrm{MHz}, \mathrm{CDCl}_{3}\right) \delta 8.09(\mathrm{~d}, J=7.8 \mathrm{~Hz}, 4 \mathrm{H}), 7.76(\mathrm{t}, J=6.9 \mathrm{~Hz}, 2 \mathrm{H}), 7.70(\mathrm{t}, J$ $=7.2 \mathrm{~Hz}, 4 \mathrm{H}), 4.84(\mathrm{t}, J=5.6 \mathrm{~Hz}, 2 \mathrm{H}), 3.67(\mathrm{t}, J=5.7 \mathrm{~Hz}, 2 \mathrm{H}) .{ }^{19} \mathrm{~F} \mathrm{NMR}(471 \mathrm{MHz}$, $\left.\mathrm{CDCl}_{3}\right) \delta-78.2(\mathrm{~s}, 3 \mathrm{~F}) .{ }^{13} \mathrm{C} \mathrm{NMR}\left(126 \mathrm{MHz}, \mathrm{CDCl}_{3}\right) \delta$ 135.2, 131.8, 131.1, 123.0, $120.8(\mathrm{q}, J=320.1 \mathrm{~Hz}), 48.1,23.7$.

Step 3: To a solution of (2-bromoethyl)diphenylsulfonium triflate (3.55 g, $8.0 \mathrm{mmol})$ in $\mathrm{THF} / \mathrm{H}_{2} \mathrm{O}(2 / 1(\mathrm{v} / \mathrm{v}), 15 \mathrm{~mL})$ was added $\mathrm{KHCO}_{3}(1.20 \mathrm{~g}, 12.0 \mathrm{mmol})$ with stirring. The mixture was reacted at $25{ }^{\circ} \mathrm{C}$ for $40 \mathrm{~min}$, dried over anhydrous $\mathrm{Na}_{2} \mathrm{SO}_{4}$ and concentrated to ca. $2 \mathrm{~mL}$ under reduced pressure (Note: for a larger scale (e.g., 22.0 mmol) the mixture was reacted at $25{ }^{\circ} \mathrm{C}$ for $40 \mathrm{~min}$ and $\mathrm{CH}_{2} \mathrm{Cl}_{2}(30 \mathrm{~mL}) / \mathrm{H}_{2} \mathrm{O}(10 \mathrm{~mL})$ was added. The organic layer was collected, dried over anhydrous $\mathrm{Na}_{2} \mathrm{SO}_{4}$, and concentrated to ca. $3 \mathrm{~mL}$ under reduced pressure). The residue was purified by flash column chromatography on silica gel using a mixture of DCM / $\mathrm{MeCN}=3 / 1$ (v / v) as eluents to give diphenyl(vinyl) sulfonium triflate (2b) as a light yellow oil (2.70 g, 93\%). ${ }^{1} \mathrm{H}$ NMR $\left(500 \mathrm{MHz}, \mathrm{CDCl}_{3}\right) \delta 7.86(\mathrm{~d}, J=8.0 \mathrm{~Hz}, 4 \mathrm{H}), 7.70(\mathrm{t}, J=7.5 \mathrm{~Hz}, 2 \mathrm{H})$, $7.64(\mathrm{t}, J=7.6 \mathrm{~Hz}, 4 \mathrm{H}), 7.47(\mathrm{dd}, J=16.0 \mathrm{~Hz}, 8.9 \mathrm{~Hz}, 1 \mathrm{H}), 6.66(\mathrm{dm}, J=8.8 \mathrm{~Hz}, 1 \mathrm{H})$, $6.52(\mathrm{dm}, J=16.0 \mathrm{~Hz}, 1 \mathrm{H}) .{ }^{19} \mathrm{~F}$ NMR $\left(471 \mathrm{MHz}, \mathrm{CDCl}_{3}\right) \delta-78.2(\mathrm{~s}, 3 \mathrm{~F}) .{ }^{13} \mathrm{C}$ NMR $\left(126 \mathrm{MHz} \mathrm{CDCl}_{3}\right) \delta 137.1,133.6,130.6,129.5,124.2,122.1,119.9$ (q, $J=320.8$ $\mathrm{Hz})$.

\subsection{Typical procedure for the synthesis of $2 \mathrm{~d}-\mathrm{g} .{ }^{4}$}

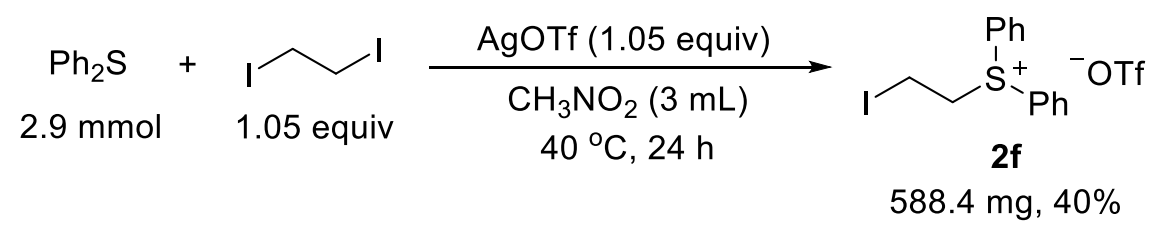


Taking (2-iodoethyl)diphenylsulfonium triflate (2f) as an example: Under a nitrogen atmosphere, an oven dried Schlenk tube $(15 \mathrm{~mL})$ covered with Tin foil was charged with diphenylsulfane $(532.3 \mathrm{mg}, 2.9 \mathrm{mmol}), 1,2$-diiodoethane $(845.7 \mathrm{mg}, 3.0 \mathrm{mmol})$, silver trifluoromethanesulfonate $(770.7 \mathrm{mg}, 3.0 \mathrm{mmol})$, and nitromethane $(3 \mathrm{~mL})$ with vigorous stirring. The mixture was reacted at $40{ }^{\circ} \mathrm{C}$ for $24 \mathrm{~h}$, cooled to room temperature, and filtered through a pad of Celite $(2 \mathrm{~cm})$ using DCM $(70 \mathrm{~mL})$ as eluent. The solution (filtrate) was concentrated to ca. $2 \mathrm{~mL}$ under reduced pressure. Then, the crude product was purified by crystallization from DCM $(1.5 \mathrm{~mL}) /$ diethyl ether $(30$ $\mathrm{mL}$ ) system to afford (2-iodoethyl)diphenylsulfonium triflate (2f) as a white solid (588.4 mg, 40\%). M.p.: 99.1-100.2 ${ }^{\circ} \mathrm{C} .{ }^{1} \mathrm{H}$ NMR $\left(500 \mathrm{MHz}, \mathrm{CDCl}_{3}\right) \delta 8.09$ (d, J=7.9 $\mathrm{Hz}, 4 \mathrm{H}), 7.77$ (t, $J=7.5 \mathrm{~Hz}, 2 \mathrm{H}), 7.72(\mathrm{t}, J=7.8 \mathrm{~Hz}, 4 \mathrm{H}), 4.82(\mathrm{t}, J=6.5 \mathrm{~Hz}, 2 \mathrm{H})$, $3.42(\mathrm{t}, J=6.5 \mathrm{~Hz}, 2 \mathrm{H}) .{ }^{19} \mathrm{~F} \mathrm{NMR}\left(471 \mathrm{MHz}, \mathrm{CDCl}_{3}\right) \delta-78.2(\mathrm{~s}, 3 \mathrm{~F}) .{ }^{13} \mathrm{C}$ NMR $(126$ $\left.\mathrm{MHz}, \mathrm{CDCl}_{3}\right) \delta 135.8$ (assigned to impurity), 135.2, 131.9, 131.0 (assigned to impurity), 131.0, 129.2 (assigned to impurity), 127.1 (assigned to impurity), 122.9, $120.5(\mathrm{q}, J=319.2 \mathrm{~Hz}), 48.6,-7.3$ (2f decomposed during the ${ }^{13} \mathrm{C} \mathrm{NMR}$ measurement). IR (KBr): 3064, 2979, 2930, 1580, 1481, 1450, 1419, 1277, 1249, 1154, 1028, 908, 810, 750, 685, $636 \mathrm{~cm}^{-1}$. HRMS-ESI $(\mathrm{m} / \mathrm{z})$ calcd. for $\left[\mathrm{C}_{14} \mathrm{H}_{14} \mathrm{IS}\right]^{+}$ $\left([\mathrm{M}]^{+}\right): 340.9856$; found: 340.9862 .

\section{(2-Chloroethyl)diphenylsulfonium triflate (2d)}<smiles>[O-][Sb](c1ccccc1)[S+](P)CCCl</smiles>

White solid (238.6 mg, 31\%), from diphenylsulfane (354.0 mg, $1.9 \mathrm{mmol}$ ), 1-chloro-2-iodoethane $(380.8 \mathrm{mg}, 2.0 \mathrm{mmol})$, and silver trifluoromethanesulfonate $(513.8 \mathrm{mg}, 2.0 \mathrm{mmol})$. The crude product was purified by crystallization three times from DCM (1.5 mL)/ diethyl ether $(1.5 \mathrm{~mL})$ system at $-18{ }^{\circ} \mathrm{C}$. M.p.: 89.6-90.8 ${ }^{\circ} \mathrm{C} .{ }^{1} \mathrm{H}$ NMR (500 MHz, $\left.\mathrm{CDCl}_{3}\right) \delta 8.09(\mathrm{~d}, J=7.8 \mathrm{~Hz}, 4 \mathrm{H}), 7.78(\mathrm{t}, J=7.4 \mathrm{~Hz}, 2 \mathrm{H}), 7.72(\mathrm{t}, J$ $=7.7 \mathrm{~Hz}, 4 \mathrm{H}), 4.79(\mathrm{t}, J=6.6 \mathrm{~Hz}, 2 \mathrm{H}), 3.41(\mathrm{t}, J=6.6 \mathrm{~Hz}, 2 \mathrm{H}) .{ }^{19} \mathrm{~F} \mathrm{NMR}(471 \mathrm{MHz}$, $\left.\mathrm{CDCl}_{3}\right) \delta-78.2$ (s, 3F). ${ }^{13} \mathrm{C} \mathrm{NMR}\left(126 \mathrm{MHz}, \mathrm{CDCl}_{3}\right) \delta 135.8$ (assigned to impurity), 135.3 (assigned to impurity), 135.2, 131.9, 131.0 (assigned to impurity), 131.0, 129.2 (assigned to impurity), 127.1 (assigned to impurity), 122.9 (assigned to impurity), $122.9,120.5(\mathrm{q}, J=320.1 \mathrm{~Hz}), 48.6,37.6$ (2d decomposed during the ${ }^{13} \mathrm{C} \mathrm{NMR}$ measurement). IR (KBr): 3092, 3024, 2994, 2947, 1579, 1475, 1445, 1286, 1182, 
1048, 1036, 997, 765, 749, $688 \mathrm{~cm}^{-1}$. HRMS-ESI $(\mathrm{m} / \mathrm{z})$ calcd. for $\left[\mathrm{C}_{14} \mathrm{H}_{14} \mathrm{ClS}\right]^{+}\left([\mathrm{M}]^{+}\right)$: 249.0500; found: 249.0503 .

\section{(2-Chloroethyl)diphenylsulfonium tetrafluoroborate (2e)}

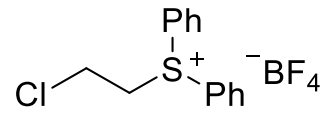

Yellowish brown solid (344.3 mg, 42\%), from diphenylsulfane (354.0 mg, $1.9 \mathrm{mmol}$ ), 1-chloro-2-iodoethane $(380.8 \mathrm{mg}, 2.0 \mathrm{mmol})$, and silver tetrafluoroborate $(389.3 \mathrm{mg}$, 2.0 mmol). M.p.: 104.5-105.6 ${ }^{\circ} \mathrm{C} .{ }^{1} \mathrm{H}$ NMR $\left(500 \mathrm{MHz}, \mathrm{CDCl}_{3}\right) \delta 8.03(\mathrm{~d}, J=7.7 \mathrm{~Hz}$, 4H), $7.77(\mathrm{t}, J=7.3 \mathrm{~Hz}, 2 \mathrm{H}), 7.71(\mathrm{t}, J=7.7 \mathrm{~Hz}, 4 \mathrm{H}), 4.68(\mathrm{t}, J=6.6 \mathrm{~Hz}, 2 \mathrm{H}), 3.42(\mathrm{t}$, $J=6.6 \mathrm{~Hz}, 2 \mathrm{H}) .{ }^{19} \mathrm{~F}$ NMR $\left(471 \mathrm{MHz}, \mathrm{CDCl}_{3}\right) \delta-150.9 \mathrm{~Hz}$ to $-151.0 \mathrm{~Hz}(4 \mathrm{~F}) .{ }^{13} \mathrm{C}$ NMR (126 MHz, $\mathrm{CDCl}_{3}$ ) $\delta$ 135.2, 131.9, 131.0 (assigned to impurity), 130.9, 130.9 (assigned to impurity), 129.2 (assigned to impurity), 127.1 (assigned to impurity), 122.9, 48.3, 37.6. (2e decomposed during the ${ }^{13} \mathrm{C}$ NMR measurement). HRMS-ESI $(\mathrm{m} / \mathrm{z})$ calcd. for $\left[\mathrm{C}_{14} \mathrm{H}_{14} \mathrm{ClS}\right]^{+}\left([\mathrm{M}]^{+}\right): 249.0500$; found: 249.0493 .

\section{(2-Iodoethyl)diphenylsulfonium tetrafluoroborate (2g)}

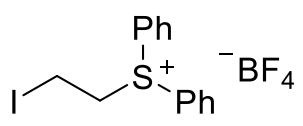

Grey solid (344.3 mg, 42\%), from diphenylsulfane (354.0 mg, $1.9 \mathrm{mmol}$ ), 1,2-diiodoethane $(563.8 \mathrm{mg}, 2.0 \mathrm{mmol})$, and silver tetrafluoroborate $(389.3 \mathrm{mg}, 2.0$ mmol). M.p.: $115.0-116.0{ }^{\circ} \mathrm{C} .{ }^{1} \mathrm{H}$ NMR $\left(500 \mathrm{MHz}, \mathrm{CDCl}_{3}\right) \delta 8.04(\mathrm{~d}, J=7.9 \mathrm{~Hz}, 4 \mathrm{H})$, $7.78(\mathrm{t}, J=7.4 \mathrm{~Hz}, 2 \mathrm{H}), 7.73(\mathrm{t}, J=7.7 \mathrm{~Hz}, 4 \mathrm{H}), 4.71(\mathrm{t}, J=6.5 \mathrm{~Hz}, 2 \mathrm{H}), 3.43(\mathrm{t}, J=$ 6.5 Hz, 2H). $\left.{ }^{19} \mathrm{~F} \mathrm{NMR} \mathrm{(471} \mathrm{MHz,} \mathrm{CDCl}_{3}\right) \delta-151.0 \mathrm{~Hz}$ to $-151.1 \mathrm{~Hz}(4 \mathrm{~F}) .{ }^{13} \mathrm{C}$ NMR $\left(126 \mathrm{MHz}, \mathrm{CDCl}_{3}\right) \delta 135.2,131.9,131.0$ (assigned to impurity), 130.9, 129.2 (assigned to impurity), 127.0 (assigned to impurity), 122.9, 48.5, -7.2 (2g decomposed during the ${ }^{13} \mathrm{C}$ NMR measurement). IR (KBr): 3064, 2978, 2928, 1579, 1480, 1449, 1445, 1419, 1276, 1250, 1155, 1028, 998, 908, 809, 750, 685, $636 \mathrm{~cm}^{-1}$. HRMS-ESI $(\mathrm{m} / \mathrm{z})$ calcd. for $\left[\mathrm{C}_{14} \mathrm{H}_{14} \mathrm{IS}\right]^{+}\left([\mathrm{M}]^{+}\right): 340.9856$; found: 340.9865 .

\subsection{Procedures for the synthesis of $2 \mathrm{~h}$.}




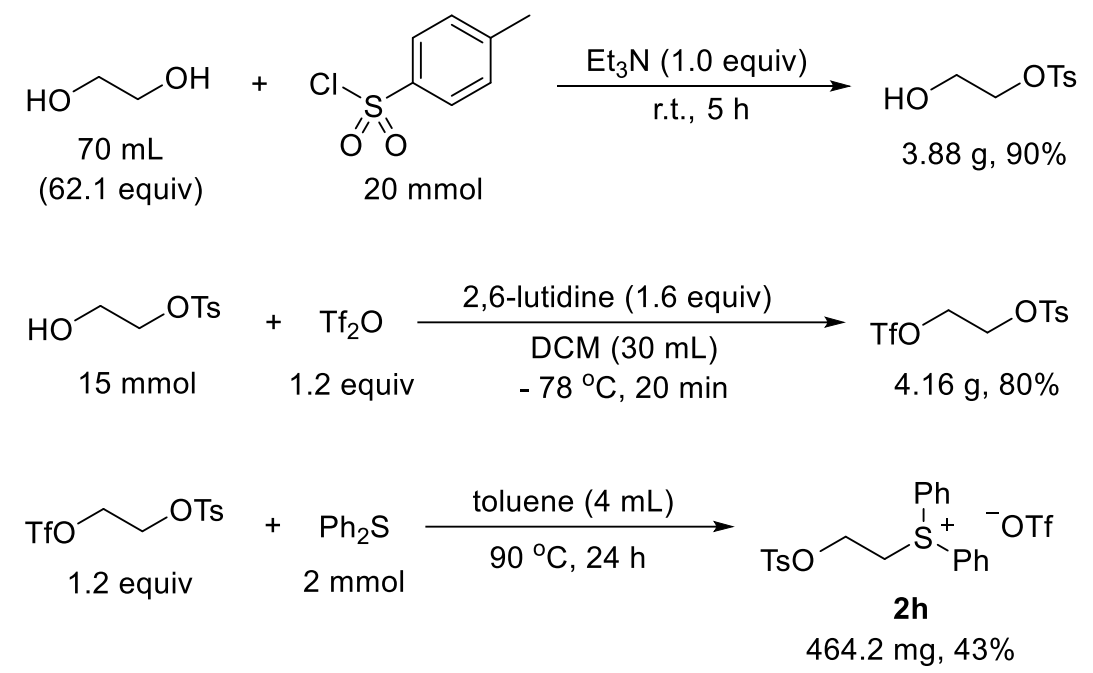

Step 1: ${ }^{5}$-Toluenesulfonyl chloride $(3.81 \mathrm{~g}, 20.0 \mathrm{mmol})$ was added to ethylene glycol $(70 \mathrm{~mL}, 1.242 \mathrm{~mol})$ with stirring. After $30 \mathrm{~min}$, triethylamine $(2.78 \mathrm{~mL}, 20 \mathrm{mmol})$ was added dropwise in 5 mins. The mixture was reacted at room temperature for $5 \mathrm{~h}$, diluted with $\mathrm{H}_{2} \mathrm{O}(70 \mathrm{~mL})$, and extracted with $\mathrm{CHCl}_{3}(100 \mathrm{~mL})$. The extract was dried over anhydrous $\mathrm{Na}_{2} \mathrm{SO}_{4}$ and concentrated to dryness under reduced pressure to afford 2-hydroxyethyl 4-methylbenzenesulfonate as a colorless viscous liquid (3.88 g, 90\%). Step 2: ${ }^{6}$ Under a nitrogen atmosphere, 2,6-lutidine $(2.80 \mathrm{~mL}, 24 \mathrm{mmol})$ was added to a solution of 2-hydroxyethyl 4-methylbenzenesulfonate (3.24 g, $15.0 \mathrm{mmol})$ in DCM $(30 \mathrm{~mL})$ at $-78{ }^{\circ} \mathrm{C}$ with vigorous stirring. $\mathrm{Tf}_{2} \mathrm{O}(3.50 \mathrm{~mL}, 18.0 \mathrm{mmol})$ was then added dropwise over 5 mins. The mixture was reacted at $-78{ }^{\circ} \mathrm{C}$ for 15 mins, quenched with $0.5 \mathrm{M} \mathrm{H}_{2} \mathrm{SO}_{4}$ aq $(50 \mathrm{~mL})$ at $-78{ }^{\circ} \mathrm{C}$, warmed to room temperature, and extracted with DCM $(3 \times 80 \mathrm{~mL})$. The combined organic layers were dried over anhydrous $\mathrm{Na}_{2} \mathrm{SO}_{4}$ and concentrated to dryness under reduce pressure. The residue was purified by column chromatography on silica gel using a mixture of petroleum ether / ethyl acetate $=5 / 1(\mathrm{v} / \mathrm{v})$ as eluents to afford 2-(((trifluoromethyl)sulfonyl)oxy)ethyl 4-methylbenzenesulfonate as a light brown viscous liquid (4.16 g, 80\%). ${ }^{1} \mathrm{H}$ NMR $\left(500 \mathrm{MHz}, \mathrm{CDCl}_{3}\right) \delta 7.77(\mathrm{~d}, J=7.8 \mathrm{~Hz}, 2 \mathrm{H}), 7.36(\mathrm{~d}, J=7.9 \mathrm{~Hz}, 2 \mathrm{H}), 4.64(\mathrm{t}, J=3.5$ $\mathrm{Hz}, 2 \mathrm{H}), 4.30(\mathrm{t}, J=3.9,2 \mathrm{H}), 2.43$ (s, 3H).

Step 3: ${ }^{3}$ A heavy-walled pressure tube $(15 \mathrm{~mL})$ with a teflon screwcap was charged with diphenylsulfane (372.6 mg, $2.0 \mathrm{mmol})$, 2-(((trifluoromethyl)sulfonyl)oxy)ethyl 4-methylbenzenesulfonate $(835.9 \mathrm{mg}, 2.4 \mathrm{mmol})$ and toluene $(4 \mathrm{~mL})$ with vigorous stirring. The tube was sealed and heated at $90{ }^{\circ} \mathrm{C}$ for $24 \mathrm{~h}$. The reaction mixture was cooled to room temperature and concentrated to ca. $2 \mathrm{~mL}$ under reduced pressure. 
Diethyl ether $(50 \mathrm{~mL})$ was added with stirring. After $30 \mathrm{mins}$, the resulting mixture was placed in a refrigerator $\left(-18{ }^{\circ} \mathrm{C}\right)$ overnight for crystallization. The precipitates were filtered, washed with diethyl ether $(2 \times 1.0 \mathrm{~mL})$, and dried in vacuum to afford diphenyl(2-(tosyloxy)ethyl)sulfonium triflate (2h) as a white solid (464.2 $\mathrm{mg}, 43 \%)$. M.p.: 74.5-75.1 ${ }^{\circ} \mathrm{C} .{ }^{1} \mathrm{H}$ NMR $\left(500 \mathrm{MHz}, \mathrm{CDCl}_{3}\right) \delta 8.05(\mathrm{~d}, J=8.0 \mathrm{~Hz}, 4 \mathrm{H}), 7.75(\mathrm{t}, J$ $=7.4 \mathrm{~Hz}, 2 \mathrm{H}), 7.70-7.67(\mathrm{~m}, 6 \mathrm{H}), 7.34(\mathrm{~d}, J=7.8 \mathrm{~Hz}, 2 \mathrm{H}), 4.73(\mathrm{t}, J=3.7 \mathrm{~Hz}, 2 \mathrm{H})$, $4.39(\mathrm{t}, J=4.0 \mathrm{~Hz}, 2 \mathrm{H}), 2.44(\mathrm{~s}, 3 \mathrm{H}) .{ }^{19} \mathrm{~F}$ NMR $\left(471 \mathrm{MHz}, \mathrm{CDCl}_{3}\right) \delta-78.3(\mathrm{~s}, 3 \mathrm{~F}) .{ }^{13} \mathrm{C}$ NMR $\left(126 \mathrm{MHz}, \mathrm{CDCl}_{3}\right) \delta 146.2,135.2,131.8,131.2,131.0,130.3,128.0,123.1$, 120.7 (q, $J=320.1 \mathrm{~Hz}), 63.2,45.4$, 21.7. IR (KBr): 3099, 3069, 3033, 2950, 1596, 1483, 1456, 1400, 1360, 1291, 1239, 1203, 1176, 1149, 1094, 1054, 1031, 997, 965, 897, 816, 757, 687, $639 \mathrm{~cm}^{-1}$. HRMS-ESI $(\mathrm{m} / \mathrm{z})$ calcd. for $\left[\mathrm{C}_{21} \mathrm{H}_{21} \mathrm{O}_{3} \mathrm{~S}_{2}\right]^{+}\left([\mathrm{M}]^{+}\right)$: 385.0927; found: 385.0929 .

\subsection{Procedure for the synthesis of $2 i$.}

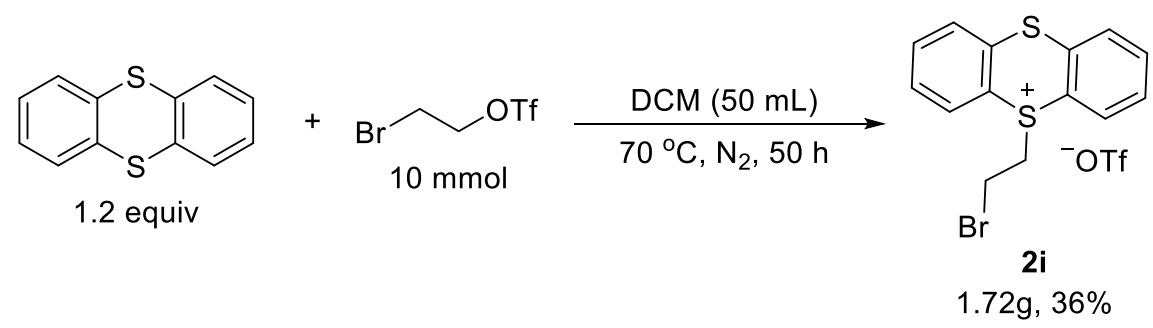

Under a nitrogen atmosphere, a heavy-walled pressure tube $(100 \mathrm{~mL})$ with a teflon screwcap was charged with 2-bromoethyl trifluoromethanesulfonate (2.57 g, 10.0 $\mathrm{mmol})$, thianthrene $(2.60 \mathrm{~g}, 12.0 \mathrm{mmol})$, and DCM $(50 \mathrm{~mL})$ with stirring. The tube was sealed and the mixture was reacted at $70^{\circ} \mathrm{C}$ for $50 \mathrm{~h}$, cooled to room temperature, and concentrated to dryness under reduced pressure. The crude product was purified by crystallization from DCM $(6 \mathrm{~mL}) /$ diethyl ether $(150 \mathrm{~mL})$ system to afford 5-(2-bromoethyl)-5H-thianthren-5-ium triflate (2i) as a light pale solid (1.72 g, 36\%). M.p.: 146.4-147.1 ${ }^{\circ} \mathrm{C} .{ }^{1} \mathrm{H}$ NMR $\left(500 \mathrm{MHz}, \mathrm{CDCl}_{3}\right) \delta 8.38(\mathrm{~d}, J=7.9 \mathrm{~Hz}, 2 \mathrm{H}), 7.87$ (d, $J=7.9 \mathrm{~Hz}, 2 \mathrm{H}), 7.78(\mathrm{t}, J=7.8 \mathrm{~Hz}, 2 \mathrm{H}), 7.70(\mathrm{t}, J=7.7 \mathrm{~Hz}, 2 \mathrm{H}), 4.32(\mathrm{t}, J=6.5 \mathrm{~Hz}$, $2 \mathrm{H}), 3.63(\mathrm{t}, J=6.5 \mathrm{~Hz}, 2 \mathrm{H}) .{ }^{19} \mathrm{~F} \mathrm{NMR}\left(471 \mathrm{MHz}, \mathrm{CDCl}_{3}\right) \delta-78.2(\mathrm{~s}, 3 \mathrm{~F}) .{ }^{13} \mathrm{C} \mathrm{NMR}$ $\left(126 \mathrm{MHz}, \mathrm{CDCl}_{3}\right) \delta 136.2,135.1,134.8,130.3,130.2,120.7$ (q, $\left.J=320.4 \mathrm{~Hz}\right), 116.9$, 43.0, 23.1. IR (KBr): 3075, 3039, 2988, 2930, 1570, 1452, 1398, 1271, 1258, 1160, 1027, 911, 846, 766, $634 \mathrm{~cm}^{-1}$. HRMS-ESI $(\mathrm{m} / \mathrm{z})$ calcd. for $\left[\mathrm{C}_{14} \mathrm{H}_{12} \mathrm{BrS}_{2}\right]^{+}\left([\mathrm{M}]^{+}\right)$: 322.9558; found: 322.9568 . 


\subsection{Procedure for the synthesis of $2 \mathbf{j}^{3}{ }^{3}$}

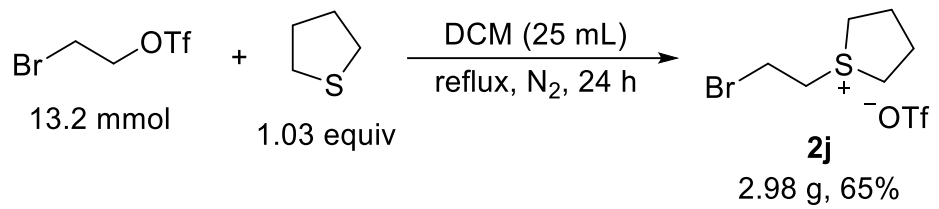

Under a nitrogen atmosphere, tetrahydrothiophene $(1.20 \mathrm{~g}, 13.6 \mathrm{mmol})$ was added dropwise to a stirred solution of 2-bromoethyl trifluoromethanesulfonate (3.40 g, 13.2 mmol) in DCM (25 mL) over 5 mins at room temperature. The mixture was then refluxed at $45{ }^{\circ} \mathrm{C}$ for $24 \mathrm{~h}$, cooled to room temperature, and concentrated to ca. $2 \mathrm{~mL}$ under reduced pressure. Diethyl ether $(20 \mathrm{~mL})$ was added with stirring. After $1 \mathrm{~h}$ at room temperature, the mixture was placed in a refrigerator $\left(-18{ }^{\circ} \mathrm{C}\right)$ overnight. The precipitates were collected, washed with cooled diether ether, and dried in vacuum to afford 1-(2-bromoethyl)tetrahydro-1 $H$-thiophen-1-ium triflate (2j) as a pale yellow solid $(2.98 \mathrm{~g}, 65 \%) .{ }^{1} \mathrm{H}$ NMR $\left(500 \mathrm{MHz}, \mathrm{CDCl}_{3}\right) \delta 3.95(\mathrm{t}, J=5.9 \mathrm{~Hz}, 2 \mathrm{H}), 3.87(\mathrm{t}, J$ $=5.9 \mathrm{~Hz}, 2 \mathrm{H}), 3.81-3.76(\mathrm{~m}, 2 \mathrm{H}), 3.71-3.67(\mathrm{~m}, 2 \mathrm{H}), 2.48-2.45(\mathrm{~m}, 2 \mathrm{H}), 2.40-2.37(\mathrm{~m}$, 2H). ${ }^{19} \mathrm{~F}$ NMR $\left(471 \mathrm{MHz}, \mathrm{CDCl}_{3}\right) \delta-78.4(\mathrm{~s}, 3 \mathrm{~F}) .{ }^{13} \mathrm{C}$ NMR $\left(126 \mathrm{MHz}, \mathrm{CDCl}_{3}\right) \delta$ $120.6(\mathrm{q}, J=319.8 \mathrm{~Hz}), 46.6,45.2,28.8,25.6$.

\section{Procedures for the synthesis of terminal alkynes.}

\subsection{Procedures for the synthesis of $1 d$.}
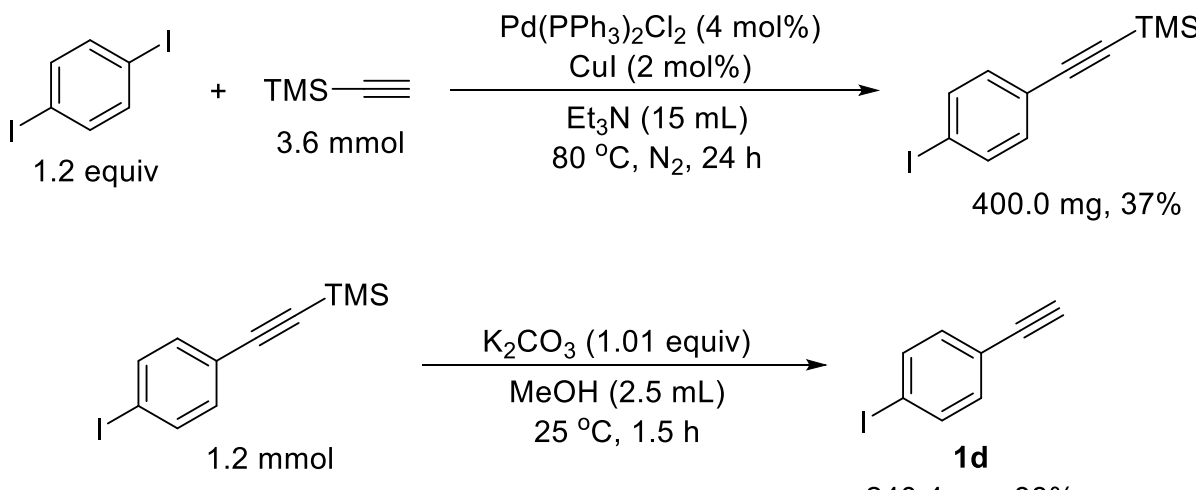

$240.4 \mathrm{mg}, 88 \%$

Step 1: ${ }^{7}$ Under a nitrogen atmosphere, a round-bottom flask $(25 \mathrm{~mL})$ was charged with $\mathrm{Pd}\left(\mathrm{PPh}_{3}\right)_{2} \mathrm{Cl}_{2}(101.1 \mathrm{mg}, 0.144 \mathrm{mmol}), \mathrm{CuI}(13.8 \mathrm{mg}, 0.072 \mathrm{mmol})$ and $\mathrm{Et}_{3} \mathrm{~N}(15$ $\mathrm{mL})$, followed by addition of 1,4-diiodobenzene (1.42 $\mathrm{g}, 4.32 \mathrm{mmol})$ and ethynyltrimethylsilane $(352.8 \mathrm{mg}, 3.6 \mathrm{mmol})$, with vigorous stirring. The mixture was reacted at $80{ }^{\circ} \mathrm{C}$ for $24 \mathrm{~h}$, cooled to room temperature, quenched with saturated 
aqueous $\mathrm{NH}_{4} \mathrm{Cl}$ solution $(20 \mathrm{~mL})$, and extracted with diethyl ether $(3 \times 15 \mathrm{~mL})$. The combined organic layers were washed with $\mathrm{H}_{2} \mathrm{O}(40 \mathrm{~mL})$ and saturated aqueous $\mathrm{NaCl}$ solution $(40 \mathrm{~mL})$, dried over anhydrous $\mathrm{Na}_{2} \mathrm{SO}_{4}$, and concentrated to dryness under reduced pressure. The residue was purified by column chromatography on silica gel using pentane as eluent to give ((4-iodophenyl)ethynyl)trimethylsilane (400.0 mg, $37 \%)$ as a white solid.

Step 2: ${ }^{8}$ A round-bottom flask $(25 \mathrm{~mL})$ was charged with ((4-iodophenyl)ethynyl) trimethylsilane (360.3 mg, $1.2 \mathrm{mmol}), \mathrm{K}_{2} \mathrm{CO}_{3}(167.5 \mathrm{mg}, 1.21 \mathrm{mmol})$, and $\mathrm{MeOH}$ (2.5 mL) with stirring. The mixture was reacted at $25{ }^{\circ} \mathrm{C}$ for $1.5 \mathrm{~h}$, diluted with $\mathrm{H}_{2} \mathrm{O}$ $(20 \mathrm{~mL})$, and extracted with pentane $(2 \times 30 \mathrm{~mL})$. The organic layers were dried over anhydrous $\mathrm{Na}_{2} \mathrm{SO}_{4}$ and concentrated to dryness under reduced pressure. The residue was purified by column chromatography on silica gel using pentane as eluent to give 1-ethynyl-4-iodobenzene (1d) as a white solid (240.4 mg, 88\%). ${ }^{1} \mathrm{H}$ NMR (500 MHz, $\left.\mathrm{CDCl}_{3}\right) \delta 7.67(\mathrm{dm}, J=8.5 \mathrm{~Hz}, 2 \mathrm{H}), 7.21(\mathrm{dm}, J=8.5 \mathrm{~Hz}, 2 \mathrm{H}), 3.13(\mathrm{~s}, 1 \mathrm{H})$.

\subsection{Typical procedures for the synthesis of $1 \mathrm{~h}-\mathrm{i}$ and $1 \mathrm{~s} .^{8}$}
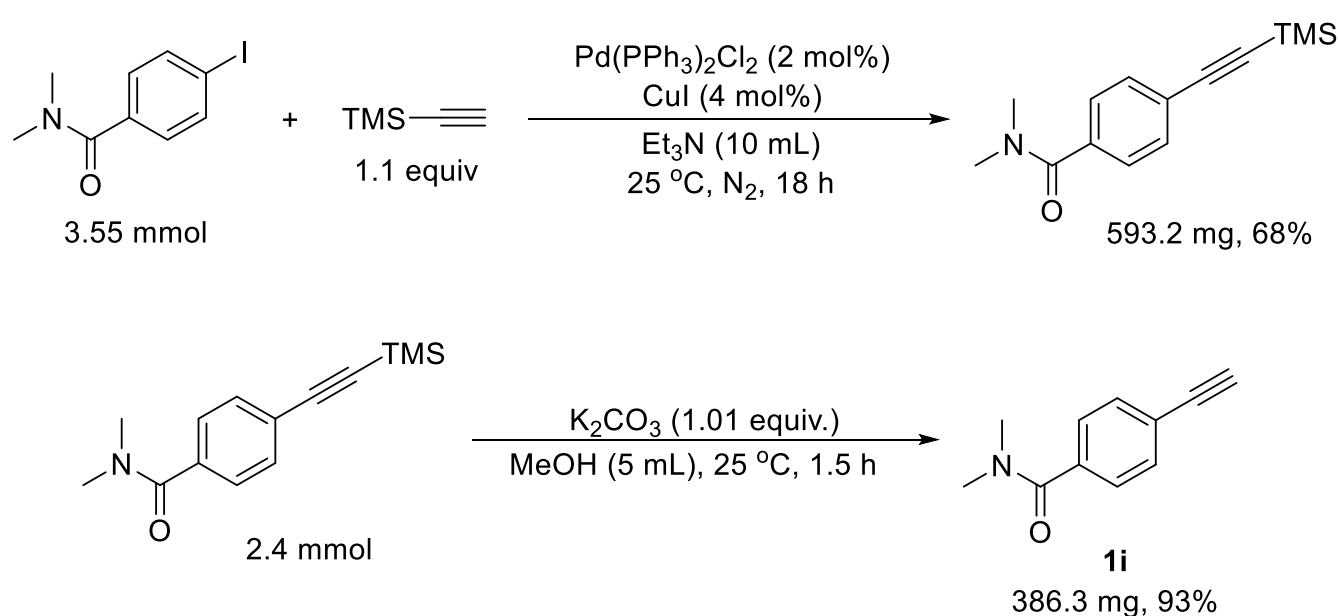

Taking 4-ethynyl- $N, N$-dimethylbenzamide (1i) as an example.

Step 1: Under a nitrogen atmosphere, a round-bottom flask $(50 \mathrm{~mL})$ was charged with 4-iodo- $N, N$-dimethylbenzamide $(976.6 \mathrm{mg}, 3.55 \mathrm{mmol})$ and $\mathrm{Et}_{3} \mathrm{~N}(10 \mathrm{~mL})$, followed by addition of $\mathrm{Pd}\left(\mathrm{PPh}_{3}\right)_{2} \mathrm{Cl}_{2}(50.6 \mathrm{mg}, 0.072 \mathrm{mmol}), \mathrm{CuI}(26.5 \mathrm{mg}, 0.139 \mathrm{mmol})$ and ethynyltrimethylsilane $(382.9 \mathrm{mg}, 3.9 \mathrm{mmol})$, with stirring. The mixture was reacted at $25{ }^{\circ} \mathrm{C}$ for $18 \mathrm{~h}$ and concentrated to dryness under reduced pressure. The residue was purified by column chromatography on silica gel using petroleum ether / ethyl acetate 
$=2 / 1(\mathrm{v} / \mathrm{v})$ as eluents to give $N, N$-dimethyl-4-((trimethylsilyl)ethynyl) benzamide as a white solid (593.2 $\mathrm{mg}, 68 \%)$.

Step 2: A round-bottom flask $(25 \mathrm{~mL})$ was charged with $N, N$-dimethyl-4((trimethylsilyl)ethynyl)benzamide (589.0 mg, $2.4 \mathrm{mmol}), \mathrm{K}_{2} \mathrm{CO}_{3}(334.4 \mathrm{mg}, 2.42$ $\mathrm{mmol})$, and $\mathrm{MeOH}(5 \mathrm{~mL})$ with stirring. The mixture was reacted at $25{ }^{\circ} \mathrm{C}$ for $1.5 \mathrm{~h}$, diluted with $\mathrm{H}_{2} \mathrm{O}(20 \mathrm{~mL})$, and extracted with DCM $(30 \mathrm{~mL})$. The organic solution was dried over anhydrous $\mathrm{Na}_{2} \mathrm{SO}_{4}$ and concentrated to dryness under reduced pressure. The residue was purified by column chromatography on silica gel using petroleum ether / ethyl acetate $=2 / 1(\mathrm{v} / \mathrm{v})$ as eluents to give 4-ethynyl- $N, N$-dimethyl benzamide (1i) as a white solid (386.3 mg, 93\%). ${ }^{1} \mathrm{H}$ NMR $\left(500 \mathrm{MHz}, \mathrm{CDCl}_{3}\right) \delta 7.50$ $(\mathrm{dm}, J=8.3 \mathrm{~Hz}, 2 \mathrm{H}), 7.36(\mathrm{dm}, J=8.4 \mathrm{~Hz}, 2 \mathrm{H}), 3.13(\mathrm{~s}, 1 \mathrm{H}), 3.09(\mathrm{~s}, 3 \mathrm{H}), 2.94(\mathrm{~s}$, $3 \mathrm{H})$.

\subsection{Procedures for the synthesis of 11 .}
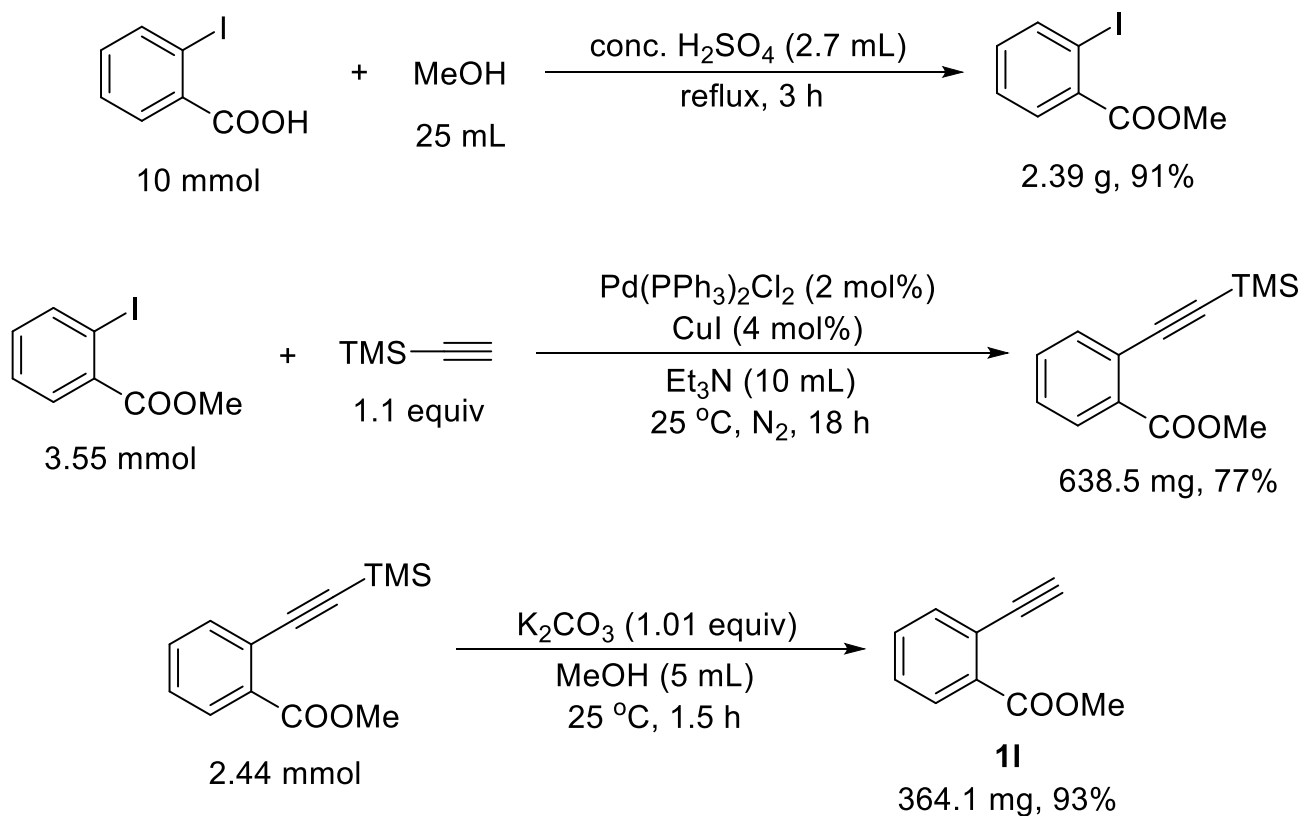

Step 1: ${ }^{9}$ A round-bottom flask (100 mL) was charged with 2-iodobenzoic acid (2.5 g, $10.0 \mathrm{mmol}$ ) and $2.0 \mathrm{~mol} / \mathrm{L} \mathrm{H}_{2} \mathrm{SO}_{4}$ in $\mathrm{MeOH}(25 \mathrm{~mL})$ with vigorous stirring. The mixture was reacted at reflux for $3 \mathrm{~h}$, cooled to room temperature, diluted with $20 \mathrm{~mL}$ of water, and extracted with ethyl acetate $(3 \times 15 \mathrm{~mL})$. The combined organic layers were washed with saturated aqueous $\mathrm{NaCl}$ solution $(50 \mathrm{~mL})$, dried over anhydrous $\mathrm{Na}_{2} \mathrm{SO}_{4}$, and concentrated to dryness under reduced pressure to give methyl 2-iodobenzoate $(2.39 \mathrm{~g}, 91 \%)$ as a light yellow oil. 
Step 2: ${ }^{8}$ Under a nitrogen atmosphere, a round-bottom flask $(50 \mathrm{~mL})$ was charged with methyl 2-iodobenzoate $(931.0 \mathrm{mg}, 3.55 \mathrm{mmol})$ and $\mathrm{Et}_{3} \mathrm{~N}(10 \mathrm{~mL})$, followed by addition of $\mathrm{Pd}\left(\mathrm{PPh}_{3}\right)_{2} \mathrm{Cl}_{2}(50.6 \mathrm{mg}, 0.072 \mathrm{mmol}), \mathrm{CuI}(26.5 \mathrm{mg}, 0.139 \mathrm{mmol})$, and ethynyltrimethylsilane $(382.9 \mathrm{mg}, 3.9 \mathrm{mmol})$, with vigorous stirring. The mixture was reacted at $25{ }^{\circ} \mathrm{C}$ for $18 \mathrm{~h}$ and concentrated to dryness under reduced pressure. The residue was purified by column chromatography on silica gel using petroleum ether / ethyl acetate $=40 / 1(\mathrm{v} / \mathrm{v})$ as eluents to give methyl 2-((trimethylsilyl)ethynyl $)$ benzoate as a colorless oil $(638.5 \mathrm{mg}, 77 \%)$.

Step $3^{8}$ : A round-bottom flask $(25 \mathrm{~mL})$ was charged with methyl 2-((trimethylsilyl)ethynyl)benzoate (567.0 mg, $2.44 \mathrm{mmol}), \mathrm{K}_{2} \mathrm{CO}_{3}(341.0 \mathrm{mg}, 2.46$ $\mathrm{mmol})$, and $\mathrm{MeOH}(5 \mathrm{~mL})$ with stirring. The mixture was reacted at $25{ }^{\circ} \mathrm{C}$ for $1.5 \mathrm{~h}$, diluted with $\mathrm{H}_{2} \mathrm{O}(20 \mathrm{~mL})$, and extracted with DCM (30 mL). The organic solution was dried over anhydrous $\mathrm{Na}_{2} \mathrm{SO}_{4}$ and concentrated to dryness under reduced pressure. The residue was purified by column chromatography on silica gel using petroleum ether / ethyl acetate $=40 / 1(\mathrm{v} / \mathrm{v})$ as eluents to give methyl 2-ethynylbenzoate $(\mathbf{1 1})$ as a brown oil (364.1 mg, 93\%). ${ }^{1} \mathrm{H}$ NMR $\left(500 \mathrm{MHz}, \mathrm{CDCl}_{3}\right) \delta 7.93(\mathrm{~d}, J=7.8 \mathrm{~Hz}, 1 \mathrm{H})$, $7.62(\mathrm{~d}, J=7.7 \mathrm{~Hz}, 1 \mathrm{H}), 7.47(\mathrm{t}, J=7.6 \mathrm{~Hz}, 1 \mathrm{H}), 7.39$ (t, $J=7.6 \mathrm{~Hz}, 1 \mathrm{H}), 3.92(\mathrm{~s}, 3 \mathrm{H})$, $3.39(\mathrm{~s}, 1 \mathrm{H})$.

\subsection{Procedure for the synthesis of $1 u^{10}$}

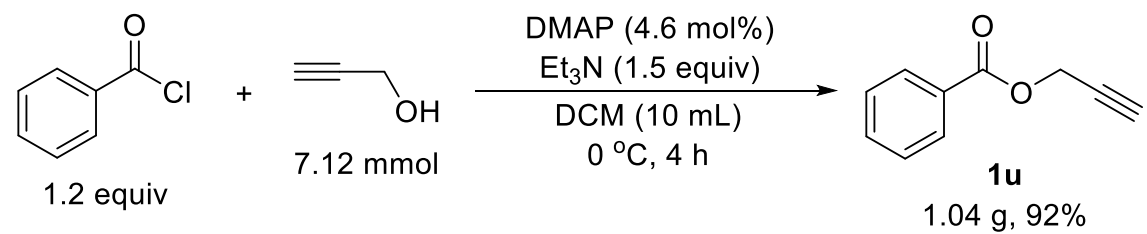

To a solution of prop-2-yn-1-ol $(399.1 \mathrm{mg}, 7.12 \mathrm{mmol})$ in DCM $(10 \mathrm{~mL})$ was added $\mathrm{Et}_{3} \mathrm{~N}(1.48 \mathrm{~mL}, 10.7 \mathrm{mmol})$ and DMAP $(40 \mathrm{mg}, 0.33 \mathrm{mmol})$ at $0{ }^{\circ} \mathrm{C}$ with vigorous stirring. After $10 \mathrm{mins}$, benzoyl chloride $(601.8 \mathrm{mg}, 8.56 \mathrm{mmol})$ was added. The mixture was reacted at $0{ }^{\circ} \mathrm{C}$ for another $4 \mathrm{~h}$, quenched by $\mathrm{H}_{2} \mathrm{O}(10 \mathrm{~mL})$, and extracted with DCM $(2 \times 20 \mathrm{~mL})$. The combined organic layers were dried over anhydrous $\mathrm{Na}_{2} \mathrm{SO}_{4}$ and concentrated to dryness under reduced pressure. The residue was purified by column chromatography on silica gel using petroleum ether / ethyl acetate $=80 / 1$ (v / v) as eluents to give prop-2-yn-1-yl benzoate as a colorless oil $(1.04 \mathrm{~g}, 92 \%) .{ }^{1} \mathrm{H}$ 
NMR (500 MHz, $\left.\mathrm{CDCl}_{3}\right) \delta 8.07(\mathrm{~d}, J=7.8 \mathrm{~Hz}, 2 \mathrm{H}), 7.57(\mathrm{t}, J=7.5 \mathrm{~Hz}, 1 \mathrm{H}), 7.44(\mathrm{t}, J$ $=7.7 \mathrm{~Hz}, 2 \mathrm{H}), 4.92(\mathrm{~d}, J=2.5 \mathrm{~Hz}, 2 \mathrm{H}), 2.53(\mathrm{t}, J=2.4 \mathrm{~Hz}, 1 \mathrm{H})$.

\subsection{Procedure for the synthesis of $1 \mathrm{v} .{ }^{11}$}

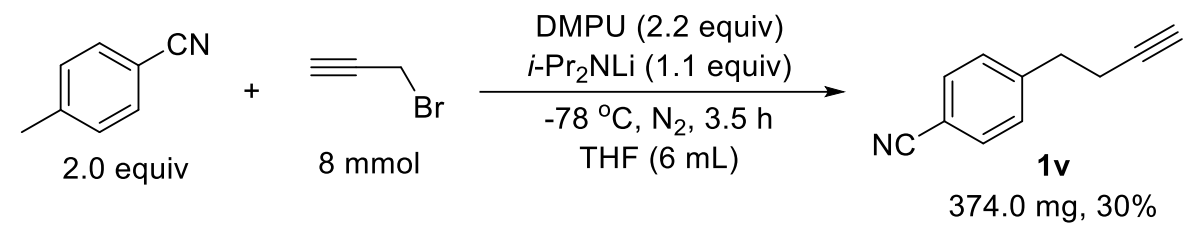

Under a nitrogen atmosphere, DMPU $(2.2 \mathrm{~mL}, 17.6 \mathrm{mmol})$ was added to a solution of lithium diisopropylamide ( $8.8 \mathrm{mmol}, 2 \mathrm{~mol} / \mathrm{L}$ in THF) at $-78{ }^{\circ} \mathrm{C}$ with vigorous stirring. After $1 \mathrm{~h}$, a solution of 4-methylbenzonitrile $(1.92 \mathrm{~mL}, 16.0 \mathrm{mmol})$ in THF $(6 \mathrm{~mL})$ was added dropwise. After another $1 \mathrm{~h}, 3$-bromoprop-1-yne $(0.92 \mathrm{~mL}, 8.0 \mathrm{mmol})$ was added dropwise. The resulting mixture was reacted at $-78{ }^{\circ} \mathrm{C}$ for another $1.5 \mathrm{~h}$, warmed to $-40{ }^{\circ} \mathrm{C}$, quenched with saturated $\mathrm{NH}_{4} \mathrm{Cl}$ solution $(30 \mathrm{~mL})$, and extracted with ethyl acetate $(30 \mathrm{~mL})$. The organic layer was washed with $\mathrm{H}_{2} \mathrm{O}(30 \mathrm{~mL})$, dried over anhydrous $\mathrm{Na}_{2} \mathrm{SO}_{4}$, and concentrated to dryness under reduced pressure. The residue was purified by column chromatography on silica gel using petroleum ether / ethyl acetate $=80 / 1$ (v/v) as eluents to give 4-(but-3-yn-1-yl)benzonitrile as a white solid (374.0 mg, 30\%). ${ }^{1} \mathrm{H} \mathrm{NMR}\left(500 \mathrm{MHz}, \mathrm{CDCl}_{3}\right) \delta 7.59$ (d, $\left.J=8.2 \mathrm{~Hz}, 2 \mathrm{H}\right), 7.34$ (t, $J=8.1 \mathrm{~Hz}, 2 \mathrm{H}), 2.89(\mathrm{t}, J=7.2 \mathrm{~Hz}, 2 \mathrm{H}), 2.51(\mathrm{td}, J=7.3 \mathrm{~Hz}, 2.6 \mathrm{~Hz}, 2 \mathrm{H}), 1.98(\mathrm{t}, J=$ $2.6 \mathrm{~Hz}, 1 \mathrm{H})$.

\subsection{Procedure for the synthesis of $1 w^{12}$}

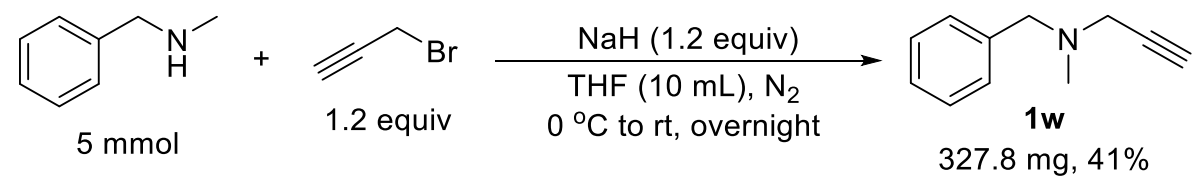

Under a nitrogen atmosphere, $\mathrm{NaH}(240.0 \mathrm{mg}, 60 \%, 6 \mathrm{mmol})$ was added to a solution of $N$-methyl-1-phenylmethanamine $(606.0 \mathrm{mg}, 5 \mathrm{mmol})$ in $\mathrm{THF}(10 \mathrm{~mL})$ at $-20{ }^{\circ} \mathrm{C}$ with vigorous stirring. The mixture was reacted at $25^{\circ} \mathrm{C}$ until complete release of $\mathrm{H}_{2}$ gas. Then, 3-bromoprop-1-yne $(0.55 \mathrm{~mL}, 6 \mathrm{mmol})$ was added at $0{ }^{\circ} \mathrm{C}$. The resulting mixture was kept at room temperature overnight, washed with $\mathrm{H}_{2} \mathrm{O}(20 \mathrm{~mL})$, and extracted with dichloromethane $(30 \mathrm{~mL})$. The organic layer was washed with brine, dried over anhydrous $\mathrm{Na}_{2} \mathrm{SO}_{4}$, and concentrated to dryness under reduced pressure. The residue was purified by column chromatography on silica gel using petroleum 
ether $/$ ethyl acetate $=30 / 1(\mathrm{v} / \mathrm{v})$ as eluents to give $N$-benzyl- $N$-methylprop-2yn-1-amine as a light yellow oil. ${ }^{1} \mathrm{H}$ NMR $\left(500 \mathrm{MHz}, \mathrm{CDCl}_{3}\right) \delta$ 7.34-7.30 (m, 4H), $7.25(\mathrm{t}, J=6.6 \mathrm{~Hz}, 1 \mathrm{H}), 3.57(\mathrm{~s}, 2 \mathrm{H}), 3.30(\mathrm{~d}, J=2.3 \mathrm{~Hz}, 2 \mathrm{H}), 2.34(\mathrm{~s}, 3 \mathrm{H}), 2.26(\mathrm{t}, J$ $=2.2 \mathrm{~Hz}, 1 \mathrm{H})$.

\section{General procedures for vinylation of terminal alkyne (1) with (2-bromoethyl) diphenylsulfonium triflate (2a).}

Procedure A (one-pot reactions, for products with low boiling points only): In a nitrogen filled glovebox, a sealed tube was charged with $\mathrm{Pd}\left(\mathrm{PPh}_{3}\right)_{4}(0.01 \mathrm{mmol}), \mathrm{CuI}$ (0.01 mmol), (2-bromoethyl)diphenylsulfonium triflate $(133.0 \mathrm{mg}, 0.3 \mathrm{mmol})$, terminal alkyne (1, $0.2 \mathrm{mmol}), \mathrm{K}_{3} \mathrm{PO}_{4}(63.7 \mathrm{mg}, 0.3 \mathrm{mmol})$, and DME (2 mL) with vigorous stirring. The mixture was reacted at $25{ }^{\circ} \mathrm{C}$ for $12 \mathrm{~h}$, diluted with diethyl ether (10 mL), and washed with $\mathrm{H}_{2} \mathrm{O}(15 \mathrm{~mL})$. The aqueous solution was extracted with diethyl ether $(10 \mathrm{~mL})$. The combined organic layers were dried over anhydrous $\mathrm{Na}_{2} \mathrm{SO}_{4}$ and concentrated to dryness under reduced pressure at ca. $10{ }^{\circ} \mathrm{C}$. The residue was purified by column chromatography on silica gel using pentane as eluent to give the desired product (3).

Procedure B (one-pot reactions): In a nitrogen filled glovebox, a sealed tube was $\begin{array}{llllll}\text { charged with } & \mathrm{Pd}\left(\mathrm{PPh}_{3}\right)_{4} & (0.01 \quad \mathrm{mmol}), & \mathrm{CuI} & (0.01 & \mathrm{mmol}) \text {, }\end{array}$ (2-bromoethyl)diphenylsulfonium triflate $(133.0 \mathrm{mg}, 0.3 \mathrm{mmol})$, terminal alkyne (1, $0.2 \mathrm{mmol}), \mathrm{K}_{3} \mathrm{PO}_{4}(63.7 \mathrm{mg}, 0.3 \mathrm{mmol})$, and DME (2 mL) with vigorous stirring. The mixture was reacted at $25{ }^{\circ} \mathrm{C}$ for $12 \mathrm{~h}$ and concentrated to dryness under reduced pressure. The residue was purified by column chromatography on silica gel using petroleum ether or a mixture of petroleum ether (or hexane) and ethyl acetate as eluents to give the desired product (3).

Procedure $\mathrm{C}$ (stepwise reactions, for products with low boiling points only): In a nitrogen filled glovebox, a sealed tube was charged with (2-bromoethyl)diphenylsulfonium triflate (133.0 mg, $0.3 \mathrm{mmol}), \mathrm{K}_{3} \mathrm{PO}_{4}(63.7 \mathrm{mg}, 0.3$ mmol), and DME ( $1 \mathrm{~mL}$ ) with vigorous stirring. The mixture was reacted at $25{ }^{\circ} \mathrm{C}$ for 20 mins. Then, $\mathrm{Pd}\left(\mathrm{PPh}_{3}\right)_{4}(0.01 \mathrm{mmol}), \mathrm{CuI}(0.01 \mathrm{mmol})$, terminal alkyne $(\mathbf{1}, 0.2$ mmol), and DME ( $1 \mathrm{~mL})$ were added. The resulting mixture was reacted at $25{ }^{\circ} \mathrm{C}$ for another $12 \mathrm{~h}$, diluted with ethyl ether $(10 \mathrm{~mL})$, and washed with $\mathrm{H}_{2} \mathrm{O}(15 \mathrm{~mL})$. The aqueous solution was extracted with ethyl ether $(10 \mathrm{~mL})$. The combined organic 
layers were dried over anhydrous $\mathrm{Na}_{2} \mathrm{SO}_{4}$ and concentrated to dryness under reduced pressure at ca. $10{ }^{\circ} \mathrm{C}$. The residue was purified by column chromatography on silica gel using pentane as eluent to give the desired product (3).

Procedure D (stepwise reactions): In a nitrogen filled glovebox, a sealed tube was charged with (2-bromoethyl)diphenylsulfonium triflate (133.0 mg, $0.3 \mathrm{mmol}$ ), $\mathrm{K}_{3} \mathrm{PO}_{4}$ (63.7 $\mathrm{mg}, 0.3 \mathrm{mmol})$, and DME $(1 \mathrm{~mL})$ with vigorous stirring. The mixture was reacted at $25^{\circ} \mathrm{C}$ for 20 mins. Then, $\mathrm{Pd}\left(\mathrm{PPh}_{3}\right)_{4}(0.01 \mathrm{mmol}), \mathrm{CuI}(0.01 \mathrm{mmol})$, terminal alkyne (1, $0.2 \mathrm{mmol})$, and DME (1 $\mathrm{mL})$ were added. The resulting mixture was reacted at $25{ }^{\circ} \mathrm{C}$ for another $12 \mathrm{~h}$ and concentrated to dryness under reduced pressure. The residue was purified by column chromatography on silica gel using petroleum ether or a mixture of petroleum ether (or hexane) and ethyl acetate as eluents to give the desired product (3).

But-3-en-1-yn-1-ylbenzene $(\mathbf{3 a})^{13}$

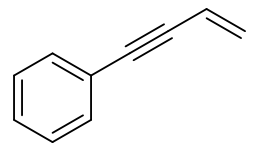

Colorless oil (12.3 mg from Procedure A, 48\%), pentane as eluent for column chromatography. ${ }^{1} \mathrm{H}$ NMR (500 MHz, $\left.\mathrm{CDCl}_{3}\right) \delta 7.45(\mathrm{~m}, 2 \mathrm{H}), 7.33-7.31(\mathrm{~m}, 3 \mathrm{H}), 6.03$ (dd, $J=17.5 \mathrm{~Hz}, 11.2 \mathrm{~Hz}, 1 \mathrm{H}), 5.74$ (dd, $J=17.5 \mathrm{~Hz}, 2.1 \mathrm{~Hz}, 1 \mathrm{H}), 5.55$ (dd, $J=11.1$ $\mathrm{Hz}, 2.0 \mathrm{~Hz}, 1 \mathrm{H}) .{ }^{13} \mathrm{C} \mathrm{NMR}\left(126 \mathrm{MHz}, \mathrm{CDCl}_{3}\right) \delta 131.6,128.3,128.3,126.9,123.2$, 117.2, 90.0, 88.1.

1-(But-3-en-1-yn-1-yl)-4-chlorobenzene $(\mathbf{3 b})^{13}$

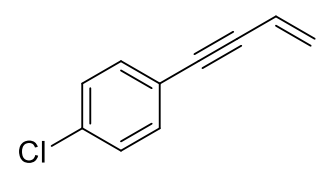

Colorless oil (17.7 mg from Procedure A, 54\%; $29.8 \mathrm{mg}$ from Procedure C, 92\%), pentane as eluent for column chromatography. ${ }^{1} \mathrm{H} \mathrm{NMR}\left(500 \mathrm{MHz}, \mathrm{CDCl}_{3}\right) \delta 7.37$ $(\mathrm{dm}, J=8.6 \mathrm{~Hz}, 2 \mathrm{H}), 7.30(\mathrm{dm}, J=8.6 \mathrm{~Hz}, 2 \mathrm{H}), 6.01(\mathrm{dd}, J=17.6 \mathrm{~Hz}, 11.2 \mathrm{~Hz}, 1 \mathrm{H})$, $5.75(\mathrm{dd}, J=17.6 \mathrm{~Hz}, 2.0 \mathrm{~Hz}, 1 \mathrm{H}), 5.57(\mathrm{dd}, J=11.2 \mathrm{~Hz}, 2.0 \mathrm{~Hz}, 1 \mathrm{H}) .{ }^{13} \mathrm{C}$ NMR $(126$ $\left.\mathrm{MHz}, \mathrm{CDCl}_{3}\right) \delta 134.3,132.8,128.7,127.3,121.7,117.0,89.0,88.8 . \mathrm{IR}(\mathrm{KBr}): 3100$, 3011, 1609, 1587, 1489, 1467, 1395, 1266, 1093, 1014, 969, 921, 826, $742 \mathrm{~cm}^{-1}$. HRMS-ESI $(\mathrm{m} / \mathrm{z})$ calcd. for $\mathrm{C}_{10} \mathrm{H}_{8} \mathrm{Cl}\left([\mathrm{M}+\mathrm{H}]^{+}\right)$: 163.0309; found: 163.0312 . 
1-Bromo-4-(but-3-en-1-yn-1-yl)benzene (3c) ${ }^{13}$

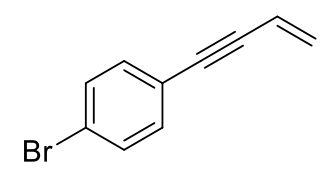

Colorless oil (22.3 mg from Procedure A, 54\%; $29.6 \mathrm{mg}$ from Procedure C, 71\%), pentane as eluent for column chromatography. ${ }^{1} \mathrm{H} \mathrm{NMR}\left(500 \mathrm{MHz}, \mathrm{CDCl}_{3}\right) \delta 7.46(\mathrm{~d}$, $J=7.3 \mathrm{~Hz}, 2 \mathrm{H}), 7.31(\mathrm{~d}, J=7.3 \mathrm{~Hz}, 2 \mathrm{H}), 6.00(\mathrm{dd}, J=17.5 \mathrm{~Hz}, 11.2 \mathrm{~Hz}, 1 \mathrm{H}), 5.75$ $(\mathrm{dm}, J=17.6 \mathrm{~Hz}, 1 \mathrm{H}), 5.58(\mathrm{dm}, J=11.2 \mathrm{~Hz}, 1 \mathrm{H}) .{ }^{13} \mathrm{C} \mathrm{NMR}\left(126 \mathrm{MHz}, \mathrm{CDCl}_{3}\right) \delta$ 133.0, 131.6, 127.4, 122.5, 122.1, 117.0, 89.2, 88.9. IR (KBr): 3100, 3010, 1607, 1582, 1484, 1464, 1394, 1265, 1095, 1069, 1011, 969, 921, 823, $727 \mathrm{~cm}^{-1}$. HRMS-ESI (m/z) calcd. for $\mathrm{C}_{10} \mathrm{H}_{8} \mathrm{Br}\left([\mathrm{M}+\mathrm{H}]^{+}\right)$: 206.9804; found: 206.9810 .

1-(But-3-en-1-yn-1-yl)-4-iodobenzene (3d)

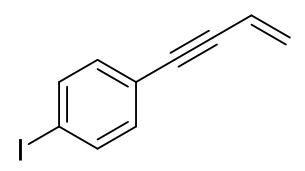

White solid (30.0 mg from Procedure A (THF as a solvent for $24 \mathrm{~h}$ ), 59\%), pentane as eluent for column chromatography. M.p.: 32.8-33.6 ${ }^{\circ} \mathrm{C} .{ }^{1} \mathrm{H}$ NMR $(500 \mathrm{MHz}$, $\left.\mathrm{CDCl}_{3}\right) \delta 7.66(\mathrm{~d}, J=8.1 \mathrm{~Hz}, 2 \mathrm{H}), 7.17(\mathrm{~d}, J=8.1 \mathrm{~Hz}, 2 \mathrm{H}), 6.00(\mathrm{dd}, J=17.6 \mathrm{~Hz}$, $11.2 \mathrm{~Hz}, 1 \mathrm{H}), 5.75(\mathrm{dm}, J=17.5 \mathrm{~Hz}, 1 \mathrm{H}), 5.57(\mathrm{dm}, J=11.2 \mathrm{~Hz}, 1 \mathrm{H}) .{ }^{13} \mathrm{C}$ NMR $(126$ $\left.\mathrm{MHz}, \mathrm{CDCl}_{3}\right) \delta 137.5,133.1,127.4,122.7,117.0,94.2,89.5$, 89.0. IR (KBr): 3001, 1648, 1607, 1594, 1574, 1480, 1464, 1412, 1388, 1262, 1057, 1005, 970, 921, 818, 718, $680 \mathrm{~cm}^{-1}$. HRMS-ESI $(\mathrm{m} / \mathrm{z})$ calcd. for $\mathrm{C}_{10} \mathrm{H}_{8} \mathrm{I}\left([\mathrm{M}+\mathrm{H}]^{+}\right): 254.9665$; found: 254.9670 .

1-(But-3-en-1-yn-1-yl)-4-(trifluoromethyl)benzene (3e) ${ }^{14}$<smiles>C=CC#Cc1ccc(C(F)(F)F)cc1</smiles>

Colorless oil (24.5 mg from Procedure A (24 h), 63\%), pentane as eluent for column chromatography. ${ }^{1} \mathrm{H}$ NMR $\left(500 \mathrm{MHz}, \mathrm{CDCl}_{3}\right) \delta$ 7.59-7.53 (m, 4H), $6.03(\mathrm{dd}, J=17.6$ $\mathrm{Hz}, 11.2 \mathrm{~Hz}, 1 \mathrm{H}), 5.80(\mathrm{dm}, J=17.6 \mathrm{~Hz}, 1 \mathrm{H}), 5.62(\mathrm{dm}, J=11.2 \mathrm{~Hz}, 1 \mathrm{H}) .{ }^{19} \mathrm{~F}$ NMR $\left(471 \mathrm{MHz}, \mathrm{CDCl}_{3}\right) \delta-62.9(\mathrm{~s}, 3 \mathrm{~F}) .{ }^{13} \mathrm{C} \mathrm{NMR}\left(126 \mathrm{MHz}, \mathrm{CDCl}_{3}\right) \delta 131.8,130.0(\mathrm{q}, J$ 
$=32.8 \mathrm{~Hz}), 128.1,127.0(\mathrm{q}, J=1.2 \mathrm{~Hz}), 125.3(\mathrm{q}, J=3.8 \mathrm{~Hz}), 123.9(\mathrm{q}, J=271.9 \mathrm{~Hz})$, 116.7, 90.4, 88.5. IR (KBr): 3058, 1731, 1617, 1509, 1453, 1406, 1323, 1242, 1169 , 1129, 1105, 1065, 1018, 970, 921, 841, $754 \mathrm{~cm}^{-1}$. HRMS-EI (m/z) calcd. for $\mathrm{C}_{11} \mathrm{H}_{7} \mathrm{~F}_{3}$ $\left([\mathrm{M}]^{+}\right)$: 196.0494; found: 196.0499 .

1-(But-3-en-1-yn-1-yl)-4-nitrobenzene (3f) ${ }^{13}$

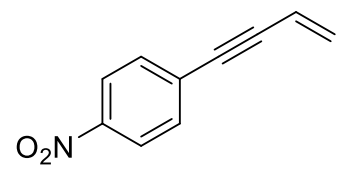

Light yellow solid (30.4 mg from Procedure B, 98\%; $27.5 \mathrm{mg}$ from Procedure D, $79 \%$ ), a mixture of petroleum ether / ethyl acetate $=80 / 1(\mathrm{v} / \mathrm{v})$ as eluents for column chromatography. M.p.: 57.2-59.1 ${ }^{\circ} \mathrm{C} .{ }^{1} \mathrm{H}$ NMR $\left(500 \mathrm{MHz}, \mathrm{CDCl}_{3}\right) \delta 8.19$ (d, $J$ $=8.6 \mathrm{~Hz}, 2 \mathrm{H}), 7.57(\mathrm{~d}, J=8.6 \mathrm{~Hz}, 2 \mathrm{H}), 6.04(\mathrm{dd}, J=17.5 \mathrm{~Hz}, 11.2 \mathrm{~Hz}, 1 \mathrm{H}), 5.83(\mathrm{dm}$, $J=17.5 \mathrm{~Hz}, 1 \mathrm{H}), 5.67(\mathrm{dm}, J=11.2 \mathrm{~Hz}, 1 \mathrm{H}) .{ }^{13} \mathrm{C} \mathrm{NMR}\left(126 \mathrm{MHz}, \mathrm{CDCl}_{3}\right) \delta 147.1$, 132.3, 130.1, 129.1, 123.6, 116.5, 93.2, 88.0. IR (KBr): 3104, 2217, 2183, 1682, 1651, 1597, 1511, 1490, 1342, 1285, 1270, 1106, 972, 940, 853, 748, $686 \mathrm{~cm}^{-1}$. HRMS-ESI (m/z) calcd. for $\mathrm{C}_{10} \mathrm{H}_{8} \mathrm{NO}_{2}\left([\mathrm{M}+\mathrm{H}]^{+}\right)$: 174.0550; found: 174.0557 .

4-(But-3-en-1-yn-1-yl)benzonitrile (3g) $)^{13}$

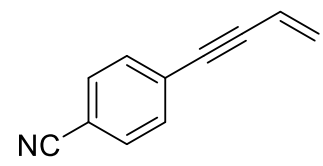

White solid (25.3 mg from Procedure B, 83\%; $25.8 \mathrm{mg}$ from Procedure D, 84 \%), a mixture of petroleum ether / ethyl acetate $=80 / 1(\mathrm{v} / \mathrm{v})$ as eluents for column chromatography. M.p.: 63.3-64.4 ${ }^{\circ} \mathrm{C} .{ }^{1} \mathrm{H}$ NMR $\left(500 \mathrm{MHz}, \mathrm{CDCl}_{3}\right) \delta 7.61(\mathrm{~d}, J=8.1$ $\mathrm{Hz}, 2 \mathrm{H}), 7.52(\mathrm{~d}, J=8.0 \mathrm{~Hz}, 2 \mathrm{H}), 6.03(\mathrm{dd}, J=17.5 \mathrm{~Hz}, 11.2 \mathrm{~Hz}, 1 \mathrm{H}), 5.81(\mathrm{dm}, J=$ $17.5 \mathrm{~Hz}, 1 \mathrm{H}), 5.65(\mathrm{dm}, J=11.2 \mathrm{~Hz}, 1 \mathrm{H}) .{ }^{13} \mathrm{C} \mathrm{NMR}\left(126 \mathrm{MHz}, \mathrm{CDCl}_{3}\right) \delta 132.1$, 132.0, 128.7, 128.1, 118.5, 116.6, 111.6, 92.3, 88.2. IR (KBr): 3093, 3056, 2221, 1925, 1858, 1734, 1669, 1606, 1499, 1405, 1267, 1178, 1105, 1019, 971, 927, $837 \mathrm{~cm}^{-1}$. HRMS-ESI $(\mathrm{m} / \mathrm{z})$ calcd. for $\mathrm{C}_{11} \mathrm{H}_{8} \mathrm{~N}\left([\mathrm{M}+\mathrm{H}]^{+}\right)$: 154.0651 ; found: 154.0653.

1-(4-(But-3-en-1-yn-1-yl)phenyl)ethan-1-one (3h) 


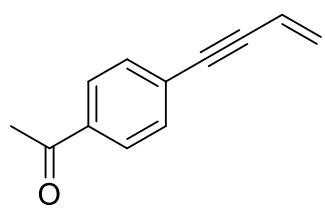

Yellow oil (32.1 mg from Procedure B (24 h), 94\%), a mixture of petroleum ether / ethyl acetate $=40 / 1(\mathrm{v} / \mathrm{v})$ as eluents for column chromatography. ${ }^{1} \mathrm{H}$ NMR (500 $\left.\mathrm{MHz}, \mathrm{CDCl}_{3}\right) \delta 7.90(\mathrm{~d}, J=8.4 \mathrm{~Hz}, 2 \mathrm{H}), 7.51(\mathrm{~d}, J=8.4 \mathrm{~Hz}, 2 \mathrm{H}), 6.03(\mathrm{dd}, J=17.5$ $\mathrm{Hz}, 11.2 \mathrm{~Hz}, 1 \mathrm{H}), 5.79(\mathrm{dd}, J=17.5 \mathrm{~Hz}, 1.9 \mathrm{~Hz}, 1 \mathrm{H}), 5.61$ (dd, $J=11.2 \mathrm{~Hz}, 1.9 \mathrm{~Hz}$, 1H), 2.59 (s, 3H). ${ }^{13} \mathrm{C}$ NMR (126 MHz, $\left.\mathrm{CDCl}_{3}\right) \delta 197.3,136.3,131.7,128.2,128.1$, 128.0, 116.8, 91.3, 89.1, 26.6. IR (KBr): 3057, 3006, 2956, 2925, 2855, 1728, 1687 , 1608, 1509, 1492, 1453, 1405, 1358, 1285, 1262, 1179, 1111, 1035, 968, 919, 840, $752 \mathrm{~cm}^{-1}$. HRMS-ESI $(\mathrm{m} / \mathrm{z})$ calcd. for $\mathrm{C}_{12} \mathrm{H}_{11} \mathrm{O}\left([\mathrm{M}+\mathrm{H}]^{+}\right)$: 171.0804; found: 171.0813 .

4-(But-3-en-1-yn-1-yl)- N,N-dimethylbenzamide (3i)

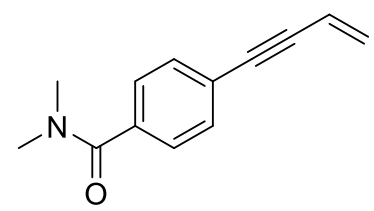

Yellow oil (31.2 mg from Procedure B (24 h), 78\%), a mixture of petroleum ether / ethyl acetate $=1 / 1(\mathrm{v} / \mathrm{v})$ as eluents for column chromatography. ${ }^{1} \mathrm{H}$ NMR $(500 \mathrm{MHz}$, $\left.\mathrm{CDCl}_{3}\right) \delta 7.46(\mathrm{~d}, J=8.2 \mathrm{~Hz}, 2 \mathrm{H}), 7.36(\mathrm{~d}, J=8.2 \mathrm{~Hz}, 2 \mathrm{H}), 6.01(\mathrm{dd}, J=17.5 \mathrm{~Hz}$, $11.3 \mathrm{~Hz}, 1 \mathrm{H}), 5.75$ (dd, $J=17.5 \mathrm{~Hz}, 1.9 \mathrm{~Hz}, 1 \mathrm{H}), 5.57$ (dd, $J=11.2 \mathrm{~Hz}, 1.9 \mathrm{~Hz}, 1 \mathrm{H})$, 3.09 (s, 3H), 2.96 (s, 3H). ${ }^{13} \mathrm{C}$ NMR (126 MHz, $\left.\mathrm{CDCl}_{3}\right) \delta 170.9,135.9,131.5,127.5$, 127.2, 124.5, 117.0, 89.4, 89.2, 39.5, 35.4. IR (KBr): 3040, 3010, 2926, 2855, 2218, 1634, 1512, 1490, 1450, 1394, 1265, 1217, 1076, 1018, 971, 919, 848, $763 \mathrm{~cm}^{-1}$. HRMS-ESI (m/z) calcd. for $\mathrm{C}_{13} \mathrm{H}_{14} \mathrm{NO}\left([\mathrm{M}+\mathrm{H}]^{+}\right)$: 200.1070; found: 200.1072.

4-(But-3-en-1-yn-1-yl)-1,1'-biphenyl (3j) $)^{14}$

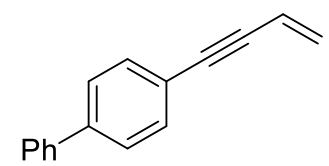

White solid (30.7 mg from Procedure B (24 h), 75\%; $32.0 \mathrm{mg}$ from Procedure D (24 h), 78\%), petroleum ether as eluent for column chromatography. M.p.: 61.8-62.3 ${ }^{\circ} \mathrm{C}$. ${ }^{1} \mathrm{H}$ NMR $\left(500 \mathrm{MHz}, \mathrm{CDCl}_{3}\right) \delta 7.61(\mathrm{~d}, J=7.9 \mathrm{~Hz}, 2 \mathrm{H}), 7.58-7.53(\mathrm{~m}, 4 \mathrm{H}), 7.46(\mathrm{t}, J$ 
$=7.6 \mathrm{~Hz}, 2 \mathrm{H}), 7.37(\mathrm{t}, J=7.7 \mathrm{~Hz}, 1 \mathrm{H}), 6.07(\mathrm{dd}, J=17.5 \mathrm{~Hz}, 11.2 \mathrm{~Hz}, 1 \mathrm{H}), 5.78(\mathrm{dm}$, $J=17.5 \mathrm{~Hz}, 1 \mathrm{H}), 5.58(\mathrm{dm}, J=11.2 \mathrm{~Hz}, 1 \mathrm{H}) .{ }^{13} \mathrm{C} \mathrm{NMR}\left(126 \mathrm{MHz}, \mathrm{CDCl}_{3}\right) \delta 141.0$, $140.4,132.0,128.9,127.7,127.0,127.0,126.9,122.1,117.3,89.9$, 88.8. IR (KBr): 3096, 3053, 3033, 3007, 1637, 1609, 1580, 1485, 1447, 1406, 1386, 1114, 1078, 970, 917, 839, 764, $695 \mathrm{~cm}^{-1}$. HRMS-ESI $(\mathrm{m} / \mathrm{z})$ calcd. for $\mathrm{C}_{16} \mathrm{H}_{13}\left([\mathrm{M}+\mathrm{H}]^{+}\right): 205.1012$; found: 205.1022 .

1-(But-3-en-1-yn-1-yl)-3-fluorobenzene (3k)

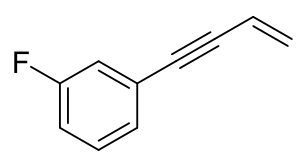

Colorless oil (20.1 mg from Procedure A, 67\%), pentane as eluent for column chromatography. ${ }^{1} \mathrm{H}$ NMR $\left(500 \mathrm{MHz}, \mathrm{CDCl}_{3}\right) \delta 7.29(\mathrm{~m}, 1 \mathrm{H}), 7.23(\mathrm{~d}, J=7.5 \mathrm{~Hz}$, 1H), $7.14(\mathrm{~d}, J=9.4 \mathrm{~Hz}, 1 \mathrm{H}), 7.03$ (t, $J=8.4 \mathrm{~Hz}, 1 \mathrm{H}), 6.02(\mathrm{dd}, J=17.6 \mathrm{~Hz}, 11.2 \mathrm{~Hz}$, 1H), $5.77(\mathrm{dm}, J=17.5 \mathrm{~Hz}, 1 \mathrm{H}), 5.59(\mathrm{dm}, J=11.2 \mathrm{~Hz}, 1 \mathrm{H}) .{ }^{19} \mathrm{~F}$ NMR $(471 \mathrm{MHz}$, $\left.\mathrm{CDCl}_{3}\right) \delta-113.02(\mathrm{~m}, 1 \mathrm{~F}) .{ }^{13} \mathrm{C} \mathrm{NMR}\left(126 \mathrm{MHz}, \mathrm{CDCl}_{3}\right) \delta 162.4(\mathrm{~d}, J=246.6 \mathrm{~Hz})$, $129.9(\mathrm{~d}, J=8.7 \mathrm{~Hz}), 127.6,127.5(\mathrm{~d}, J=3.0 \mathrm{~Hz}), 125.1(\mathrm{~d}, J=9.5 \mathrm{~Hz}), 118.3(\mathrm{~d}, J=$ $22.8 \mathrm{~Hz}), 116.9,115.6$ (d, $J=21.2 \mathrm{~Hz}), 88.9,88.7$ (d, $J=3.5 \mathrm{~Hz}) . \mathrm{IR}(\mathrm{KBr}): 3072$, 3012, 1854, 1611, 1579, 1486, 1436, 1285, 1264, 1176, 1153, 978, 922, 871, 853, 783, $680 \mathrm{~cm}^{-1}$. HRMS-ESI $(\mathrm{m} / \mathrm{z})$ calcd. for $\mathrm{C}_{10} \mathrm{H}_{8} \mathrm{~F}\left([\mathrm{M}+\mathrm{H}]^{+}\right)$: 147.0605; found: 147.0613.

Methyl 2-(but-3-en-1-yn-1-yl)benzoate (3l)

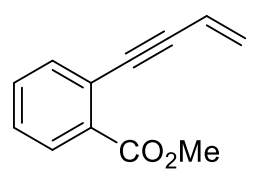

Light yellow oil (18.8 mg from Procedure B, 51\%; $25.6 \mathrm{mg}$ from Procedure D, $67 \%)$, a mixture of petroleum ether / ethyl acetate $=80 / 1(\mathrm{v} / \mathrm{v})$ as eluents for column chromatography. ${ }^{1} \mathrm{H}$ NMR $\left(500 \mathrm{MHz}, \mathrm{CDCl}_{3}\right) \delta 7.94(\mathrm{dd}, J=7.9 \mathrm{~Hz}, 1.0 \mathrm{~Hz}$, $1 \mathrm{H}), 7.56(\mathrm{dd}, J=7.7 \mathrm{~Hz}, 0.8 \mathrm{~Hz}, 1 \mathrm{H}), 7.46(\mathrm{td}, J=7.6 \mathrm{~Hz}, 1.2 \mathrm{~Hz}, 1 \mathrm{H}), 7.36(\mathrm{td}, J=$ $7.6 \mathrm{~Hz}, 1.0 \mathrm{~Hz}, 1 \mathrm{H}), 6.09$ (dd, $J=17.6 \mathrm{~Hz}, 11.2 \mathrm{~Hz}, 1 \mathrm{H}), 5.79$ (dd, $J=17.6 \mathrm{~Hz}, 2.0$ $\mathrm{Hz}, 1 \mathrm{H}), 5.59$ (dd, $J=11.2 \mathrm{~Hz}, 2.0 \mathrm{~Hz}, 1 \mathrm{H}), 3.93$ (s, 3H). ${ }^{13} \mathrm{C} \mathrm{NMR}\left(126 \mathrm{MHz}, \mathrm{CDCl}_{3}\right)$ $\delta 166.6,134.1,131.8,131.7,130.4,127.9,127.5,123.6,117.3,93.0,88.6,52.2$. IR (KBr): 3067, 3009, 2951, 2926, 2854, 1732, 1606, 1565, 1485, 1448, 1433, 1292 , 
1278, 1253, 1191, 1130, 1092, 1074, 969, 923, 823, 758, $700 \mathrm{~cm}^{-1}$. HRMS-ESI $(\mathrm{m} / \mathrm{z})$ calcd. for $\mathrm{C}_{12} \mathrm{H}_{11} \mathrm{O}_{2}\left([\mathrm{M}+\mathrm{H}]^{+}\right)$: 187.0754; found: 187.0758 .

1-(But-3-en-1-yn-1-yl)-4-ethoxybenzene (3m)

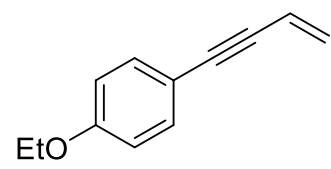

Light yellow oil (27.2 mg from Procedure B (at $40{ }^{\circ} \mathrm{C}$ for $24 \mathrm{~h}$ ), $79 \%$ ), petroleum ether as eluent for column chromatography. ${ }^{1} \mathrm{H} \mathrm{NMR}\left(500 \mathrm{MHz}, \mathrm{CDCl}_{3}\right) \delta 7.37(\mathrm{~d}, J$ $=8.4 \mathrm{~Hz}, 2 \mathrm{H}), 6.83(\mathrm{~d}, J=8.3 \mathrm{~Hz}, 2 \mathrm{H}), 6.01(\mathrm{dd}, J=17.5 \mathrm{~Hz}, 11.2 \mathrm{~Hz}, 1 \mathrm{H}), 5.69(\mathrm{dm}$, $J=17.5 \mathrm{~Hz}, 1 \mathrm{H}), 5.50(\mathrm{dm}, J=11.2 \mathrm{~Hz}, 1 \mathrm{H}), 4.04(\mathrm{q}, J=7.0 \mathrm{~Hz}, 2 \mathrm{H}), 1.42(\mathrm{t}, J=7.0$ $\mathrm{Hz}, 3 \mathrm{H}) .{ }^{13} \mathrm{C} \mathrm{NMR}\left(126 \mathrm{MHz}, \mathrm{CDCl}_{3}\right) \delta 159.0,133.0,126.0,117.4,115.0,114.5,90.1$, 86.8, 63.5, 14.8. IR (KBr): 3043, 2954, 2926, 2854, 2216, 1731, 1604, 1508, 1477, 1453, 1394, 1288, 1247, 1173, 1115, 1045, 970, 918, 835, $754 \mathrm{~cm}^{-1}$. HRMS-ESI (m/z) calcd. for $\mathrm{C}_{12} \mathrm{H}_{13} \mathrm{O}\left([\mathrm{M}+\mathrm{H}]^{+}\right)$: 173.0961; found: 173.0968 .

1-(But-3-en-1-yn-1-yl)-3-methoxybenzene (3n) ${ }^{15}$

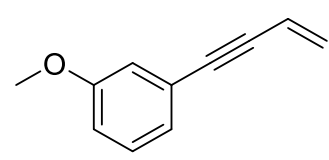

Light yellow oil (33.6 mg from Procedure B, 93\%; $29.2 \mathrm{mg}$ from Procedure D, $92 \%$ ), petroleum ether as eluent for column chromatography. ${ }^{1} \mathrm{H}$ NMR $(500 \mathrm{MHz}$, $\left.\mathrm{CDCl}_{3}\right) \delta 7.23(\mathrm{t}, J=8.0 \mathrm{~Hz}, 1 \mathrm{H}), 7.05(\mathrm{dm}, J=7.6 \mathrm{~Hz}, 1 \mathrm{H}), 6.99(\mathrm{~m}, 1 \mathrm{H}), 6.88(\mathrm{dd}, J$ $=8.2 \mathrm{~Hz}, 2.5 \mathrm{~Hz}, 1 \mathrm{H}), 6.02(\mathrm{dd}, J=17.5 \mathrm{~Hz}, 11.2 \mathrm{~Hz}, 1 \mathrm{H}), 5.75(\mathrm{dd}, J=17.5 \mathrm{~Hz}, 2.0$ $\mathrm{Hz}, 1 \mathrm{H}), 5.56(\mathrm{dd}, J=11.2 \mathrm{~Hz}, 2.0 \mathrm{~Hz}, 1 \mathrm{H}), 3.81$ (s, 3H). ${ }^{13} \mathrm{C} \mathrm{NMR}\left(126 \mathrm{MHz}, \mathrm{CDCl}_{3}\right)$ $\delta 159.3,129.4,127.0,124.2,124.1,117.2,116.3,115.0,89.9,87.9,55.3 . \mathrm{IR}(\mathrm{KBr})$ : 3074, 3007, 2956, 2925, 2854, 2206, 1731, 1608, 1597, 1575, 1489, 1480, 1464, 1422, 1318, 1290, 1211, 1177, 1166, 1047, 971, 919, 873, 853, 785, $686 \mathrm{~cm}^{-1}$. HRMS-ESI $(\mathrm{m} / \mathrm{z})$ calcd. for $\mathrm{C}_{11} \mathrm{H}_{11} \mathrm{O}\left([\mathrm{M}+\mathrm{H}]^{+}\right)$: 159.0804; found: 159.0811 .

1-(But-3-en-1-yn-1-yl)-2-methoxybenzene (3o $)^{15}$<smiles>C=CC#Cc1ccccc1OC</smiles> 
Light yellow oil (25.0 mg from Procedure B (at $40{ }^{\circ} \mathrm{C}$ for $24 \mathrm{~h}$ ), 79\%; $26.2 \mathrm{mg}$ from Procedure $\mathbf{D}\left(\mathrm{K}_{3} \mathrm{PO}_{4}(0.2 \mathrm{mmol})\right.$ as a base $\left.), 83 \%\right)$, petroleum ether as eluent for column chromatography. ${ }^{1} \mathrm{H}$ NMR $\left(500 \mathrm{MHz}, \mathrm{CDCl}_{3}\right) \delta 7.42(\mathrm{~d}, J=7.5 \mathrm{~Hz}, 1 \mathrm{H}), 7.29$ (t, $J=8.1 \mathrm{~Hz}, 1 \mathrm{H}), 6.92(\mathrm{t}, J=7.5 \mathrm{~Hz}, 1 \mathrm{H}), 6.88(\mathrm{~d}, J=8.4 \mathrm{~Hz}, 2 \mathrm{H}), 6.09$ (dd, $J=$ $17.5 \mathrm{~Hz}, 11.2 \mathrm{~Hz}, 1 \mathrm{H}), 5.75(\mathrm{dm}, J=17.2 \mathrm{~Hz}, 1 \mathrm{H}), 5.54(\mathrm{dm}, J=11.2 \mathrm{~Hz}, 1 \mathrm{H}), 3.89$ (s, 3H). ${ }^{13} \mathrm{C} \mathrm{NMR}\left(126 \mathrm{MHz}, \mathrm{CDCl}_{3}\right) \delta 158.8,132.6,128.8,125.6,119.4,116.4,111.3$, 109.6, 91.1, 85.2, 54.8. HRMS-ESI $(\mathrm{m} / \mathrm{z})$ calcd. for $\mathrm{C}_{11} \mathrm{H}_{11} \mathrm{O}\left([\mathrm{M}+\mathrm{H}]^{+}\right)$: 159.0804; found: 159.0808 .

1-(But-3-en-1-yn-1-yl)-2-ethylbenzene (3p)

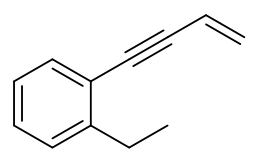

Colorless oil (18.5 mg from Procedure A (24 h), 59\%; $16.3 \mathrm{mg}$ from Procedure A (THF as a solvent for $24 \mathrm{~h}$ ), 52\%), pentane as eluent for column chromatography. ${ }^{1} \mathrm{H}$ NMR $\left(500 \mathrm{MHz}, \mathrm{CDCl}_{3}\right) \delta 7.43(\mathrm{~d}, J=7.6 \mathrm{~Hz}, 1 \mathrm{H}), 7.26(\mathrm{t}, J=7.6 \mathrm{~Hz}, 1 \mathrm{H}), 7.23(\mathrm{~d}$, $J=7.5 \mathrm{~Hz}, 2 \mathrm{H}), 7.15(\mathrm{t}, J=7.5 \mathrm{~Hz}, 1 \mathrm{H}), 6.07$ (dd, $J=17.6 \mathrm{~Hz}, 11.2 \mathrm{~Hz}, 1 \mathrm{H}), 5.73$ $(\mathrm{dm}, J=17.6 \mathrm{~Hz}, 1 \mathrm{H}), 5.55(\mathrm{dm}, J=11.2 \mathrm{~Hz}, 1 \mathrm{H}), 2.83(\mathrm{q}, J=7.6 \mathrm{~Hz}, 2 \mathrm{H}), 1.27(\mathrm{t}, J$ $=7.6 \mathrm{~Hz}, 3 \mathrm{H}) .{ }^{13} \mathrm{C} \mathrm{NMR}\left(126 \mathrm{MHz}, \mathrm{CDCl}_{3}\right) \delta 146.2,132.2,128.6,127.9,126.4$, 125.6, 122.2, 117.4, 91.5, 88.7, 27.7, 14.8. IR (KBr): 3098, 3066, 3010, 2967, 2929, 2872, 2855, 1605, 1484, 1447, 1410, 1373, 1290, 1121, 1051, 969, 917, $756 \mathrm{~cm}^{-1}$. HRMS-ESI $(\mathrm{m} / \mathrm{z})$ calcd. for $\mathrm{C}_{12} \mathrm{H}_{13}\left([\mathrm{M}+\mathrm{H}]^{+}\right)$: 157.1012; found: 157.1013 .

3-(But-3-en-1-yn-1-yl)thiophene (3q) $)^{15}$

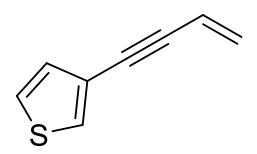

Light yellow oil (22.2 mg from Procedure A, 83\%; $17.9 \mathrm{mg}$ from Procedure A (24 h), 67\%; $26.3 \mathrm{mg}$ from Procedure C, 98\%), pentane as eluent for column chromatography. ${ }^{1} \mathrm{H} \mathrm{NMR}\left(500 \mathrm{MHz}, \mathrm{CDCl}_{3}\right) \delta 7.45(\mathrm{dd}, J=2.9 \mathrm{~Hz}, 0.8 \mathrm{~Hz}, 1 \mathrm{H})$, $7.27(\mathrm{dd}, J=5.0 \mathrm{~Hz}, 3.0 \mathrm{~Hz}, 1 \mathrm{H}), 7.12(\mathrm{dd}, J=5.0 \mathrm{~Hz}, 0.9 \mathrm{~Hz}, 1 \mathrm{H}), 6.00$ (dd, $J=17.6$ $\mathrm{Hz}, 11.2 \mathrm{~Hz}, 1 \mathrm{H}), 5.72(\mathrm{dd}, J=17.5 \mathrm{~Hz}, 2.0 \mathrm{~Hz}, 1 \mathrm{H}), 5.54$ (dd, $J=11.2 \mathrm{~Hz}, 2.0 \mathrm{~Hz}$, 1H). ${ }^{13} \mathrm{C} \mathrm{NMR}\left(126 \mathrm{MHz}, \mathrm{CDCl}_{3}\right) \delta 129.8,128.7,126.8,125.3,122.2,117.1,87.7$, 
85.1. IR (KBr): 3107, 3007, 2218, 2198, 1604, 1464, 1356, 1185, 1074, 970, 918, 854, $779 \mathrm{~cm}^{-1}$. HRMS-ESI $(\mathrm{m} / \mathrm{z})$ calcd. for $\mathrm{C}_{8} \mathrm{H}_{7} \mathrm{~S}\left([\mathrm{M}+\mathrm{H}]^{+}\right): 135.0263$; found: 135.0270 .

6-(But-3-en-1-yn-1-yl)-4,4-dimethylthiochromane (3r)

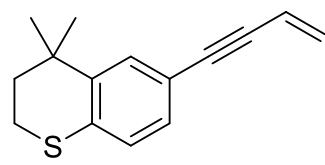

Light yellow oil (43.5 mg from Procedure B, 95\%; $42.4 \mathrm{mg}$ from Procedure D, 93\%), a mixture of hexane / ethyl acetate $=200 / 1(\mathrm{v} / \mathrm{v})$ as eluents for column chromatography. ${ }^{1} \mathrm{H} \mathrm{NMR}\left(500 \mathrm{MHz}, \mathrm{CDCl}_{3}\right) \delta 7.44(\mathrm{~s}, 1 \mathrm{H}), 7.10(\mathrm{~d}, J=8.1 \mathrm{~Hz}, 1 \mathrm{H})$, $7.03(\mathrm{~d}, J=8.2 \mathrm{~Hz}, 1 \mathrm{H}), 6.02(\mathrm{dd}, J=17.5 \mathrm{~Hz}, 11.2 \mathrm{~Hz}, 1 \mathrm{H}), 5.71(\mathrm{dm}, J=17.5 \mathrm{~Hz}$, $1 \mathrm{H}), 5.52(\mathrm{dm}, J=11.2 \mathrm{~Hz}, 1 \mathrm{H}), 3.04(\mathrm{t}, J=6.0 \mathrm{~Hz}, 2 \mathrm{H}), 1.94(\mathrm{t}, J=6.1 \mathrm{~Hz}, 2 \mathrm{H})$, $1.32(\mathrm{~s}, 6 \mathrm{H}) .{ }^{13} \mathrm{C} \mathrm{NMR}\left(126 \mathrm{MHz}, \mathrm{CDCl}_{3}\right) \delta 142.0,133.1,129.7,128.9,126.5,126.3$, 118.4, 117.3, 90.4, 87.4, 37.3, 33.0, 30.0, 23.2. IR (KBr): 3097, 3049, 3006, 2960, 2935, 2869, 2222, 2193, 1838, 1608, 1589, 1541, 1474, 1450, 1387, 1364, 1292, 1248 , 1176, 1115, 1056, 969, 917, 889, $818 \mathrm{~cm}^{-1}$. HRMS-ESI (m/z) calcd. for $\mathrm{C}_{15} \mathrm{H}_{17} \mathrm{~S}([\mathrm{M}$ $+\mathrm{H}]^{+}$): 229.1045; found: 229.1048 .

3-(But-3-en-1-yn-1-yl)-1-tosyl-1H-indole (3s)

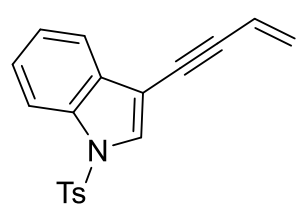

White solid (50.4 mg from Procedure B, 78\%), a mixture of petroleum ether / ethyl acetate $=40 / 1(\mathrm{v} / \mathrm{v})$ as eluents for column chromatography. M.p.: 126.8-128.6 ${ }^{\circ} \mathrm{C}$. ${ }^{1} \mathrm{H}$ NMR (500 MHz, $\left.\mathrm{CDCl}_{3}\right) \delta 7.99(\mathrm{~d}, J=8.3 \mathrm{~Hz}, 1 \mathrm{H}), 7.78(\mathrm{~d}, J=8.4 \mathrm{~Hz}, 2 \mathrm{H}), 7.75$ (s, 1H), $7.65(\mathrm{~d}, J=7.8 \mathrm{~Hz}, 1 \mathrm{H}), 7.36(\mathrm{tm}, J=7.8 \mathrm{~Hz}, 1 \mathrm{H}), 7.30(\mathrm{tm}, J=7.7 \mathrm{~Hz}, 1 \mathrm{H})$, $7.22(\mathrm{~d}, J=8.2 \mathrm{~Hz}, 2 \mathrm{H}), 6.07(\mathrm{dd}, J=17.5 \mathrm{~Hz}, 11.2 \mathrm{~Hz}, 1 \mathrm{H}), 5.78(\mathrm{dd}, J=17.5 \mathrm{~Hz}$, $1.9 \mathrm{~Hz}, 1 \mathrm{H}), 5.58(\mathrm{dd}, J=11.2 \mathrm{~Hz}, 2.0 \mathrm{~Hz}, 1 \mathrm{H}), 2.33(\mathrm{~s}, 3 \mathrm{H}) .{ }^{13} \mathrm{C}$ NMR $(126 \mathrm{MHz}$, $\left.\mathrm{CDCl}_{3}\right) \delta 145.4,134.9,134.3,130.7,130.0,128.8,127.1,126.9,125.5,123.8,120.6$, 117.0, 113.6, 105.2, 92.3, 81.0, 21.6. IR (KBr): 3123, 3077, 3056, 2958, 2924, 2848, 2198, 1920, 1732, 1607, 1595, 1545, 1492, 1447, 1379, 1283, 1232, 1178, 1107, 983, 814, 761, 710, $662 \mathrm{~cm}^{-1}$. HRMS-ESI $(\mathrm{m} / \mathrm{z})$ calcd. for $\mathrm{C}_{19} \mathrm{H}_{16} \mathrm{NO}_{2} \mathrm{~S}\left([\mathrm{M}+\mathrm{H}]^{+}\right)$: 322.0896; found: 322.0902 . 
(Bent-4-en-2-yn-1-yloxy)benzene (3t)

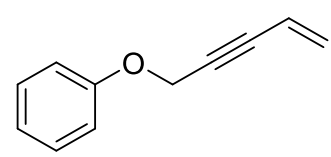

Light yellow oil (15.8 mg from Procedure B, 50\%; $15.8 \mathrm{mg}$ from Procedure D, $50 \%)$, a mixture of petroleum ether / ethyl acetate $=80 / 1(\mathrm{v} / \mathrm{v})$ as eluents for column chromatography. ${ }^{1} \mathrm{H}$ NMR $\left(500 \mathrm{MHz}, \mathrm{CDCl}_{3}\right) \delta 7.32(\mathrm{t}, J=7.1 \mathrm{~Hz}, 2 \mathrm{H})$, 7.01-6.98 (m, 3H), $5.83(\mathrm{dd}, J=17.6 \mathrm{~Hz}, 11.1 \mathrm{~Hz}, 1 \mathrm{H}), 5.69$ (dd, $J=17.6 \mathrm{~Hz}, 1.7 \mathrm{~Hz}$, $1 \mathrm{H}), 5.52(\mathrm{dd}, J=11.1 \mathrm{~Hz}, 1.8 \mathrm{~Hz}, 1 \mathrm{H}), 4.82(\mathrm{~d}, J=1.3 \mathrm{~Hz}, 2 \mathrm{H}) .{ }^{13} \mathrm{C} \mathrm{NMR}(126 \mathrm{MHz}$, $\left.\mathrm{CDCl}_{3}\right) \delta 157.7,129.5,128.1,121.4,116.4,114.9,85.8,84.5,56.4 . \mathrm{IR}(\mathrm{KBr}): 3063$, 3041, 2923, 2858, 1599, 1588, 1495, 1457, 1375, 1303, 1262, 1238, 1215, 1174, 1160, 1040, 1008, 992, 927, 753, $690 \mathrm{~cm}^{-1}$. HRMS-ESI $(\mathrm{m} / \mathrm{z})$ calcd. for $\mathrm{C}_{11} \mathrm{H}_{11} \mathrm{O}\left([\mathrm{M}+\mathrm{H}]^{+}\right)$: 159.0804; found: 159.0805 .

Bent-4-en-2-yn-1-yl benzoate (3u)

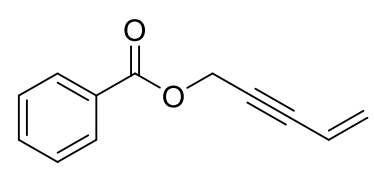

Colorless oil (21.1 mg from Procedure B, 57\%; $21.0 \mathrm{mg}$ from Procedure D, 56\%), a mixture of petroleum ether / ethyl acetate $=80 / 1(\mathrm{v} / \mathrm{v})$ as eluents for column chromatography. ${ }^{1} \mathrm{H}$ NMR $\left(500 \mathrm{MHz}, \mathrm{CDCl}_{3}\right) \delta 8.09(\mathrm{~d}, J=7.6 \mathrm{~Hz}, 2 \mathrm{H}), 7.58(\mathrm{t}, J=$ $7.4 \mathrm{~Hz}, 1 \mathrm{H}), 7.46$ (t, $J=7.8 \mathrm{~Hz}, 2 \mathrm{H}), 5.84(\mathrm{ddt}, J=17.6 \mathrm{~Hz}, 11.1 \mathrm{~Hz}, 1.9 \mathrm{~Hz}, 1 \mathrm{H}$ ), $5.72(\mathrm{dd}, J=17.6 \mathrm{~Hz}, 2.1 \mathrm{~Hz}, 1 \mathrm{H}), 5.55(\mathrm{dd}, J=11.1 \mathrm{~Hz}, 2.1 \mathrm{~Hz}, 1 \mathrm{H}), 5.05(\mathrm{~d}, J=1.8$ $\mathrm{Hz}, 2 \mathrm{H}) .{ }^{13} \mathrm{C} \mathrm{NMR}\left(126 \mathrm{MHz}, \mathrm{CDCl}_{3}\right) \delta 165.9,133.3,129.8,129.6,128.4,128.3$, 116.4, 85.2, 83.7, 53.2. IR (KBr): 3063, 2930, 2854, 1726, 1601, 1585, 1452, 1434, 1370, 1315, 1268, 1172, 1107, 1096, 1070, 1026, 950, $710 \mathrm{~cm}^{-1}$. HRMS-ESI (m/z) calcd. for $\mathrm{C}_{12} \mathrm{H}_{11} \mathrm{O}_{2}\left([\mathrm{M}+\mathrm{H}]^{+}\right)$: 187.0754; found: 187.0757 .

4-(Hex-5-en-3-yn-1-yl)benzonitrile (3v)

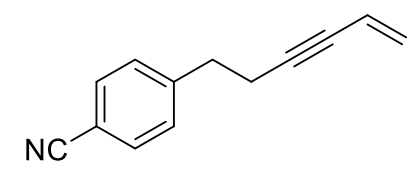

Colorless oil (22.2 mg from Procedure B (THF as a solvent at $40{ }^{\circ} \mathrm{C}$ for $24 \mathrm{~h}$ ), $61 \%$ ), a mixture of hexane / ethyl acetate $=20 / 1(\mathrm{v} / \mathrm{v})$ as eluents for preparative TLC plate. 
${ }^{1} \mathrm{H}$ NMR (500 MHz, $\left.\mathrm{CDCl}_{3}\right) \delta 7.60(\mathrm{~d}, J=7.7 \mathrm{~Hz}, 2 \mathrm{H}), 7.34(\mathrm{~d}, J=7.7 \mathrm{~Hz}, 2 \mathrm{H}), 5.74$ $(\mathrm{dd}, J=17.5 \mathrm{~Hz}, 11.1 \mathrm{~Hz}, 1 \mathrm{H}), 5.53(\mathrm{~d}, J=17.4 \mathrm{~Hz}, 1 \mathrm{H}), 5.40(\mathrm{~d}, J=11.1 \mathrm{~Hz}, 1 \mathrm{H})$, $2.90(\mathrm{t}, J=7.2 \mathrm{~Hz}, 2 \mathrm{H}), 2.62(\mathrm{t}, J=7.0 \mathrm{~Hz}, 2 \mathrm{H}) .{ }^{13} \mathrm{C} \mathrm{NMR}\left(126 \mathrm{MHz}, \mathrm{CDCl}_{3}\right) \delta$ 146.0, 132.2, 129.4, 126.2, 119.0, 117.2, 110.3, 89.0, 80.7, 35.0, 20.9. IR (KBr): 3099, 3038, 3009, 2955, 2930, 2865, 2228, 1725, 1608, 1506, 1450, 1430, 1413, 1339, 1290, 1178, 1021, 974, 920, $823 \mathrm{~cm}^{-1}$. HRMS-ESI $(\mathrm{m} / \mathrm{z})$ calcd. for $\mathrm{C}_{13} \mathrm{H}_{12} \mathrm{~N}\left([\mathrm{M}+\mathrm{H}]^{+}\right)$: 182.0964; found: 182.0971 .

$N$-benzyl- $N$-methylpent-4-en-2-yn-1-amine (3w)<smiles>C=CC#CCN(C)Cc1ccccc1</smiles>

Light yellow oil (18.0 mg from Procedure B, 49\%; $17.5 \mathrm{mg}$ from Procedure D, $47 \%$ ), a mixture of petroleum ether / ethyl acetate $=80 / 1$ (v / v) as eluents for preparative TLC plate. ${ }^{1} \mathrm{H}$ NMR $\left(500 \mathrm{MHz}, \mathrm{CDCl}_{3}\right) \delta 7.35-7.31(\mathrm{~m}, 4 \mathrm{H}), 7.26(\mathrm{t}, J=$ $7.6 \mathrm{~Hz}, 1 \mathrm{H}), 5.86(\mathrm{ddm}, J=17.5 \mathrm{~Hz}, 11.1 \mathrm{~Hz}, 1 \mathrm{H}), 5.66(\mathrm{dm}, J=17.5 \mathrm{~Hz}, 1 \mathrm{H}), 5.48$ $(\mathrm{dm}, J=11.1 \mathrm{~Hz}, 1 \mathrm{H}), 3.58(\mathrm{~s}, 2 \mathrm{H}), 3.42(\mathrm{~s}, 2 \mathrm{H}), 2.35(\mathrm{~s}, 3 \mathrm{H}) .{ }^{13} \mathrm{C}$ NMR $(126 \mathrm{MHz}$, $\left.\mathrm{CDCl}_{3}\right) \delta 138.5,129.2,128.3,127.2,126.6,117.1,85.3,84.3,60.3,45.7,41.9$. IR (KBr): 3063, 3028, 2939, 2838, 2793, 1842, 1606, 1495, 1454, 1365, 1327, 1146, 1125, 1026, 974, 919, 854, 739, $699 \mathrm{~cm}^{-1}$. HRMS-ESI (m/z) calcd. for $\mathrm{C}_{13} \mathrm{H}_{16} \mathrm{~N}([\mathrm{M}+$ $\left.\mathrm{H}]^{+}\right)$: 186.1277; found: 186.1290 .

\section{A scale-up synthesis of $3 f$ from $1 f$ and $2 a$}

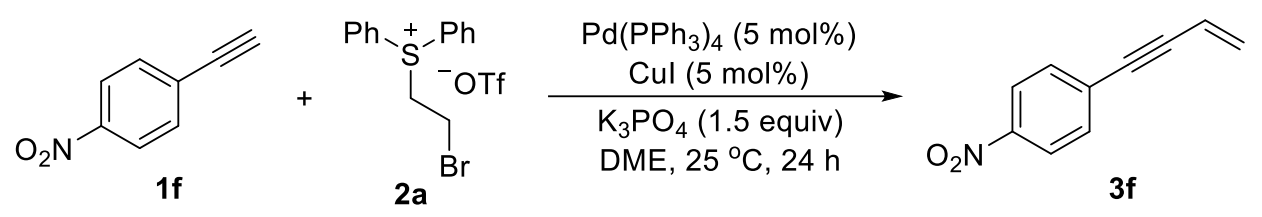

In a nitrogen filled glovebox, a sealed Schlenk flask $(50 \mathrm{~mL})$ was charged with $\mathrm{Pd}\left(\mathrm{PPh}_{3}\right)_{4}(58.0 \mathrm{mg}, 0.05 \mathrm{mmol}), \mathrm{CuI}(9.5 \mathrm{mg}, 0.05 \mathrm{mmol}), 2 \mathbf{a}(665.0 \mathrm{mg}, 1.5 \mathrm{mmol})$, 1-ethynyl-4-nitrobenzene (1f, $147.0 \mathrm{mg}, 1.0 \mathrm{mmol}), \mathrm{K}_{3} \mathrm{PO}_{4}(318.5 \mathrm{mg}, 1.5 \mathrm{mmol})$, and DME (10 mL) with vigorous stirring. The mixture was reacted at $25{ }^{\circ} \mathrm{C}$ for $24 \mathrm{~h}$, filtered through a celite pad, and washed with ethyl acetate $(2 \times 10 \mathrm{~mL})$. The filtrates were concentrated to dryness under reduced pressure. The residue was purified by column chromatography on silica gel using petroleum ether as eluent to give 136.2 mg of $\mathbf{3 f}$ (79\% yield, light yellow solid). 
7. General procedures for vinylation of terminal alkyne (1) with diphenyl(vinyl) sulfonium triflate $(2 \mathrm{~b})$.

Procedure A (for products with low boiling points only): In a nitrogen filled glovebox, a sealed tube was charged with $\mathrm{Pd}\left(\mathrm{PPh}_{3}\right)_{4}(0.01 \mathrm{mmol}), \mathrm{CuI}(0.01 \mathrm{mmol})$, diphenyl(vinyl)sulfonium triflate $(\mathbf{2 b}, 87.0 \mathrm{mg}, 0.24 \mathrm{mmol})$, terminal alkyne $(\mathbf{1}, 0.2$ $\mathrm{mmol}), \mathrm{K}_{3} \mathrm{PO}_{4}(42.5 \mathrm{mg}, 0.2 \mathrm{mmol})$, and DME $(2 \mathrm{~mL})$ with vigorous stirring. The mixture was reacted at $25{ }^{\circ} \mathrm{C}$ for $12 \mathrm{~h}$, diluted with diethyl ether $(10 \mathrm{~mL})$, and washed with $\mathrm{H}_{2} \mathrm{O}(15 \mathrm{~mL})$. The aqueous solution was extracted with diethyl ether $(10 \mathrm{~mL})$. The combined organic layers were dried over anhydrous $\mathrm{Na}_{2} \mathrm{SO}_{4}$ and concentrated to dryness under reduced pressure at ca. $10{ }^{\circ} \mathrm{C}$. The residue was purified by column chromatography on silica gel using pentane as eluent to give the desired product (3).

Procedure B: In a nitrogen filled glovebox, a sealed tube was charged with $\mathrm{Pd}\left(\mathrm{PPh}_{3}\right)_{4}$ (0.01 mmol), CuI (0.01 mmol), diphenyl(vinyl)sulfonium triflate (2b, $87.0 \mathrm{mg}, 0.24$ mmol), terminal alkyne (1, $0.2 \mathrm{mmol}), \mathrm{K}_{3} \mathrm{PO}_{4}(42.5 \mathrm{mg}, 0.2 \mathrm{mmol})$, and DME (2 mL) with vigorous stirring. The mixture was reacted at $25^{\circ} \mathrm{C}$ for $12 \mathrm{~h}$ and concentrated to dryness under reduced pressure. The residue was purified by column chromatography on silica gel using petroleum ether or a mixture of petroleum ether and ethyl acetate as eluents to give the desired product (3).

\begin{tabular}{|c|c|}
\hline Product & Isolated yield \\
\hline & $15.1 \mathrm{mg}$ from Procedure A, 59\% \\
\hline $3 \mathbf{3 c}$ & $25.4 \mathrm{mg}$ from Procedure A, $75 \%$ \\
\hline
\end{tabular}




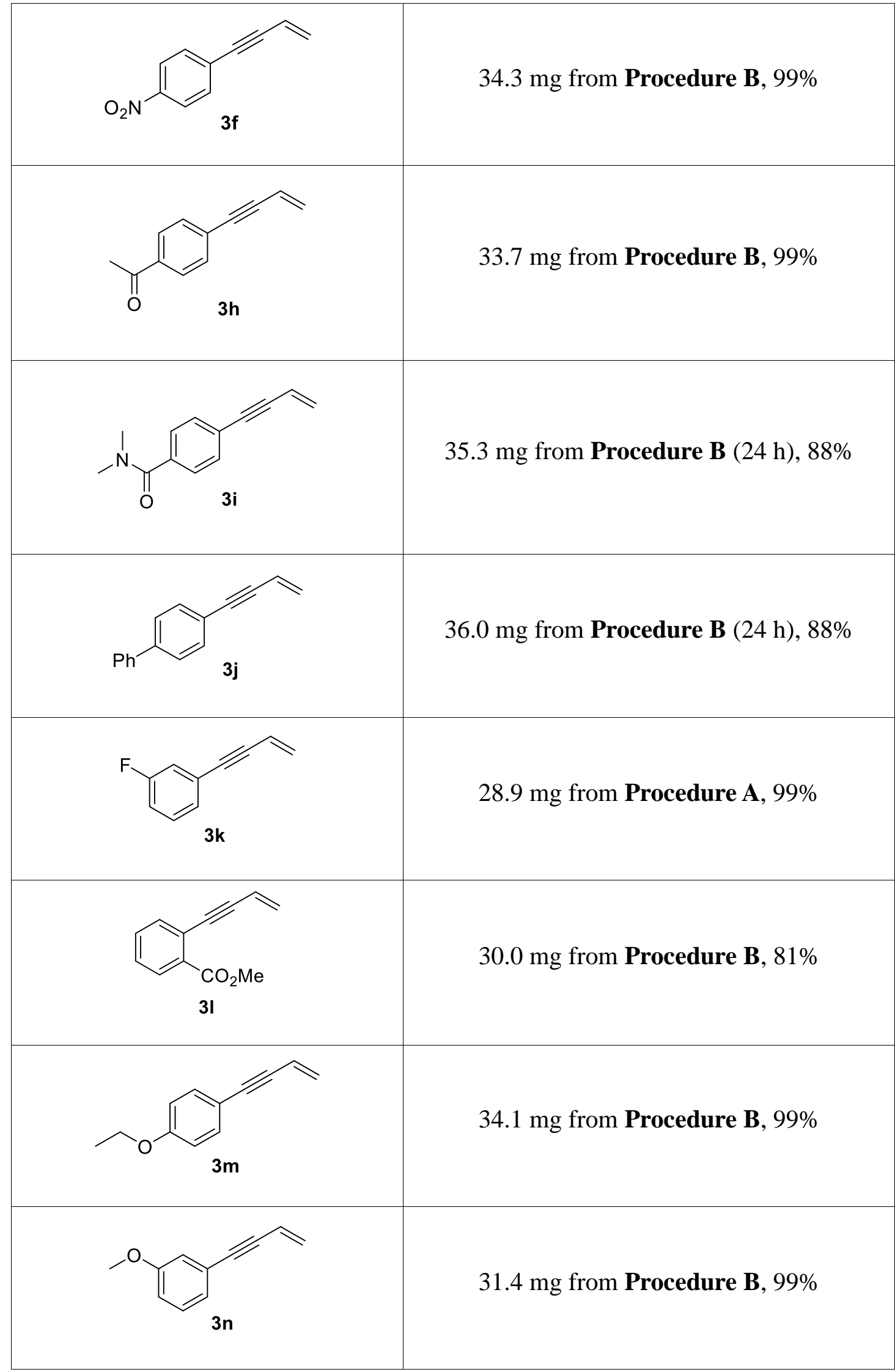




\begin{tabular}{|l|l|}
\hline & $29.4 \mathrm{mg}$ from Procedure $\mathbf{B}, 93 \%$ \\
\hline & $25.6 \mathrm{mg}$ from Procedure A, 96\% \\
\hline & \\
\hline
\end{tabular}

\section{A scale-up synthesis of $3 f$ from $1 f$ and $2 b$}

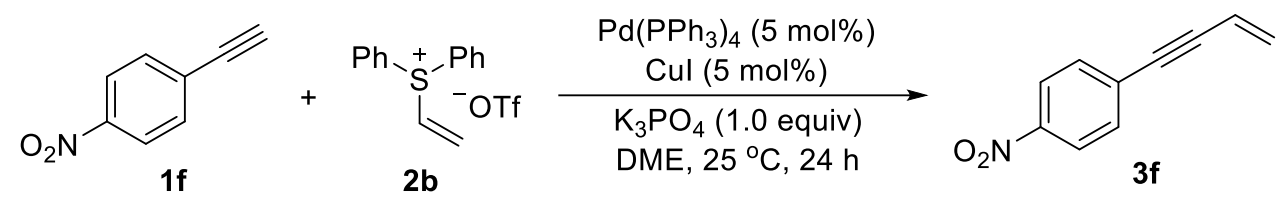

In a nitrogen filled glovebox, a sealed Schlenk flask $(50 \mathrm{~mL})$ was charged with $\mathrm{Pd}\left(\mathrm{PPh}_{3}\right)_{4}(58.0 \mathrm{mg}, 0.05 \mathrm{mmol}), \mathrm{CuI}(9.5 \mathrm{mg}, 0.05 \mathrm{mmol}), 2 \mathbf{b}$ (435 mg, $\left.1.2 \mathrm{mmol}\right)$, 1-ethynyl-4-nitrobenzene (1f, $147.0 \mathrm{mg}, 1.0 \mathrm{mmol}), \mathrm{K}_{3} \mathrm{PO}_{4}(212.0 \mathrm{mg}, 1.0 \mathrm{mmol})$, and DME $(10 \mathrm{~mL})$ with vigorous stirring. The mixture was reacted at $25{ }^{\circ} \mathrm{C}$ for $24 \mathrm{~h}$, filtered through a celite pad, and washed with ethyl acetate $(2 \times 10 \mathrm{~mL})$. The filtrates were concentrated to dryness under reduced pressure. The residue was purified by column chromatography on silica gel using petroleum ether as eluent to give 146.0 $\mathrm{mg}$ of $\mathbf{3 f}(84 \%$, light yellow solid). 
8. Vinylation of 1-ethynyl-4-nitrobenzene (1f) with $2 \mathrm{~b}$ in the presence of different additives under standard conditions. ${ }^{a}$

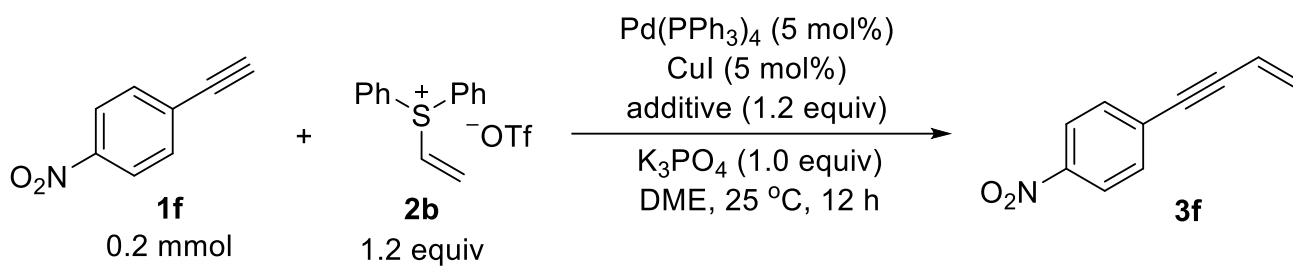

\begin{tabular}{ccc}
\hline Entry & Additive & Yield (3f, \%) \\
\hline 1 & - & $99^{b}$ \\
2 & $\mathrm{KCl}$ & 96 \\
3 & $\mathrm{KF}$ & 92 \\
4 & $\mathrm{KBr}$ & 96 \\
5 & $\mathrm{KI}$ & $16\left(24^{c}\right)$ \\
6 & $\mathrm{TsONa}$ & $>99$ \\
$7^{d}$ & - & 98 \\
$8^{d, e}$ & - & 38
\end{tabular}

${ }^{a}$ Reaction conditions: $\mathrm{Pd}\left(\mathrm{PPh}_{3}\right)_{4}(5 \mathrm{~mol} \%), \mathrm{CuI}(5 \mathrm{~mol} \%), \mathbf{1 f}(0.2 \mathrm{mmol}), 2 \mathbf{b}(0.24$ $\mathrm{mmol}), \mathrm{K}_{3} \mathrm{PO}_{4}(0.2 \mathrm{mmol})$, additive $(0.24 \mathrm{mmol})$, DME $(2 \mathrm{~mL}), 25^{\circ} \mathrm{C}, \mathrm{N}_{2}$, and $12 \mathrm{~h}$. The yields were determined by HPLC using $\mathbf{3 f}$ as an external standard $\left(\mathrm{t}_{\mathrm{R}}=8.490 \mathrm{~min}\right.$, $\lambda_{\max }=312 \mathrm{~nm}$, water $/$ methanol $\left.=20 / 80(\mathrm{v} / \mathrm{v})\right) . \quad{ }^{b}$ Isolated yield. $\quad{ }^{c}$ The recovery of 1f, which was determined by HPLC using $\mathbf{1 f}$ as an external standard $\left(\mathrm{t}_{\mathrm{R}}=\right.$ $5.37 \mathrm{~min}, \lambda_{\max }=312 \mathrm{~nm}$, water $/$ methanol $\left.=20 / 80(\mathrm{v} / \mathrm{v})\right) . \quad{ }^{d}$ The reaction was run in air. $e$ (2-Bromoethyl)diphenylsulfonium triflate $(\mathbf{2 a}, 0.3 \mathrm{mmol})$ and $\mathrm{K}_{3} \mathrm{PO}_{4}(0.3$ $\mathrm{mmol})$ were used instead of $\mathbf{2 b}(0.24 \mathrm{mmol})$ and $\mathrm{K}_{3} \mathrm{PO}_{4}(0.2 \mathrm{mmol})$, respectively.

\section{Reactions of different (2-haloethyl)sulfonium triflates or (2-(tosyloxy)ethyl)} sulfonium triflate with $\mathrm{KHCO}_{3}$.

Procedure: (2-haloethyl)sulfonium triflate or (2-(tosyloxy)ethyl)sulfonium triflate $(0.2 \mathrm{mmol})$ was dissolved into $\mathrm{THF} / \mathrm{H}_{2} \mathrm{O}(2 / 1(\mathrm{v} / \mathrm{v}), 1.5 \mathrm{~mL})$ and $\mathrm{KHCO}_{3}(38.1 \mathrm{mg}$, $0.38 \mathrm{mmol}, 1.9$ equiv) was added. The mixture was reacted at $25{ }^{\circ} \mathrm{C}$ for 25 mins, diluted with DCM $(20 \mathrm{~mL})$, dried over anhydrous $\mathrm{Na}_{2} \mathrm{SO}_{4}$, and concentrated to dryness under reduced pressure. The residue was purified by column chromatography 
on silica gel using a mixture of $\mathrm{DCM} / \mathrm{MeCN}=3 / 1(\mathrm{v} / \mathrm{v})$ as eluents to give diphenyl(vinyl)sulfonium triflate (2b) or unknown products.

1) In the reaction of (2-bromoethyl)diphenylsulfonium triflate (2a) with $\mathrm{KHCO}_{3}$, $70.3 \mathrm{mg}$ of $\mathbf{2 b}$ was obtained as a light yellow oil (97\%).

Figure S1. NMR spectra of the above product.
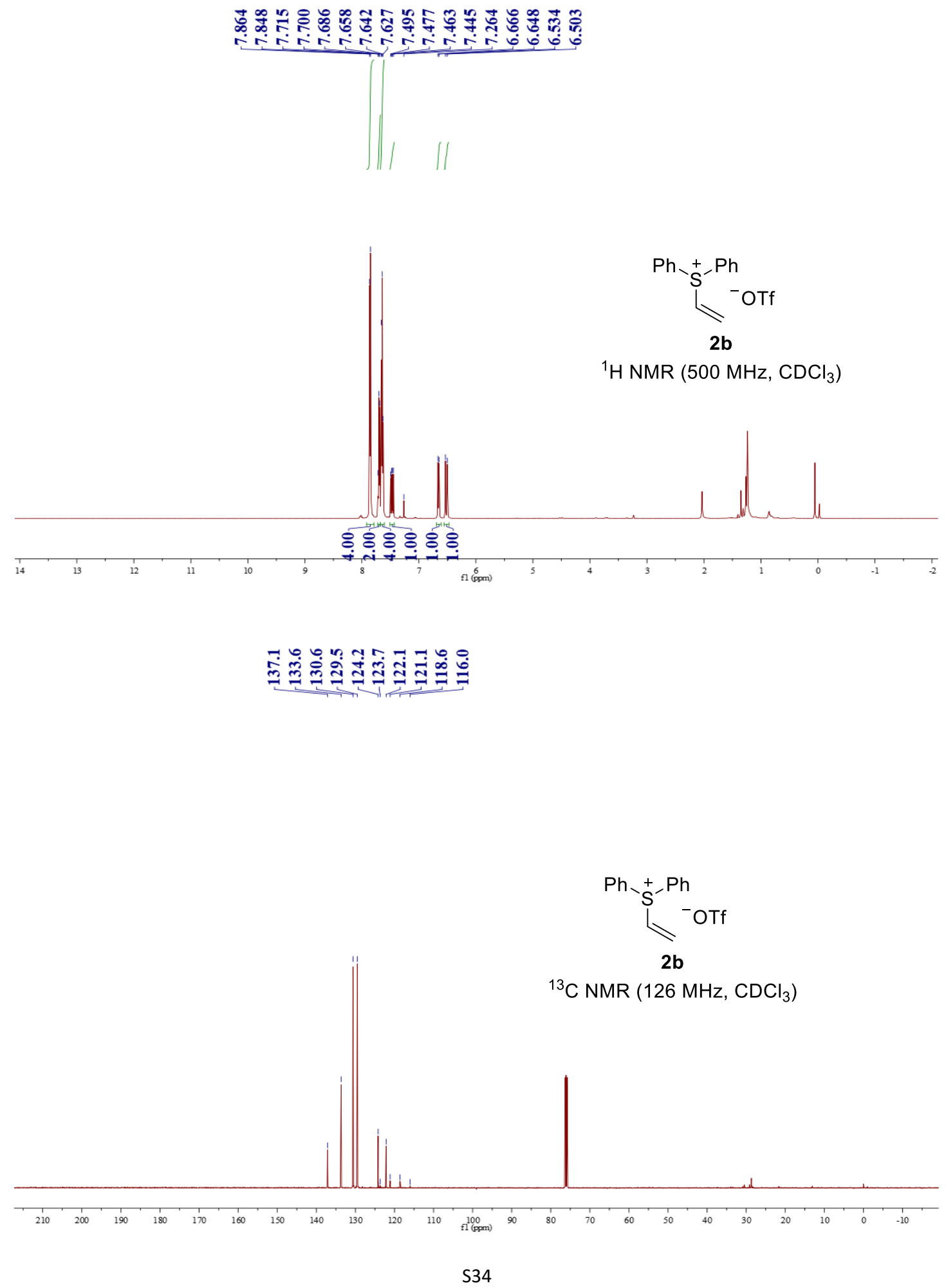
2) In the reaction of (2-fluoroethyl)diphenylsulfonium triflate (2c) with $\mathrm{KHCO}_{3}, 58.3$ $\mathrm{mg}$ of $\mathbf{2} \mathbf{b}$ was obtained as a light yellow oil $(80 \%)$.

Figure S2. ${ }^{1} \mathrm{H}$ NMR spectrum of the above product.
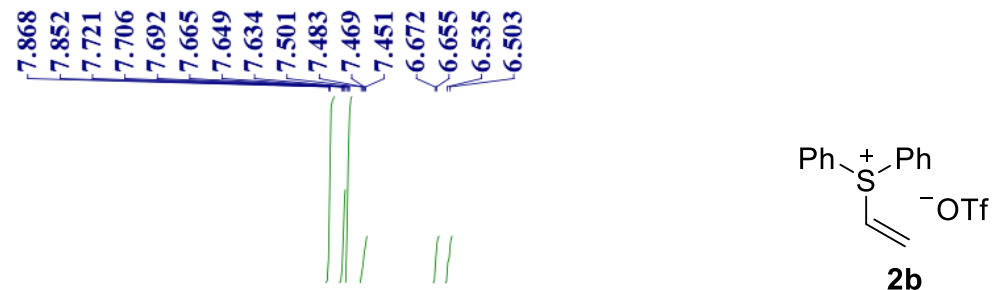

2b

${ }^{1} \mathrm{H}$ NMR $\left(500 \mathrm{MHz}, \mathrm{CDCl}_{3}\right)$

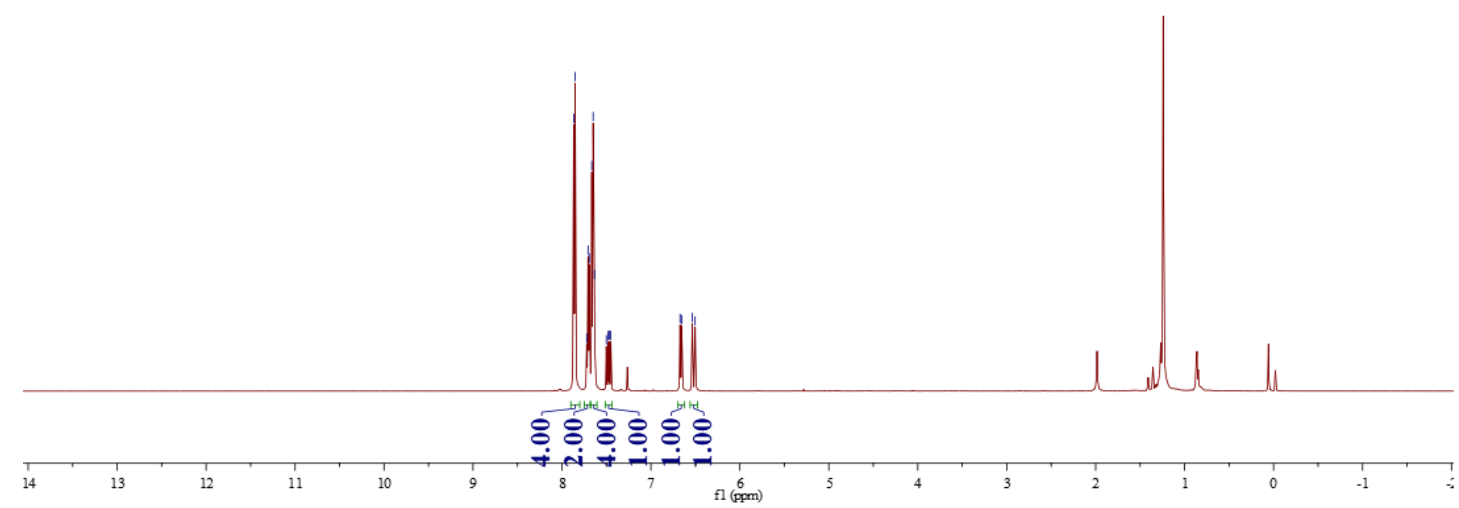

3) In the reaction of (2-chloroethyl)diphenylsulfonium triflate (2d) with $\mathrm{KHCO}_{3}$, $45.4 \mathrm{mg}$ of unknown product was obtained as a light brown oil. ${ }^{1} \mathrm{H}$ NMR (500 $\left.\mathrm{MHz}, \mathrm{CDCl}_{3}\right) \delta 7.91(\mathrm{~d}, J=7.8 \mathrm{~Hz}, 4 \mathrm{H}), 7.73(\mathrm{t}, J=7.4 \mathrm{~Hz}, 2 \mathrm{H}), 7.69-7.62(\mathrm{~m}$, $5 \mathrm{H}), 6.71(\mathrm{dm}, J=8.7 \mathrm{~Hz}, 1 \mathrm{H}), 6.55(\mathrm{dm}, J=15.9 \mathrm{~Hz}, 1 \mathrm{H})$.

Figure S3. ${ }^{1} \mathrm{H}$ NMR spectrum of the above product. 


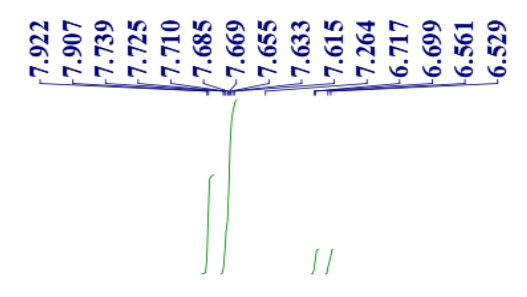

unknown product

${ }^{1} \mathrm{H}$ NMR $\left(500 \mathrm{MHz}, \mathrm{CDCl}_{3}\right)$

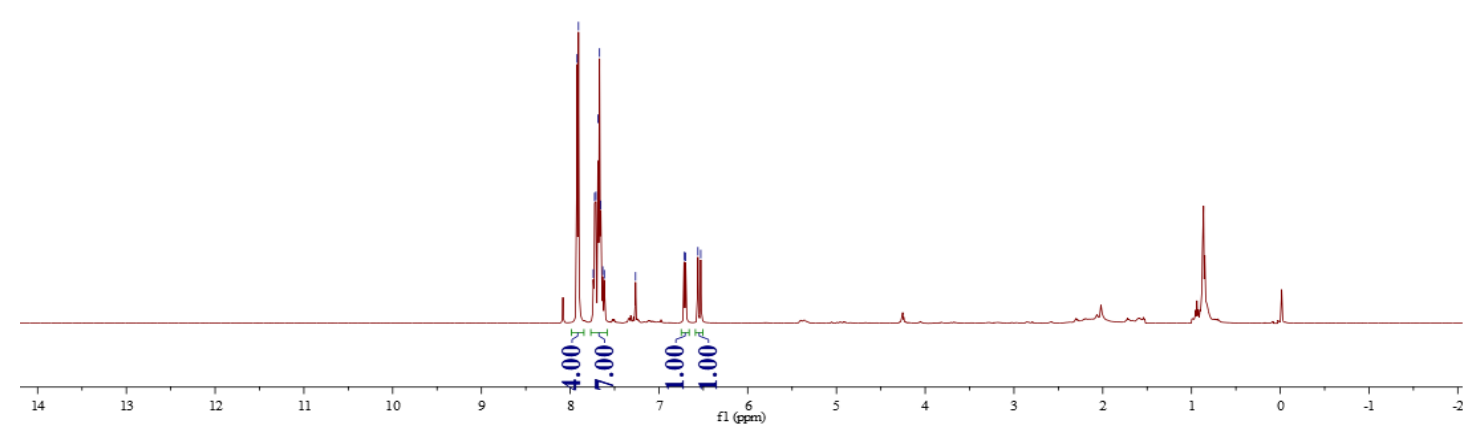

4) In the reaction of (2-iodoethyl)diphenylsulfonium triflate (2f) with $\mathrm{KHCO}_{3}, 39.7$ $\mathrm{mg}$ of unknown product was obtained as a brown-green oil. ${ }^{1} \mathrm{H} \mathrm{NMR}(500 \mathrm{MHz}$, $\left.\mathrm{CDCl}_{3}\right) \delta 7.92(\mathrm{~d}, J=7.9 \mathrm{~Hz}, 4 \mathrm{H}), 7.72-7.63(\mathrm{~m}, 7 \mathrm{H}), 6.69(\mathrm{dd}, J=8.8 \mathrm{~Hz}, 1.6 \mathrm{~Hz}$, $1 \mathrm{H}), 6.56(\mathrm{~d}, J=15.9 \mathrm{~Hz}, 1 \mathrm{H}) .{ }^{13} \mathrm{C} \mathrm{NMR}\left(126 \mathrm{MHz}, \mathrm{CDCl}_{3}\right) \delta 137.2,133.6,130.6$, 130.0, 129.8, 128.2, 126.1, 124.1, 122.4, 119.8 (q, $J=320.8 \mathrm{~Hz})$.

Figure S4. NMR spectra of the above product.

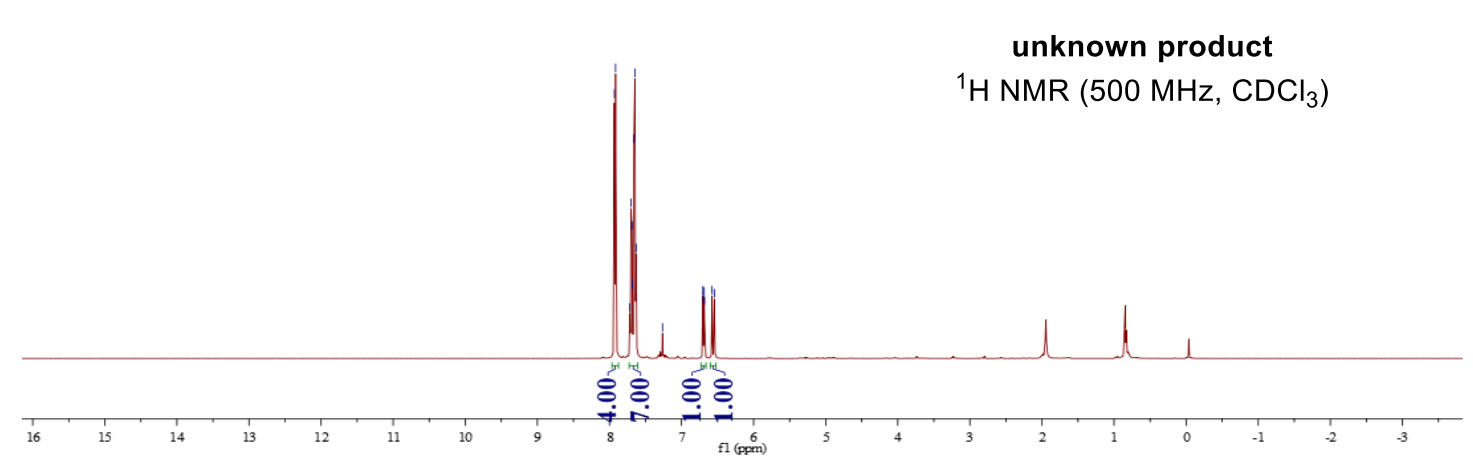




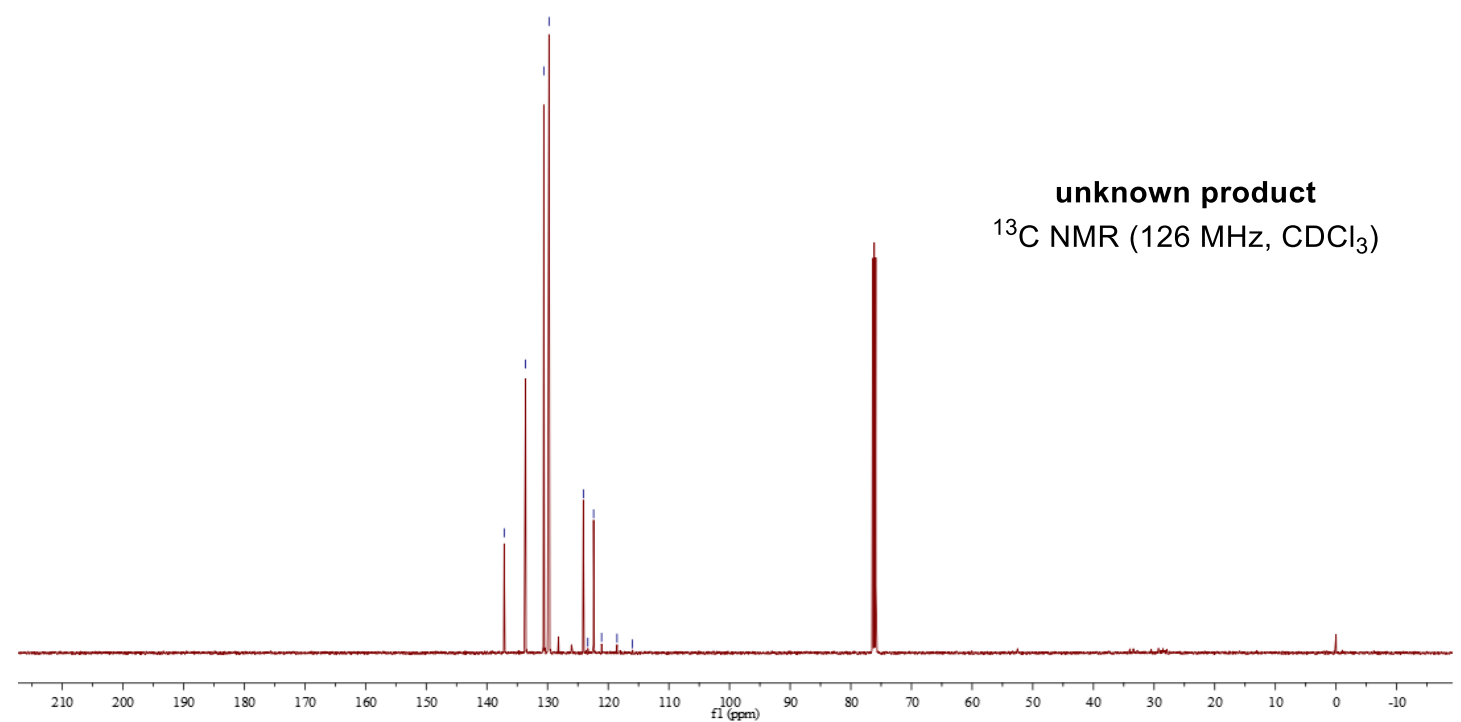

5) In the reaction of diphenyl(2-(tosyloxy)ethyl)sulfonium triflate (2h) with $\mathrm{KHCO}_{3}$, $56.8 \mathrm{mg}$ of $\mathbf{2 b}$ was obtained as a light yellow oil (78\%).

Figure S5. ${ }^{1} \mathrm{H}$ NMR spectrum of the above product.

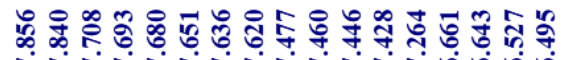

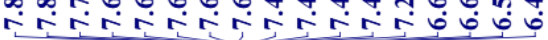

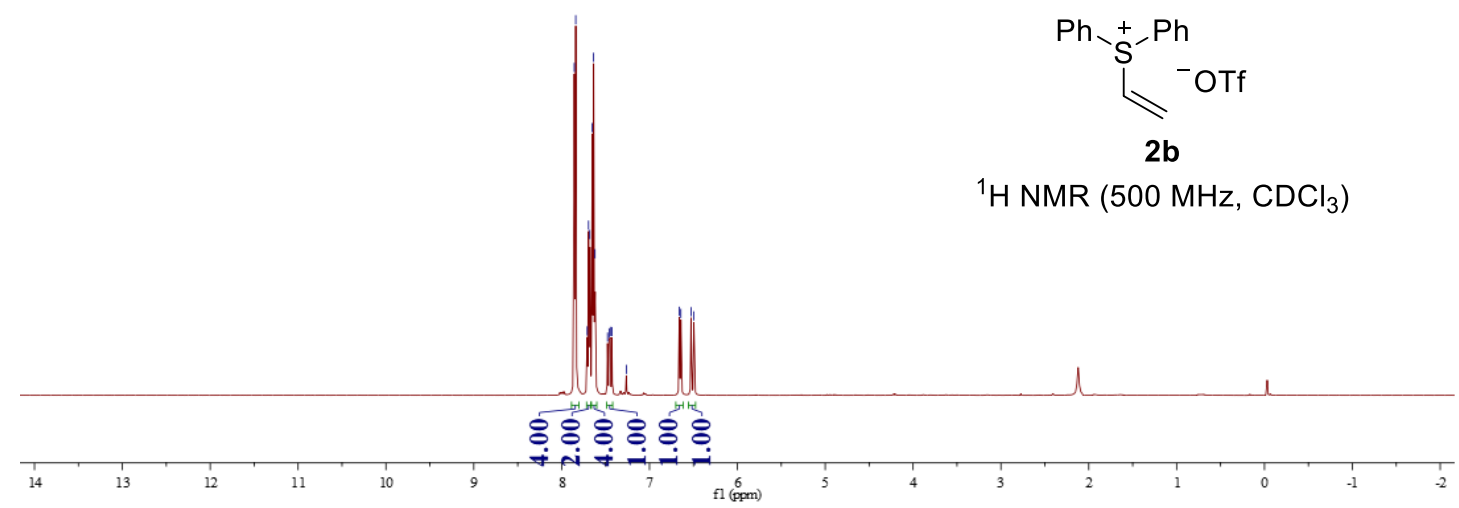


6) Synthesis of 5-vinyl-5H-thianthren-5-ium triflate (2k) from 5-(2-bromoethyl)-5Hthianthren-5-ium triflate (2i)
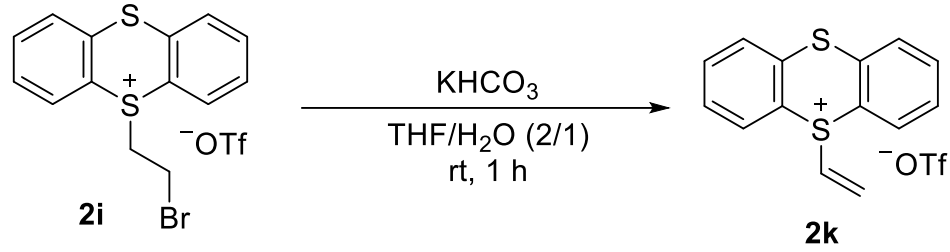

Procedure: To a solution of 5-(2-bromoethyl)-5H-thianthren-5-ium triflate (2i, $1.18 \mathrm{~g}, 2.5 \mathrm{mmol})$ in $\mathrm{THF} / \mathrm{H}_{2} \mathrm{O}(2 / 1(\mathrm{v} / \mathrm{v}), 15 \mathrm{~mL})$ was added $\mathrm{KHCO}_{3}(0.75 \mathrm{~g}, 7.5$ mmol) with stirring. The mixture was reacted at $25{ }^{\circ} \mathrm{C}$ for $1 \mathrm{~h}$, dried over anhydrous $\mathrm{Na}_{2} \mathrm{SO}_{4}$, and concentrated to dryness under reduced pressure. The residue was purified by column chromatography on silica gel using a mixture of $\mathrm{DCM} / \mathrm{MeCN}=3 / 1(\mathrm{v} / \mathrm{v})$ as eluents to give 5-vinyl-5H-thianthren-5-ium triflate (2k) as a white solid (169 mg, 17\%). M.p.: 106.0-108.0 ${ }^{\circ} \mathrm{C} .{ }^{1} \mathrm{H}$ NMR (500 $\left.\mathrm{MHz}, \mathrm{CDCl}_{3}\right) \delta 8.44(\mathrm{dm}, J=7.9 \mathrm{~Hz}, 2 \mathrm{H}), 7.84(\mathrm{dm}, J=7.9 \mathrm{~Hz}, 2 \mathrm{H}), 7.77(\mathrm{tm}, J$ $=7.7 \mathrm{~Hz}, 2 \mathrm{H}), 7.70(\mathrm{tm}, J=7.7 \mathrm{~Hz}, 2 \mathrm{H}), 6.77(\mathrm{dd}, J=16.1,8.9 \mathrm{~Hz}, 1 \mathrm{H}), 6.29(\mathrm{dd}$, $J=8.9,2.9 \mathrm{~Hz}, 1 \mathrm{H}), 6.25(\mathrm{dd}, J=15.9,2.9 \mathrm{~Hz}, 1 \mathrm{H}) .{ }^{19} \mathrm{~F} \mathrm{NMR}\left(471 \mathrm{MHz}, \mathrm{CDCl}_{3}\right)$ $\delta$-78.2 (s, 3F). ${ }^{13} \mathrm{C}$ NMR (126 MHz, $\left.\mathrm{CDCl}_{3}\right) \delta 136.1,134.7,134.7,134.1,130.3$, $130.1,120.8(\mathrm{q}, J=320.3 \mathrm{~Hz}), 119.7,118.5$.

Figure S6. NMR spectra of 2k. 


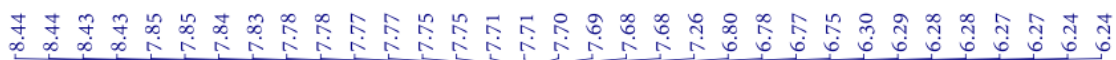
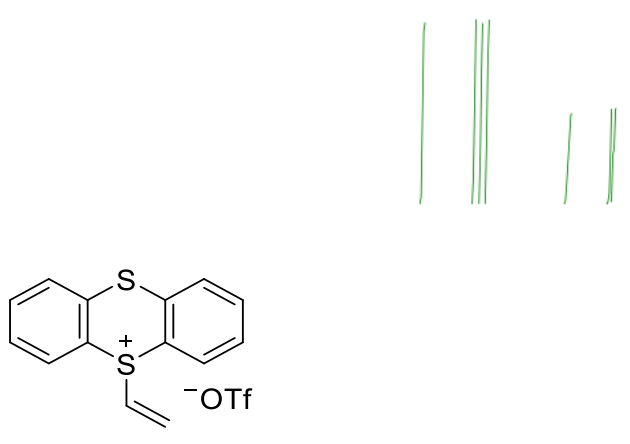

2k

${ }^{1} \mathrm{H}$ NMR $\left(500 \mathrm{MHz}, \mathrm{CDCl}_{3}\right)$

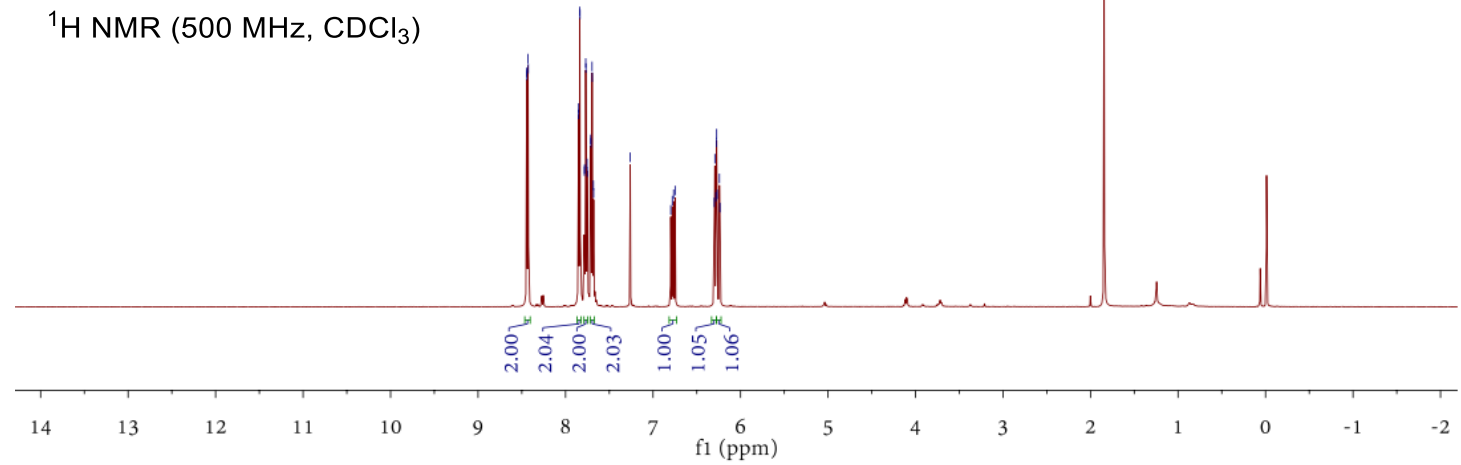

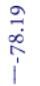

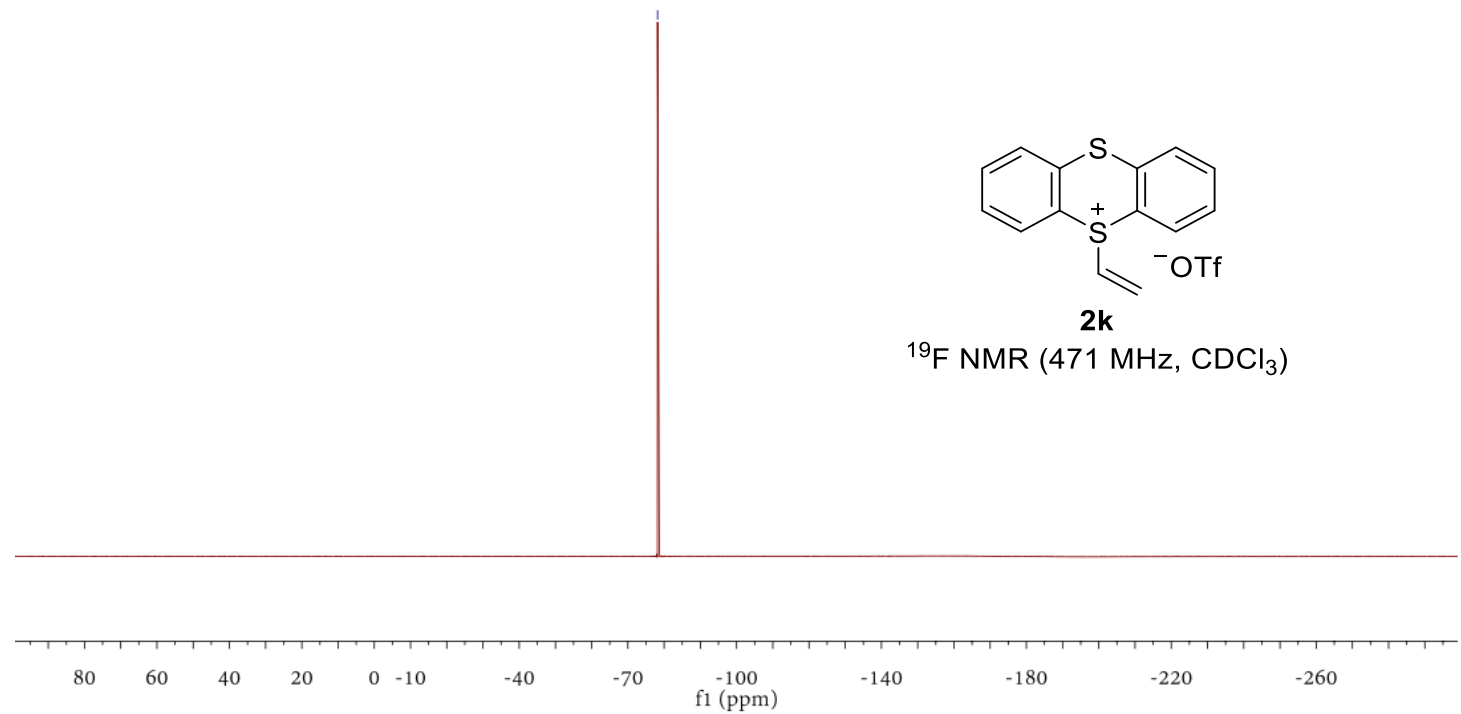




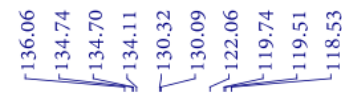

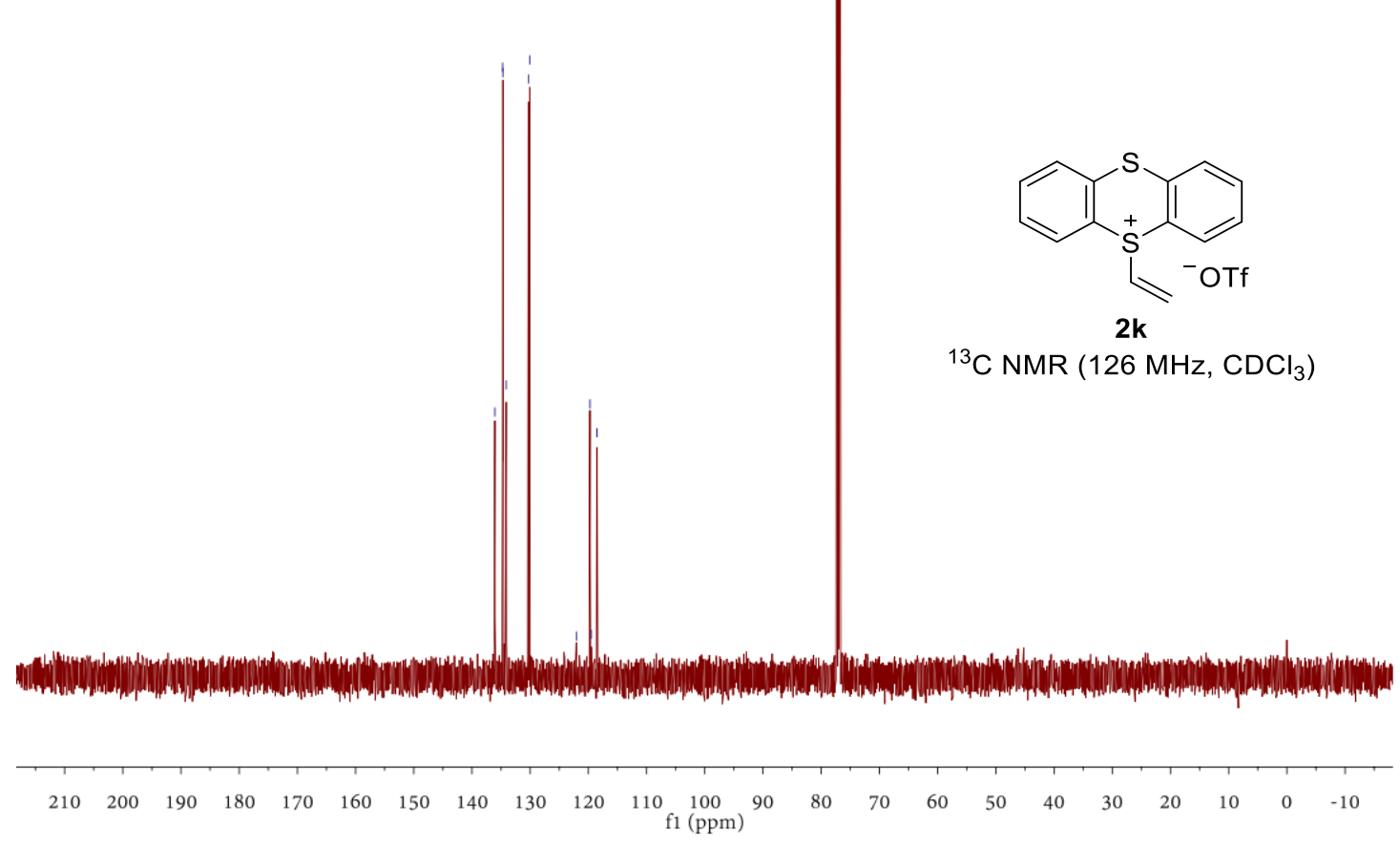

7) Synthesis of 1-vinyltetrahydro-1H-thiophen-1-ium triflate (21) from 1-(2-bromoethyl)tetrahydro-1H-thiophen-1-ium triflate $(\mathbf{2} \mathbf{j})$

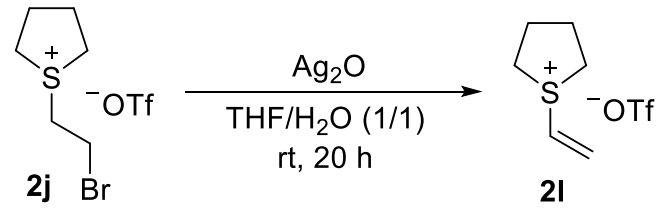

Procedure: To a solution of 1-(2-bromoethyl)tetrahydro-1H-thiophen-1-ium triflate $(2 \mathbf{j}, 0.344 \mathrm{~g}, 2.5 \mathrm{mmol})$ in $\mathrm{THF} / \mathrm{H}_{2} \mathrm{O}(1 / 1(\mathrm{v} / \mathrm{v}), 2 \mathrm{~mL})$ was added silver oxide $\left(\mathrm{Ag}_{2} \mathrm{O}, 0.580 \mathrm{~g}, 2.5 \mathrm{mmol}\right)$ with stirring. The mixture was reacted at $25{ }^{\circ} \mathrm{C}$ for $20 \mathrm{~h}$, filtered through a celite pad, and washed with DCM $(2 \times 5 \mathrm{~mL})$. The filtrates were dried over anhydrous $\mathrm{Na}_{2} \mathrm{SO}_{4}$ and concentrated to dryness under reduced pressure. The residue underwent column chromatography on silica gel using a mixture of $\mathrm{DCM} / \mathrm{MeCN}=3 / 1(\mathrm{v} / \mathrm{v})$ as eluents to give impure 1-vinyl tetrahydro-1H-thiophen-1-ium triflate (2l) as a colorless oil $(98.7 \mathrm{mg}) .{ }^{1} \mathrm{H}$ NMR $\left(500 \mathrm{MHz}, \mathrm{CDCl}_{3}\right) \delta 6.72(\mathrm{~m}, 1 \mathrm{H}), 6.45-6.28(\mathrm{~m}, 2 \mathrm{H}), 3.92(\mathrm{~m}, 1 \mathrm{H}), 3.76(\mathrm{~m}, 1 \mathrm{H})$, 3.57-3.49 (m, 2H), 2.50-2.31 (m, 4H). $\left.{ }^{19} \mathrm{~F} \mathrm{NMR} \mathrm{(471} \mathrm{MHz,} \mathrm{CDCl}_{3}\right) \delta-78.4(\mathrm{~s}$, $3 \mathrm{~F})$. 
Figure S7. NMR spectra of 21.

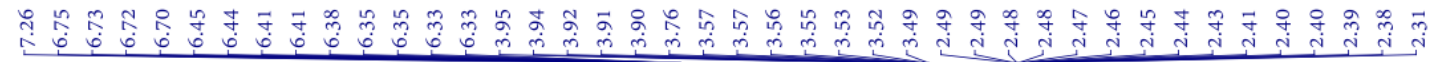
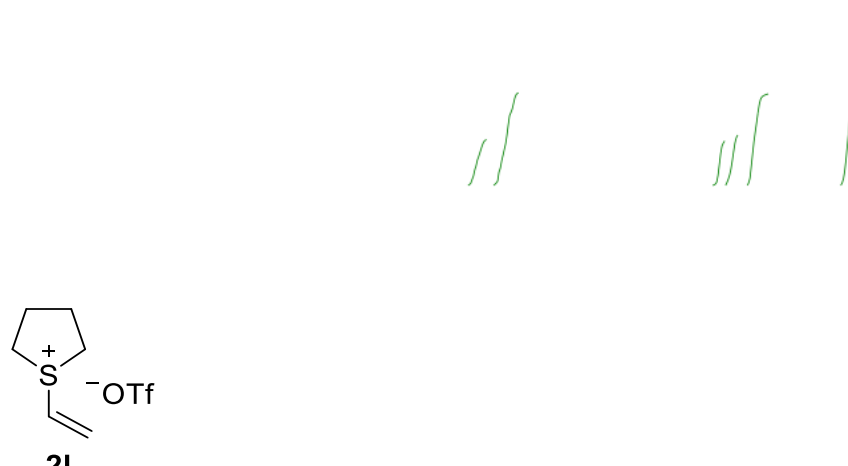

21

${ }^{1} \mathrm{H}$ NMR $\left(500 \mathrm{MHz}, \mathrm{CDCl}_{3}\right)$
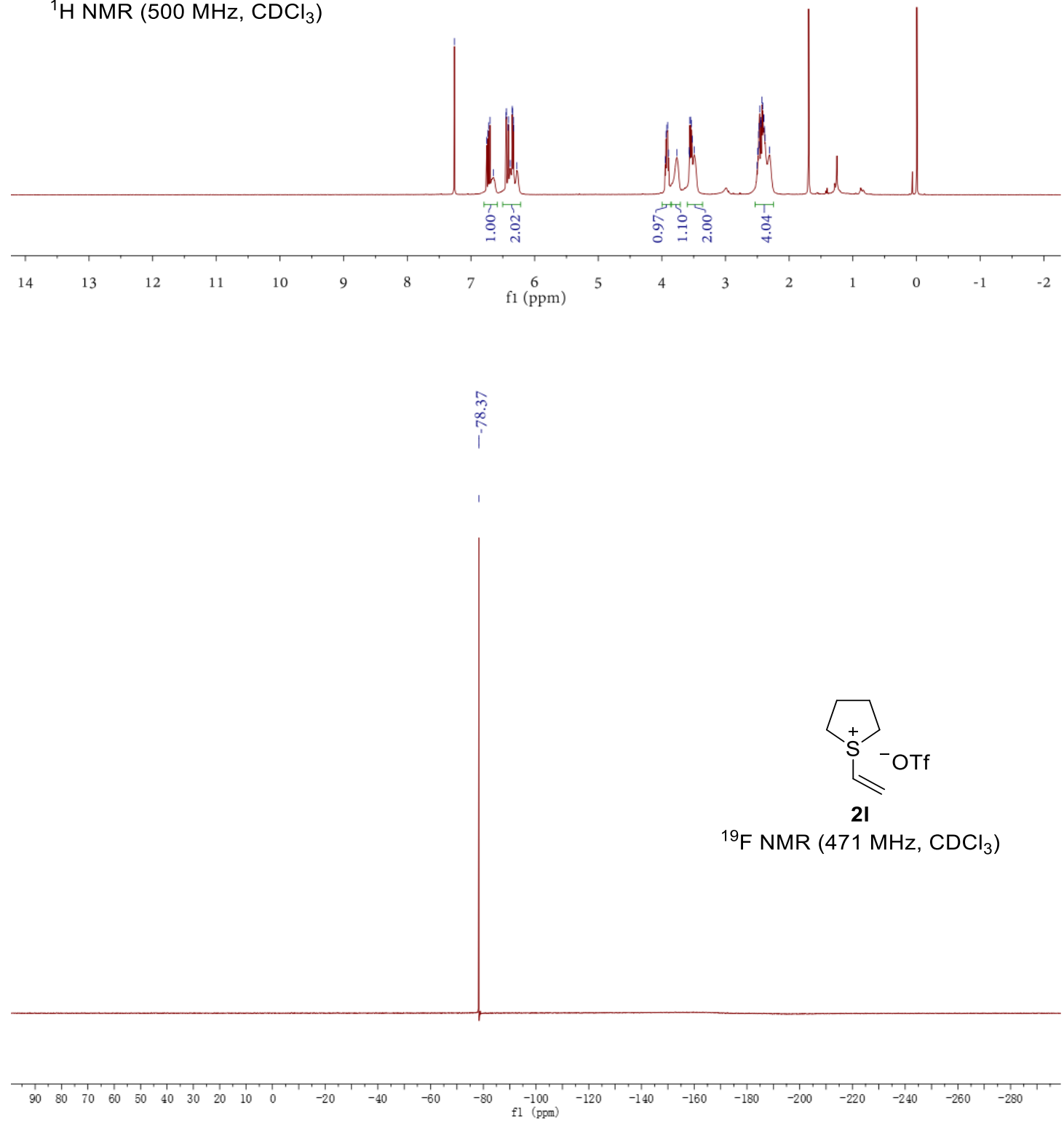
10. ${ }^{1} \mathrm{H}$ NMR analysis of the reaction mixtures of (2-haloethyl)sulfonium triflates or (2-(tosyloxy)ethyl)sulfonium triflate with $\mathrm{K}_{3} \mathrm{PO}_{4}$ in THF- $d 8$.

Procedure: In a nitrogen filled glovebox, $\mathrm{K}_{3} \mathrm{PO}_{4}(0.05 \mathrm{mmol}, 10.6 \mathrm{mg})$ and a solution of $2(0.05 \mathrm{mmol})$ in THF- $d_{8}(0.5 \mathrm{~mL})$ were added to a sealed NMR tube. The NMR tube was shaken at room temperature for $20 \mathrm{~min}$ and analyzed by ${ }^{1} \mathrm{H}$ NMR spectroscopy.

Figure S8. ${ }^{1} \mathrm{H}$ NMR spectrum of the reaction mixture of $\mathrm{K}_{3} \mathrm{PO}_{4}$ and $\mathbf{2 a}$.

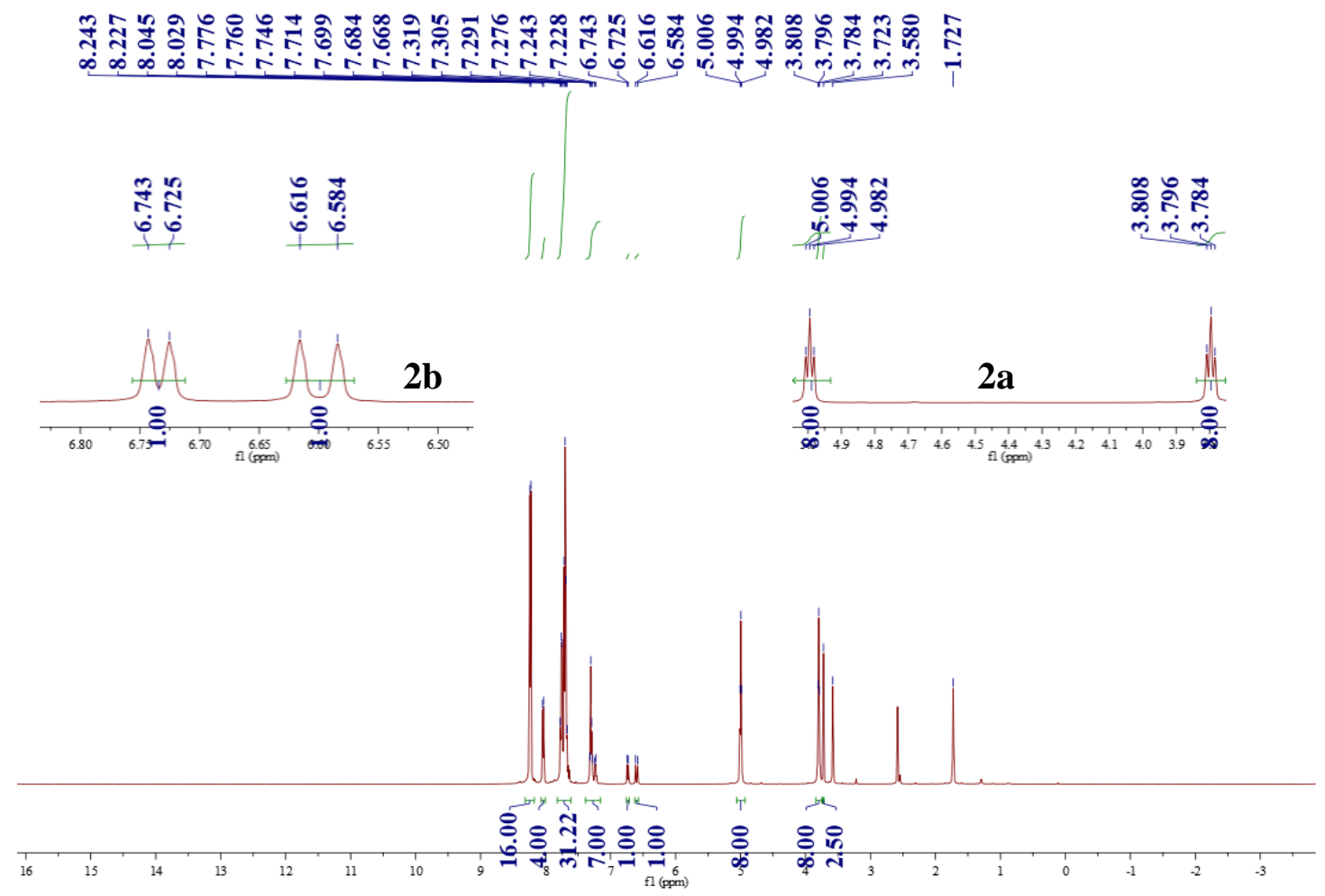

According to the ${ }^{1} \mathrm{H}$ NMR data, minor unknown byproduct was observed. The molar ratio of diphenyl(vinyl)sulfonium triflate (2b) and (2-bromoethyl)diphenyl sulfonium triflate (2a) was $1: 4$.

Figure S9. ${ }^{1} \mathrm{H}$ NMR spectrum of the reaction mixture of $\mathrm{K}_{3} \mathrm{PO}_{4}$ and $2 \mathrm{c}$. 


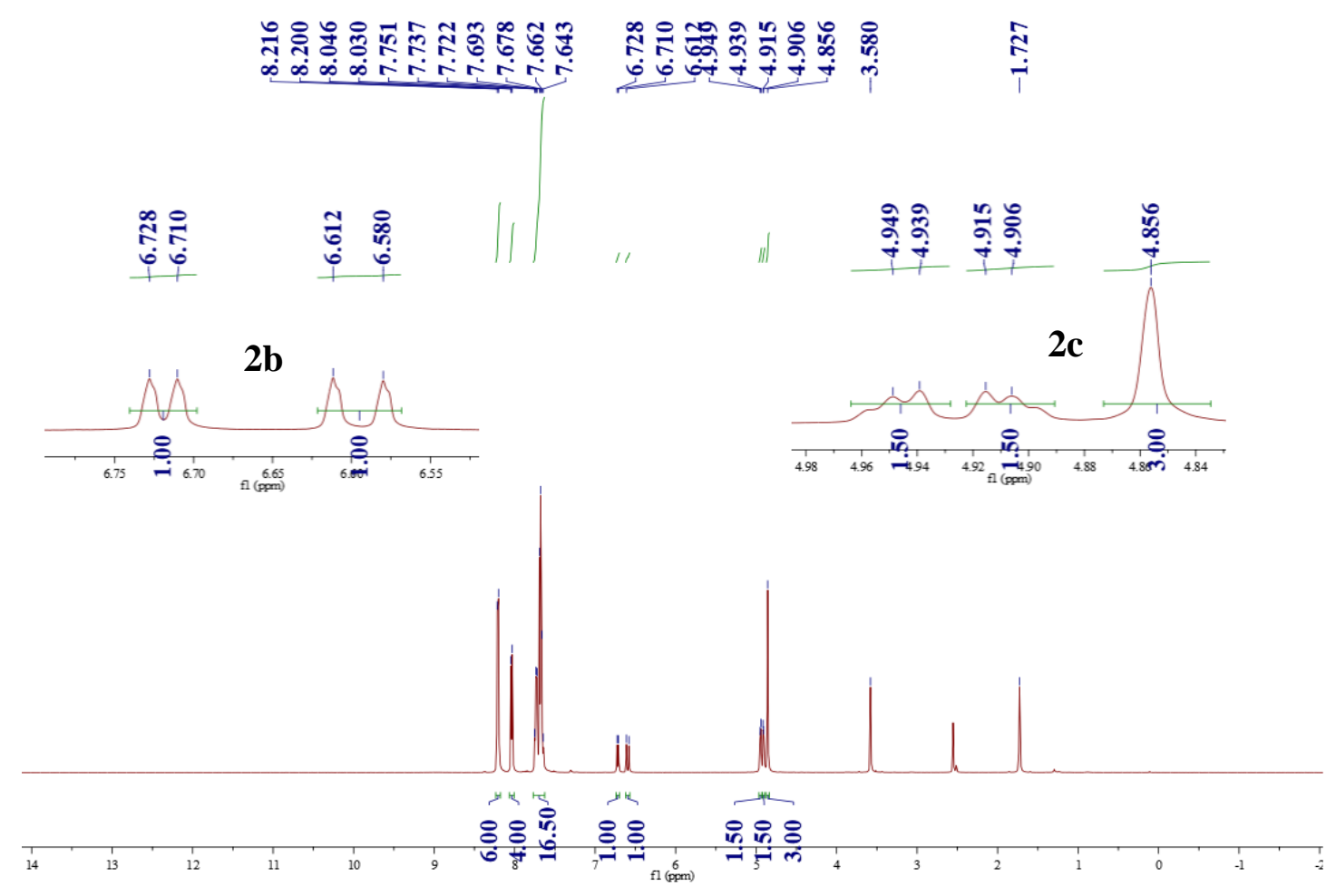

According to the ${ }^{1} \mathrm{H}$ NMR data, the molar ratio of diphenyl(vinyl)sulfonium triflate (2b) and (2-fluoroethyl)diphenylsulfonium triflate (2c) was $1: 1.5$.

Figure S10. ${ }^{1} \mathrm{H}$ NMR spectrum of the reaction mixture of $\mathrm{K}_{3} \mathrm{PO}_{4}$ and $\mathbf{2 d}$.

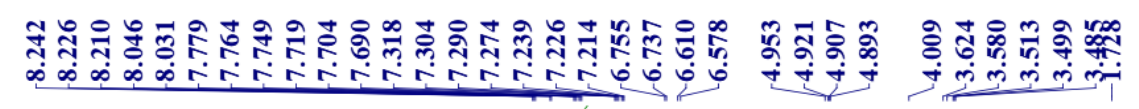
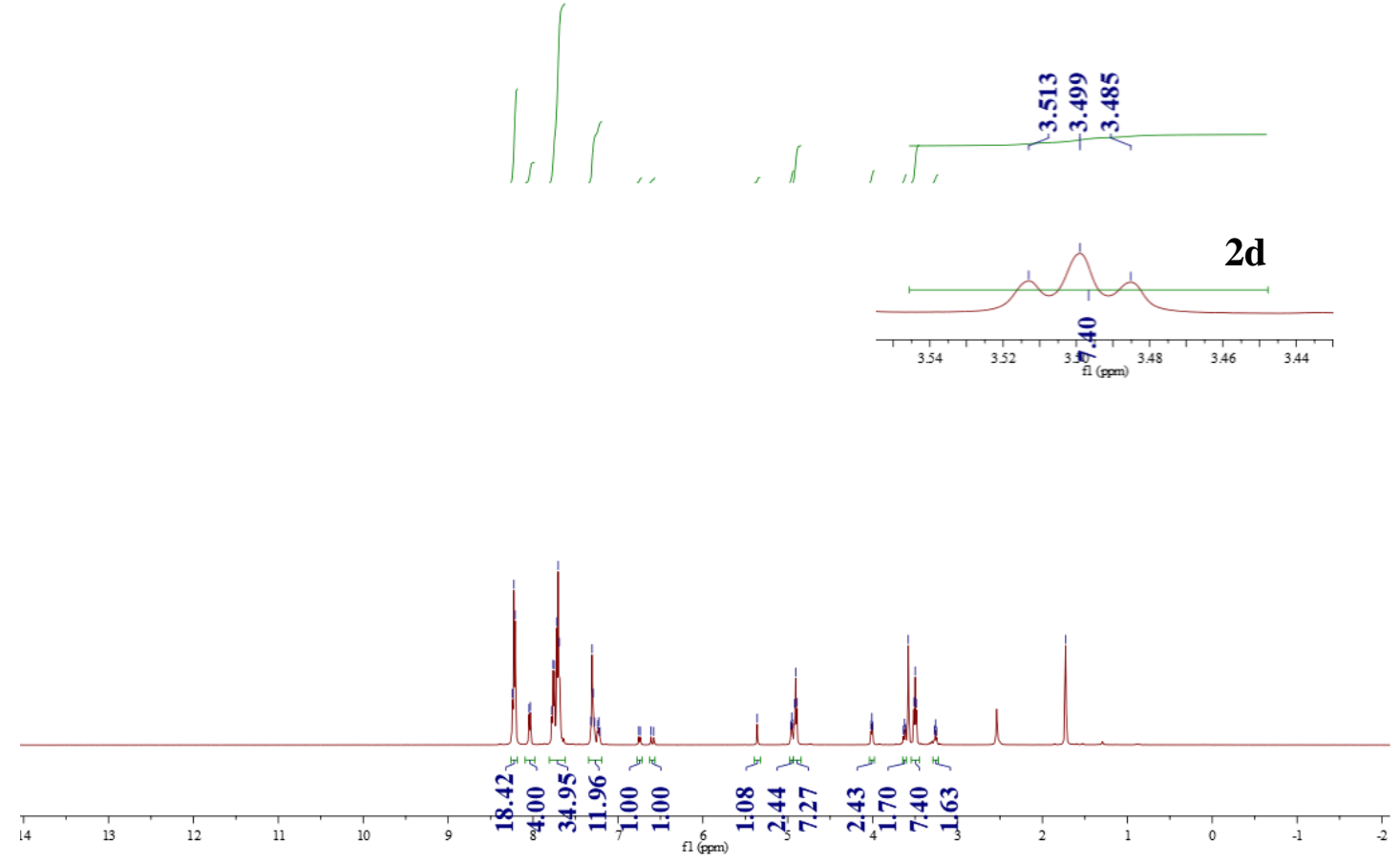

According to the ${ }^{1} \mathrm{H}$ NMR data, a very complicated mixture was obtained. 
Figure S11. ${ }^{1} \mathrm{H}$ NMR spectrum of the reaction mixture of $\mathrm{K}_{3} \mathrm{PO}_{4}$ and $\mathbf{2 f}$.

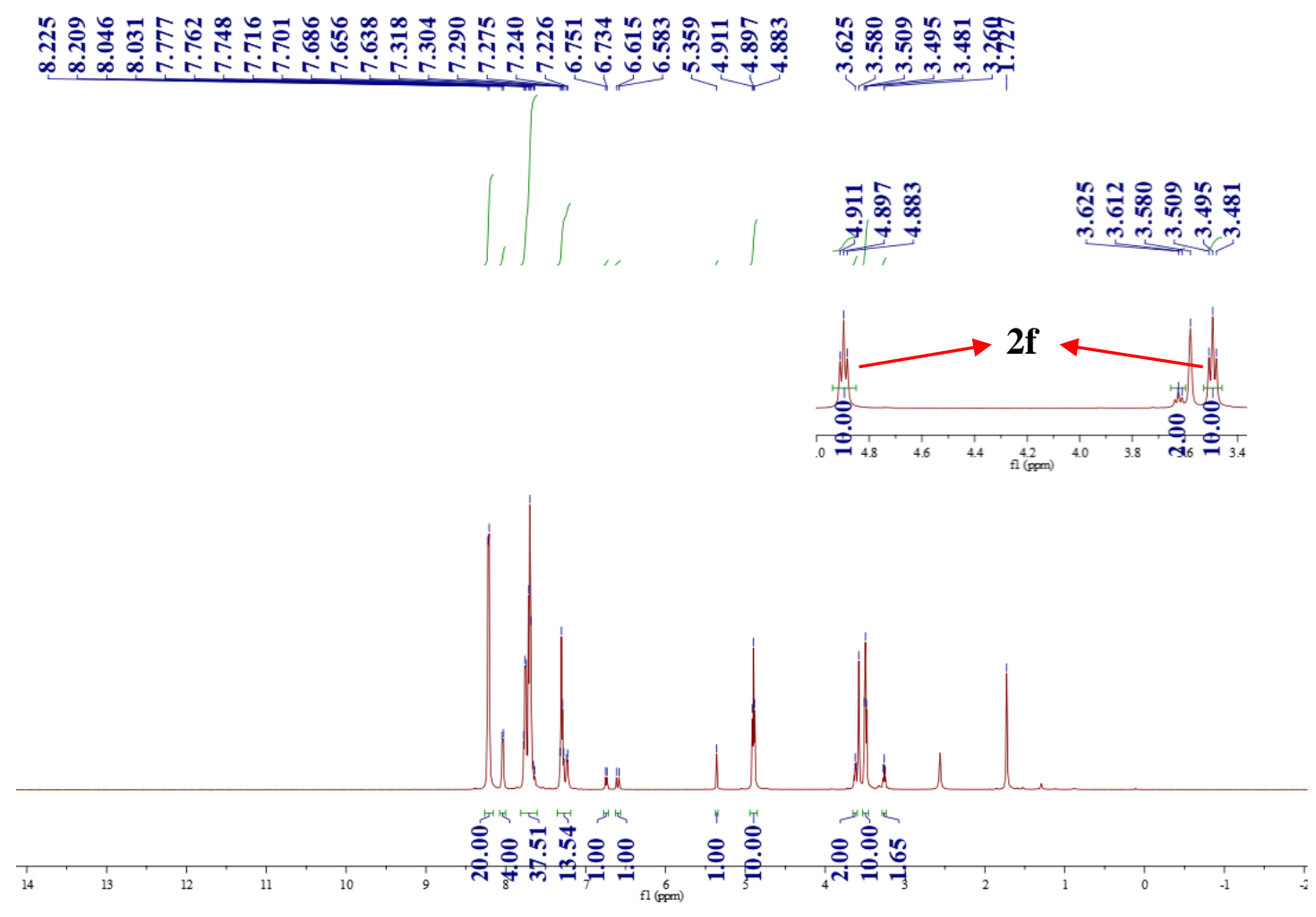

According to the ${ }^{1} \mathrm{H}$ NMR data, a series of unknown byproducts were observed.

Figure S12. ${ }^{1} \mathrm{H}$ NMR spectrum of the reaction mixture of $\mathrm{K}_{3} \mathrm{PO}_{4}$ and $\mathbf{2 h}$.
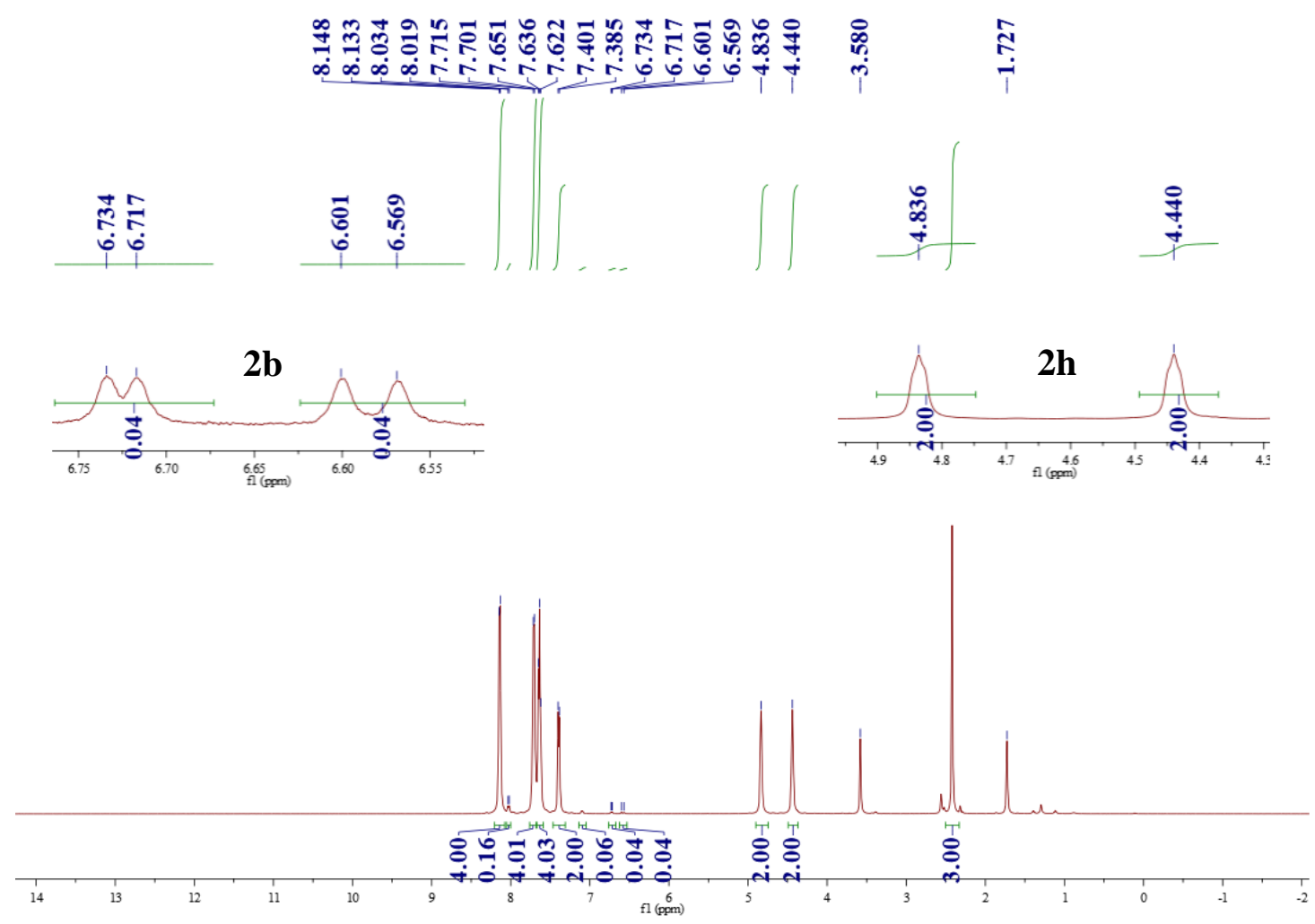
According to the ${ }^{1} \mathrm{H}$ NMR data, the molar ratio of diphenyl(vinyl)sulfonium triflate (2b) and diphenyl(2-(tosyloxy)ethyl) sulfonium triflate (2h) was $1: 25$.

Figure S13. ${ }^{1} \mathrm{H}$ NMR spectrum of the reaction mixture of $\mathrm{K}_{3} \mathrm{PO}_{4}$ and $2 \mathbf{i}$.

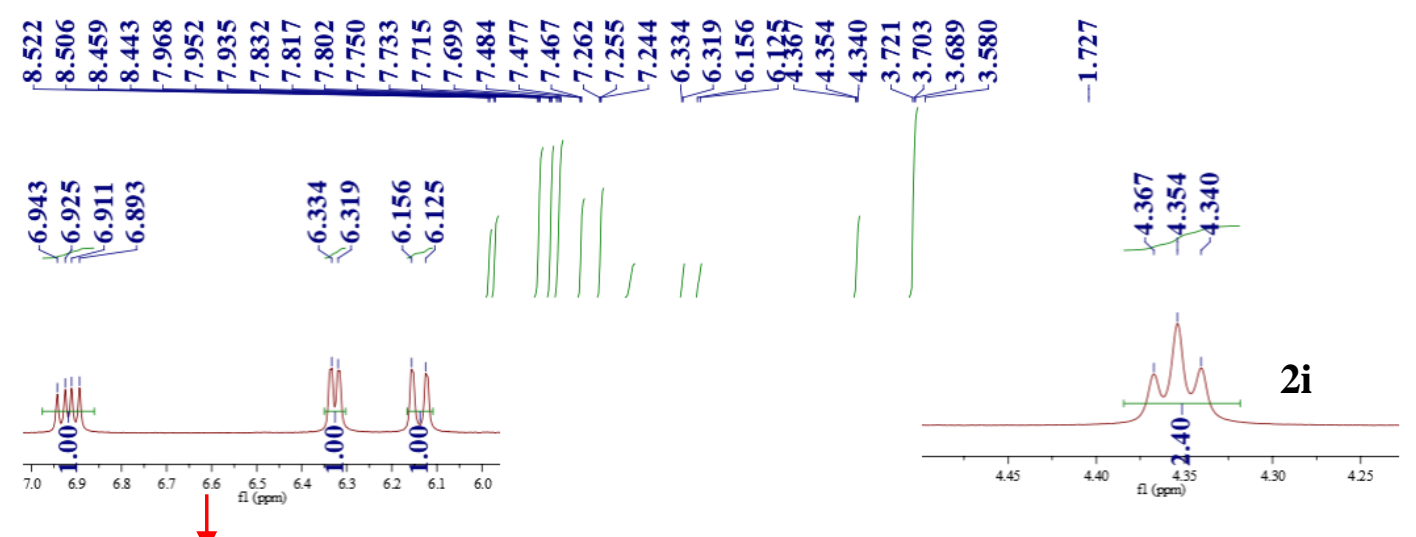

5-vinyl-5H-thianthren-5-ium triflate

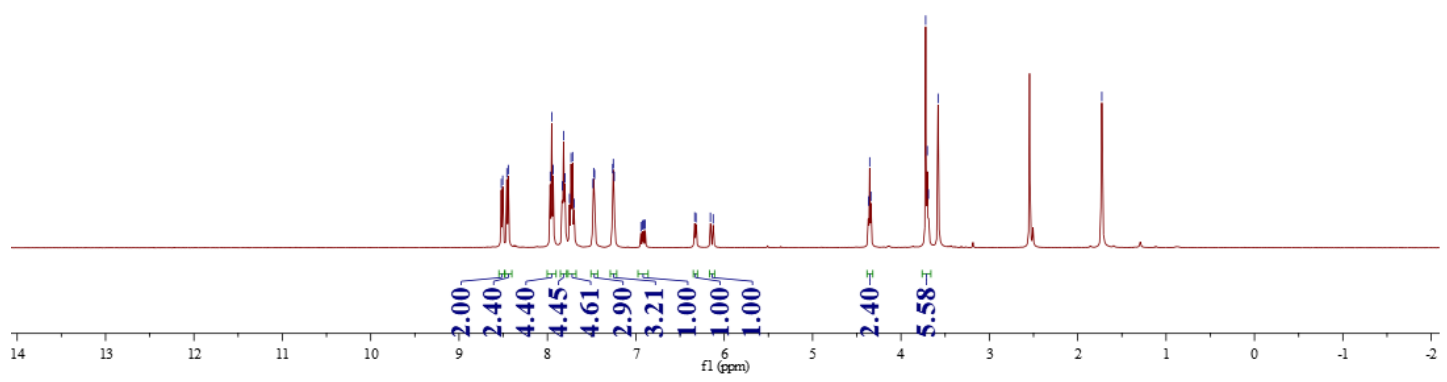

According to the ${ }^{1} \mathrm{H}$ NMR data, minor unknown byproduct was observed. The molar ratio of 5-vinyl-5H-thianthren-5-ium triflate and 5-(2-bromoethyl)-5H-thianthren5-ium triflate (2i) in THF- $d_{8}$ was about $1: 1.2$ (Note: both 5-vinyl-5H-thianthren5-ium triflate and 5-(2-bromoethyl)-5H-thianthren-5-ium triflate were poorly soluble in THF- $\left.d_{8}\right)$.

Figure S14. ${ }^{1} \mathrm{H}$ NMR spectrum of the reaction mixture of $\mathrm{K}_{3} \mathrm{PO}_{4}$ and $\mathbf{2 j}$. 


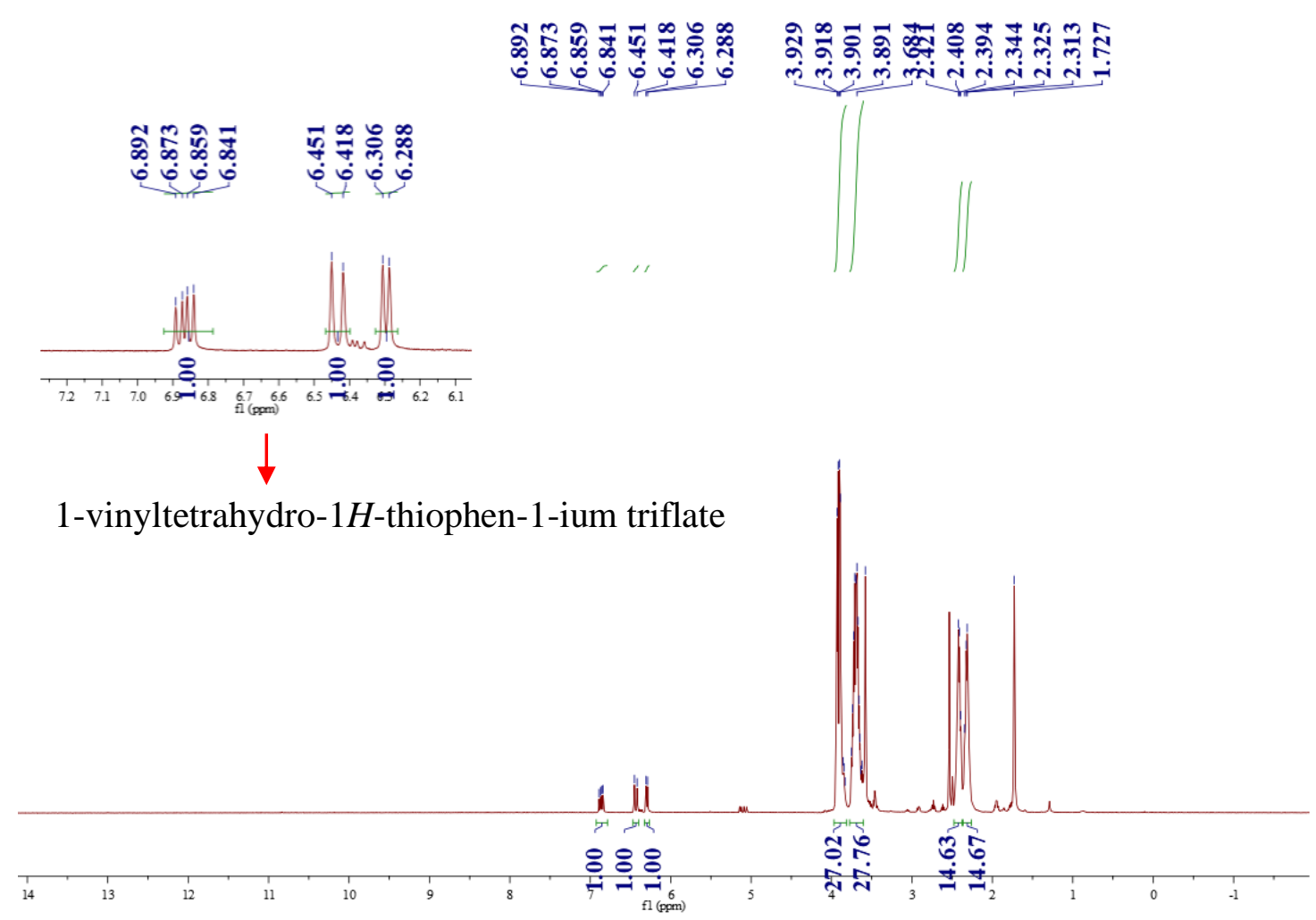

According to the ${ }^{1} \mathrm{H}$ NMR data, minor unknown byproduct was observed. The molar ratio of 1-vinyltetrahydro-1 $H$-thiophen-1-ium triflate and 1-(2-bromoethyl)tetrahydro$1 H$-thiophen-1-ium triflate $(\mathbf{2} \mathbf{j})$ was approximately $1: 6$.

\section{References:}

[1] X.-Y. Wang, H.-X. Song, S.-M. Wang, J. Yang, H.-L. Qin, X. Jiang, C.-P. Zhang, Tetrahedron 2016, 72, 7606-7612.

[2] W. L. F. Armarego, C. L. L. Chai, Purification of Laboratory Chemicals, $5^{\text {th }}$ ed.; Butterworth Heinemann: Oxford, 2003.

[3] M. Yar, E. M. McGarrigle, V. K. Aggarwal, Angew. Chem. Int. Ed. 2008, 47, 3784 $-3786$.

[4] Y.-F. Wang, W.-H. Zhang, V. J. Colandrea, L. S. Jimenez, Tetrahedron 1999, 55, 10659-1067.

[5] M. Popr, S. Hybelbauerová, J. Jindřich, Beilstein J. Org. Chem. 2014, 10, 1390-1396.

[6] H. Dang, M. Mailig, G. Lalic, Angew. Chem. Int. Ed. 2014, 53, 6473-6476.

[7] L.-B. Su, T.-B. Ren, J.-Y. Dong, L.-X. Liu, S.-M. Xie, L. Yuan, Y.-B. Zhou, S.-F. Yin, J. Am. Chem. Soc. 2019, 141, 2535-2544. 
[8] Z.-Y. Tian, S.-M. Wang, S.-J. Jia, H.-X. Song, C.-P. Zhang, Org. Lett. 2017, 19, 5454-5457.

[9] K. Norseeda, N. Chaisan, C. Thongsornkleeb, J. Tummatorn, S. Ruchirawat, J. Org. Chem. 2019, 84, 16222-16236.

[10] R. A. Fernandes, S. P. Gholap, V. P. Chavan, A. S. Saiyed, S. Bhattacharyya, Org. Lett. 2020, 22, 3438-3443.

[11] H. Li, Z.-Q, Xia, S.-J. Chen, K. Koya, M. Ono, L.-J Sun, Org. Process Res. Dev. 2007, 11, 246-250.

[12] H.-J. Li, R. Guillot, V. Gandon, J. Org. Chem. 2010, 75, 8435-8449.

[13] (a) J.-F. Chen, C.-K. Li, ACS Catal. 2020, 10, 3881-3889. (b) Y. Zhang, B. Yu, B. Gao, T. Zhang, H. Huang, Org. Lett. 2019, 21, 535-539.

[14] S.-Q. Yang, Y.-F. Wang, W.-C. Zhao, G.-Q. Lin, Z.-T. He, J. Am. Chem. Soc. 2021, 143, 7285-7291.

[15] Y. Liao, X.-M. Yin, X.-H. Wang, W.-Z. Yu, D.-M. Fang, L.-R. Hu, M. Wang, J. Liao, Angew. Chem. Int. Ed. 2020, 59, 1176-1180. 


\section{NMR spectra of the products}

(2-Bromoethyl)diphenylsulfonium triflate (2a)
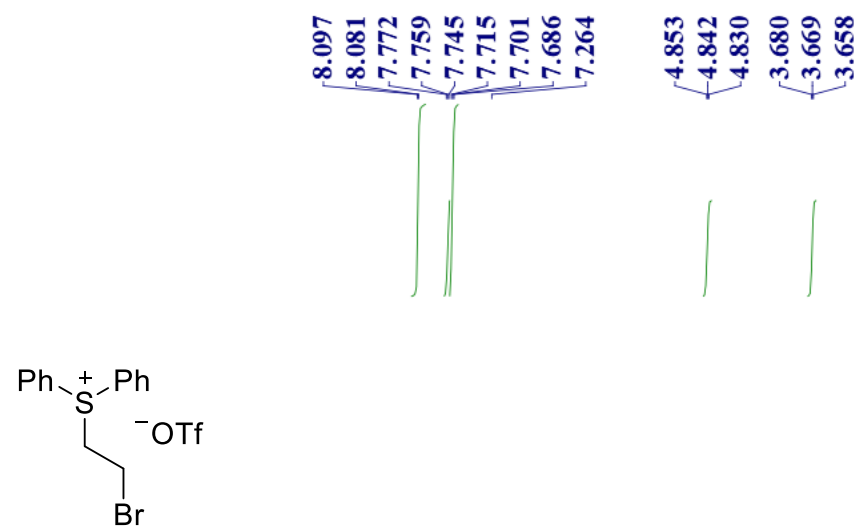

${ }^{1} \mathrm{H} \mathrm{NMR}\left(500 \mathrm{MHz}, \mathrm{CDCl}_{3}\right)$
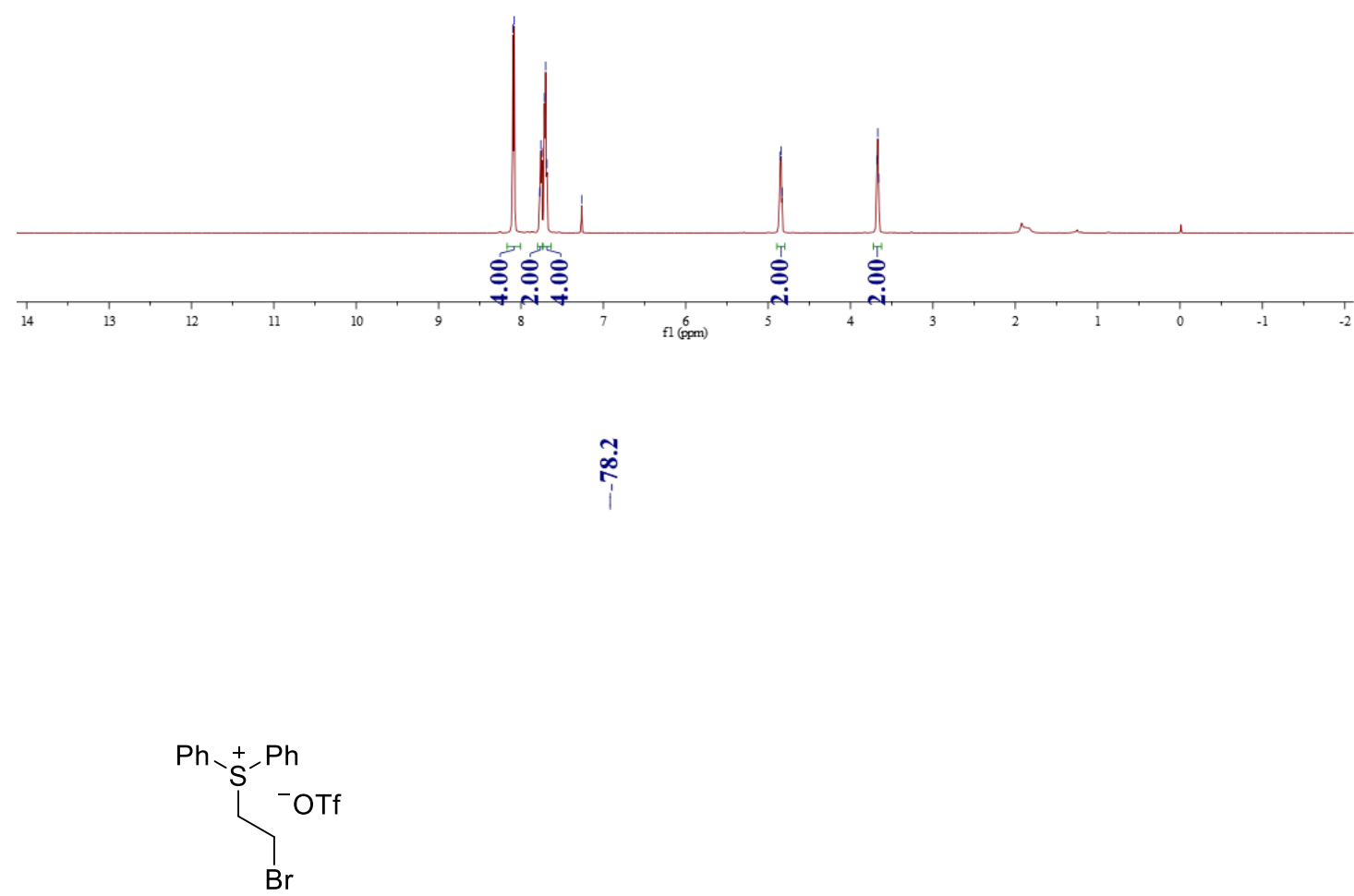

${ }^{19} \mathrm{~F} \mathrm{NMR}\left(471 \mathrm{MHz}, \mathrm{CDCl}_{3}\right)$ 


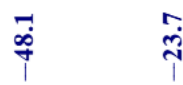

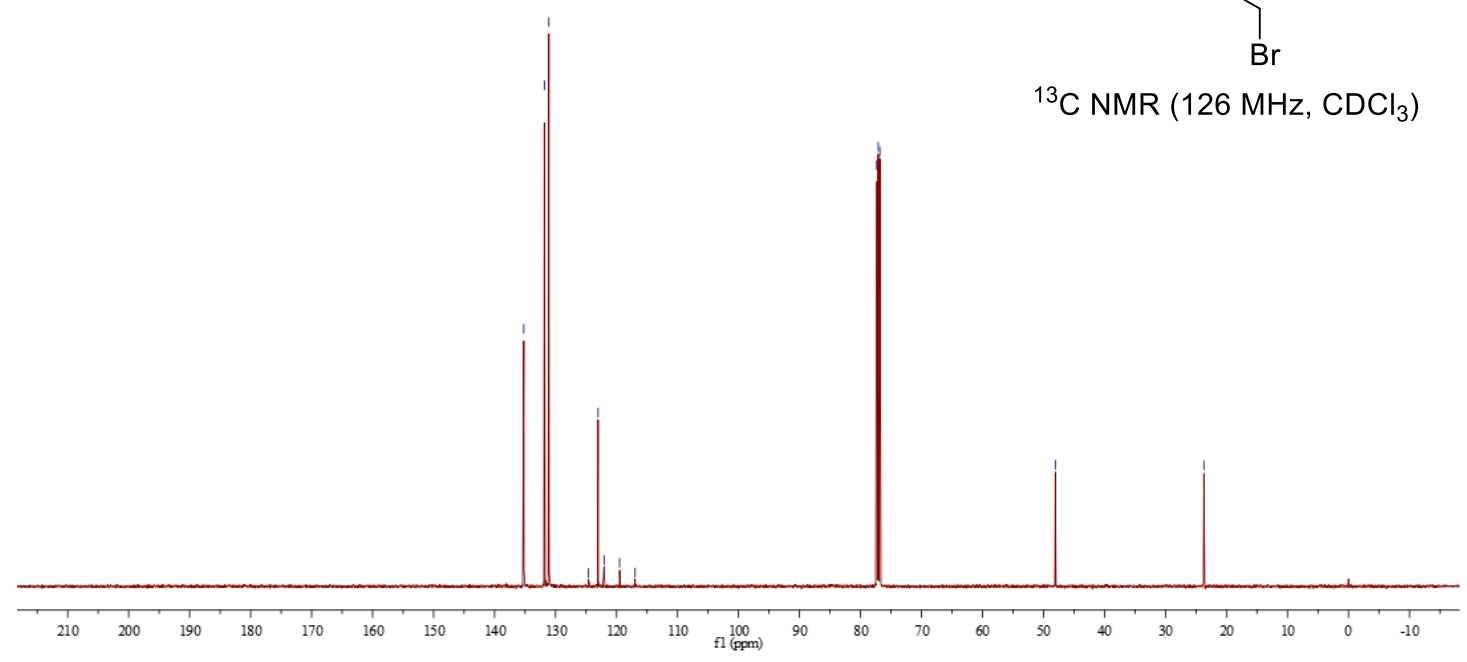

Diphenyl(vinyl)sulfonium triflate (2b)

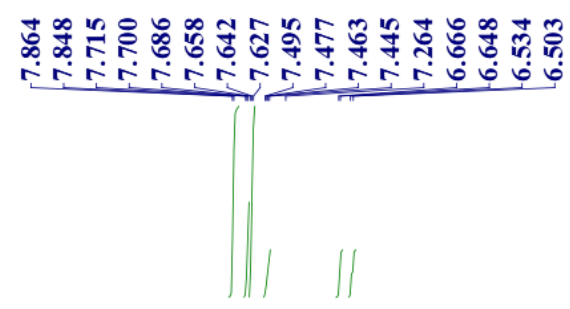

${ }^{\mathrm{Ph}}+\stackrel{+}{\mathrm{S}}-\mathrm{Ph}$

${ }^{1} \mathrm{H} \mathrm{NMR}\left(500 \mathrm{MHz}, \mathrm{CDCl}_{3}\right)$

\section{$80 \% 8$}

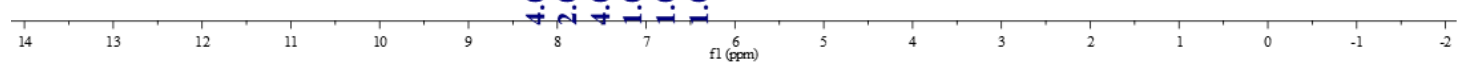




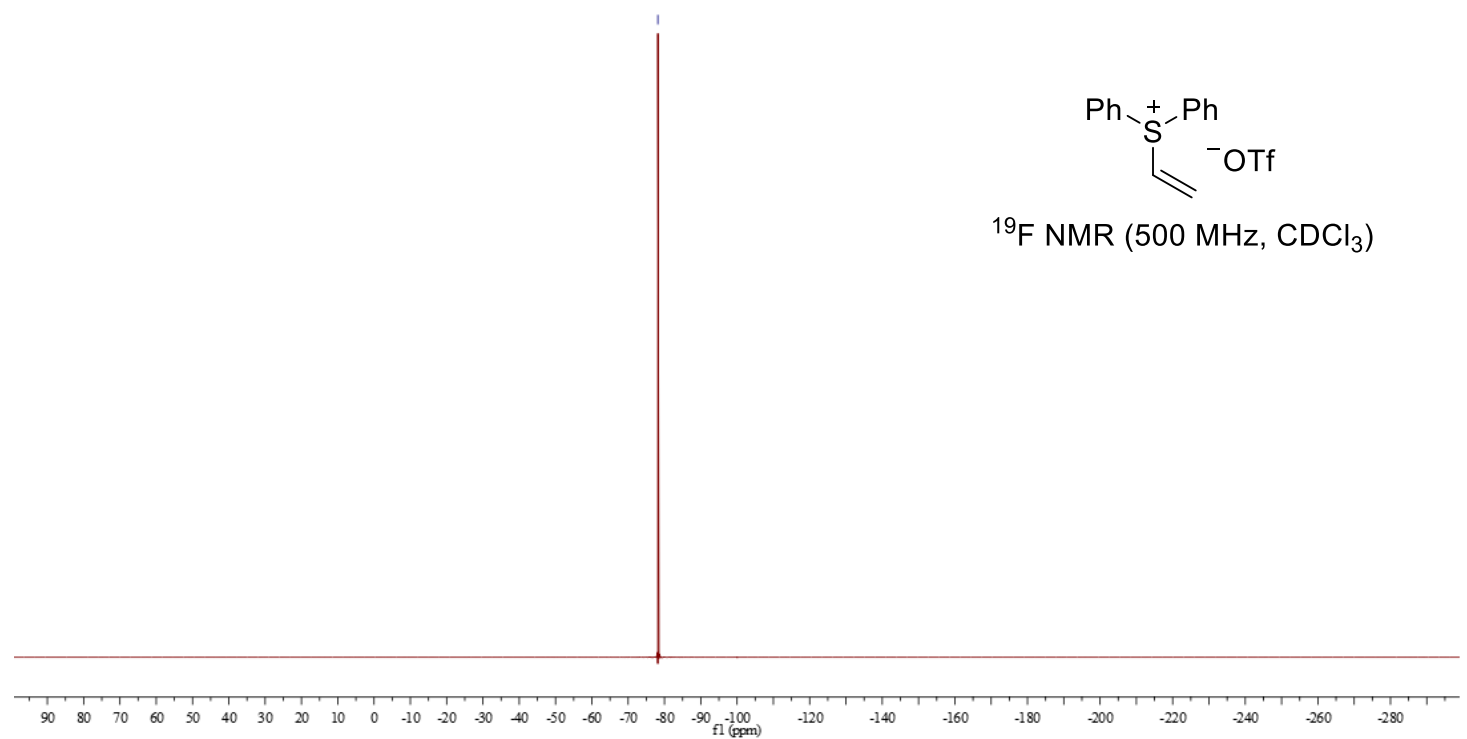

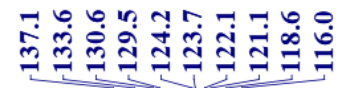

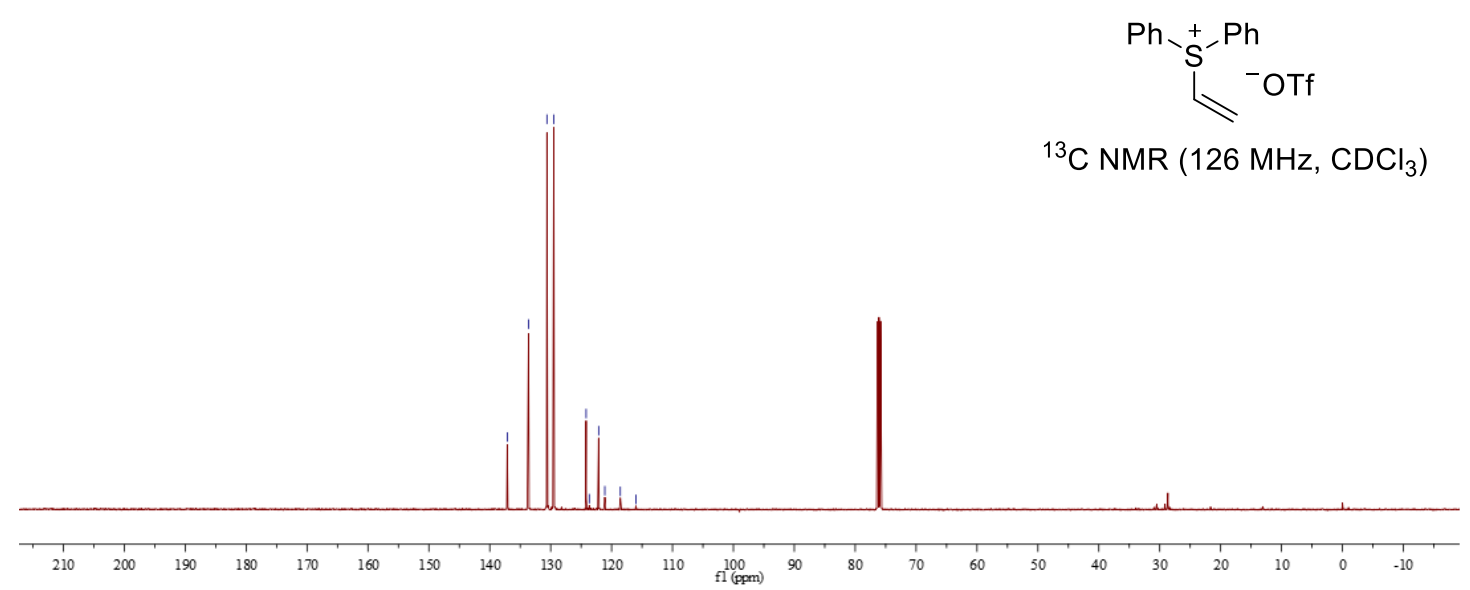


(2-Chloroethyl)diphenylsulfonium triflate (2d)
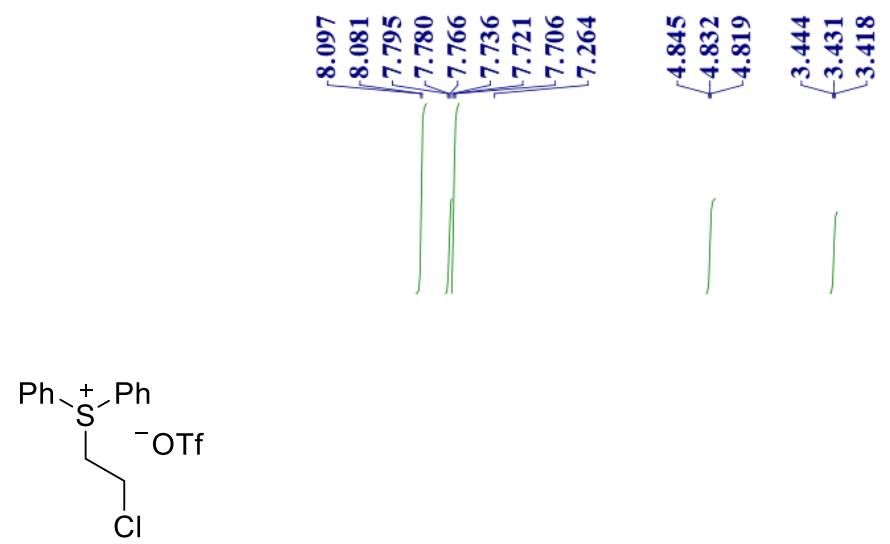

${ }^{1} \mathrm{H}$ NMR $\left(500 \mathrm{MHz}, \mathrm{CDCl}_{3}\right)$
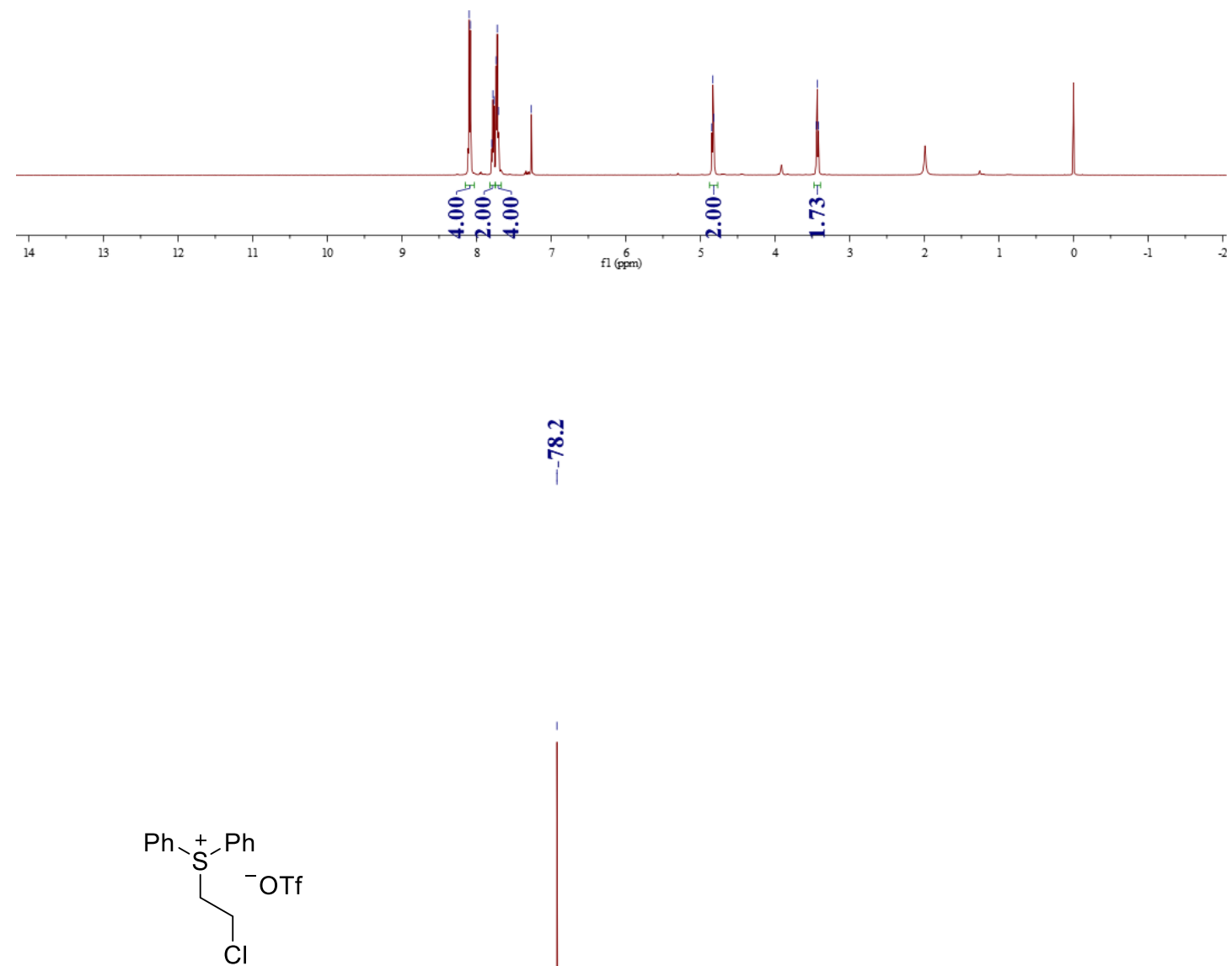

${ }^{19} \mathrm{~F}$ NMR $\left(471 \mathrm{MHz}, \mathrm{CDCl}_{3}\right)$ 

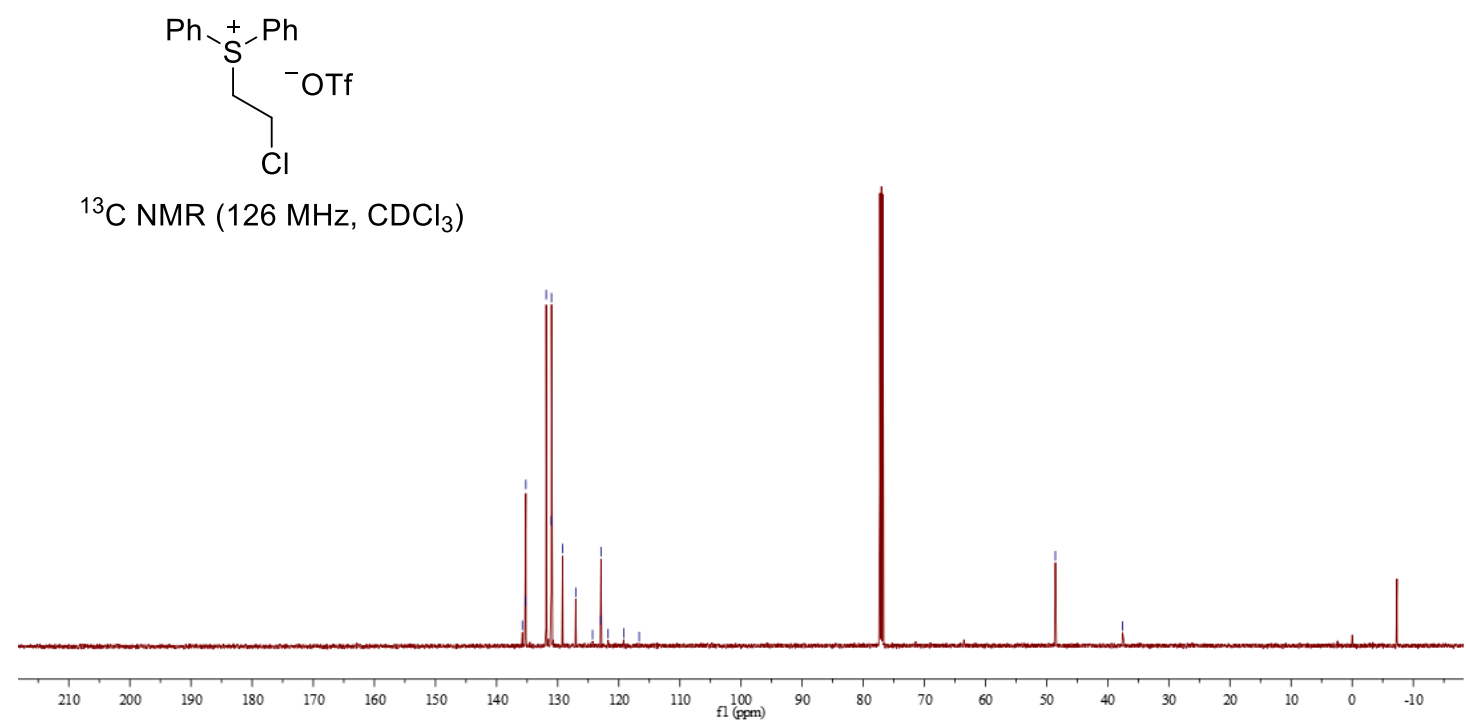

(2-Chloroethyl)diphenylsulfonium tetrafluoroborate (2e)

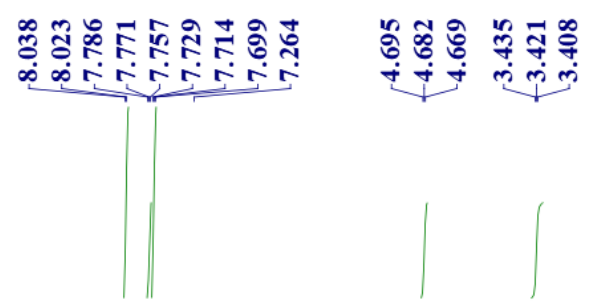

$\overbrace{\mathrm{Cl}}^{\mathrm{Ph}}{ }_{\mathrm{S}}^{+}-\mathrm{Ph}$

${ }^{1} \mathrm{H} \mathrm{NMR}\left(500 \mathrm{MHz}, \mathrm{CDCl}_{3}\right)$

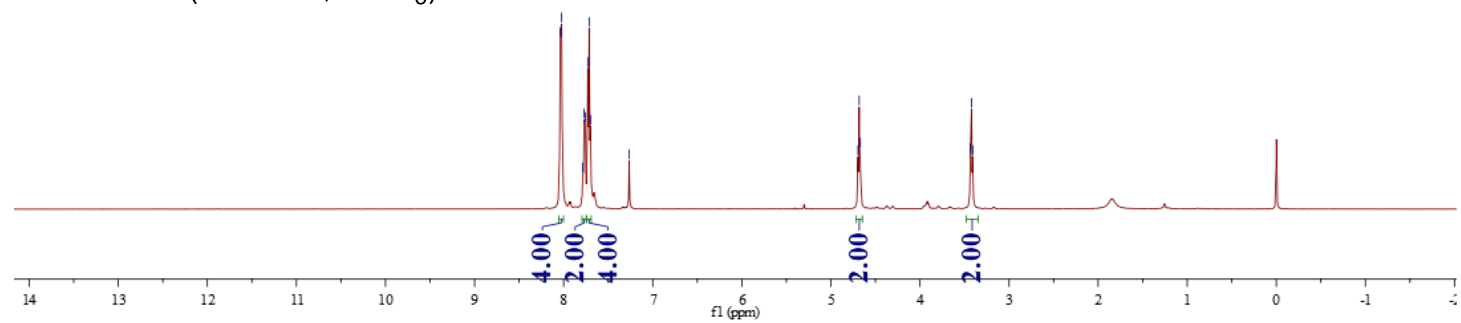




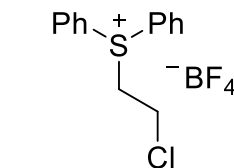

${ }^{19} \mathrm{~F}$ NMR $\left(471 \mathrm{MHz}, \mathrm{CDCl}_{3}\right)$

\begin{tabular}{|c|c|}
\hline 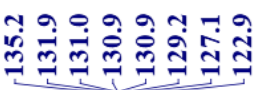 & 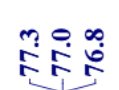 \\
\hline
\end{tabular}

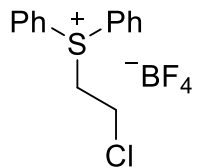

${ }^{13} \mathrm{C}$ NMR $\left(126 \mathrm{MHz}, \mathrm{CDCl}_{3}\right.$ )

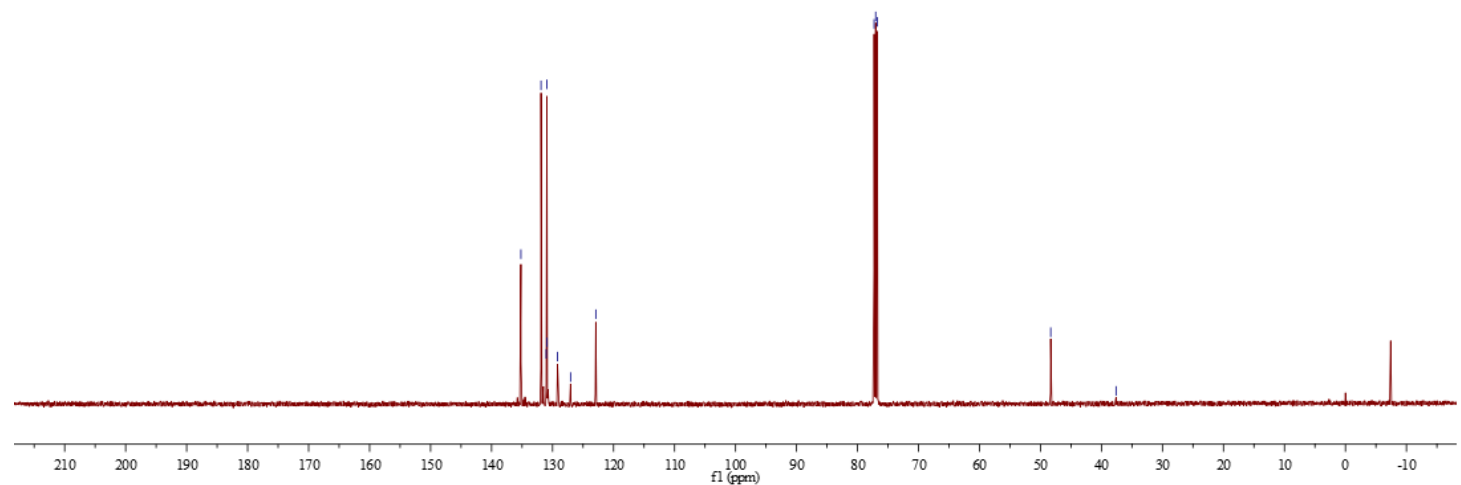


(2-Iodoethyl)diphenylsulfonium triflate (2f)
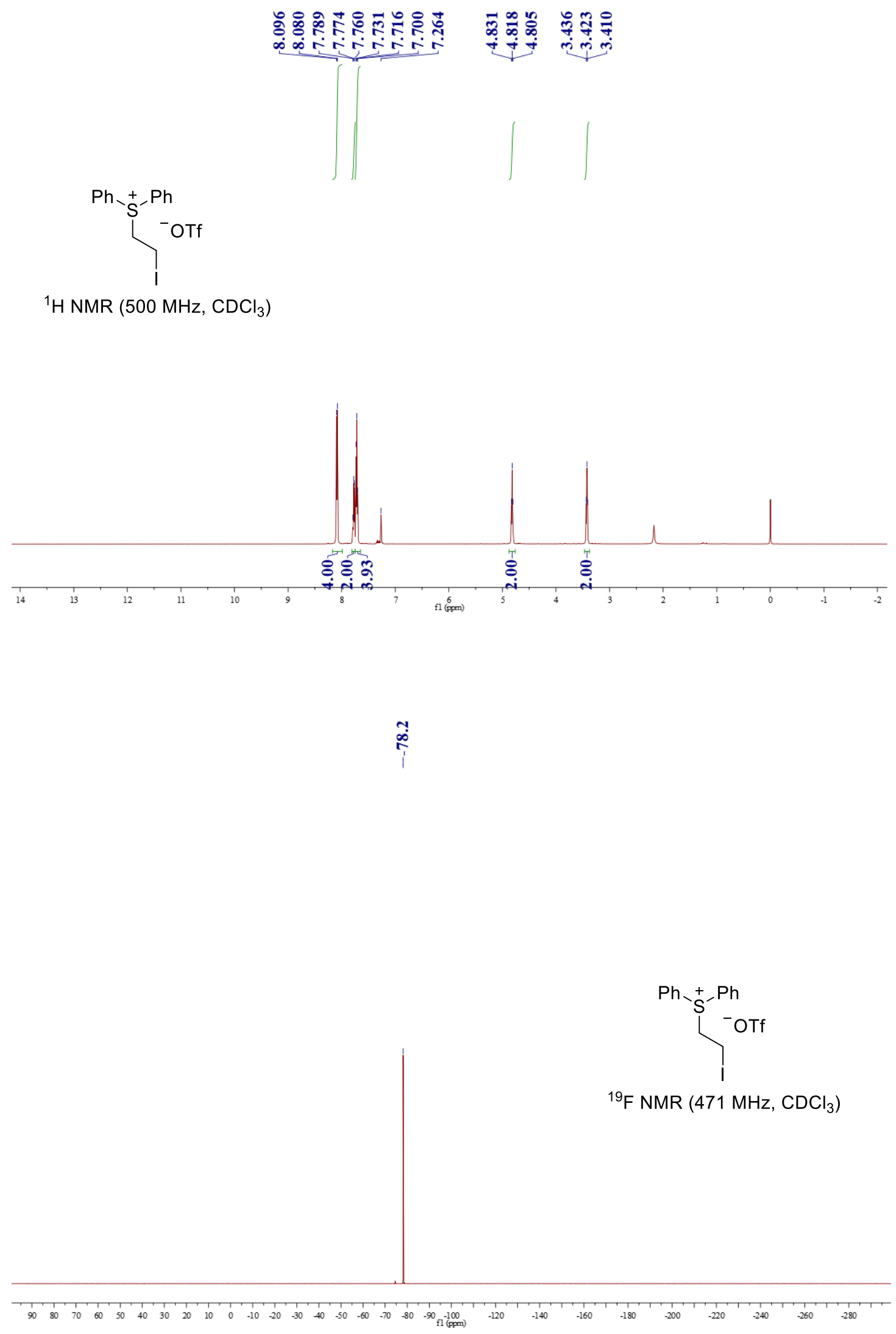


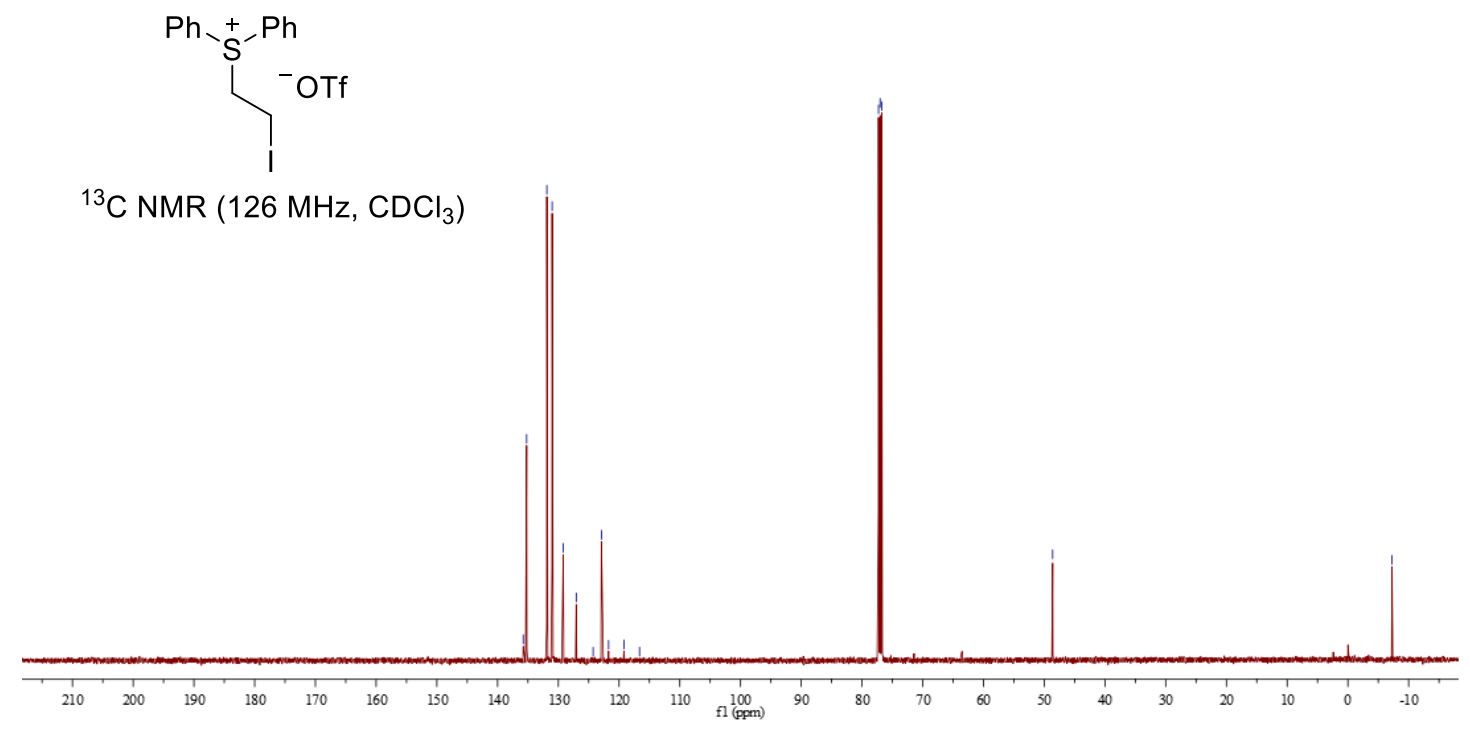

(2-Iodoethyl)diphenylsulfonium tetrafluoroborate (2g)

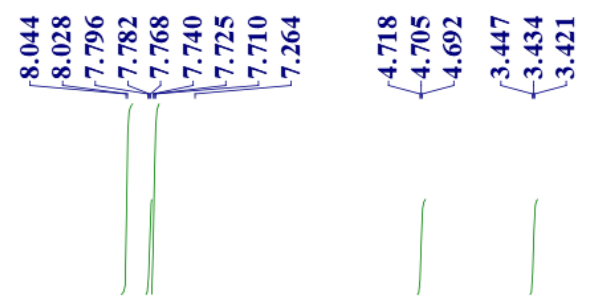

$\underbrace{\mathrm{Ph}-\mathrm{Ph}}_{-\mathrm{Sh}}$

${ }^{1} \mathrm{H}$ NMR $\left(500 \mathrm{MHz}, \mathrm{CDCl}_{3}\right)$

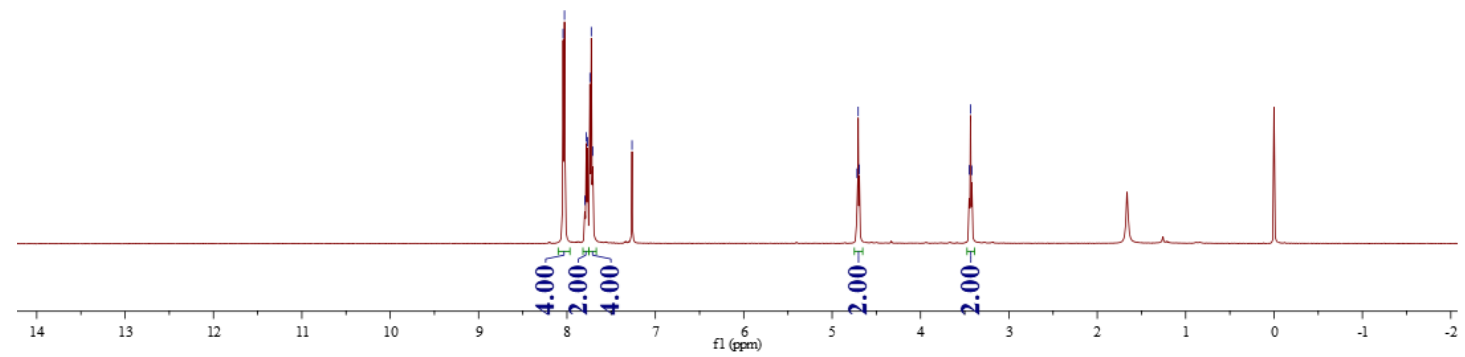




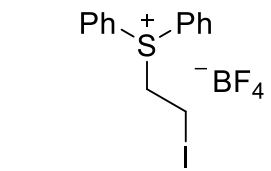

${ }^{19} \mathrm{~F}$ NMR $\left(471 \mathrm{MHz}, \mathrm{CDCl}_{3}\right)$

\begin{tabular}{|c|c|c|}
\hline 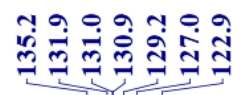 & 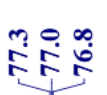 & $\begin{array}{l}n \\
\infty \\
\infty \\
+\infty\end{array}$ \\
\hline
\end{tabular}

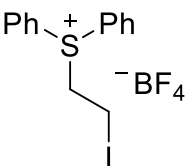

${ }^{13} \mathrm{C}$ NMR $\left(126 \mathrm{MHz}, \mathrm{CDCl}_{3}\right)$

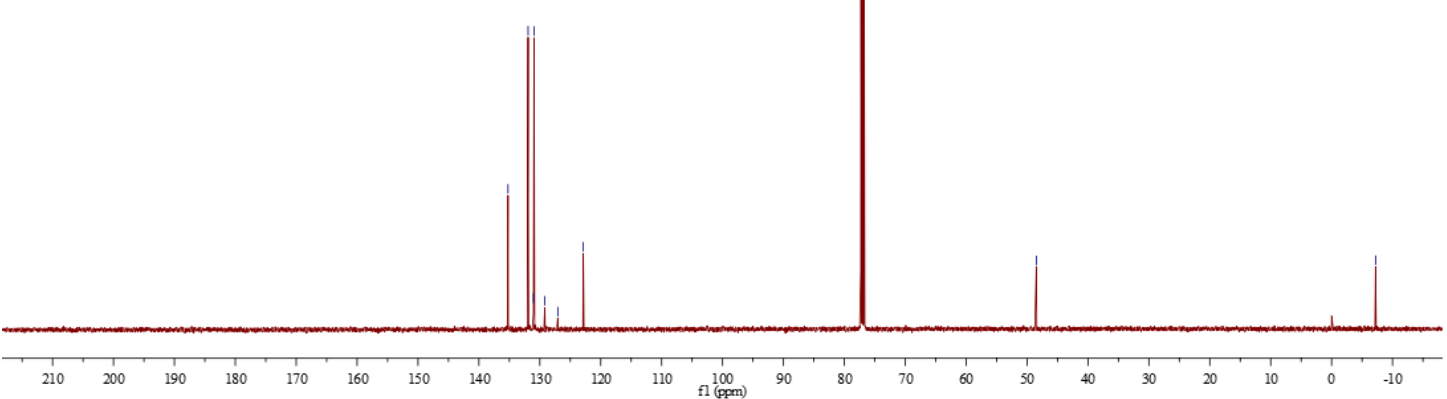


Diphenyl(2-(tosyloxy)ethyl)sulfonium triflate (2h)
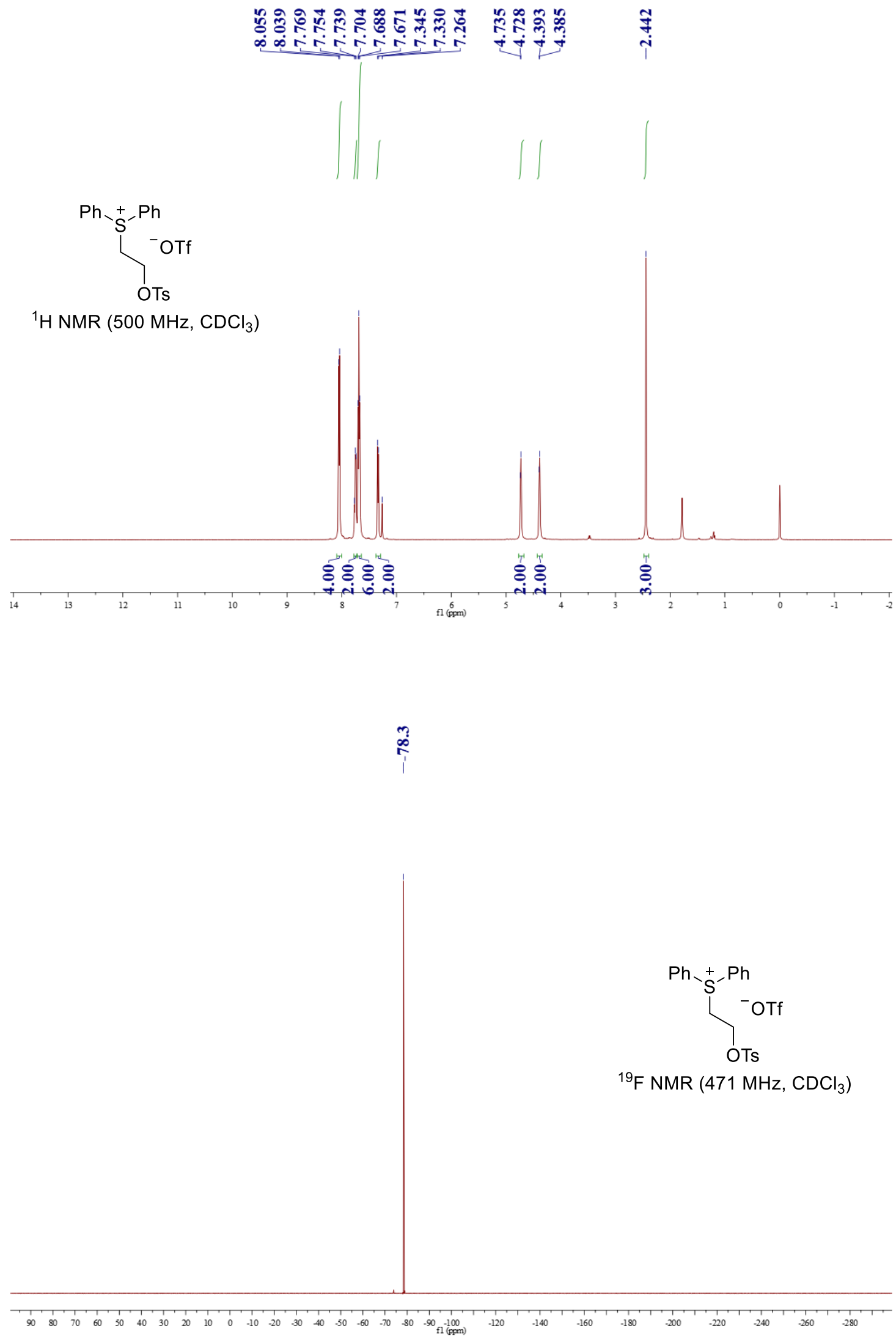


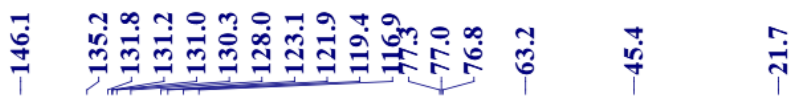

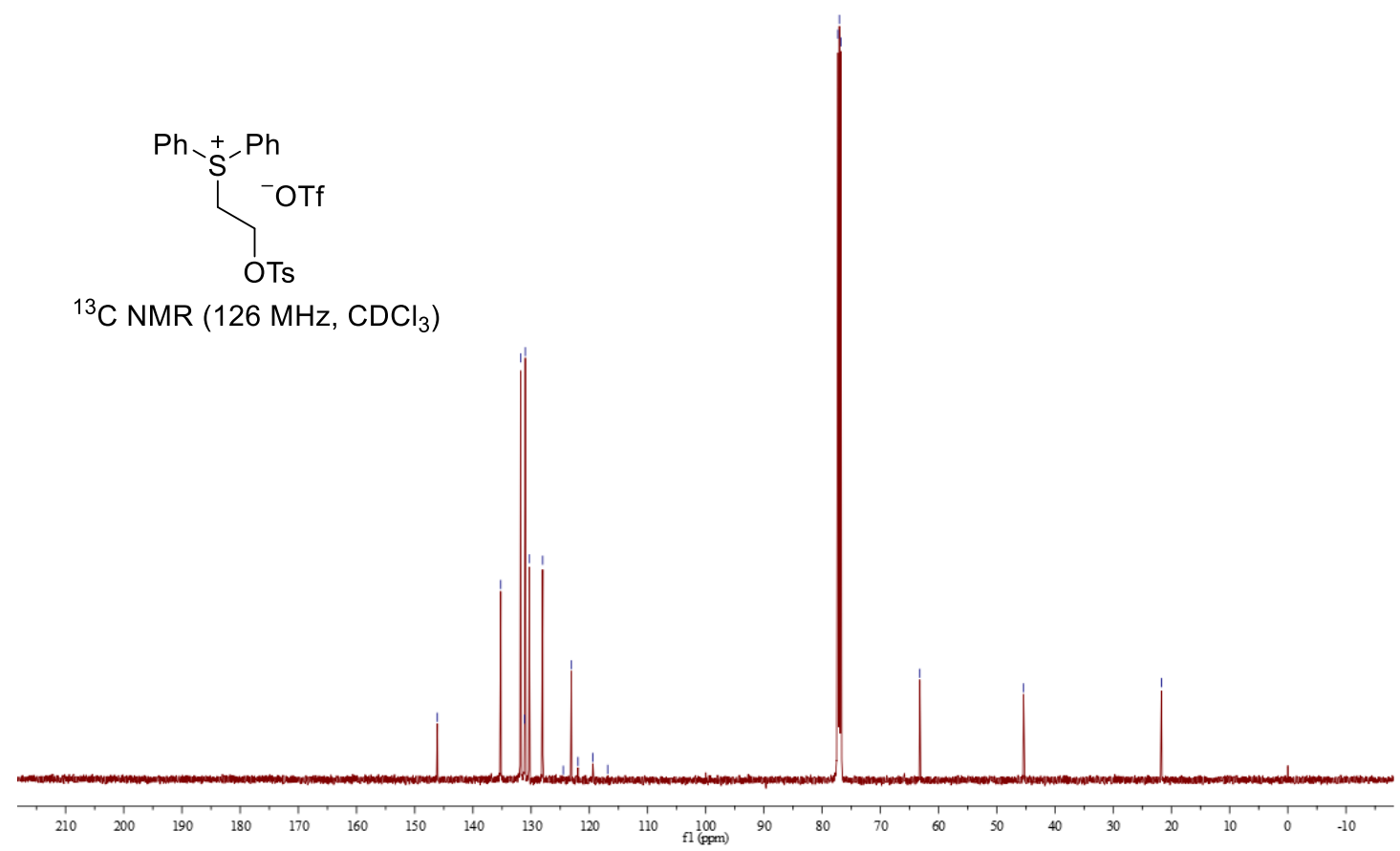

5-(2-Bromoethyl)-5H-thianthren-5-ium triflate (2i)
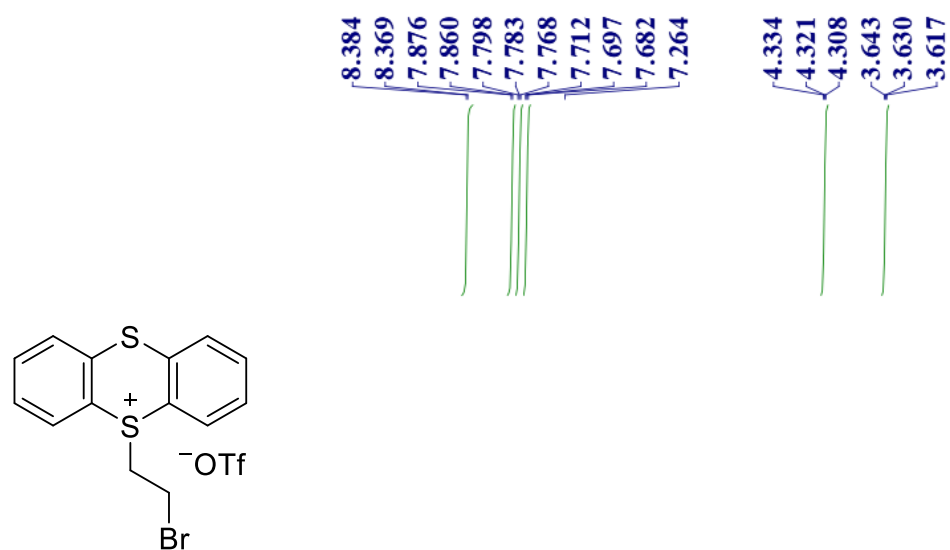

${ }^{1} \mathrm{H}$ NMR $\left(500 \mathrm{MHz}, \mathrm{CDCl}_{3}\right)$

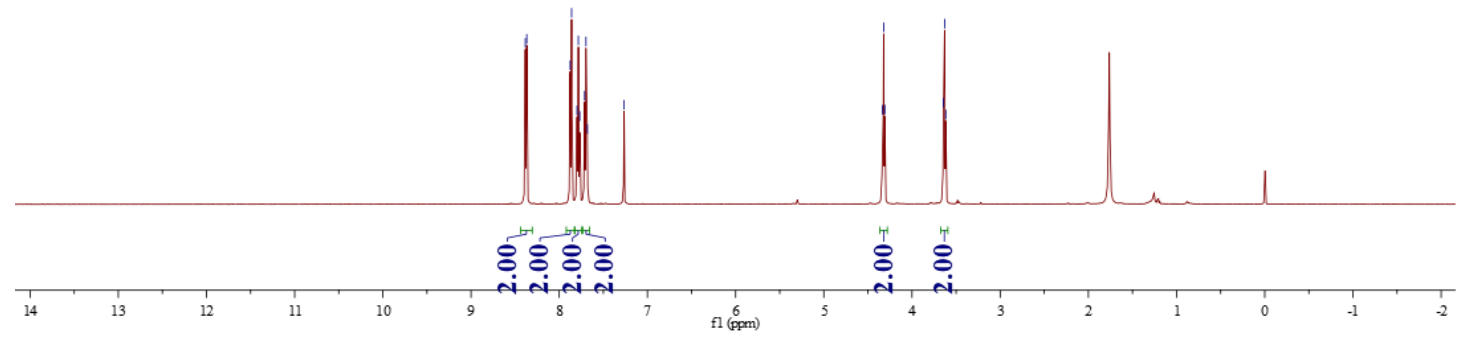



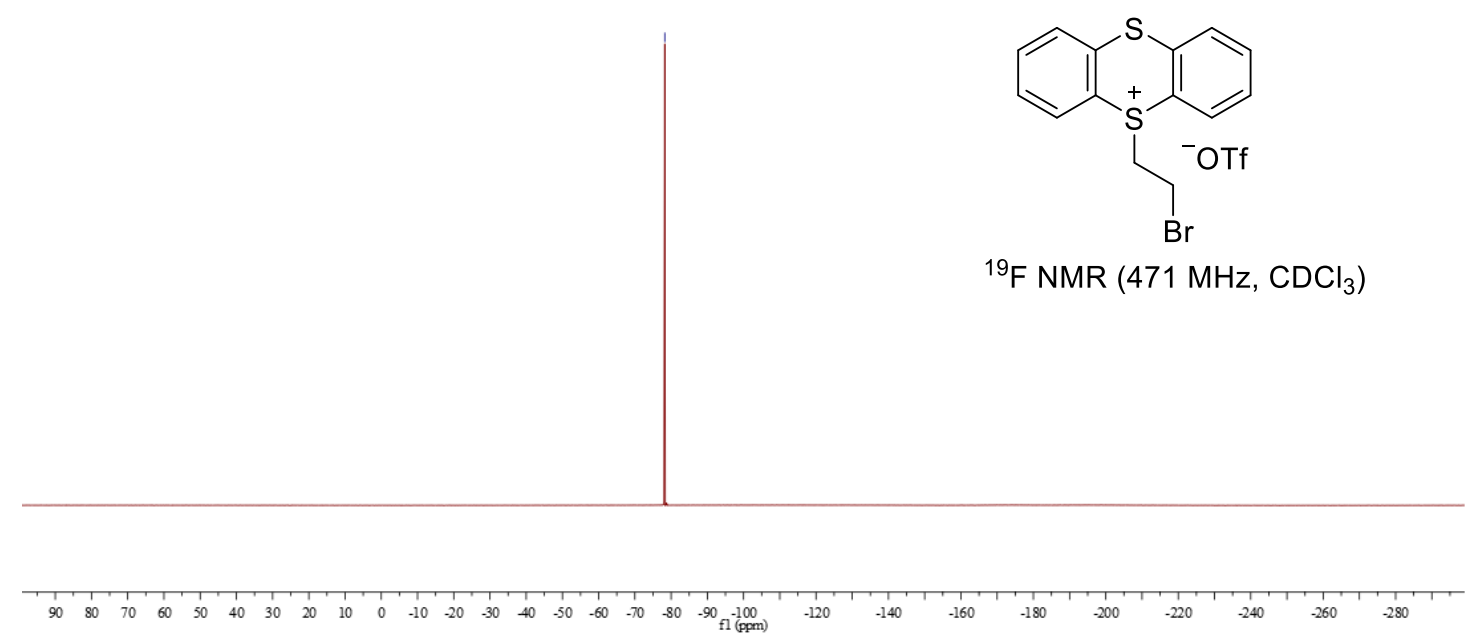

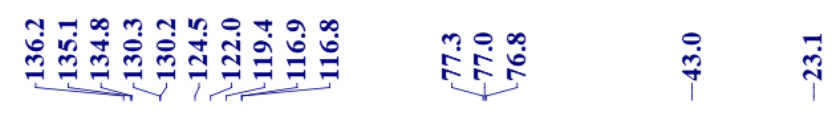

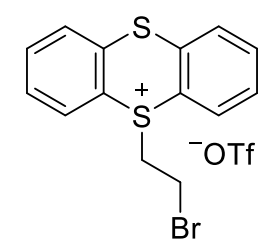

$\left.{ }^{13} \mathrm{C} \mathrm{NMR} \mathrm{(126} \mathrm{MHz,} \mathrm{CDCl}_{3}\right)$

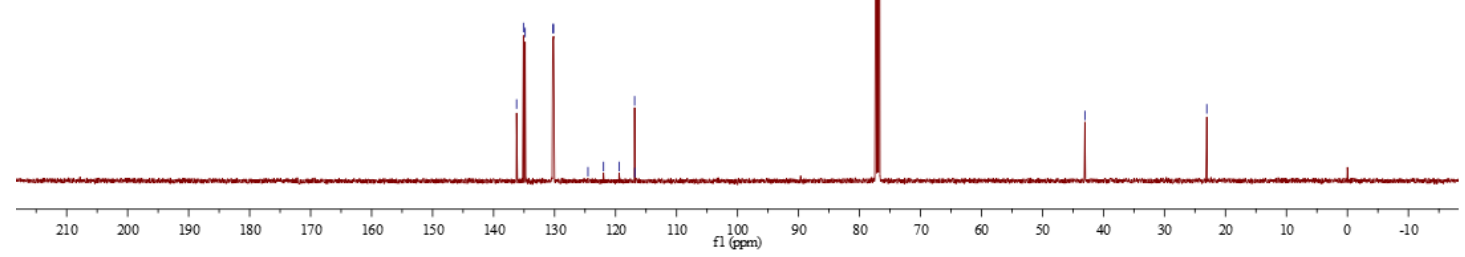


1-(2-Bromoethyl)tetrahydro-1H-thiophen-1-ium triflate $(\mathbf{2} \mathbf{j})$
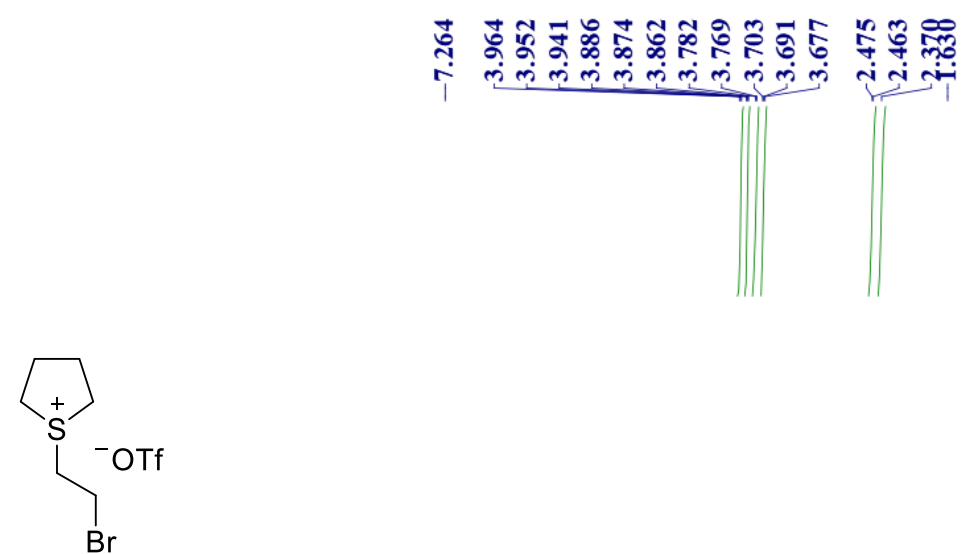

${ }^{1} \mathrm{H}$ NMR $\left(500 \mathrm{MHz}, \mathrm{CDCl}_{3}\right)$
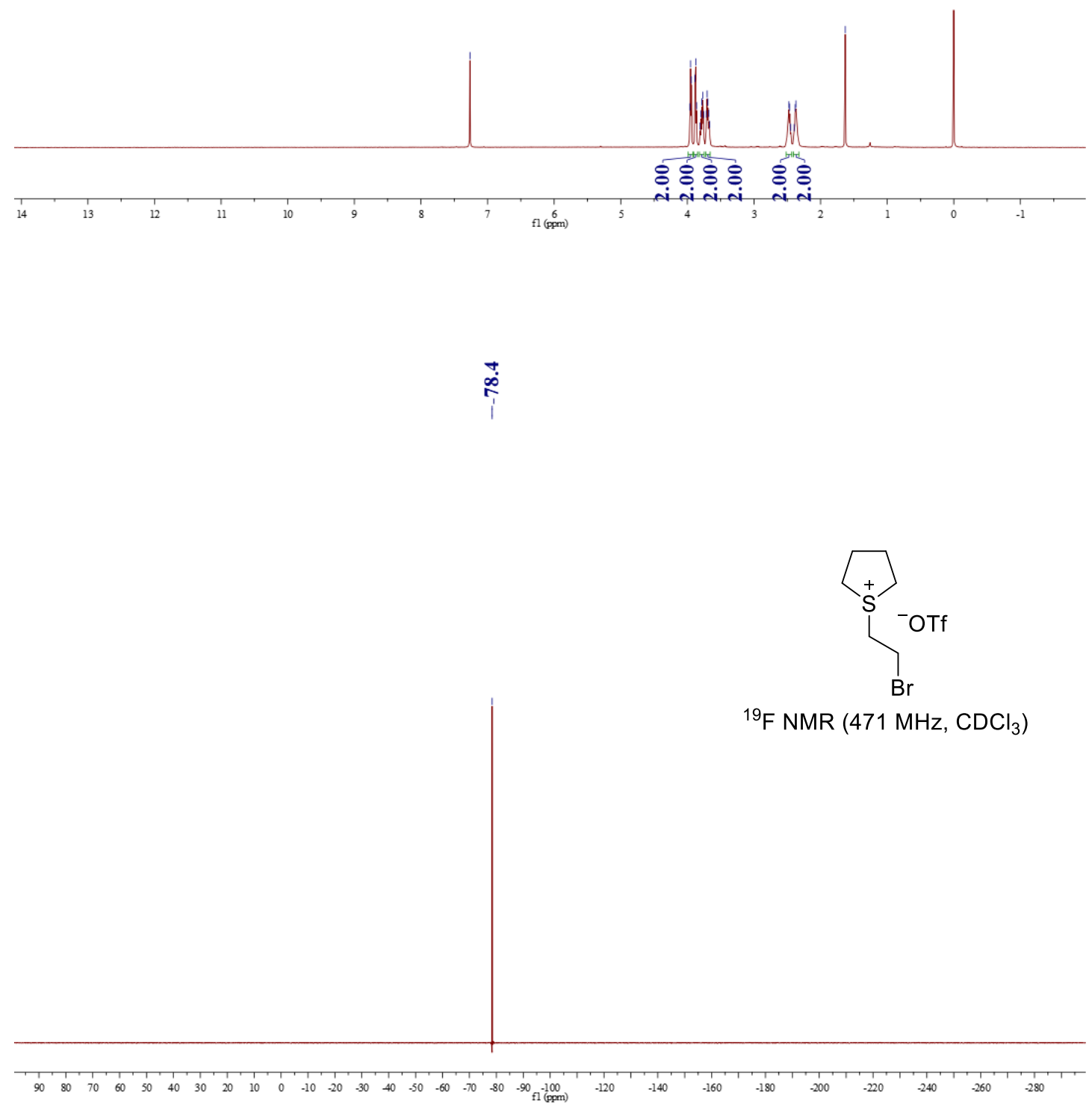

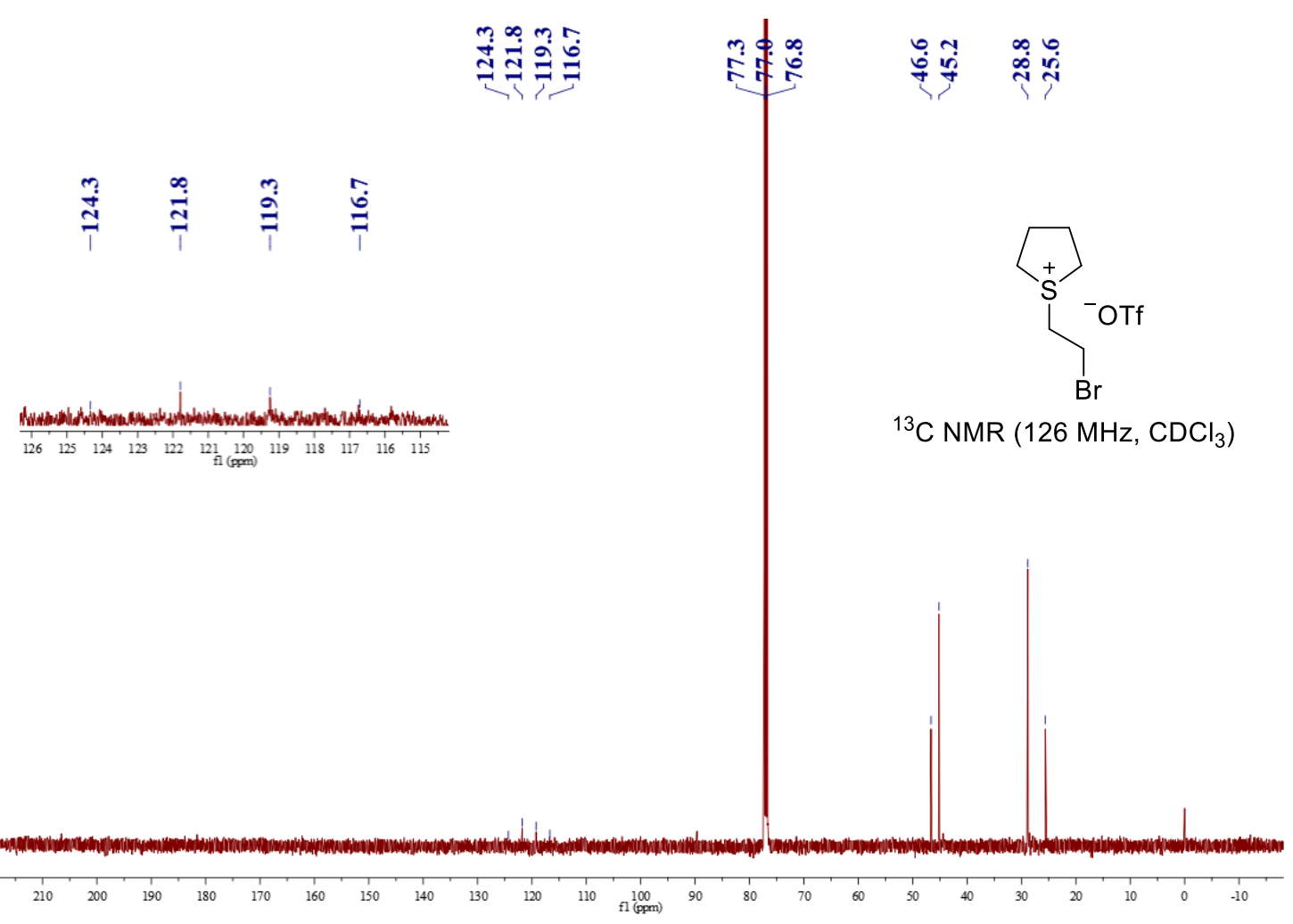

But-3-en-1-yn-1-ylbenzene (3a)

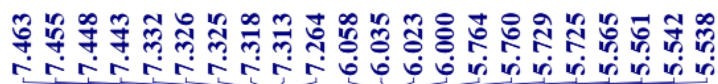

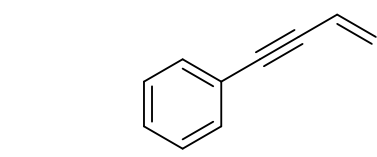

$\left.{ }^{1} \mathrm{H} \mathrm{NMR} \mathrm{(500} \mathrm{MHz,} \mathrm{CDCl}_{3}\right)$

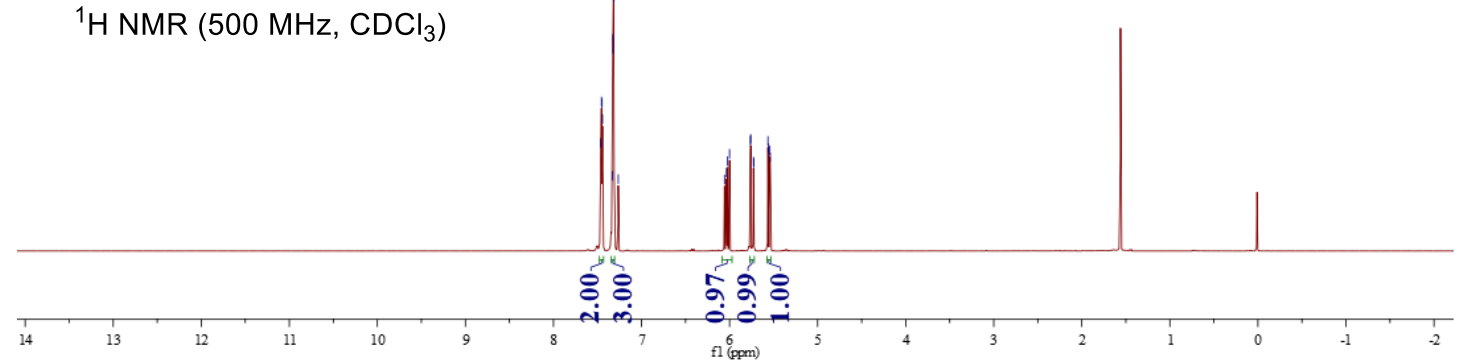




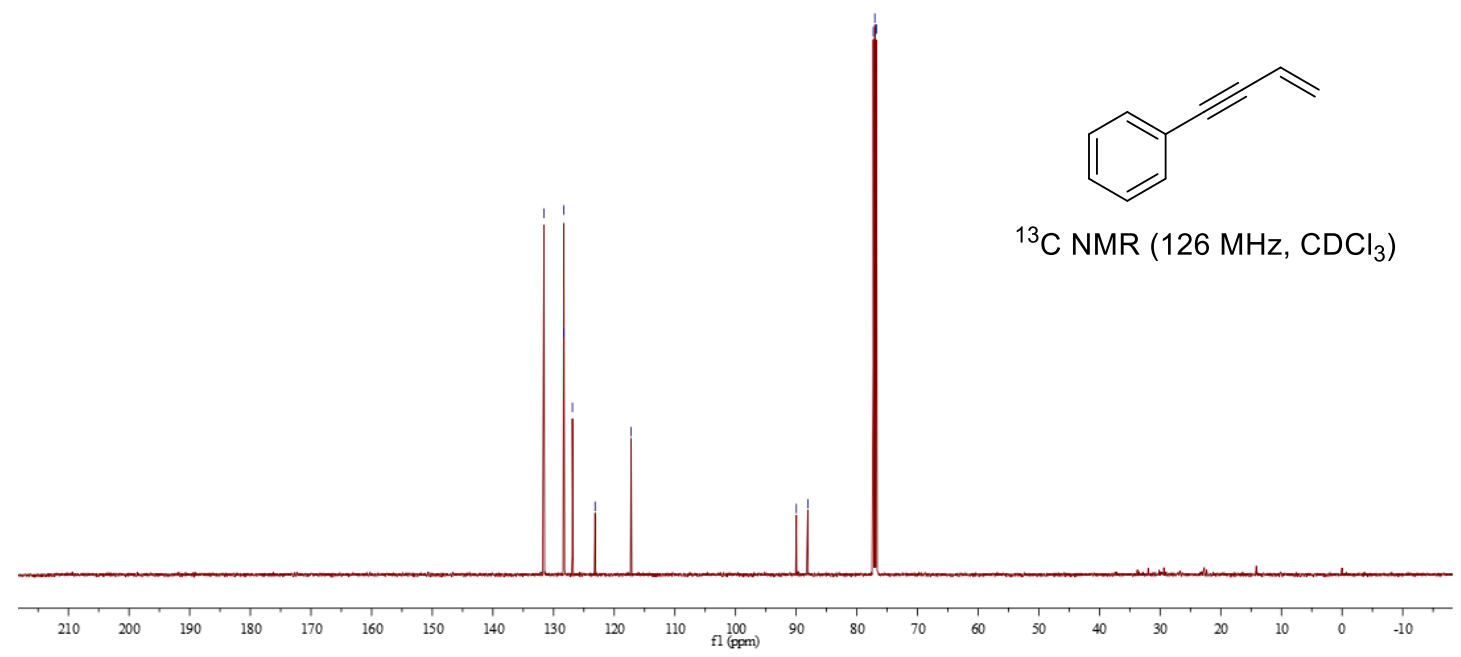

1-(But-3-en-1-yn-1-yl)-4-chlorobenzene (3b)
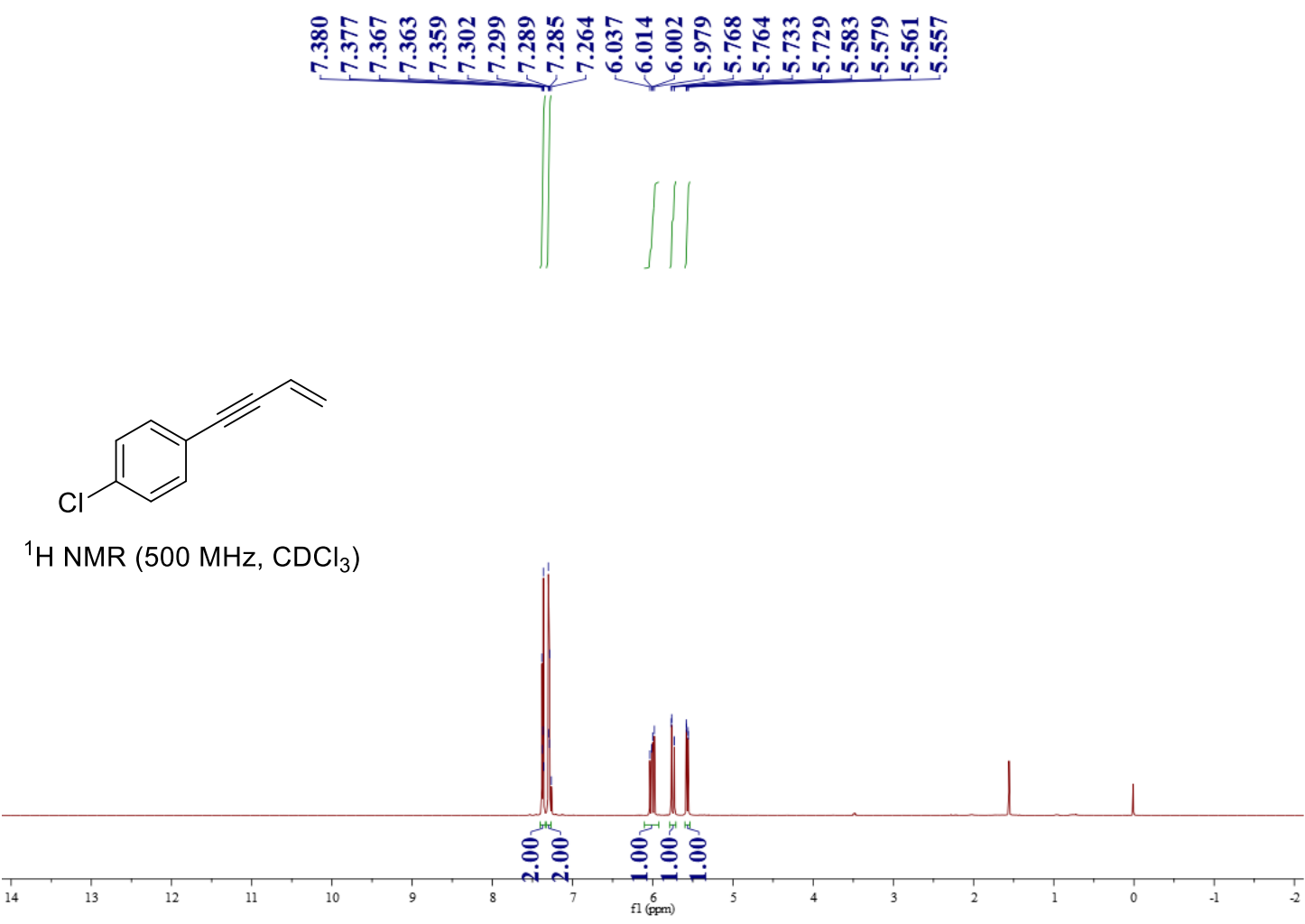


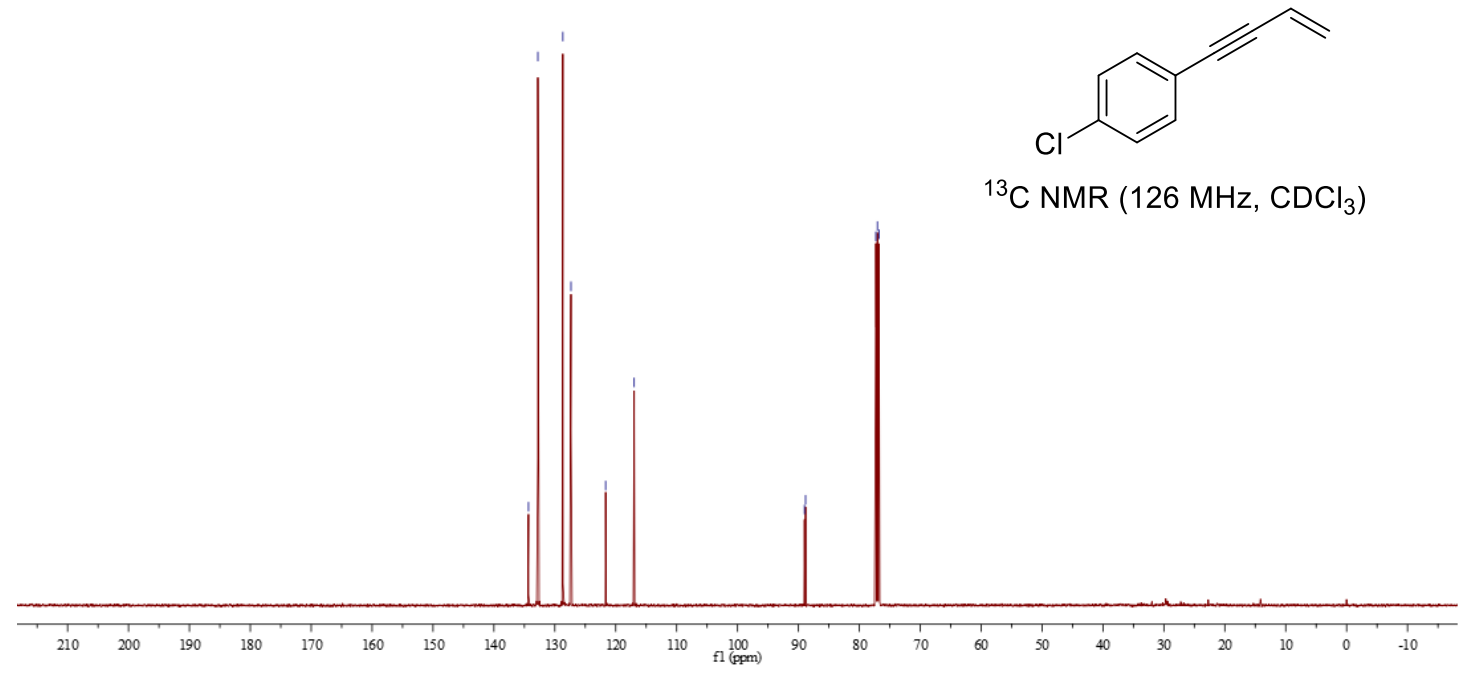

1-Bromo-4-(but-3-en-1-yn-1-yl)benzene (3c)
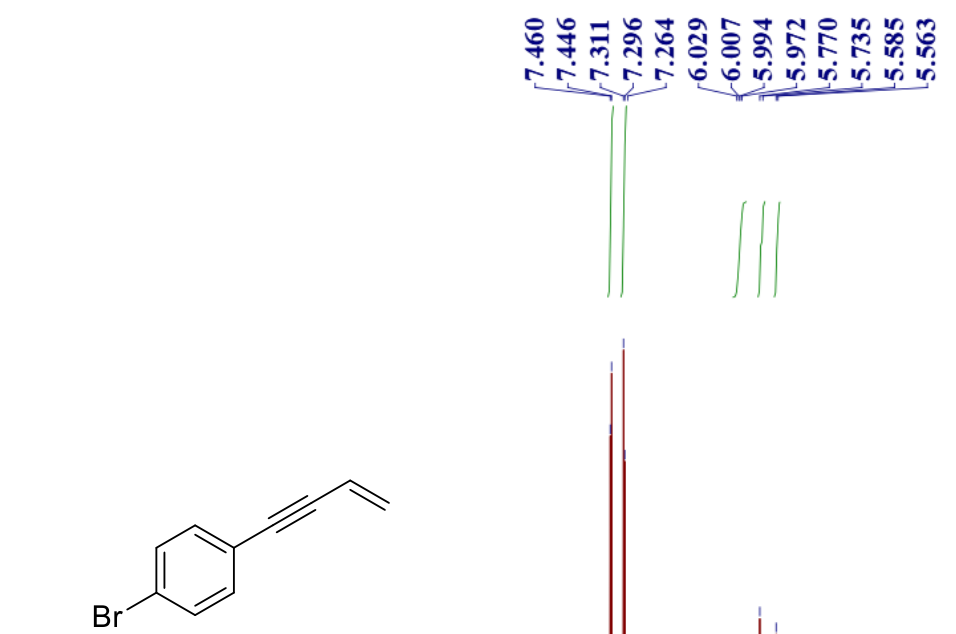

${ }^{1} \mathrm{H}$ NMR $\left(500 \mathrm{MHz}, \mathrm{CDCl}_{3}\right.$ )

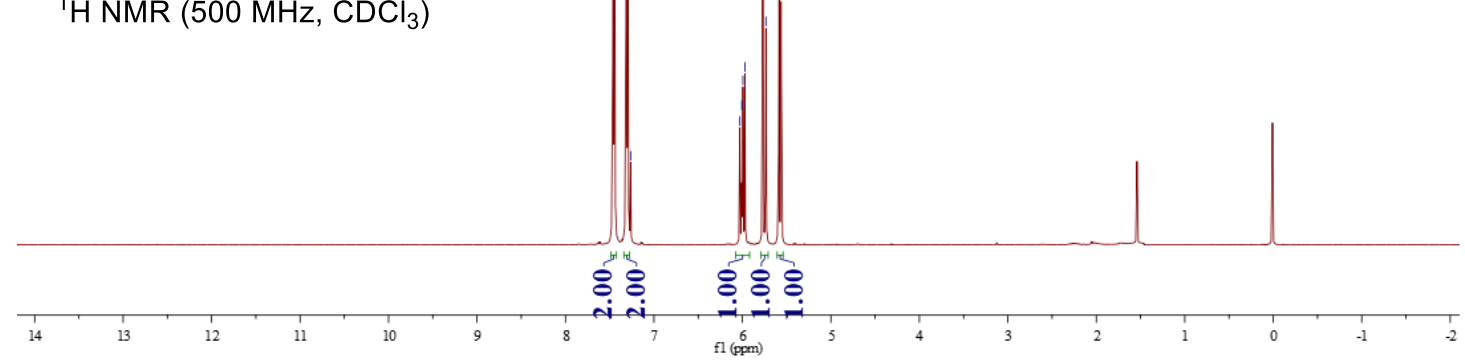




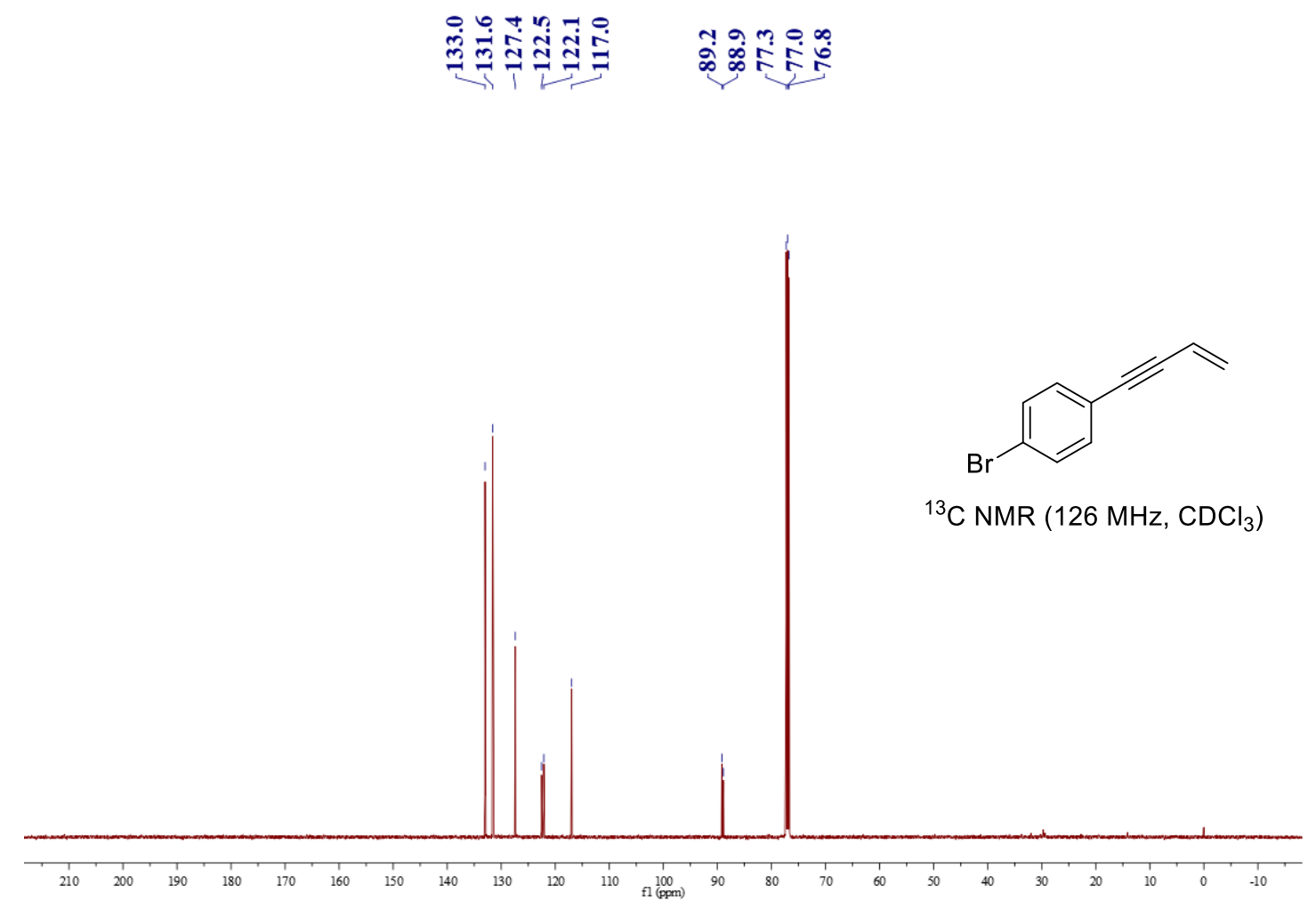

1-(But-3-en-1-yn-1-yl)-4-iodobenzene (3d)

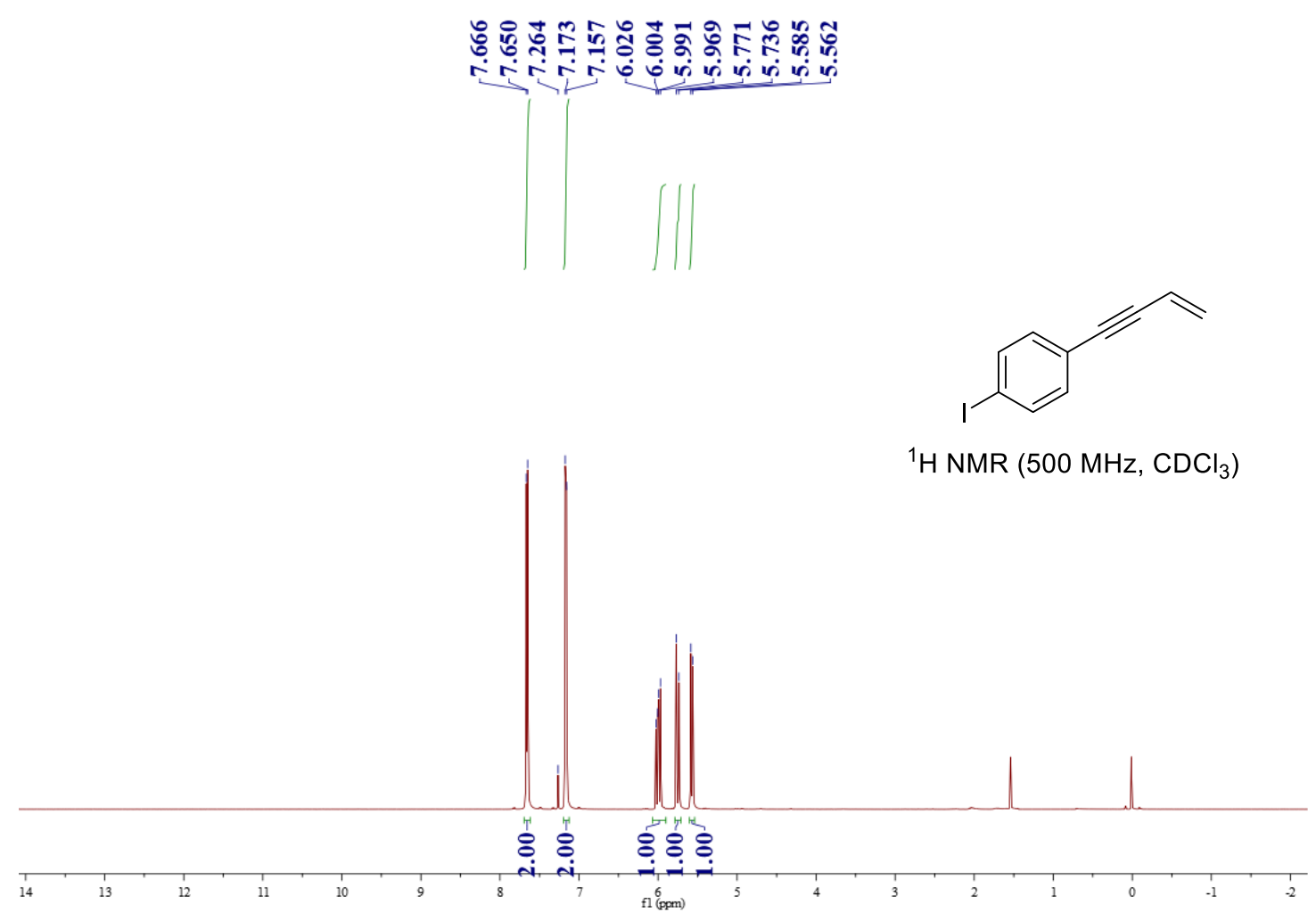




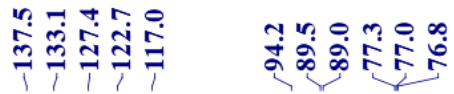
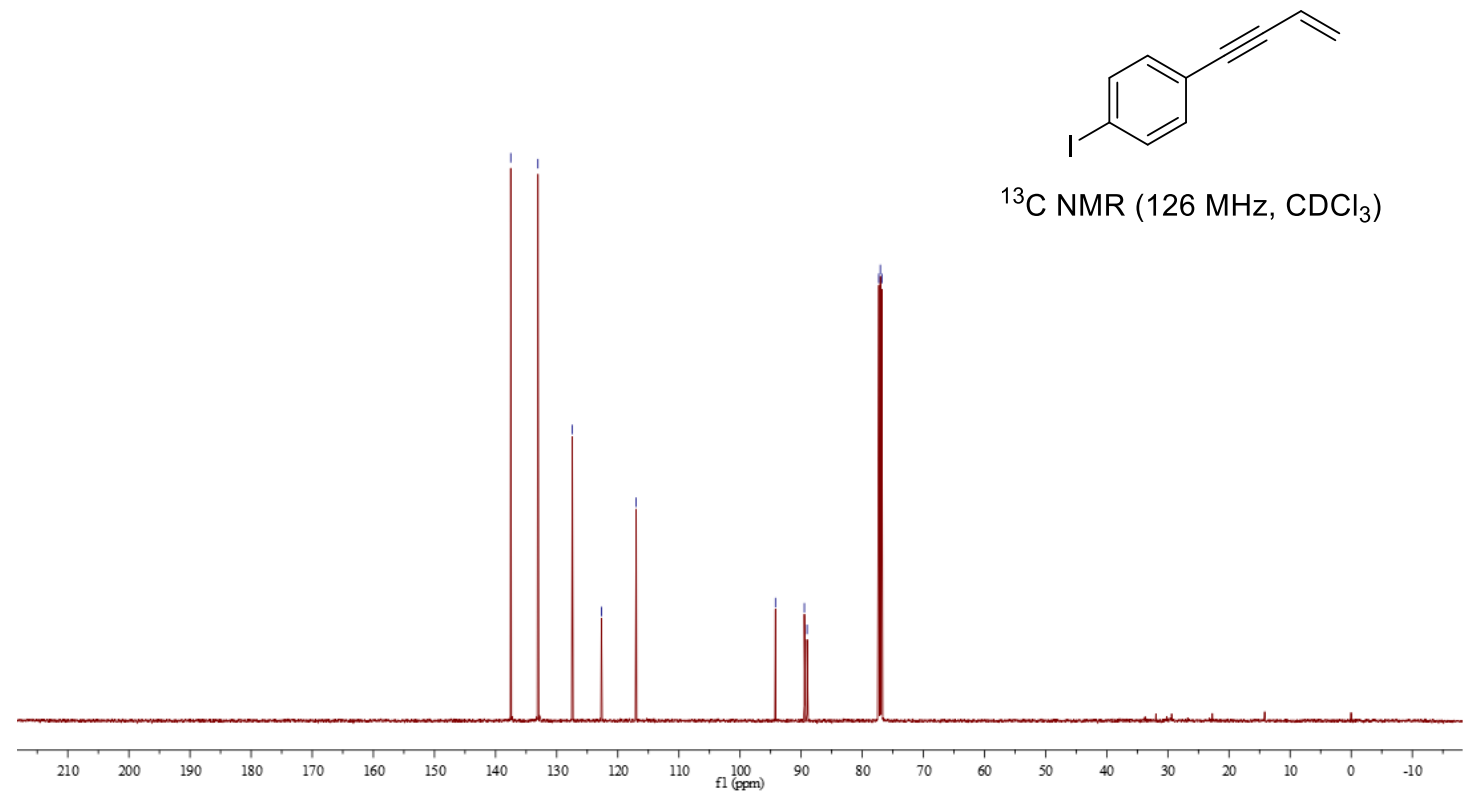

${ }^{3} \mathrm{C}$ NMR $\left(126 \mathrm{MHz}, \mathrm{CDCl}_{3}\right)$

1-(But-3-en-1-yn-1-yl)-4-(trifluoromethyl)benzene (3e)

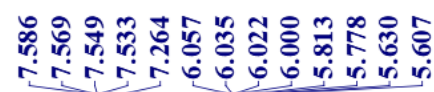

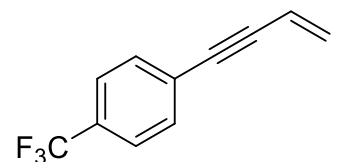

${ }^{1} \mathrm{H}$ NMR $\left(500 \mathrm{MHz}, \mathrm{CDCl}_{3}\right)$

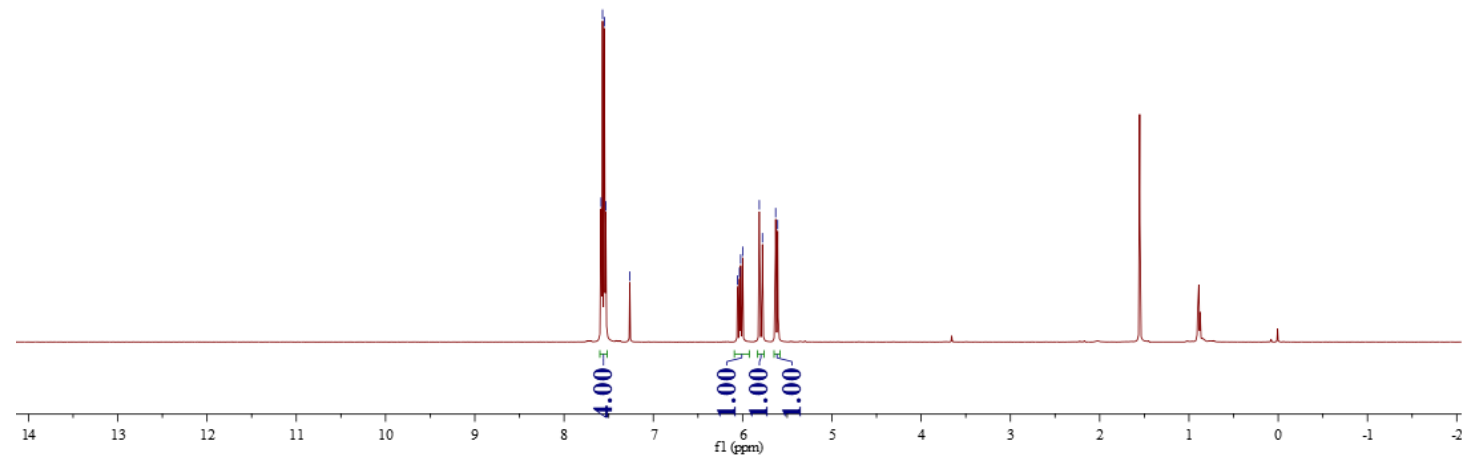




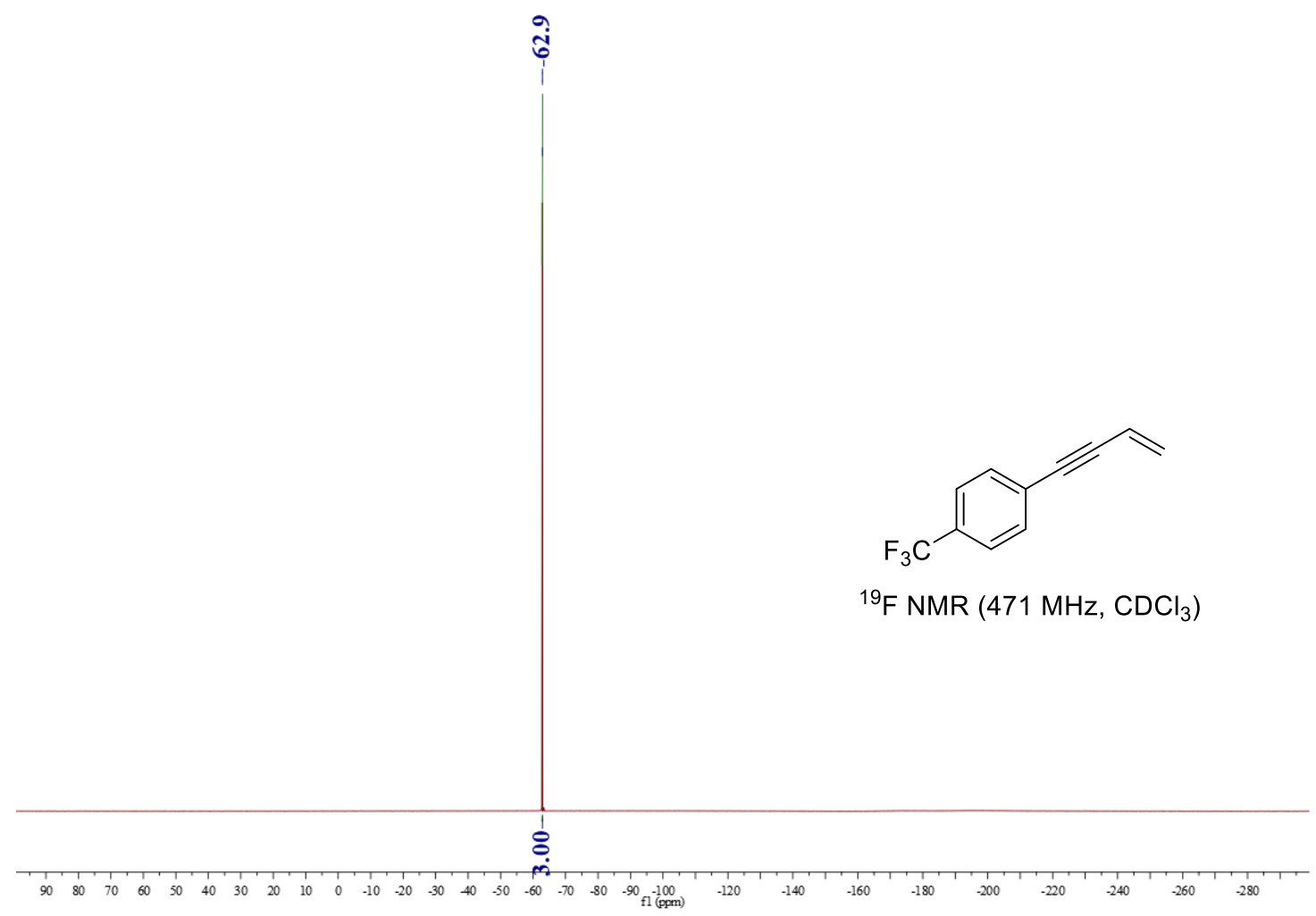

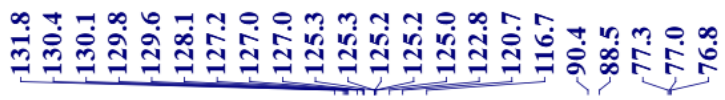

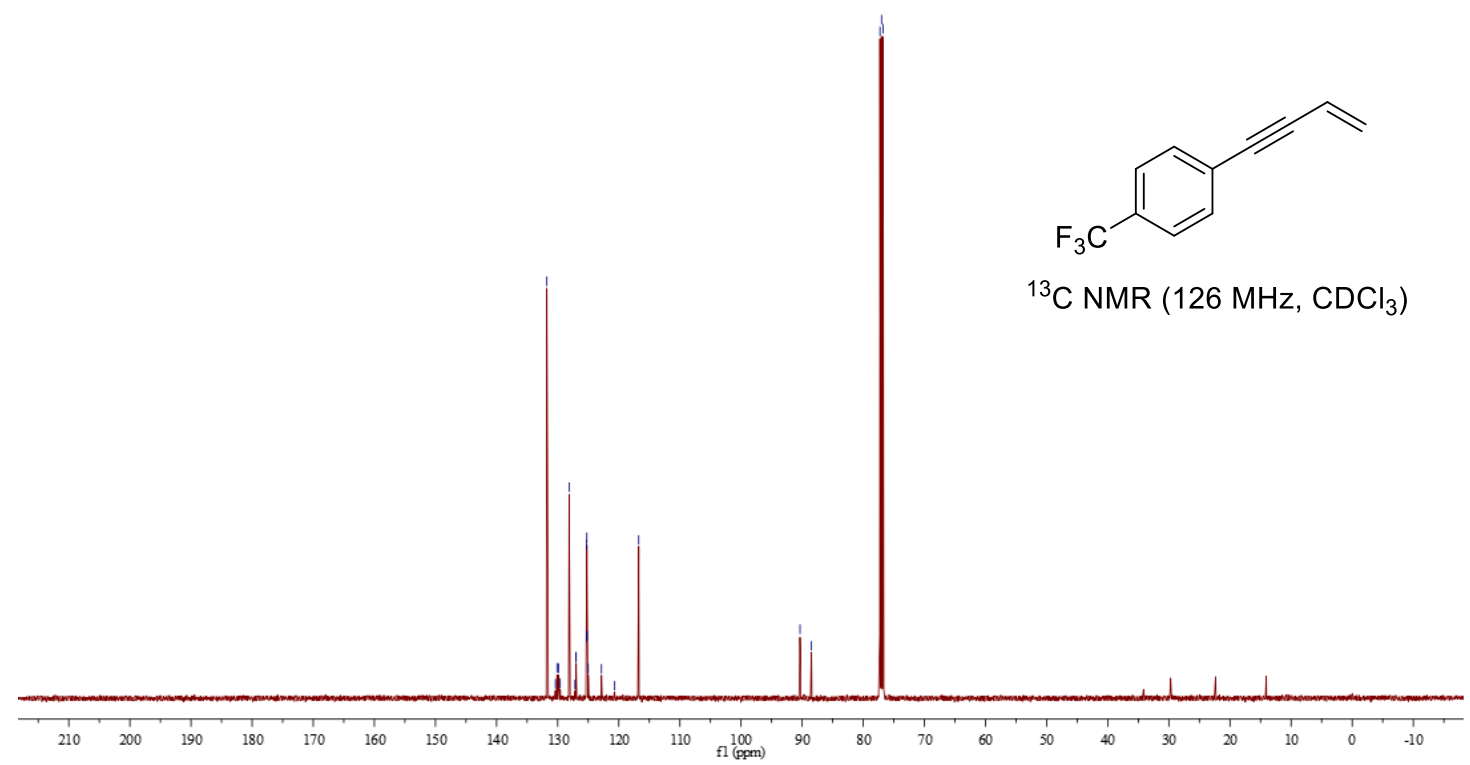


1-(But-3-en-1-yn-1-yl)-4-nitrobenzene (3f)

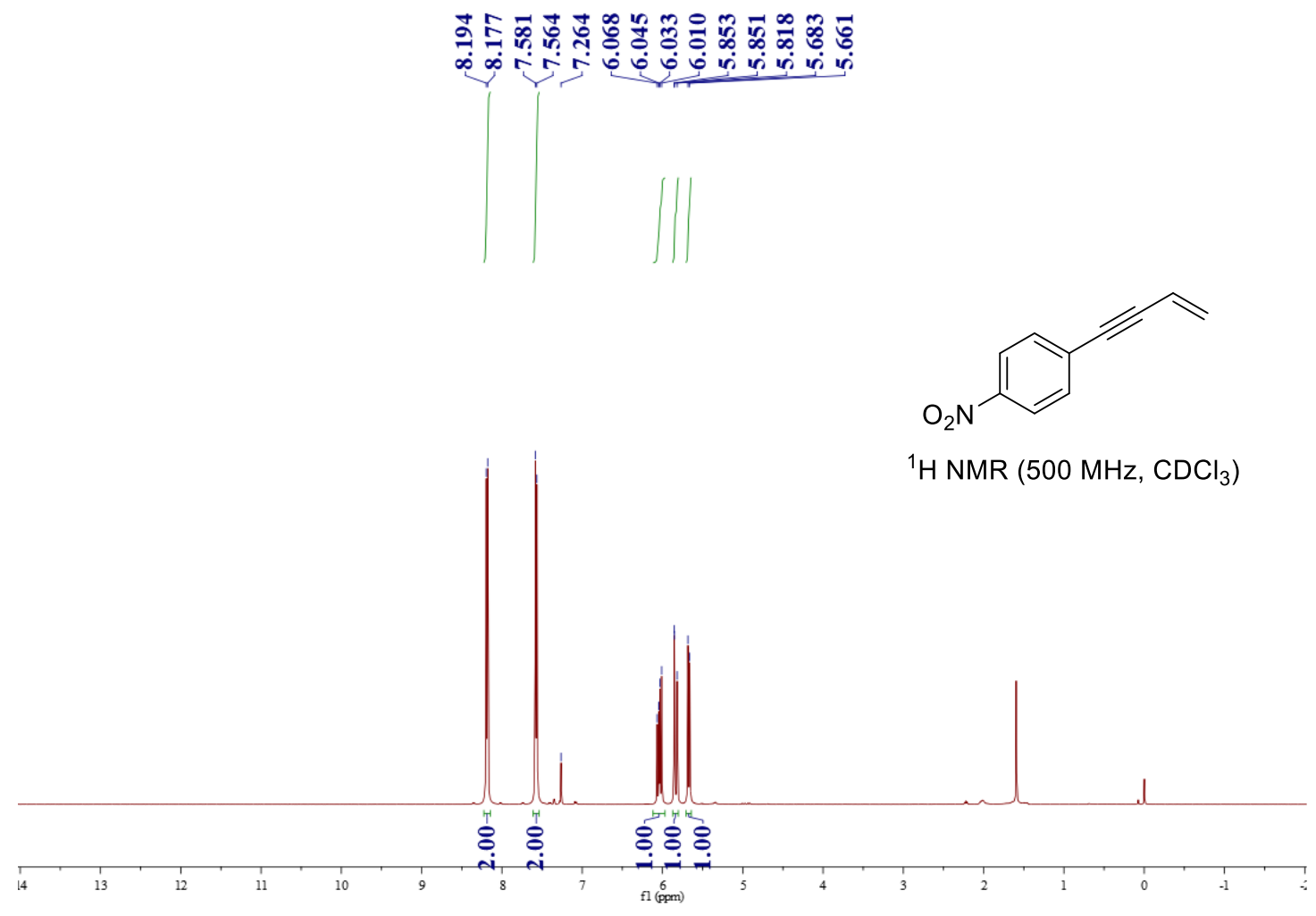

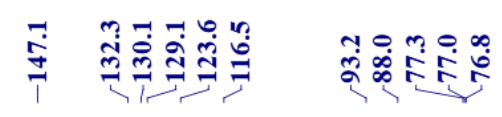

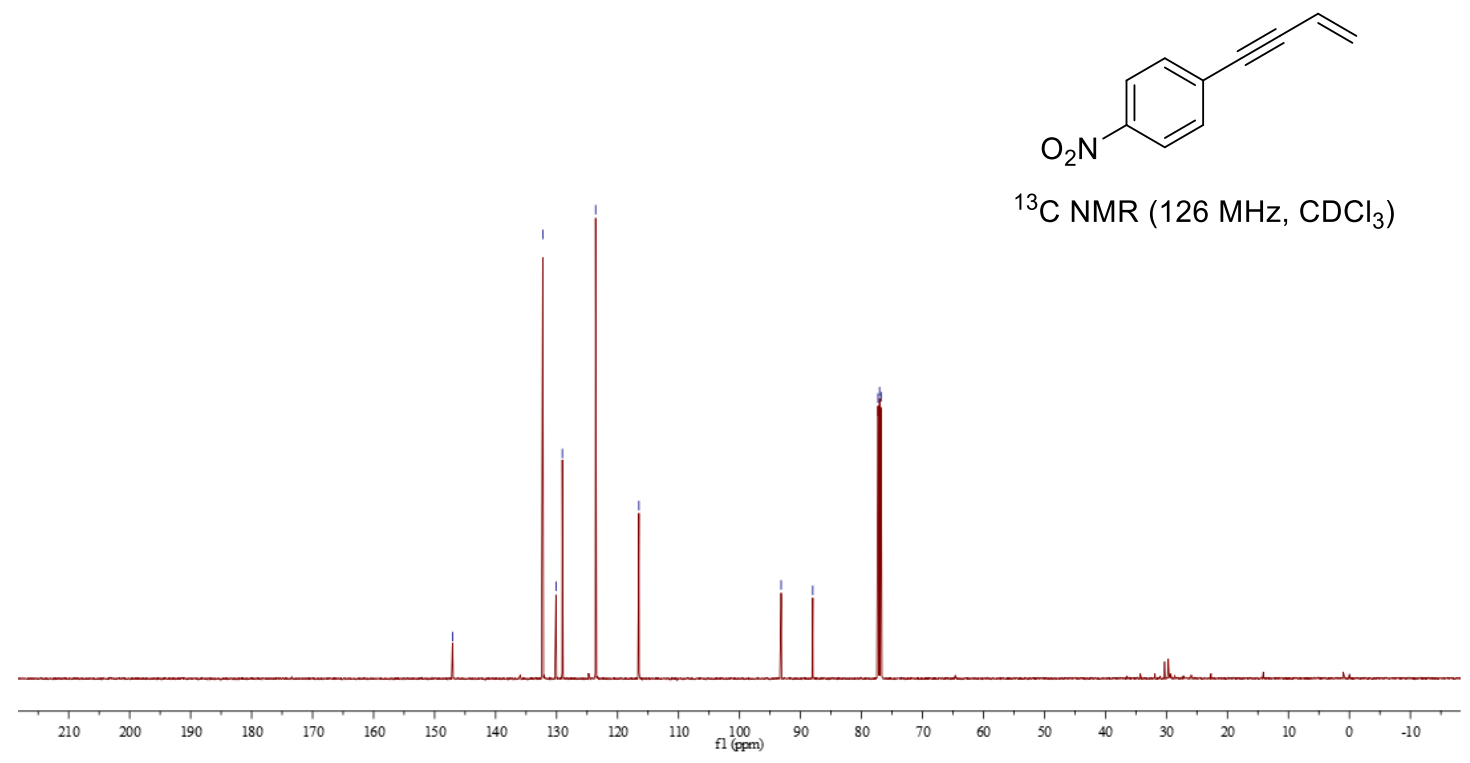


4-(But-3-en-1-yn-1-yl)benzonitrile (3g)

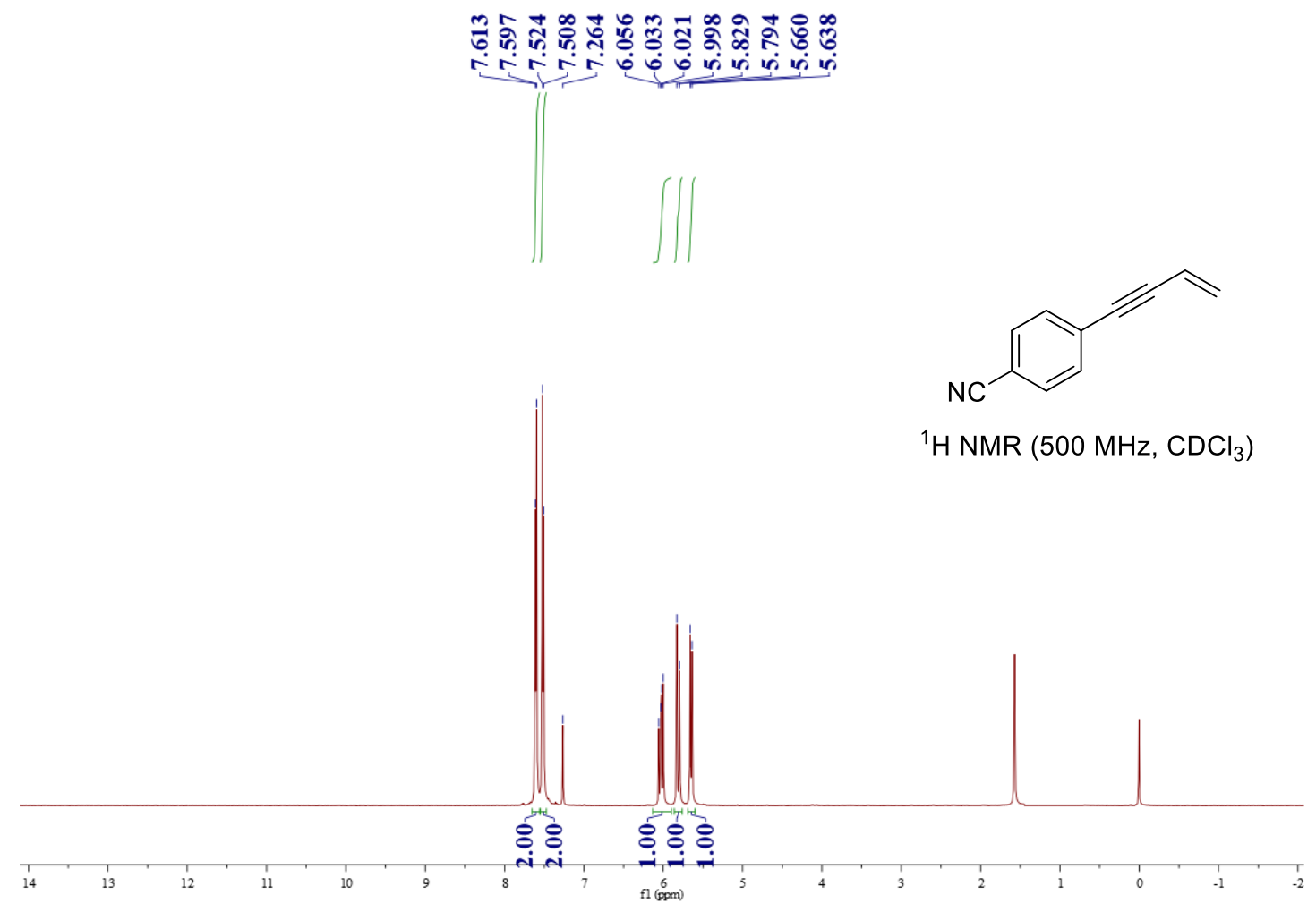

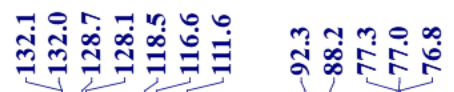

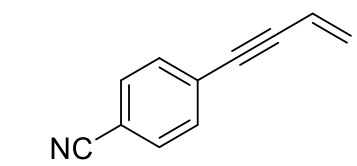

${ }^{13} \mathrm{C}$ NMR $\left(126 \mathrm{MHz}, \mathrm{CDCl}_{3}\right)$ 
1-(4-(But-3-en-1-yn-1-yl)phenyl)ethan-1-one (3h)
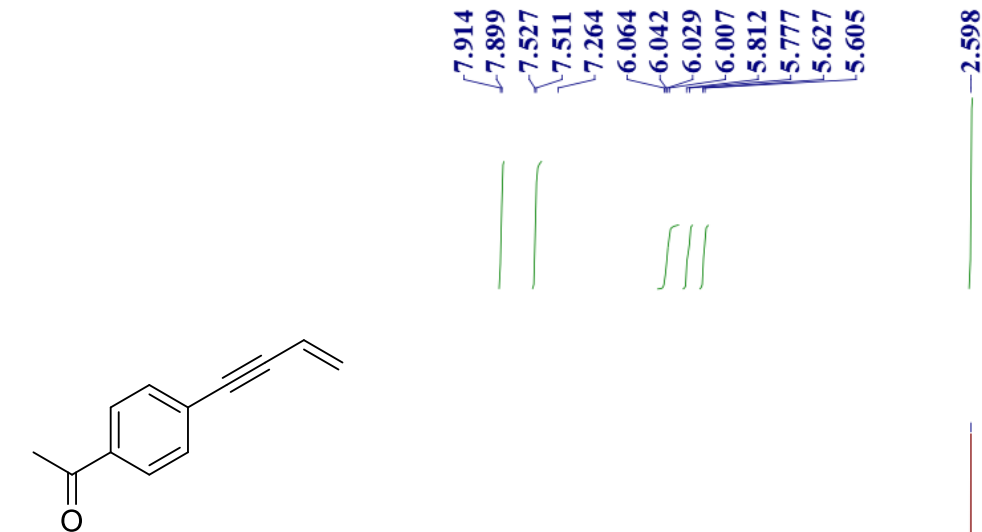

${ }^{1} \mathrm{H} \mathrm{NMR}\left(500 \mathrm{MHz}, \mathrm{CDCl}_{3}\right)$
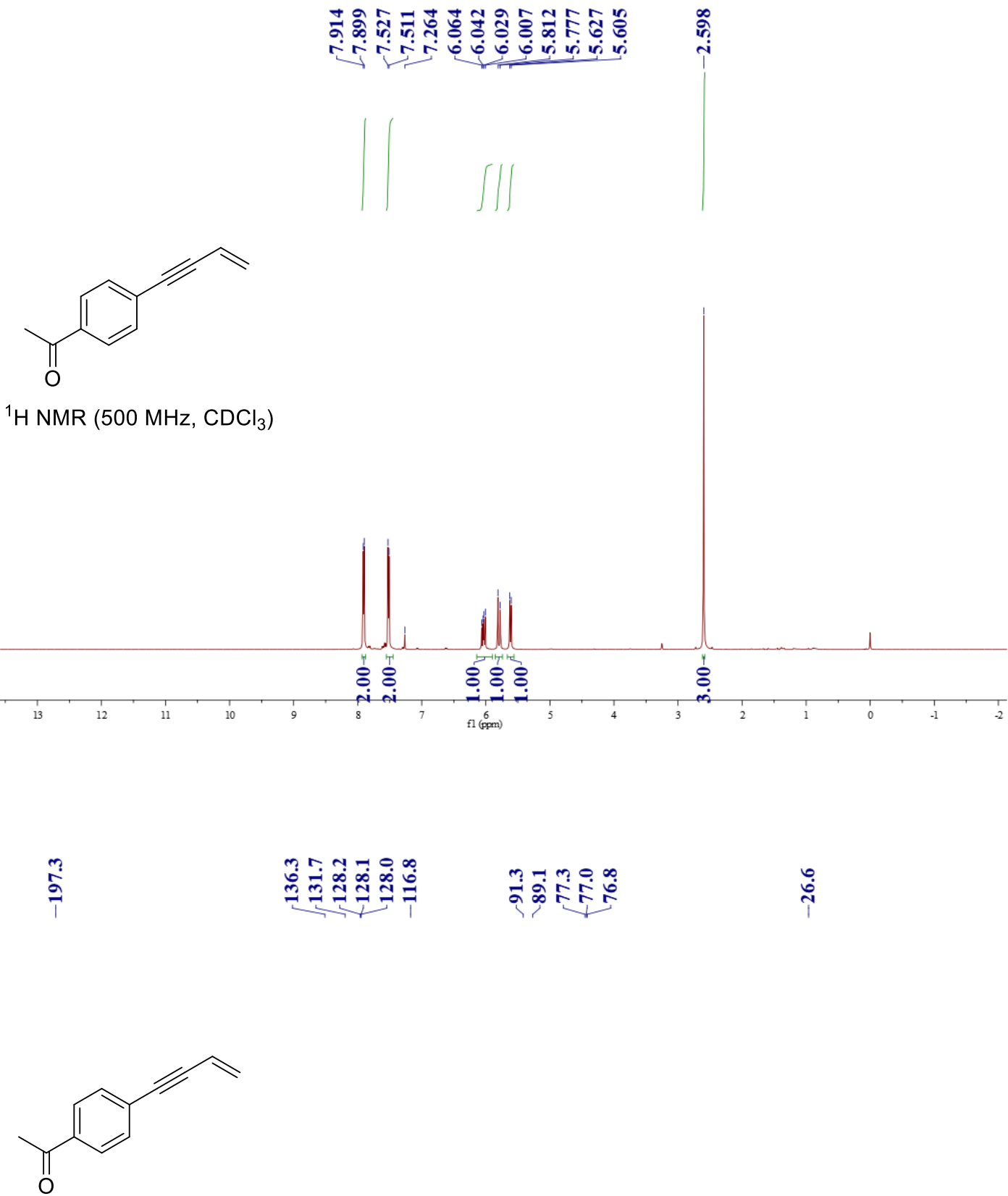

${ }^{13} \mathrm{C}$ NMR $\left(126 \mathrm{MHz}, \mathrm{CDCl}_{3}\right)$

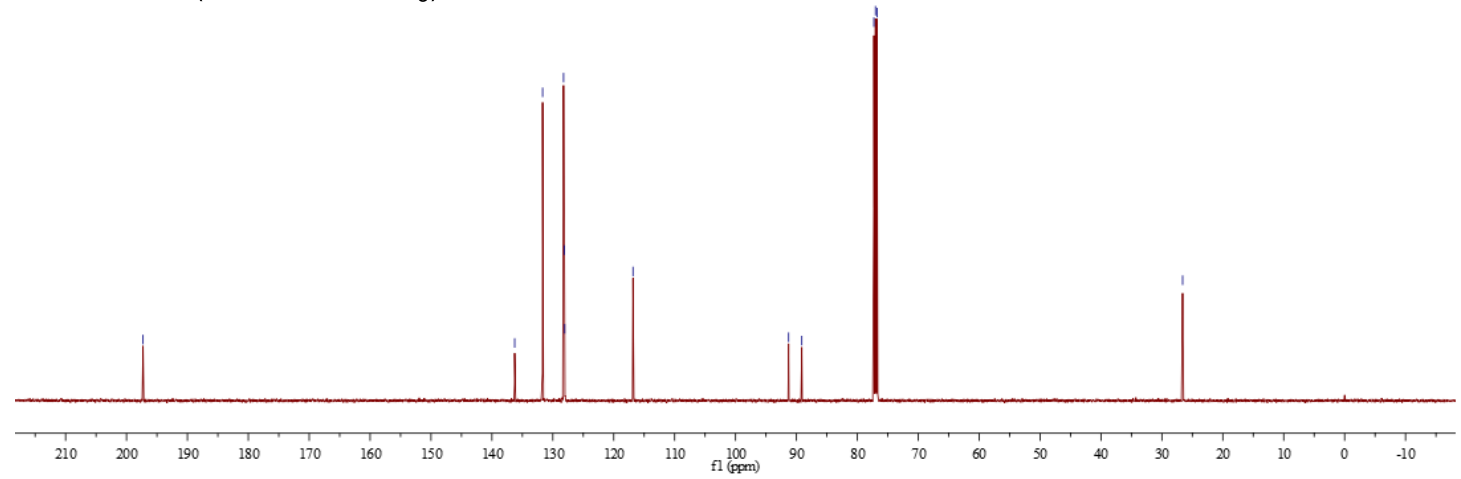


4-(But-3-en-1-yn-1-yl)- $N, N$-dimethylbenzamide (3i)
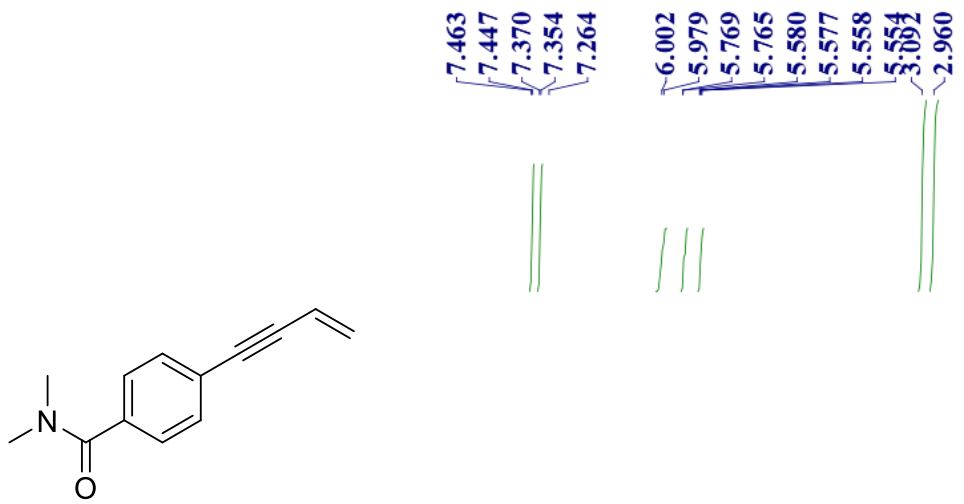

${ }^{1} \mathrm{H} \mathrm{NMR}\left(500 \mathrm{MHz}, \mathrm{CDCl}_{3}\right)$

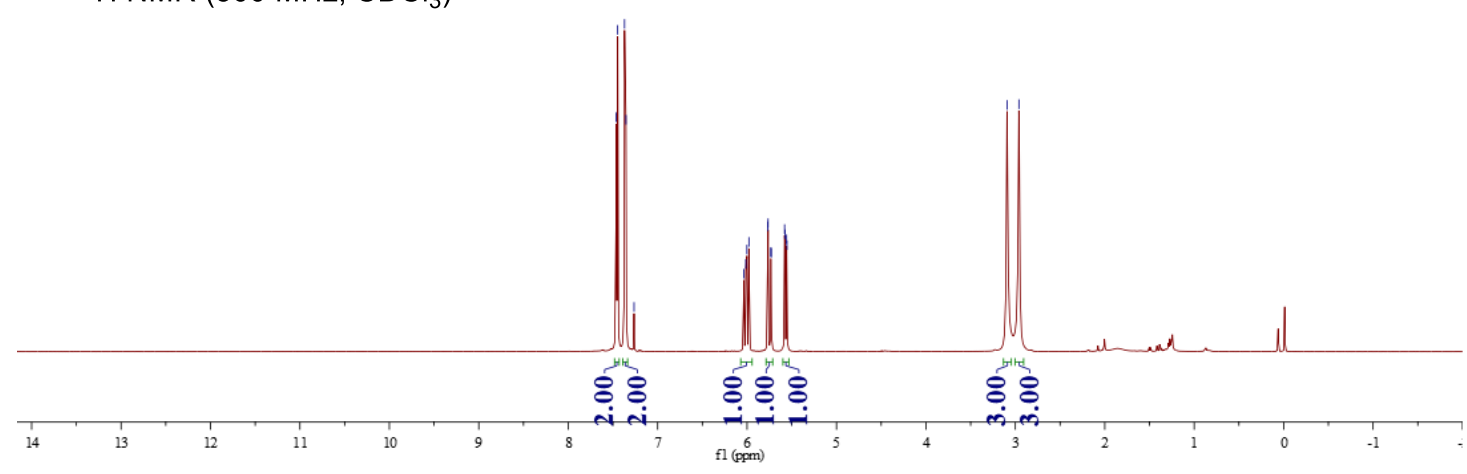

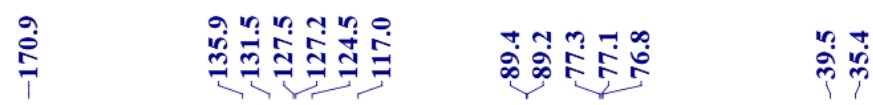
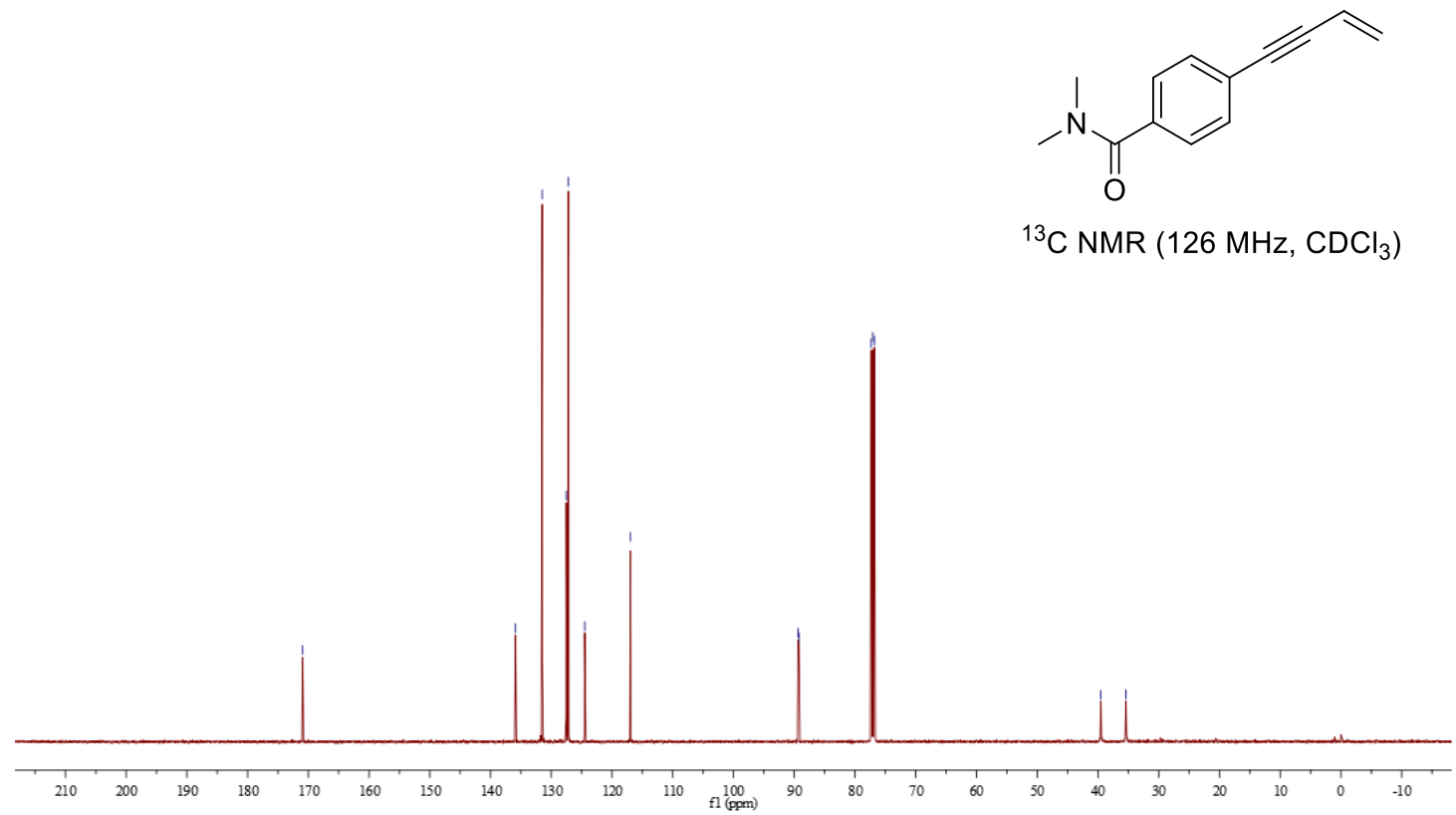

${ }^{3} \mathrm{C}$ NMR $\left(126 \mathrm{MHz}, \mathrm{CDCl}_{3}\right)$ 
4-(But-3-en-1-yn-1-yl)-1,1'-biphenyl (3j)

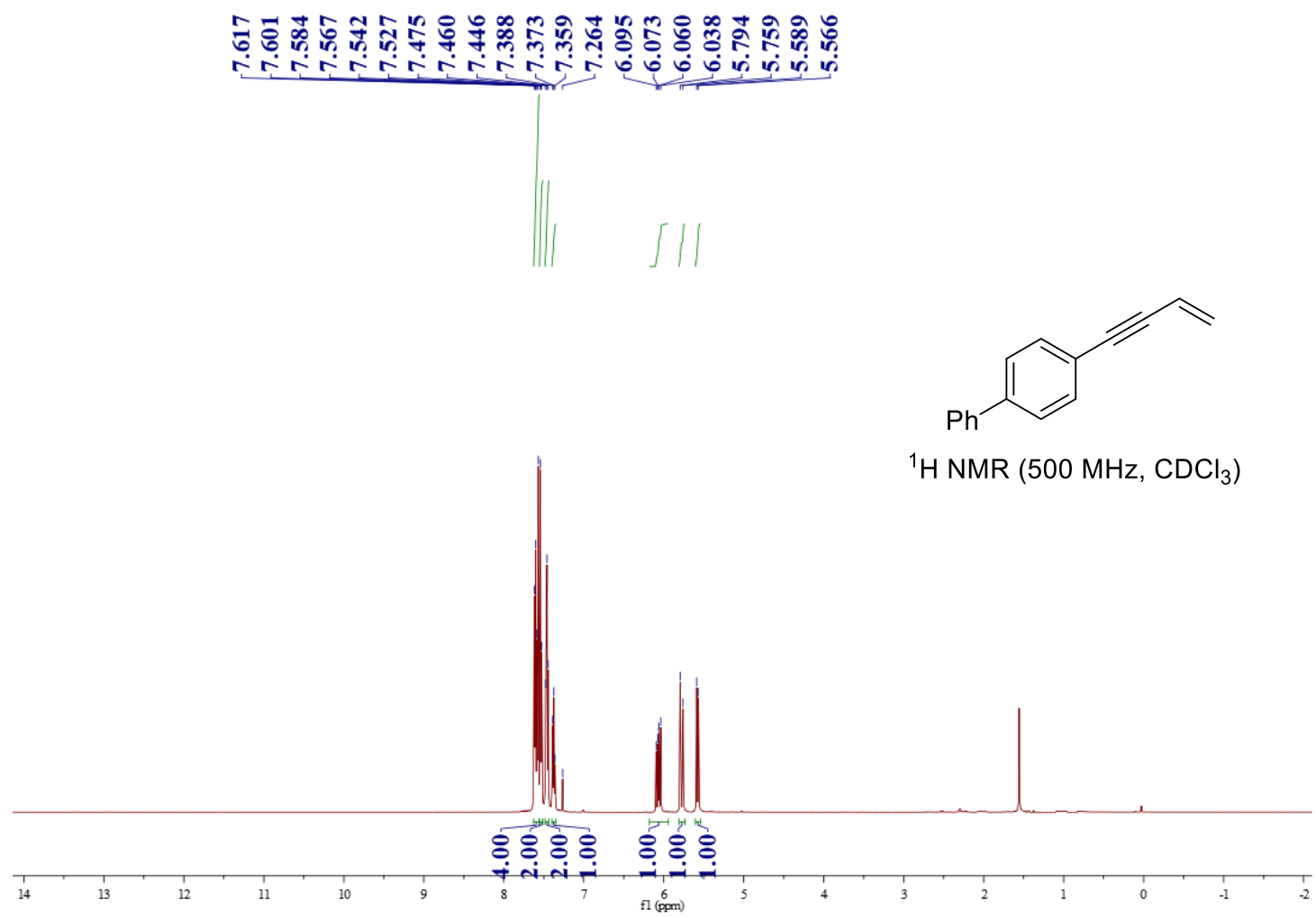

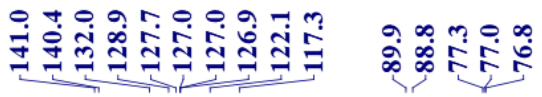

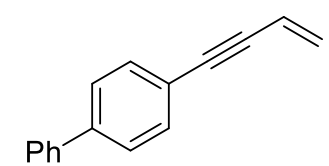

${ }^{13} \mathrm{C}$ NMR $\left(126 \mathrm{MHz}, \mathrm{CDCl}_{3}\right)$

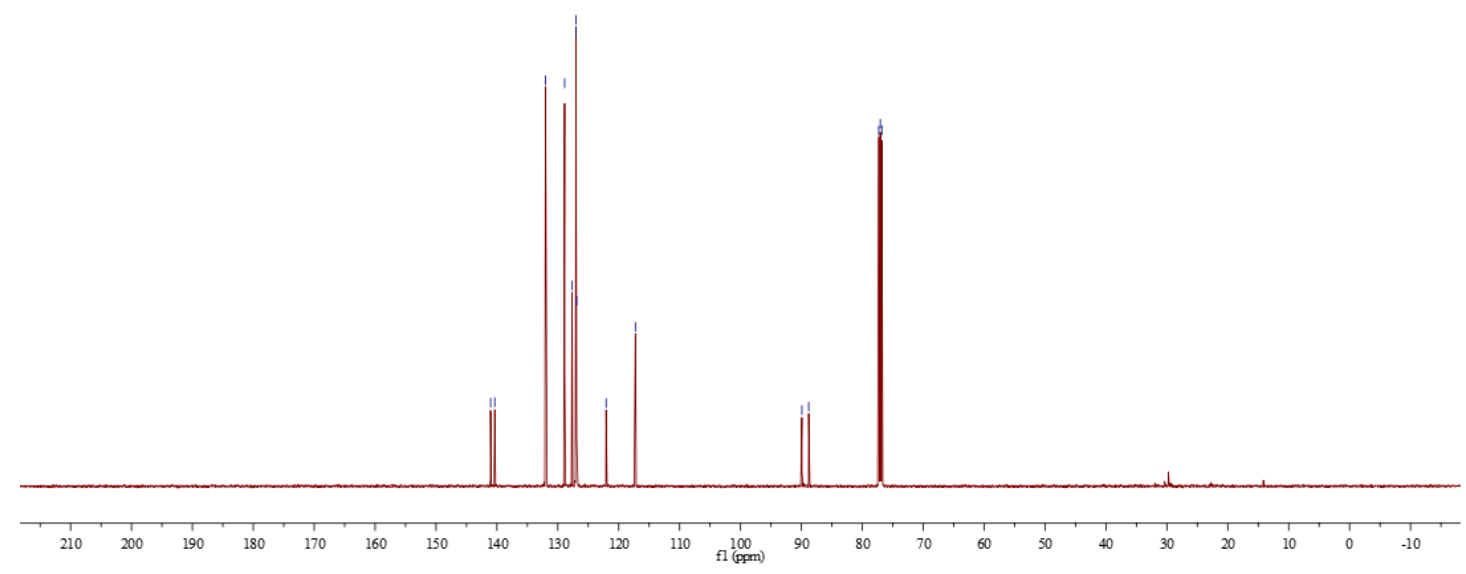


1-(But-3-en-1-yn-1-yl)-3-fluorobenzene (3k)
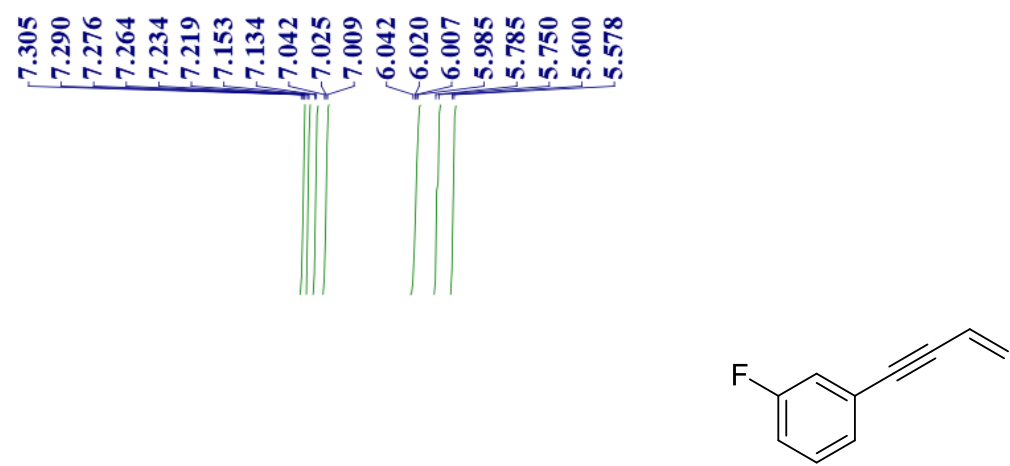

${ }^{1} \mathrm{H} \mathrm{NMR}\left(500 \mathrm{MHz}, \mathrm{CDCl}_{3}\right)$

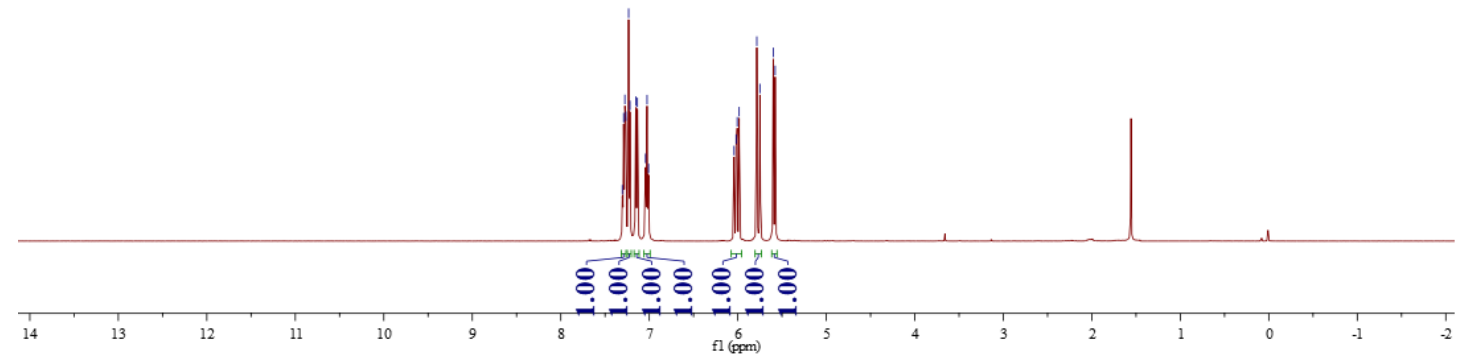

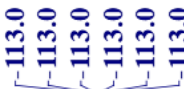

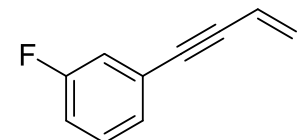

${ }^{19} \mathrm{~F}$ NMR $\left(471 \mathrm{MHz}, \mathrm{CDCl}_{3}\right)$ 


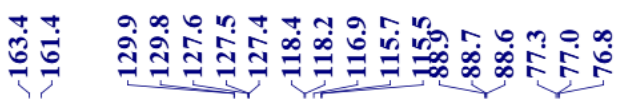

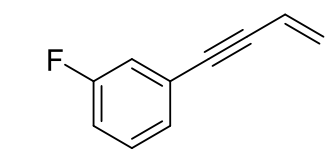

${ }^{13} \mathrm{C}$ NMR $\left(126 \mathrm{MHz}, \mathrm{CDCl}_{3}\right)$

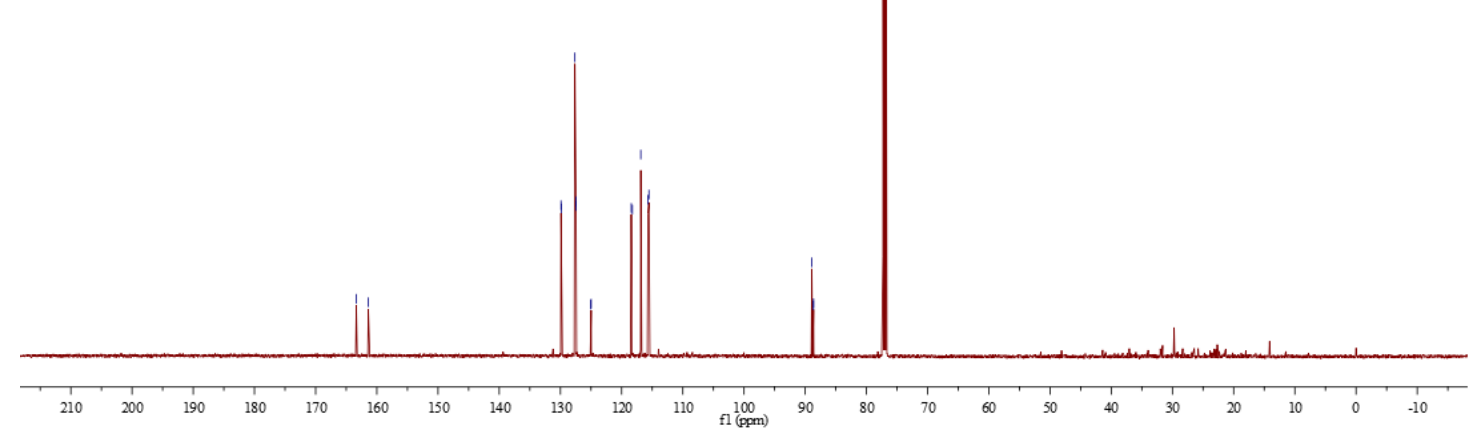

Methyl 2-(but-3-en-1-yn-1-yl)benzoate (3I)

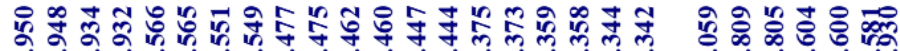

مी

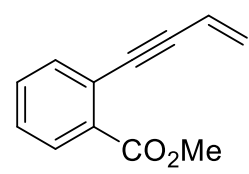

${ }^{1} \mathrm{H}$ NMR $\left(500 \mathrm{MHz}, \mathrm{CDCl}_{3}\right)$

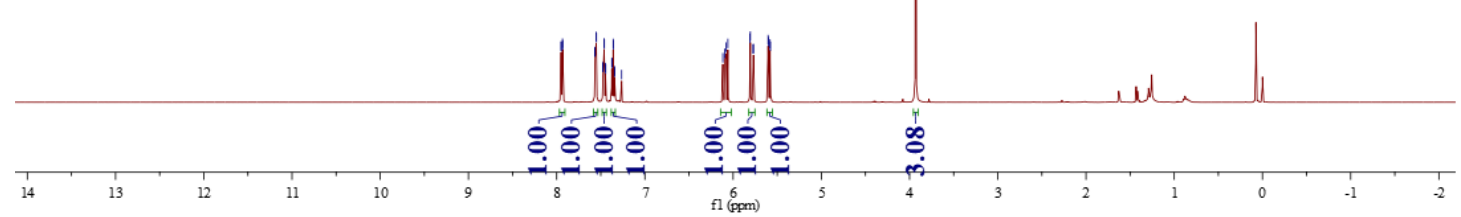




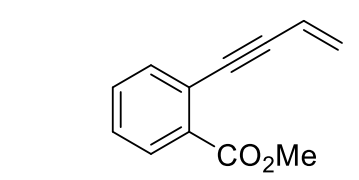

${ }^{13} \mathrm{C}$ NMR (126 MHz, $\mathrm{CDCl}_{3}$ )

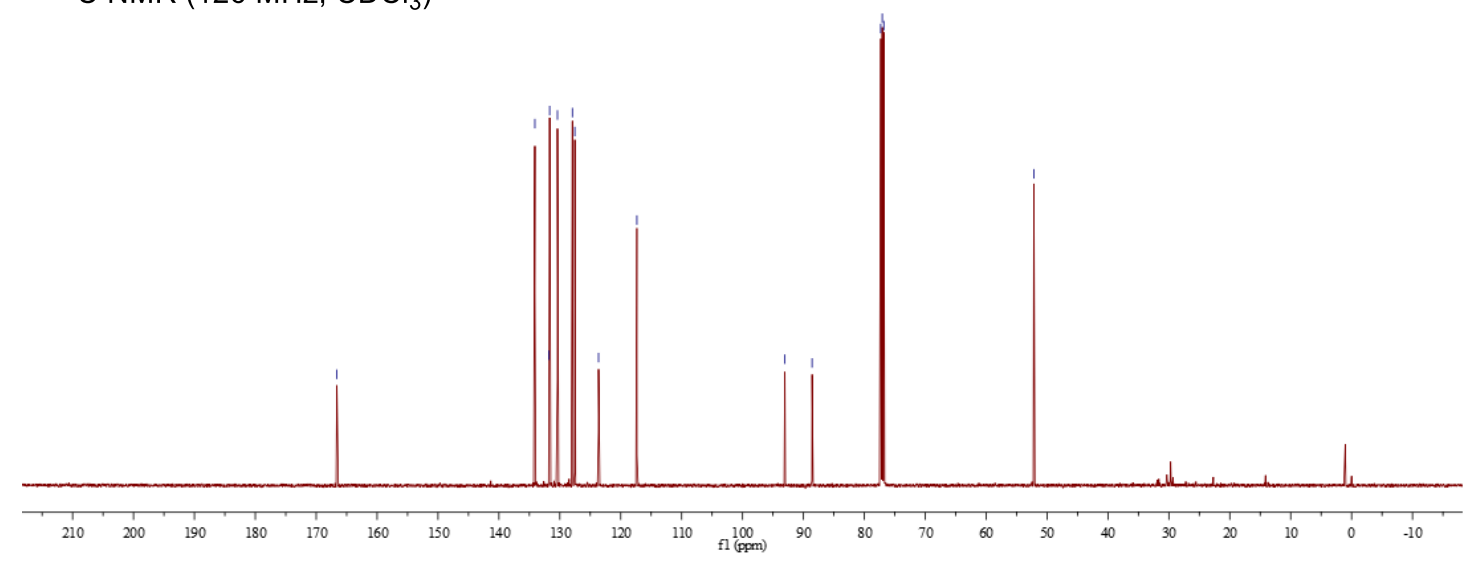

1-(But-3-en-1-yn-1-yl)-4-ethoxybenzene (3m)
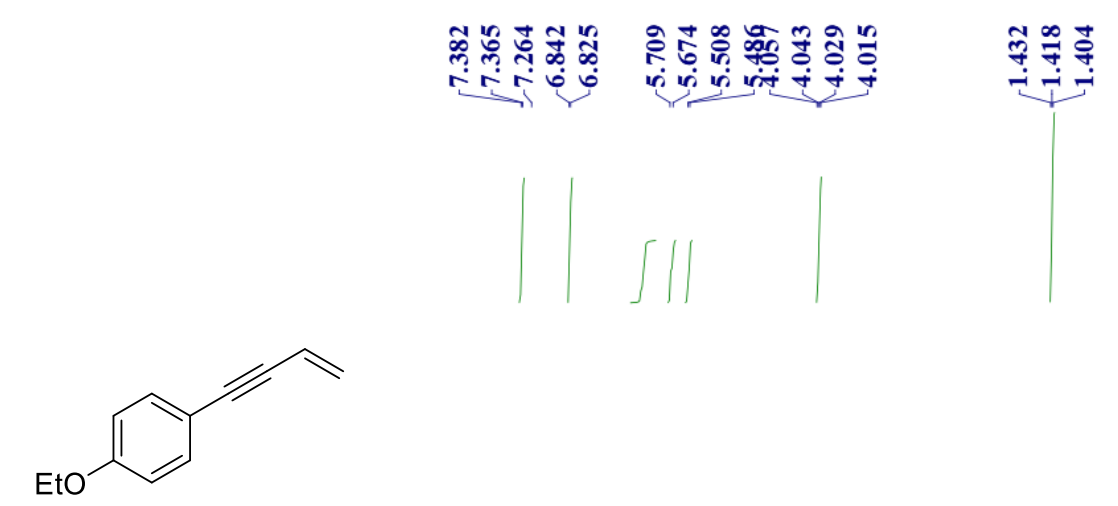

${ }^{1} \mathrm{H} \mathrm{NMR}\left(500 \mathrm{MHz}, \mathrm{CDCl}_{3}\right)$

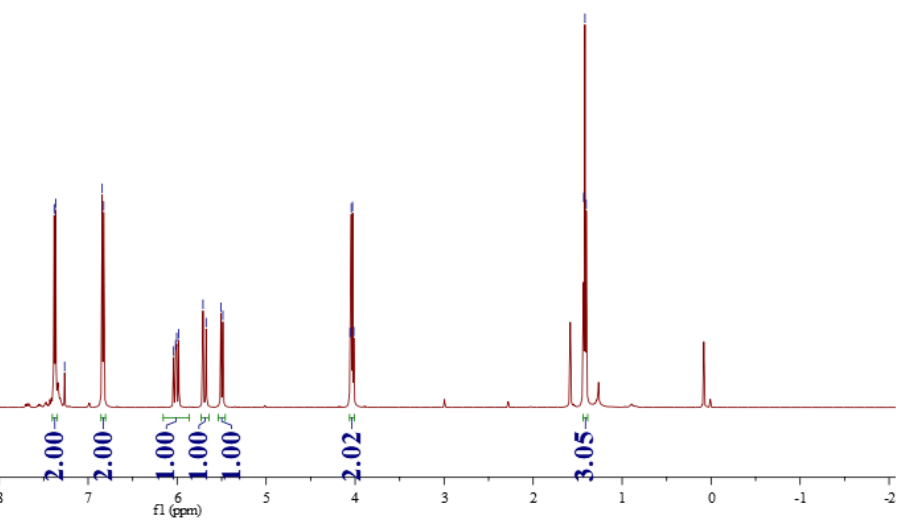



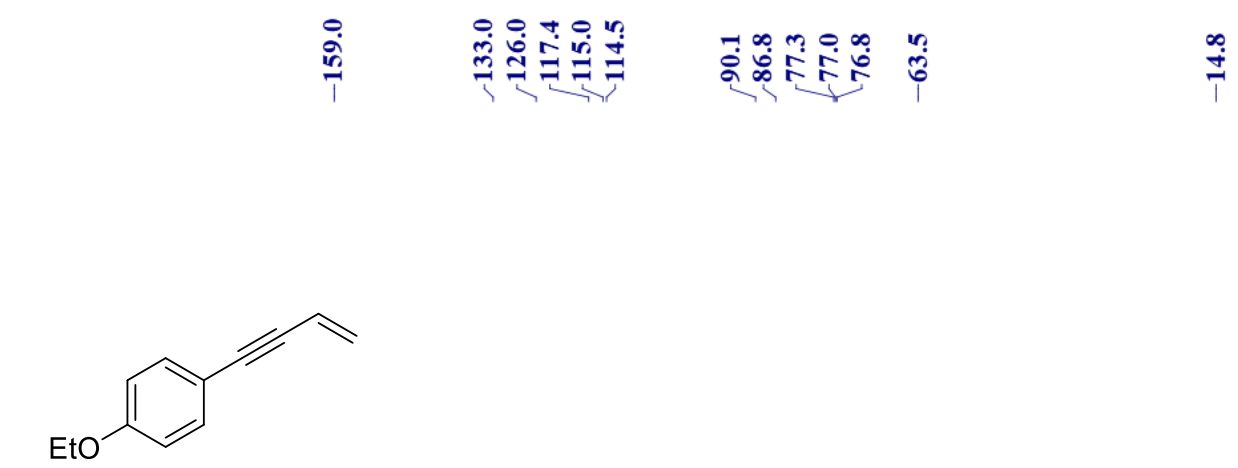

${ }^{13} \mathrm{C} \mathrm{NMR}\left(126 \mathrm{MHz}, \mathrm{CDCl}_{3}\right)$

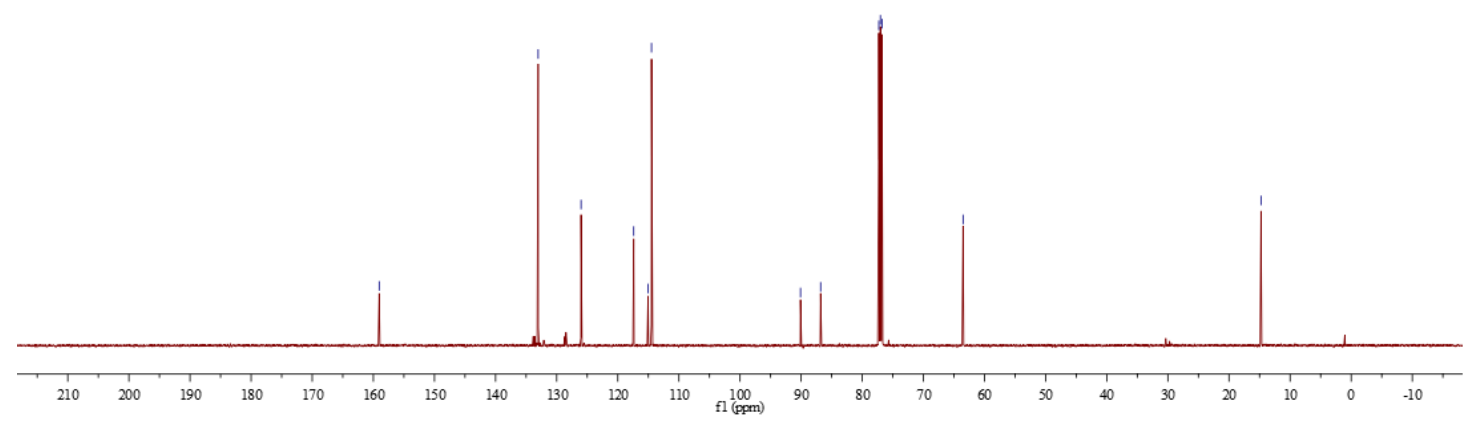

1-(But-3-en-1-yn-1-yl)-3-methoxybenzene (3n)

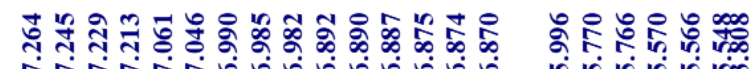

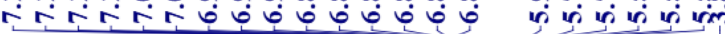

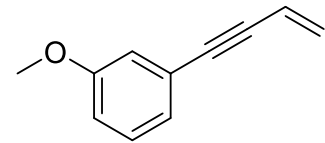

${ }^{1} \mathrm{H} \mathrm{NMR}\left(500 \mathrm{MHz}, \mathrm{CDCl}_{3}\right)$

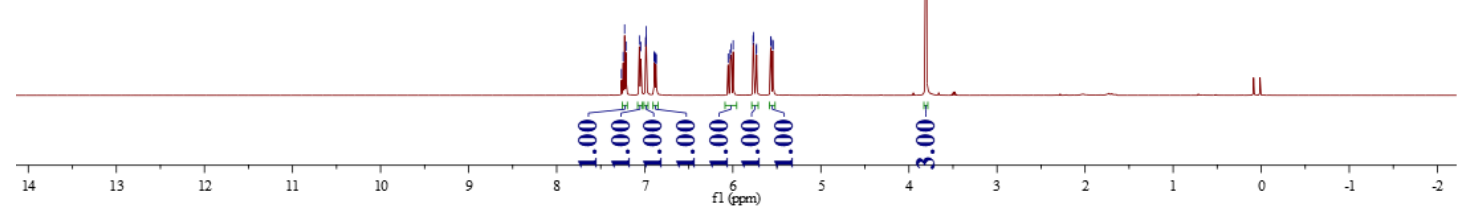




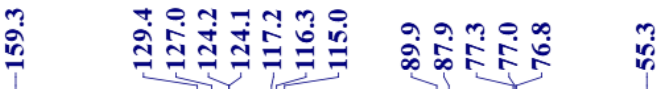

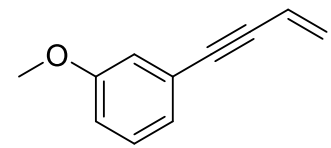

${ }^{13} \mathrm{C}$ NMR $\left(126 \mathrm{MHz}, \mathrm{CDCl}_{3}\right)$

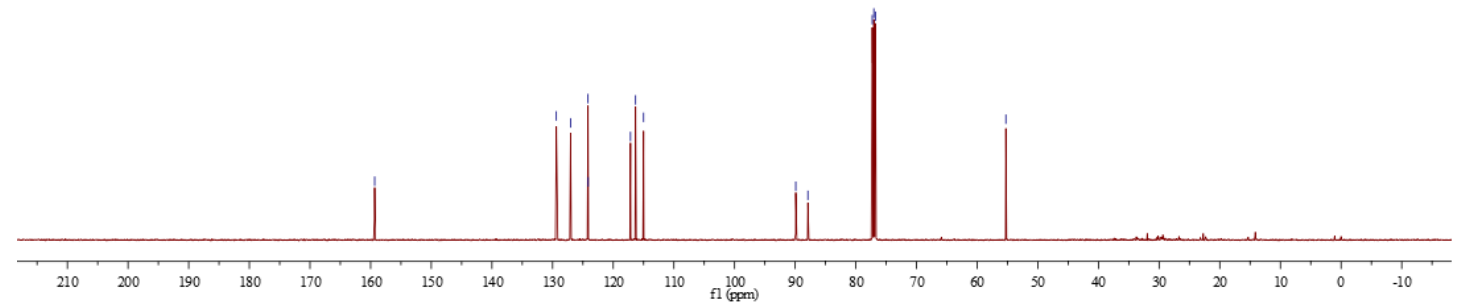

1-(But-3-en-1-yn-1-yl)-2-methoxybenzene (3o)

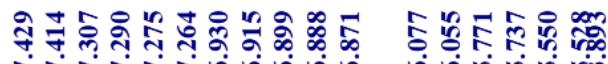

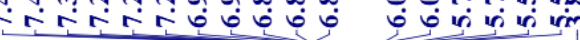
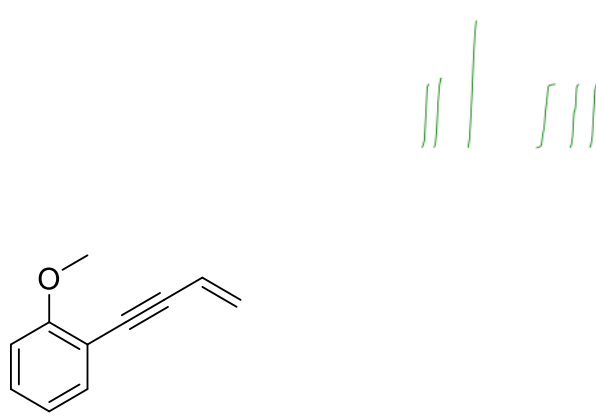

${ }^{1} \mathrm{H}$ NMR $\left(500 \mathrm{MHz}, \mathrm{CDCl}_{3}\right)$

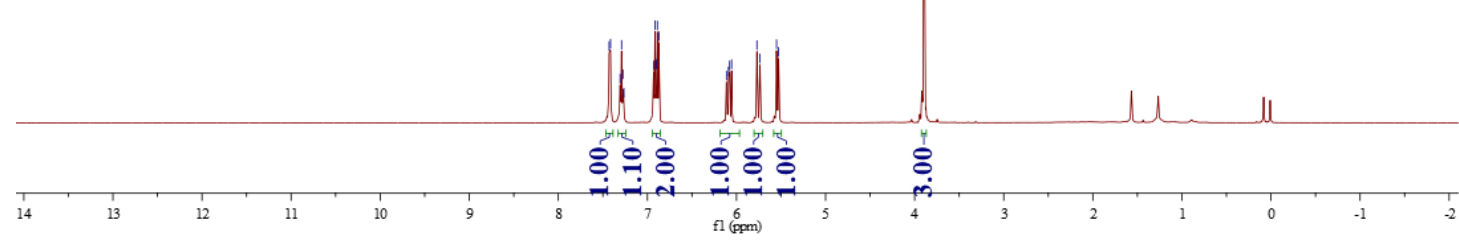




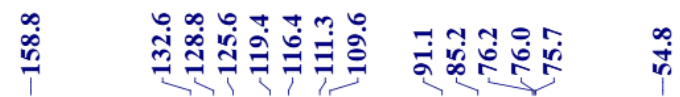

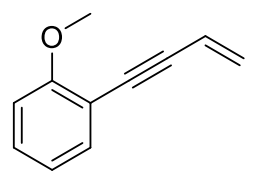

${ }^{13} \mathrm{C} \mathrm{NMR}\left(126 \mathrm{MHz}, \mathrm{CDCl}_{3}\right)$

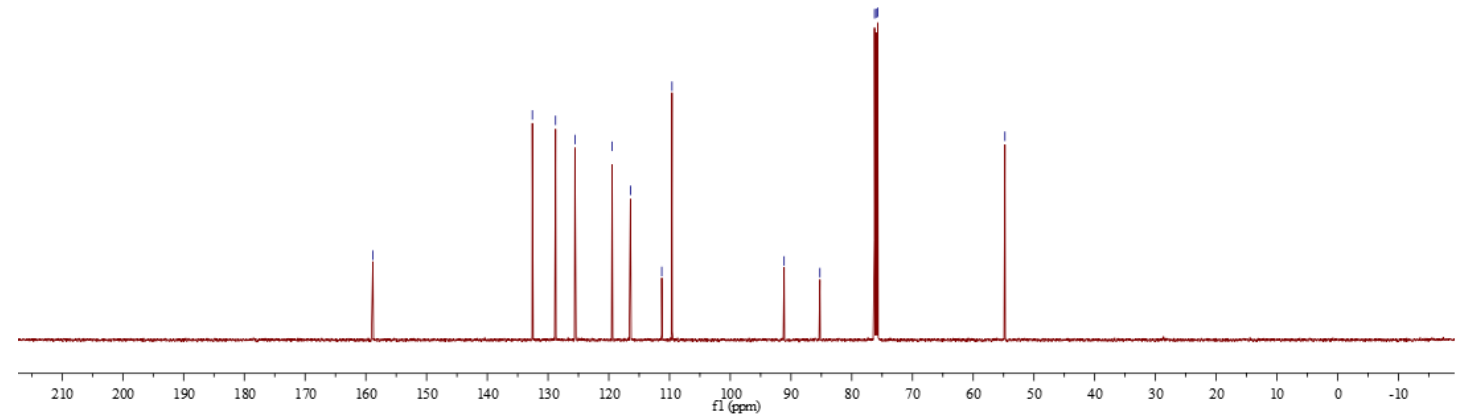

1-(But-3-en-1-yn-1-yl)-2-ethylbenzene (3p)

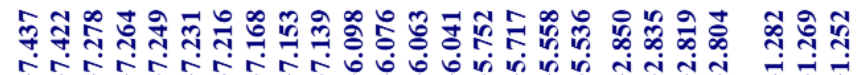

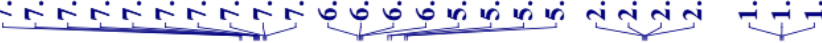

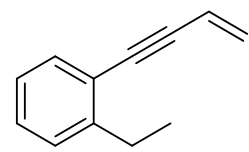

${ }^{1} \mathrm{H}$ NMR $\left(500 \mathrm{MHz}, \mathrm{CDCl}_{3}\right)$

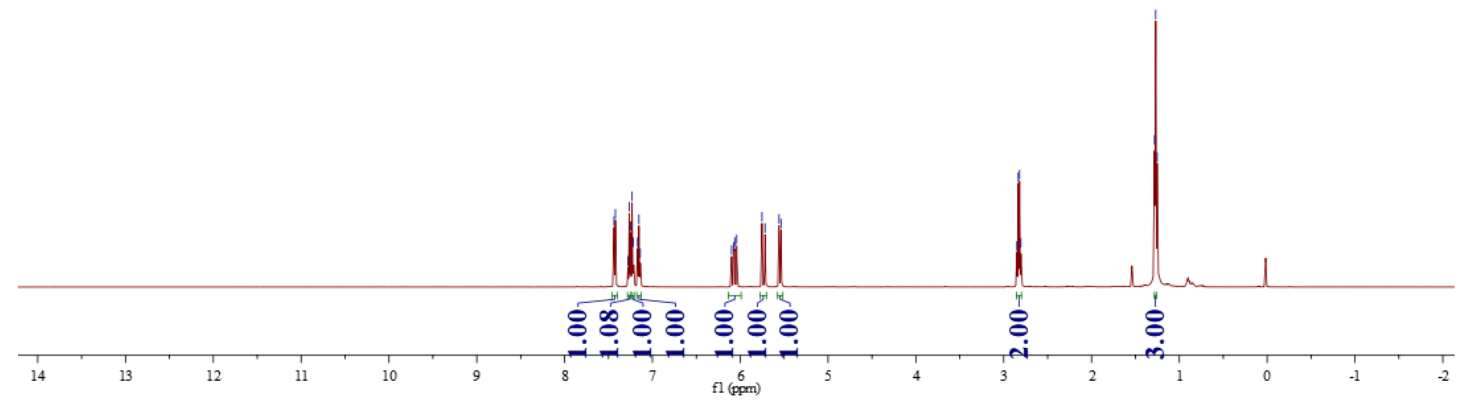




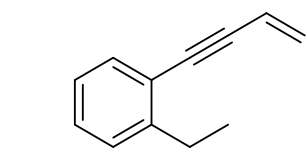

${ }^{13} \mathrm{C} \mathrm{NMR}\left(126 \mathrm{MHz}, \mathrm{CDCl}_{3}\right)$

3-(But-3-en-1-yn-1-yl)thiophene (3q)

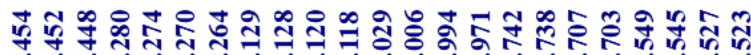

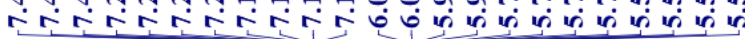
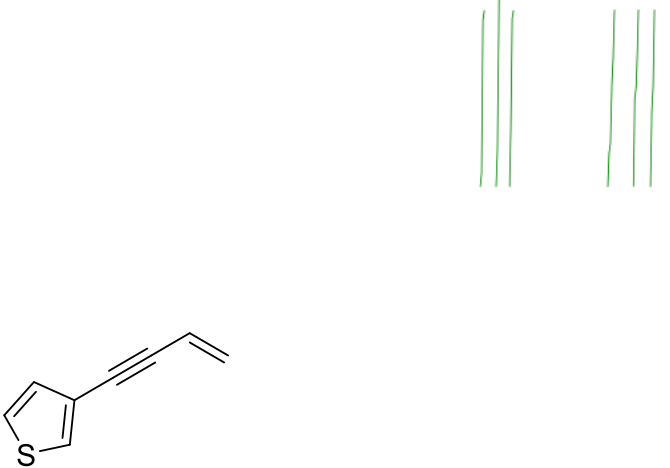

${ }^{1} \mathrm{H} \mathrm{NMR}\left(500 \mathrm{MHz}, \mathrm{CDCl}_{3}\right)$

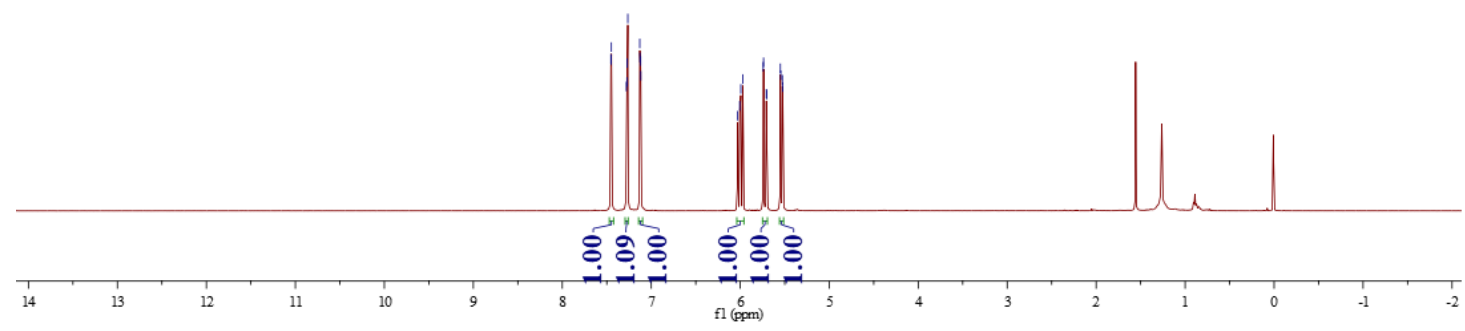




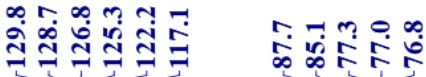

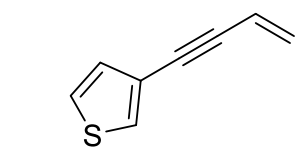

${ }^{13} \mathrm{C} \mathrm{NMR}\left(126 \mathrm{MHz}, \mathrm{CDCl}_{3}\right)$

6-(But-3-en-1-yn-1-yl)-4,4-dimethylthiochromane (3r)

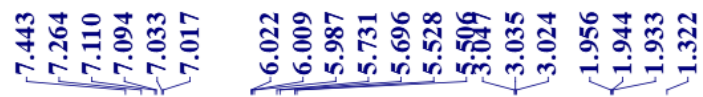

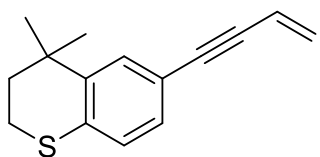

${ }^{1} \mathrm{H}$ NMR $\left(500 \mathrm{MHz}, \mathrm{CDCl}_{3}\right)$

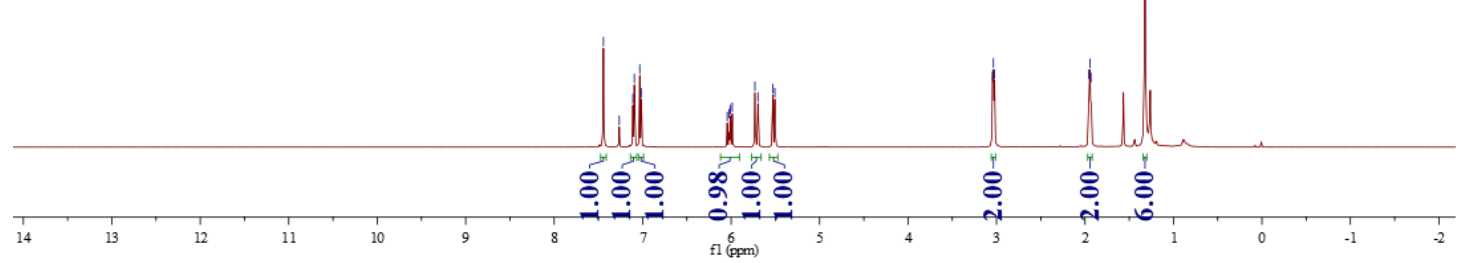




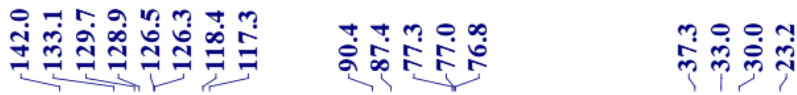

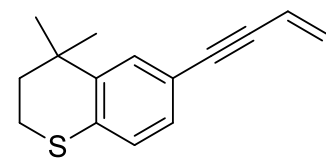

${ }^{13} \mathrm{C} \mathrm{NMR}\left(126 \mathrm{MHz}, \mathrm{CDCl}_{3}\right)$

3-(But-3-en-1-yn-1-yl)-1-tosyl-1H-indole (3s)

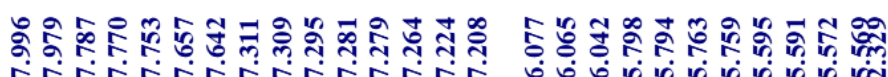

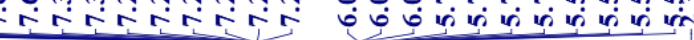
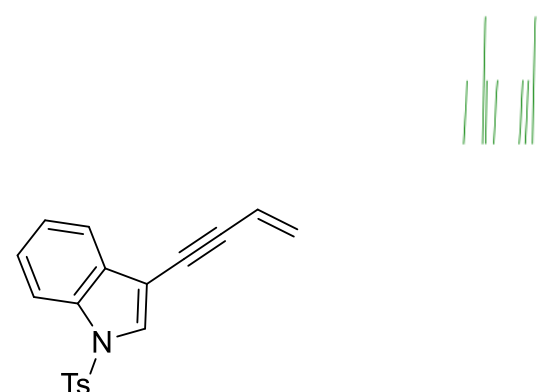

${ }^{1} \mathrm{H}$ NMR $\left(500 \mathrm{MHz}, \mathrm{CDCl}_{3}\right)$

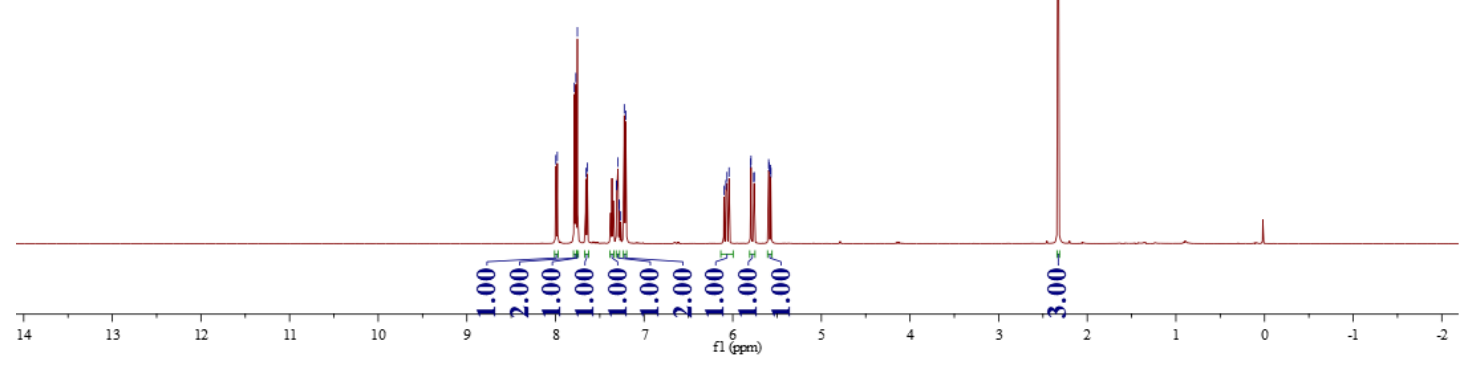




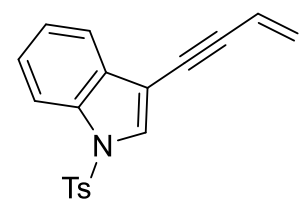

${ }^{13} \mathrm{C}$ NMR $\left(126 \mathrm{MHz}, \mathrm{CDCl}_{3}\right)$

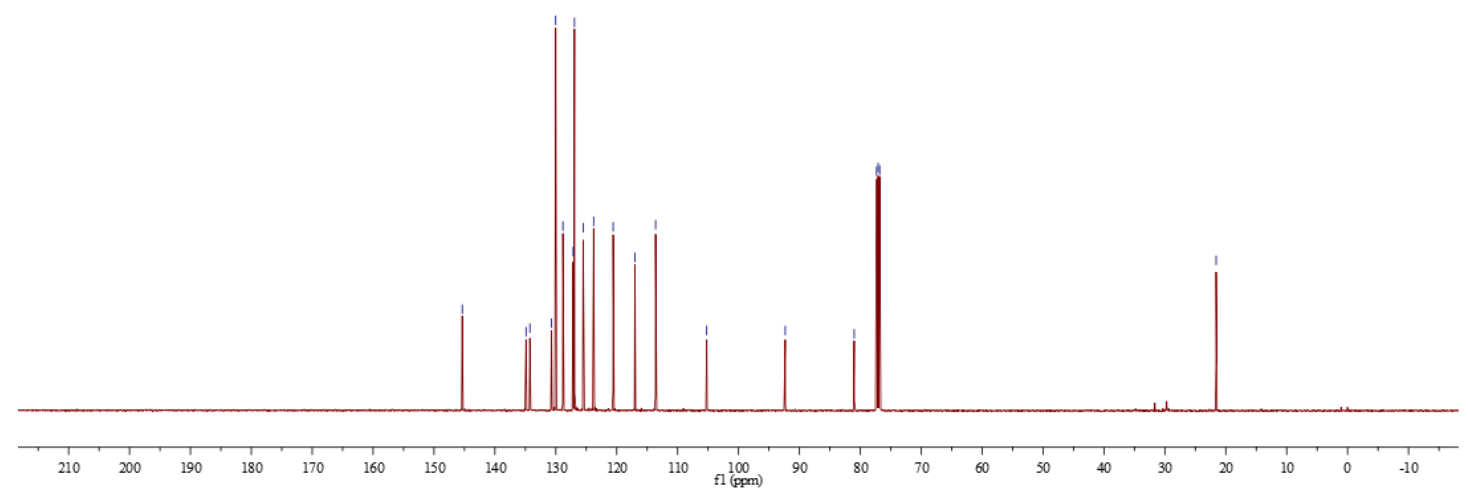

(Bent-4-en-2-yn-1-yloxy)benzene (3t)
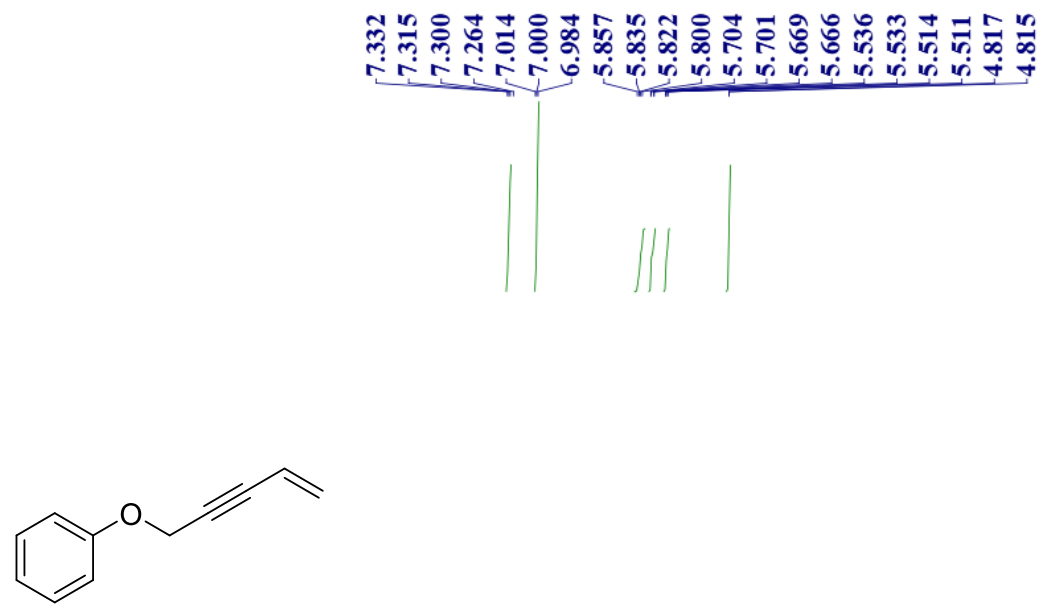

${ }^{1} \mathrm{H}$ NMR $\left(500 \mathrm{MHz}, \mathrm{CDCl}_{3}\right)$

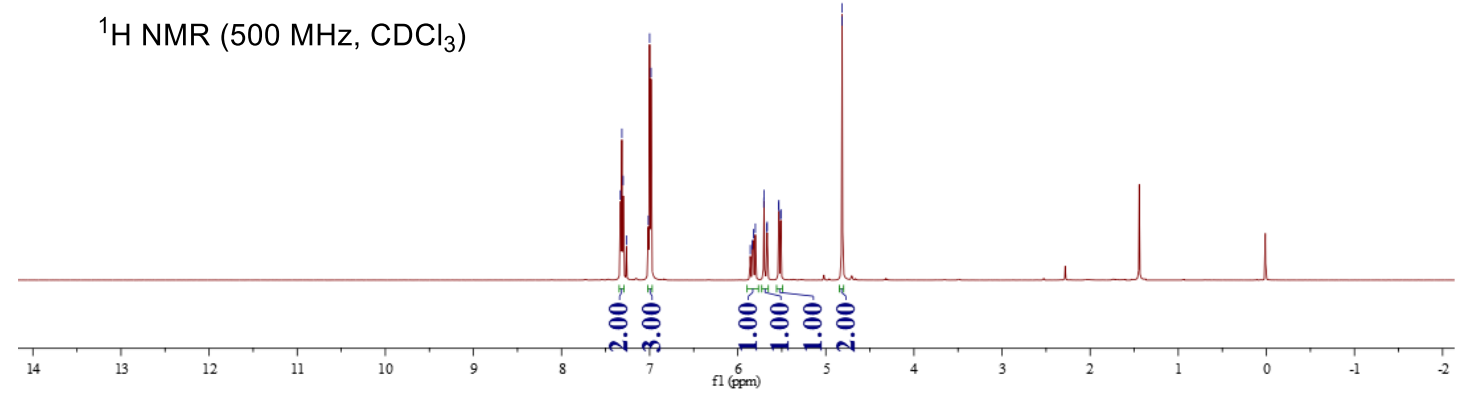




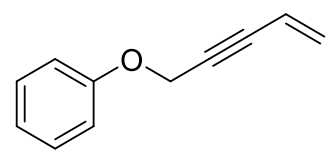

$\left.{ }^{13} \mathrm{C} \mathrm{NMR} \mathrm{(126} \mathrm{MHz,} \mathrm{CDCl}_{3}\right)$

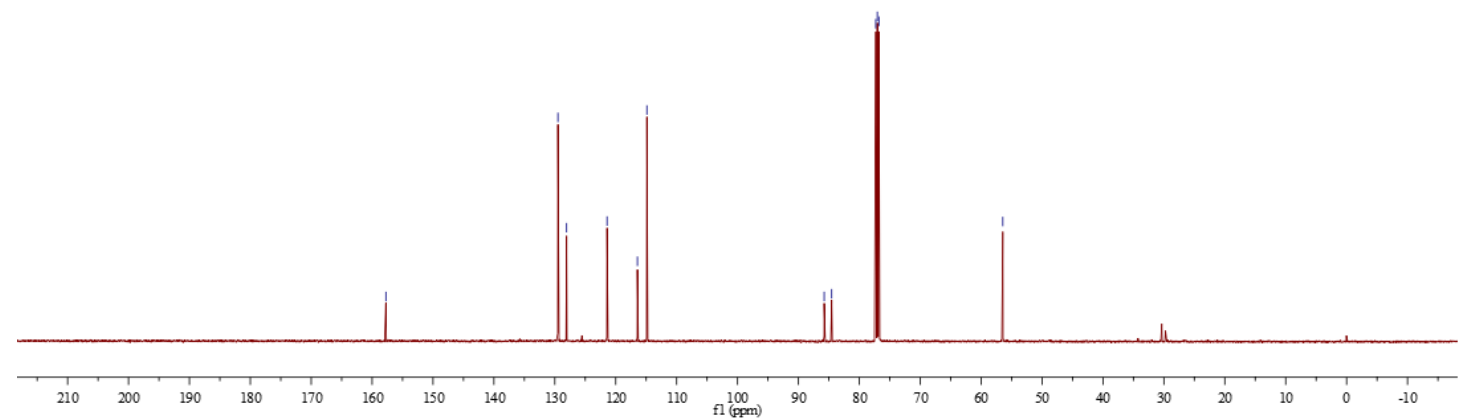

Bent-4-en-2-yn-1-yl benzoate (3u)

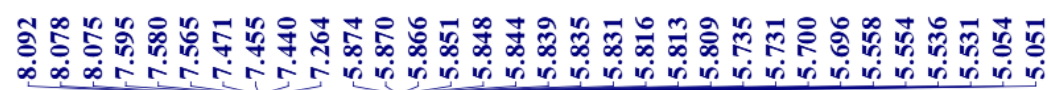
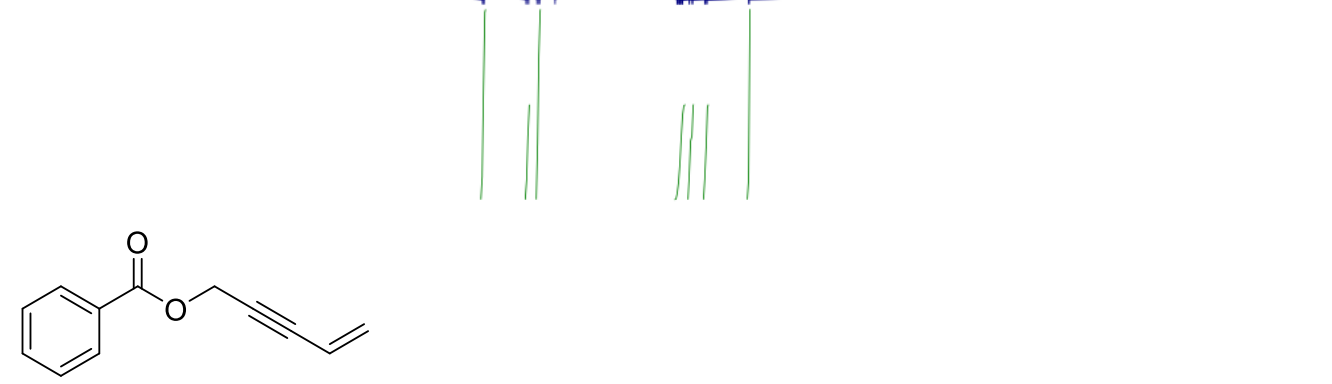

${ }^{1} \mathrm{H} \mathrm{NMR}\left(500 \mathrm{MHz}, \mathrm{CDCl}_{3}\right)$

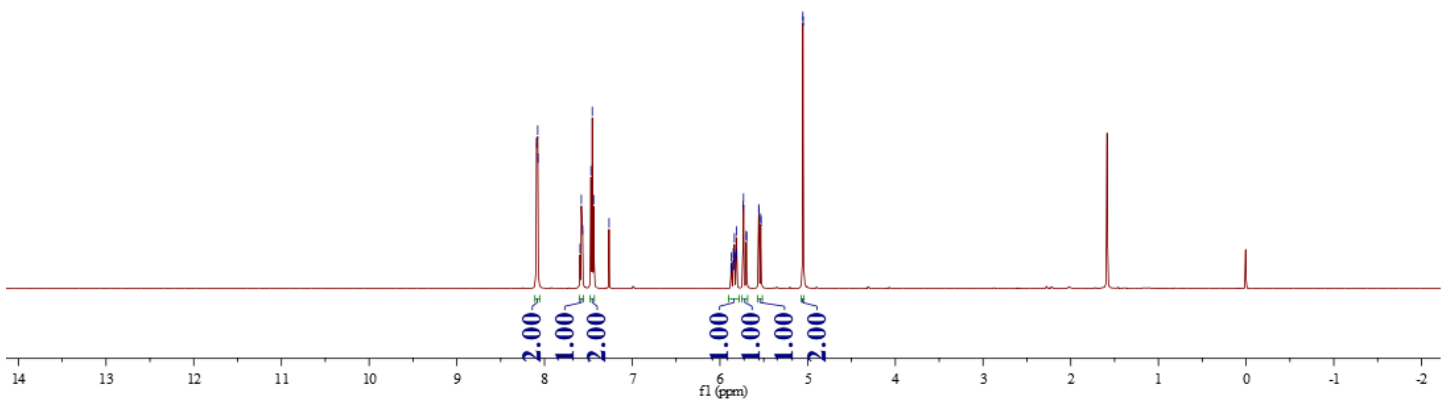




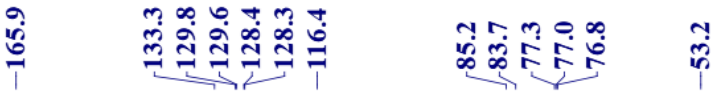

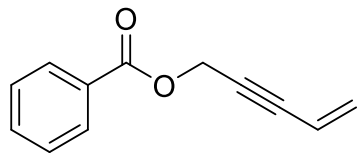

${ }^{13} \mathrm{C}$ NMR $\left(126 \mathrm{MHz}, \mathrm{CDCl}_{3}\right)$

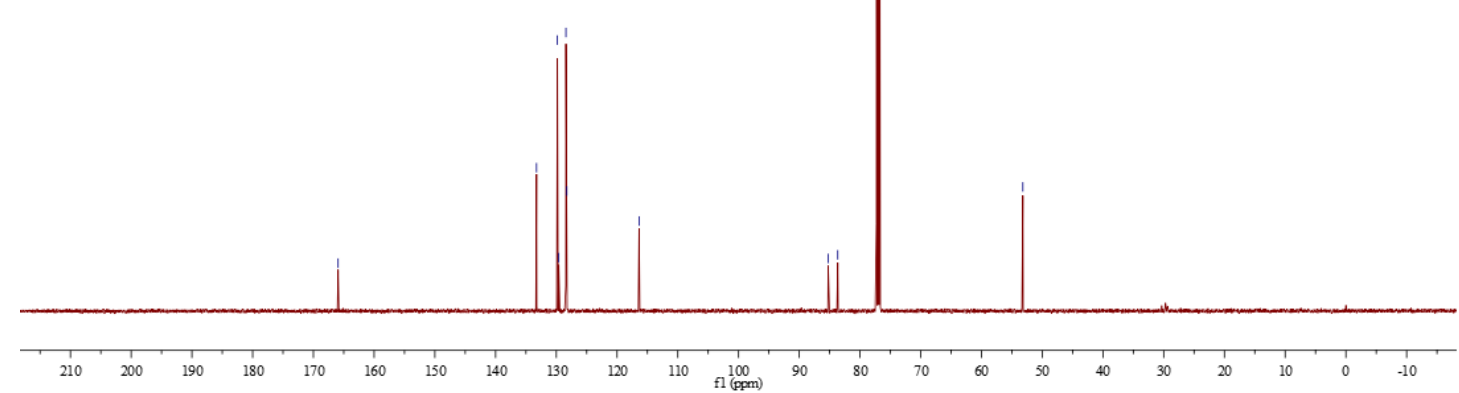

4-(Hex-5-en-3-yn-1-yl)benzonitrile (3v)
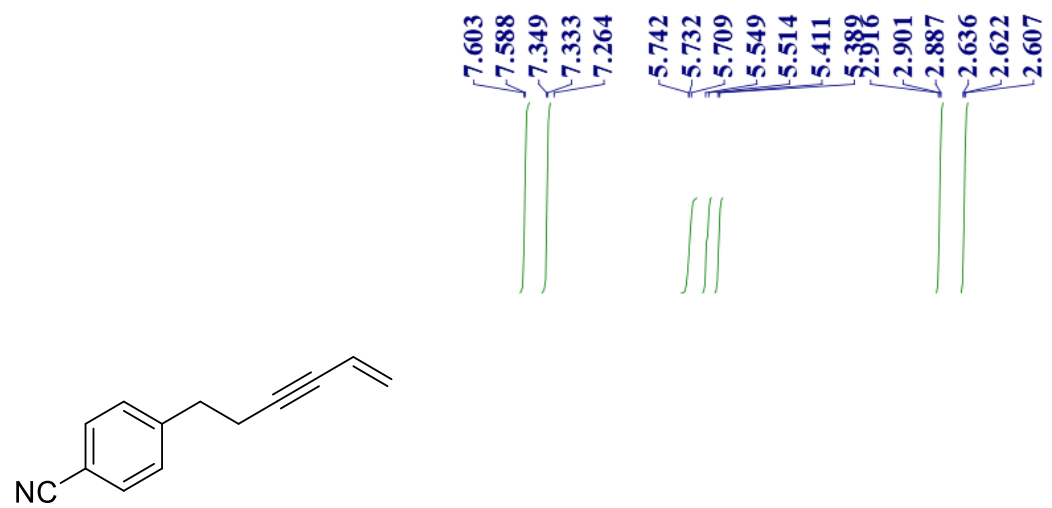

${ }^{1} \mathrm{H}$ NMR $\left(500 \mathrm{MHz}, \mathrm{CDCl}_{3}\right)$

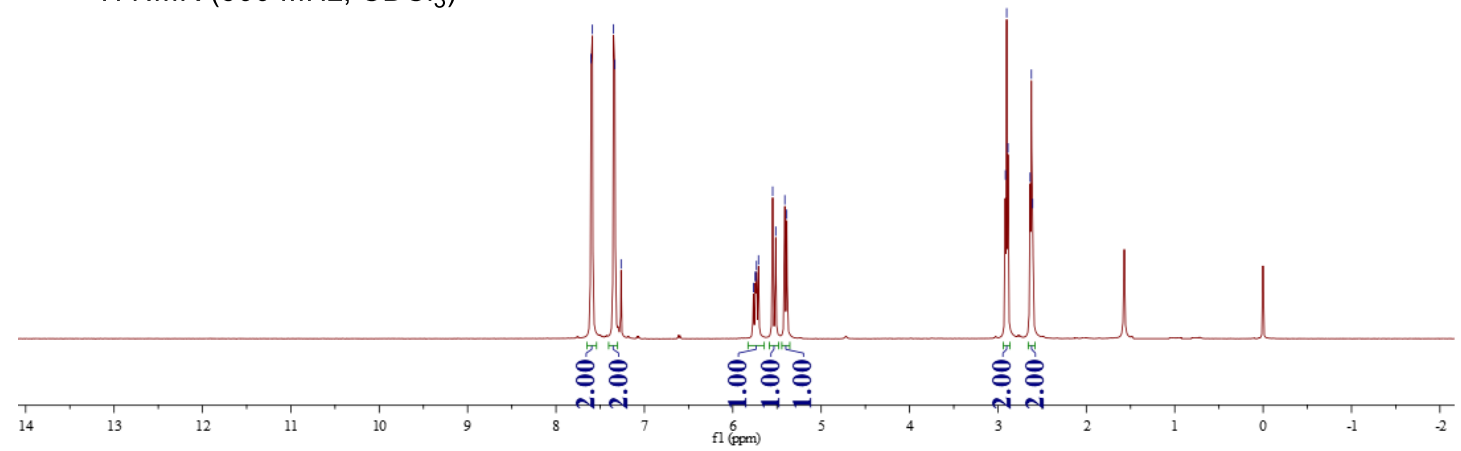




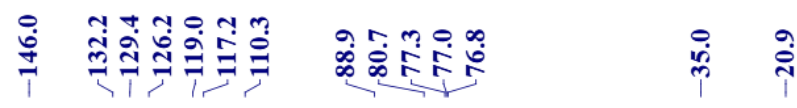

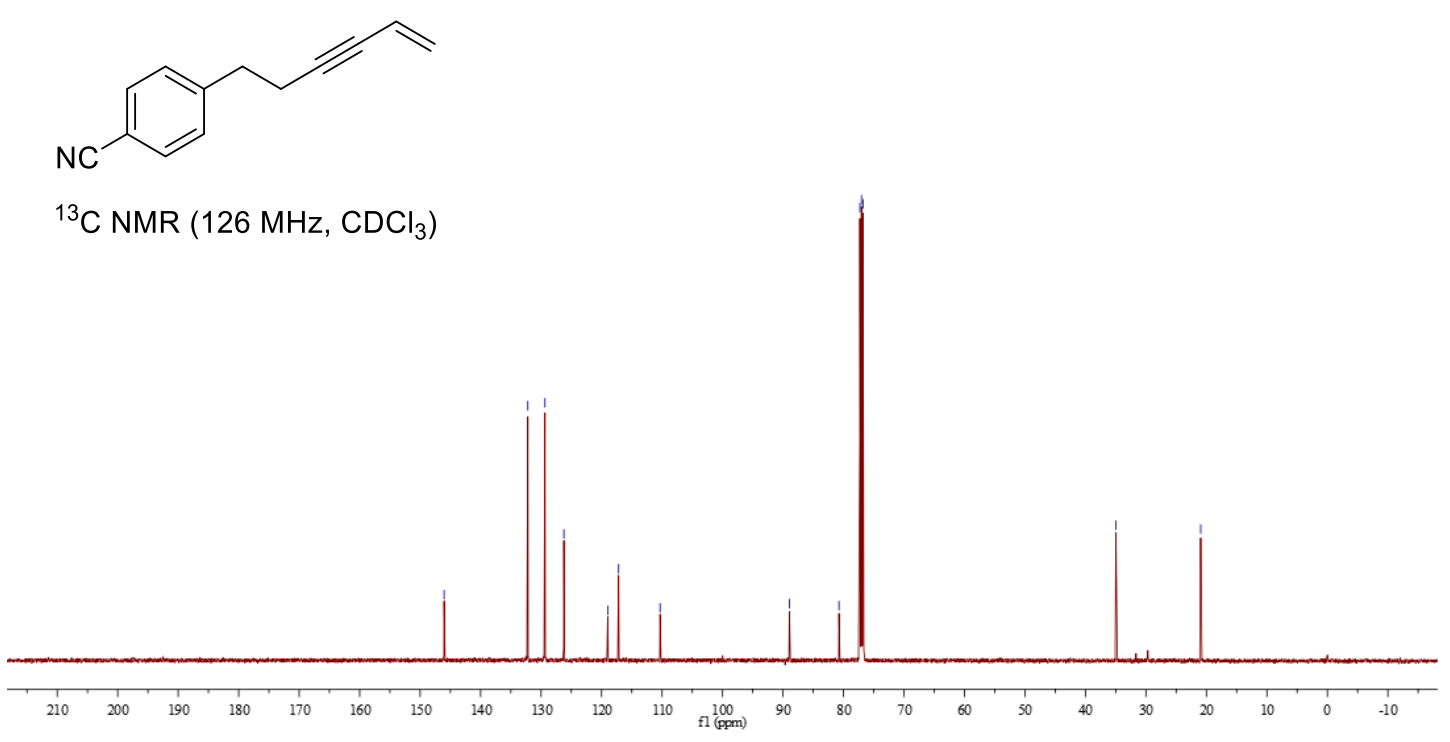

$N$-benzyl- $N$-methylpent-4-en-2-yn-1-amine (3w)
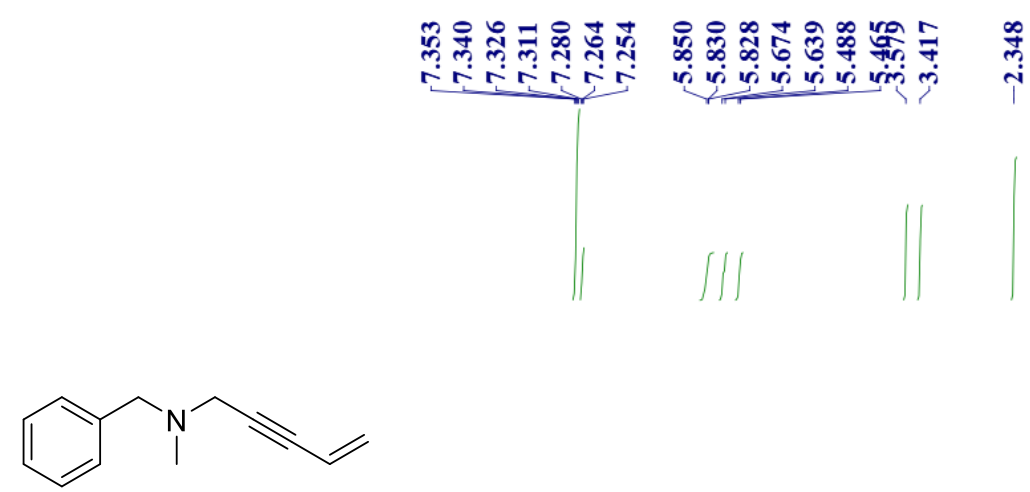

${ }^{1} \mathrm{H} \mathrm{NMR}\left(500 \mathrm{MHz}, \mathrm{CDCl}_{3}\right)$

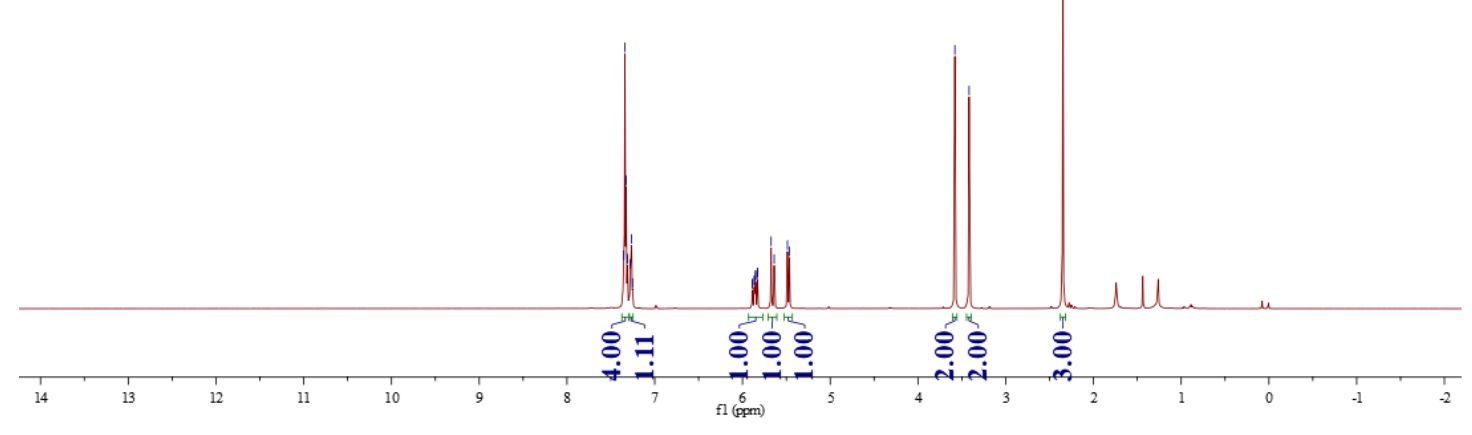




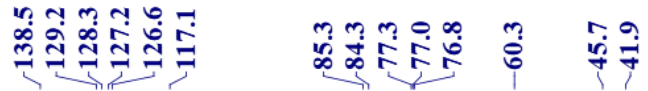

$\mathrm{N}$

${ }^{13} \mathrm{C} \mathrm{NMR} \mathrm{(126} \mathrm{MHz,} \mathrm{CDCl}_{3}$ )

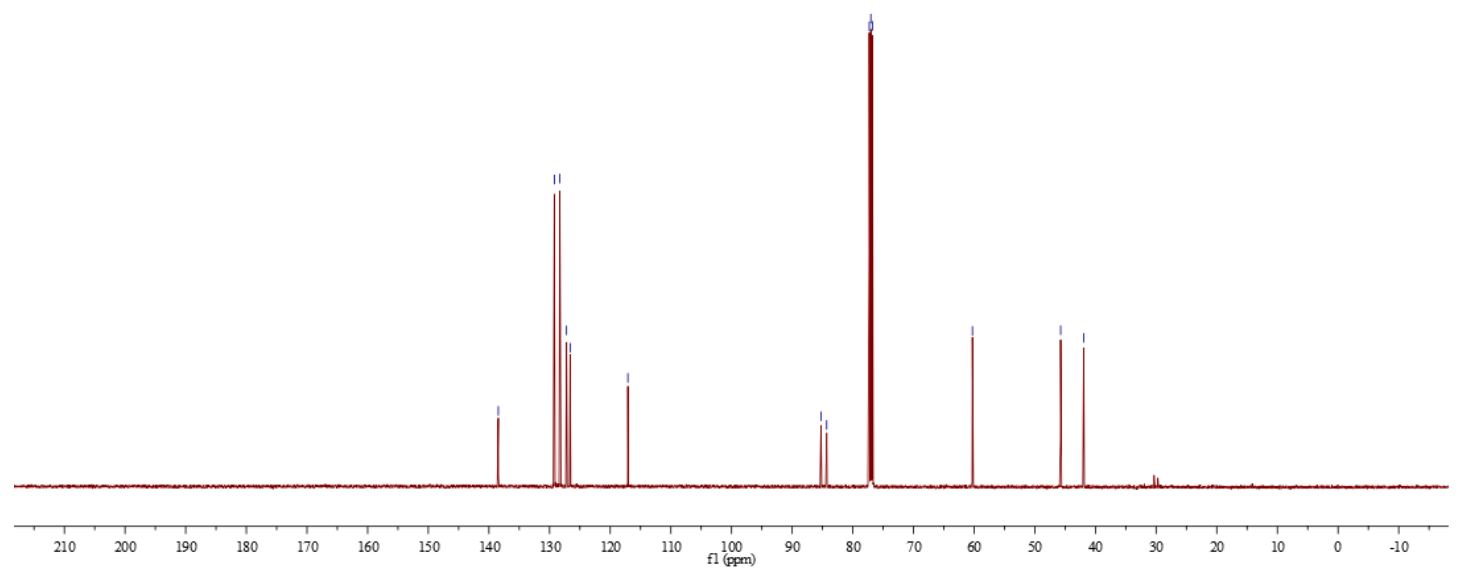

